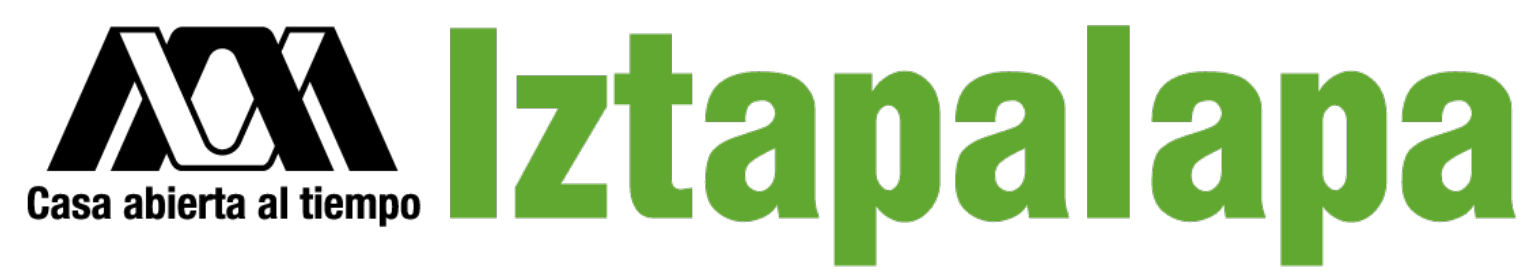

\title{
POBRES LABORIOSOS
}

Una genealogía del trabajo en el dispositivo liberal.

TESIS QUE PRESENTA

JOSÉ RICARDO BERNAL LUGO

PARA OBTENER EL GRADO DE DOCTOR EN HUMANIDADES

(FILOSOFÍA MORAL Y POLÍTICA)

DIRECTOR: DR. SERGIO PÉREZ CORTÉS

JURADO: DR. DÓNOVAN HERNÁNDEZ CASTELLANOS

JURADO: DRA. NORMA HORTENSIA HERNÁNDEZ GARCÍA

CIUDAD DE MÉXICO, DICIEMBRE 2016. 


\section{Índice}

Introducción. ..............................................................

I.- 1848: La disputa por el trabajo...................................... 15

1.1 La herencia de la fraternidad en la I República........................................16

1.2 Fraternidad y derecho al trabajo en la II República..................................28

1.3 Adiós al derecho al trabajo: la derrota de la República social..........................45

II.- El trabajo en el dispositivo liberal....................................53

2.1 El liberalismo: una realidad del siglo XIX ..................................... 54

2.2 El lugar del mercado en el dispositivo liberal......................................68

2.3 La propiedad privada y el mercado en el dispositivo liberal...........................87

2.4 Pobres laboriosos...............................................................

2.5 Libertad de trabajo.......................................................... 101

2.6 Beneficencia y derecho al trabajo ........................................ 120

III.- Del trabajo como algo más que una mercancía al hombre empresa.............135

3.1 Desplazamientos del dispositivo liberal (Marx, Durkheim y Keynes).......................140

3.2 De cómo el siglo XX recuperó el dispositivo liberal......................................162

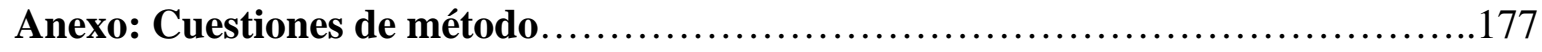

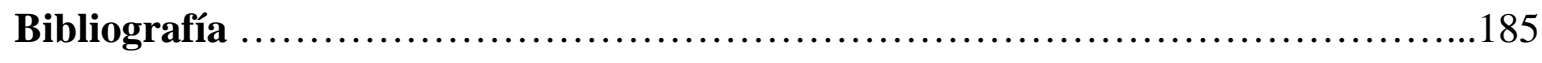


A Virgilio que siempre sale airoso de los infiernos 


\section{Agradecimientos}

Este trabajo de investigación sólo pudo ser posible gracias a una beca otorgada mediante el programa de becarios de excelencia de CONACYT. Quisiera expresar mi agradecimiento a los profesores Jesús Rodríguez Zepeda, Gustavo Leyva y Jorge Rendón por su constante apoyo durante los 6 años que estuve en el posgrado de Filosofía Moral y Política en la UAMIztapalapa. A mi asesor Sergio Pérez por sus siempre acertados comentarios y la concienzuda revisión de este trabajo. Al profesor Patrice Vermeren con quien tuve la oportunidad de realizar una estancia doctoral en Paris VIII y al profesor Diogo Sardinha cuya hospitalidad, apoyo y consejos tanto académicos como personales fueron esenciales el tiempo que estuve en Paris. De igual forma quiero agradecer la hospitalidad del profesor Jacques Bidet, además de manifestar mi deuda intelectual con su trabajo. Esta investigación no hubiera podido ser realizada con éxito sin las innumerables horas de diálogo con Gerardo Ambriz, compañero de viaje desde hace ya más de un lustro. Agradezco igualmente a Oswaldo Varillas, esa máquina de pensar que nunca cesa y a la que siempre trato de seguir...perpetuum mobile. Pero, sobre todo, agradezco a mi familia por su apoyo infinito, su amor incondicional, su eterna compañía y, sin duda, a Érika Paz, quien no sólo me ha enseñado a pensar sino que día con día me enseña a ser una mejor persona, lo cual, tratándose de mí, no debe ser nada fácil. 
“pobres laboriosos” libres, ese producto artificial de las sociedades modernas Marx, El Capital

Ainsi du beau nom de liberté elle avait fait le mot de l'ordre de l'oppression matérielle des classes inférieures

Pierre Leroux 


\section{Introducción}

En los últimos 40 años el mundo ha sido testigo de profundas transformaciones a nivel político, económico y cultural. La magnitud de semejantes modificaciones parece haber trastornado de manera decisiva el horizonte de las luchas políticas y las reivindicaciones sociales de nuestro tiempo. La fuerza con la que emergieron temas como la defensa de las minorías y el respeto a los derechos humanos iluminó un sin número de problemáticas olvidadas durante décadas por buena parte del pensamiento crítico, al tiempo que permitió sustituir un vocabulario cada vez más distante de las exigencias de nuestra época. Sin embargo, detrás de este afortunado desplazamiento conceptual comenzó a tener lugar otro reacomodo profundo, tan profundo que podría caracterizarse como un verdadero movimiento telúrico en el orden de nuestros discursos. Nos referimos, desde luego, a la paulatina desaparición del conflicto entre capital y trabajo de las coordenadas de nuestro léxico político.

$\mathrm{Al}$ menos desde los años 70’s los asuntos laborales comenzaron a ser relegados de nuestro horizonte discursivo. En el terreno de la filosofía política, la llamada centralidad del trabajo fue ocupada por los debates sobre la justicia ${ }^{1}$ o el reconocimiento, ${ }^{2}$ las discusiones sobre la compatibilidad de los derechos universales con las identidades culturales o, en otro registro teórico, las luchas para construir subjetividades alternativas. ${ }^{3}$ Ciertamente, la incorporación de derechos sociales en la mayoría de las constituciones europeas otorgaba argumentos a quienes consideraban que el conflicto entre capital y trabajo se hallaba esencialmente solucionado: era cuestión de tiempo para que, transitando a regímenes democráticos, los países más atrasados terminaran por incluir mecanismos destinados a garantizar los derechos sociales de toda la ciudadanía.

Sin embargo, lo ocurrido en las últimas cuatro décadas parece poner en duda esta certidumbre. Durante estos años una oleada de cambios a escala planetaria ha terminado por romper el frágil equilibrio entre capital y trabajo establecido en Europa a partir de la posguerra. Rememorando la célebre obra de Karl Polanyi, el sociólogo Robert Castel habla

\footnotetext{
${ }^{1}$ Cfr. Rawls, John, Theory of justice, Oxford University Press, Oxford, 1971.

${ }^{2}$ Cfr, Honneth, Axel, Lucha por el reconocimiento. Por una gramática moral de los conflictos sociales, Crítica, Barcelona, 1997.,

${ }^{3}$ Cfr, Butler, Judith, El género en disputa, Paidos, Barcelona 1999.
} 
de un nueva "gran transformación” ${ }^{4}$ a nivel global, una honda restructuración en las bases de nuestra organización social que tiene como protagonistas a los nuevos sujetos del mundo del trabajo.

Aunque semejante reconfiguración está vinculada a procesos económicos y políticos extremadamente complejos, una matriz discursiva cada vez más amplia tiende a interpretarla como el resultado inevitable de los avances científicos y tecnológicos de nuestro tiempo en el contexto de la globalización. ${ }^{5}$ Así, como ocurre en otros tantos ámbitos de la realidad, el

${ }^{4}$ Castel, Robert, El ascenso de la incertidumbre, FCE, México, 2010.

${ }^{5}$ Por ejemplo, a decir de pensadores como Peter Drucker, conocido como el padre del managment, nos encontramos en la antesala de una sociedad post-capitalista cuya tendencia es la paulatina supresión del capital como principal recurso de producción y la aparición del conocimiento como factor clave del desarrollo económico. Según Drucker, el antagonismo existente entre capital y trabajo, propio de las sociedades capitalistas, está llamado a ser superado en las sociedades emergentes ya que, desde su perspectiva, el conocimiento es un factor absolutamente intransferible. Los análisis de Drucker han tenido una repercusión fundamental en las áreas de administración y gestión de recursos humanos donde se ha echado a andar una fraseología destinada a enfatizar el valor inalienable del conocimiento y la necesidad de que los empleados asuman los costos de capacitación como inversiones en sí mismos (Cfr. Drucker, Peter, Post-Capitalist Society, Harpers Collins, 1994). Esta fraseología ha influido también en la redefinición de los discursos económicos de múltiples naciones, las cuales incluso han comenzado a hablar de una economía del conocimiento. A estas dos perspectivas deben sumarse el entramado discursivo que la Organización para la Cooperación y el Desarrollo Económico (OCDE) ha utilizad en sus recomendaciones a los países miembros destinadas a renovar el panorama laboral de su población. Aludiendo a las exigencias de un mundo globalizado se apela a la flexibilización laboral, la subcontratación, la descolectivización del trabajo y la eliminación de regulaciones “innecesarias". Estas medidas, aparecen como los pilares de una visión del empleo radicalmente distinta a la que podíamos encontrar en las instituciones internacionales apenas hace medio siglo (Novelo, Federico, De Keynes a Keynes, UAM, México,2011, p.153). En el fondo, estas recomendaciones ponen de manifiesto un recambio profundo en la organización de la fuerza laboral al interior de las empresas, así como una transformación sustantiva de las políticas gubernamentales en materia laboral. En el primer caso, las modificaciones responden al agotamiento del sistema fordista-taylorista y a los eficaces resultados del emergente sistema toyotista; en el segundo, obedecen a la necesidad de superar el modelo económico de posguerra sustentado en las ideas keynesianas mediante la implementación de un conjunto de medidas destinadas a enfrentar la crisis económica de los años 70. Esta constelación discursiva ha tenido amplias consecuencias: por un lado, ha ayudado a articular nuevas prácticas de eficiencia y productividad en el interior de los centros de trabajo, al tiempo que otorga una justificación teórica para la implementación de políticas gubernamentales difícilmente aceptables antes de los años 70. Pero también es posible identificar un efecto menos visible, aunque igualmente importante: la neutralización casi absoluta de aquellos discursos que enfatizaban las contradicciones existentes en la relación entre capital y trabajo. En efecto, postular el fin de las sociedades capitalistas supone aceptar la muerte de ese conflicto, con lo cual resulta fácil desechar uno de los frentes de crítica social más importantes durante el siglo XX: aquel que denunciaba el mecanismo de explotación laboral inherente al desarrollo capitalista y, por lo mismo, apelaba a la destrucción de ese sistema económico o a la incorporación de restricciones jurídicas para aminorar sus efectos perniciosos. Por su parte, la fusión entre el modelo toyotista y las políticas de corte neoliberal han terminado por crear un complejo discurso donde la terminología empresarial comienza a sustituir el lenguaje de los derechos, al tiempo que responsabiliza al trabajador por sus condiciones de precariedad (Senneth, Richard, La corrosión del carácter, Anagrama, Barcelona, 2010). Sin embargo, la proliferación de discursos sobre los beneficios de los nuevos mecanismos de producción, las bondades de la flexibilidad laboral, la preponderancia del capital humano y la nueva tendencia a la descolectivización, encubren un hecho fundamental: desde hace 40 años la precarización del trabajo, el debilitamiento de los sistemas de protección y la disminución de los salarios reales se han vuelto moneda corriente (Boltansky Luc, El nuevo espíritu del capitalismo, Akal, Madrid, 2010). 
trabajo habría terminado por adaptarse a las exigencias de un mundo cada vez más desarrollado. Desde esta perspectiva, el último clavo en el ataúd de los viejos discursos sobre el trabajo habría sido colocado por su incapacidad para dar cuenta de las significativas reconfiguraciones vividas en el orbe durante las últimas décadas. Aunque semejante afirmación no es del todo falsa, la situación que hemos vivido en años recientes puede interpretarse de otra manera. En realidad, los viejos discursos sobre el trabajo no se hicieron obsoletos gracias al ineluctable paso de los años: por el contrario, ocurrió que sus objetos de análisis, las preguntas que se planteaban y los problemas a los que intentaban dar respuesta, terminaron por ser desplazados del espacio discursivo actualmente dominante.

Sin duda, las causas de este desplazamiento pueden ser analizadas desde la perspectiva de las estructuras económicas y las exigencias del Sistema-mundo. ${ }^{6}$ Aunque estos análisis resultan ineludibles para comprender el papel del trabajo en nuestras sociedades, ${ }^{7}$ también es posible ensayar un acercamiento distinto. Dicho acercamiento no sería el de las necesidades de la lógica de acumulación de capital o el de los acomodos geopolíticos, sino aquél que trata de determinar cuáles son las condiciones que hacen posible la emergencia de una forma de problematización. No se trata, sin embargo, de analizar esas condiciones en el plano de la historia de las ideas o de las mentalidades, sino en el de la formación de dispositivos de saber-poder anclados tanto en prácticas discursivas como en prácticas de gobierno. $^{8}$

La investigación que aquí presentamos se enmarca en un proyecto más amplio destinado a estudiar las condiciones que han hecho posible esa particular forma de problematización del trabajo en la cual los seres humanos no sólo son instados a concebir su actividad laboral como un bien mercantil, sino su propia subjetividad como una empresa

\footnotetext{
${ }^{6}$ Retomo la distinción entre estructura y sistema propuesta por Jacques Bidet en su obra. Al respecto véase, Bidet, Jacques, Le neo-libéralisme. Un autre grand récit, Les Praires Ordinaires, Paris, 2016, p.38ss.

${ }^{7}$ Tanto en la Condición de la Posmodernidad (Harvey, David, La condición de la posmodernidad, Amorrortu, Buenos Aires, 2004) como en Breve historia del neoliberalismo (Harvey, David, Breve historia del neoliberalismo, Akal, Madrid, 2010), Harvey ha analizado esta reconfiguración como parte de las necesidades del desarrollo capitalista en el contexto de sus crisis cíclicas de sobreacumulación; por otro lado, el economista italiano Giovanni Arrighi ha estudiado la reorganización de la economía global a partir del análisis de los ciclos largos de expansión capitalista (Cfr. Arrighi, Giovanni, El largo siglo XX, Akal, Madrid, 2012.); e Immanuel Wallerstein ha hecho lo propio al evidenciar la tendencia del capitalismo a mercantilizar cada vez más aspectos de la sociedad dentro de nuestro Sistema-mundo (Wallerstein, Immanuel, El moderno sistema mundo IV. El triunfo del liberalismo centrista, SXXI, México,2010).,

${ }^{8}$ Para un análisis detallado de las apuestas metodológicas de este trabajo, remito al lector al Anexo que se localiza al final del mismo bajo el nombre: "Cuestiones de método".
} 
sujeta a las mismas exigencias que atraviesan la lógica del mercado global: deslocalización, flexibilidad, adaptabilidad, etc. A la vinculación coherente de saberes y prácticas que articulan ese horizonte de racionalidad mediante el cual se interpela a los sujetos a adoptar la forma empresa como parte constitutiva de su identidad, la llamamos dispositivo neoliberal del trabajo. Esta investigación pretende establecer los cimientos para un estudio de las condiciones de posibilidad de dicho dispositivo.

Sin embargo, la problematización del trabajo en el dispositivo neoliberal no ha sido el resultado espontáneo de una concepción del mundo enteramente novedosa. Ciertamente el agotamiento del keynesianismo, la crisis del Estado Benefactor, la revolución tecnológica producida por el desarrollo de la informática y la sustitución del modelo fordista-taylorista forman parte de una causalidad histórica sin la cual el neoliberalismo es imposible de entender; no obstante, desde la perspectiva de análisis que deseamos adoptar, las causas históricas deben ser acompañadas de un análisis de las condiciones que hicieron posible la coherencia interna de los saberes y las prácticas que conforman ese dispositivo. Para ello, resulta indispensable retroceder dos siglos en el tiempo: en realidad, sólo porque el liberalismo decimonónico abrió la posibilidad de pensar el trabajo como una mercancía, el dispositivo neoliberal pudo constituirse coherentemente en la segunda mitad del siglo XX. Así, aunque el liberalismo decimonónico no es una de sus causas directas, sí es una de las condiciones de posibilidad que permitieron la emergencia de algunos de los saberes que definen la regularidad interna del dispositivo neoliberal. Por lo que resulta indispensable dar cuenta de la lógica interna del liberalismo decimonónico para poder comprender una realidad como la nuestra donde la experiencia del trabajo vuelve a ser reincorporada a un lenguaje que la interpreta, ante todo, como una entidad ligada al mercado.

Ahora bien, en oposición a quienes distinguen entre un liberalismo político y un liberalismo económico en el seno del siglo XIX, nuestro estudio intentará mostrar que la coherencia interna del liberalismo decimonónico realmente existente sólo pudo sostenerse cuando la actividad laboral fue identificada con las exigencias del mercado. Así, en tanto acontecimiento histórico, el liberalismo fue menos una doctrina política o una teoría económica que un dispositivo, un entramado coherente de saberes y prácticas enteramente vinculadas a lo que ocurría en el mundo del trabajo. Antes de que los sujetos fueran instados a pensar su subjetividad en términos empresariales, el liberalismo problematizó la actividad 
laboral en un sistema coherente de ideas y prácticas en las cuales dicha actividad era estudiada como un factor más de las dinámicas del mercado: sin esta forma de problematización la coherencia interna del liberalismo histórico -a la vez político y económico- hubiera sido absolutamente impensable.

Esta constatación nos ha llevado a reconsiderar algunos lugares comunes sobre el liberalismo habituales en las discusiones políticas de nuestro tiempo. ${ }^{9}$ En efecto, algunos analistas tienden a retrotraerse a autores como John Locke -e incluso Thomas Hobbes- para tratar de localizar las bases teóricas de un liberalismo político que, creciendo de a poco, alcanzaría plena madurez en los siglos XVIII y XIX. ${ }^{10}$ Así, frente a los abusos de un poder estatal ilimitado, un conjunto de pensadores más o menos homogéneo habrían ido fraguando de a poco un ideario político basado en la defensa de la libertad individual, la propiedad privada y la división de poderes. Finalmente, con la implementación del sufragio universal en el siglo XIX, este ideario terminaría por establecer las bases de nuestras democracias liberales modernas.

Sin embargo, al interpretar las cosas de esta manera, tanto los defensores como los críticos del liberalismo, no han dejado de extrapolar un conjunto de problemas que sólo podían ser planteados en cierta época a autores cuyas reflexiones respondían a circunstancias enteramente singulares. ${ }^{11}$ No sólo eso, este tipo de interpretaciones favorece una concepción reduccionista de las confrontaciones políticas que han tenido lugar a partir del siglo XVIII. Aunque ataviada de algunos pincelazos históricos, la estrategia de algunos analistas consiste en mostrar cómo, en lo que corresponde a sus motivaciones ideológicas, las luchas políticas modernas fueron el resultado de la oposición entre quienes, por un lado, defendían unos “valores liberales” y aquellos que, por el otro, se oponían a ellos en favor de una serie de

\footnotetext{
${ }^{9}$ De manera que el trabajo aquí presente alberga dos objetivos concomitantes: Por un lado, representa la primera parte de un proyecto de investigación más amplio destinado a dar cuenta de las condiciones de posibilidad del dispositivo neoliberal del trabajo. El análisis del liberalismo nos colocará en condiciones de investigar la singularidad de la concepción neoliberal al permitirnos ponderar sus semejanzas, y, sobre todo, su diferencia específica. Por el otro lado, representa una crítica, a la vez epistemológica y política, a ciertas interpretaciones clásicas del liberalismo, interpretaciones habituales tanto entre sus defensores como entre sus detractores, las cuales, hasta nuestros días, han condicionado las coordenadas de los debates políticos.

${ }^{10}$ Cfr., Salazar, Luis, Para pensar la política, UAM, México, 2004; Várnagy, Tomás, "El pensamiento político de Jhon Locke y el surgimiento del liberalismo", en: Boron, Atilio, La filosofía política: De Hobbes a Marx, CLACSO, Buenos Aires, 2000.

${ }^{11}$ Aunque vinculado a los análisis de la historia conceptual, James Tully defiende una posición semejante en: Tully, James, An aprroach to political philosophy: Locke in contexts, Cambridge University Press, Great Britain, 1993, pp.96ss.
} 
"valores no-liberales". ${ }^{12}$ De esta manera, el conservadurismo, el jacobinismo, el socialismo y más tarde el estalinismo, serían la contraparte de un liberalismo democrático que, afortunadamente, habría salido victorioso de estas luchas convirtiéndose en el horizonte insuperable de nuestro tiempo. ${ }^{13}$

La tradición marxista más ortodoxa retomó las claves de esta narrativa en un sentido inverso. Mientras que en el primer caso la formación de un ideario político fundado en la libertad individual, la propiedad privada y la separación de poderes, terminaba presentándose como la expresión más acabada de la modernidad, para algunos sectores del marxismo se trataba de una ideología burguesa que encubría la dominación de una clase sobre otra. De esta forma, se argüía que a la democracia liberal moderna debía oponerse un proyecto de emancipación real en el que la libertad individual, la propiedad privada y el Estado democrático burgués fueran sustituidos. A cambio, se proponía un proyecto de transformación antropológica en el cual los impulsos comunitarios remplazarían los fines egoístas del individualismo "burgués", la colectivización de la propiedad de los medios de producción acabaría con la propiedad privada y, finalmente, la dictadura del proletariado terminaría por reemplazar a un Estado fundado en una democracia meramente formal. En esa línea argumentativa, las confrontaciones del siglo XIX serían el resultado del enfrentamiento entre una burguesía ascendente que, mediante la apelación a la libertad y la propiedad, enmascararía sus propios intereses y una clase proletaria que, poco a poco, lograría despojarse de esta ideología para consolidar unos valores propios enteramente antitéticos a los defendidos por la burguesía.

Frente a esta perspectiva, fundada en idealizaciones normativas, opondremos una lectura que llamaremos genealógica. Tomando como punto de anclaje las luchas políticas de Francia en el siglo XIX, intentaremos mostrar que las confrontaciones políticas de la época respondían menos a la oposición de dos "visiones del mundo" o a una jerarquización divergente de los "valores" políticos, que a la confrontación de estrategias de poder y resistencia. Estrategias, además, que gravitaban sobre un dispositivo de saber-poder complejo cuya coherencia interna sólo se vuelve comprensible en el marco de las problemáticas precisas de su tiempo.

${ }^{12}$ Cfr, Hayek, Friedrich, Caminos de servidumbre, Unión Editorial, Madrid, 2008. En particular el apartado titulado: "Individualismo y colectivismo".

${ }^{13}$ Cfr, Fukuyama, Francis, El fin de la historia y el último hombre, Planeta, Madrid, 1992. 
En la primera parte de esta investigación trataremos de mostrar que la estrategia discursiva de los republicanos sociales de 1848 no pretendía negar la libertad individual y la propiedad privada debido a su presunto carácter burgués, sino que buscaba vincular la consolidación de los derechos políticos a la llamada cuestión social. Sin embargo, esto ocurría en un contexto muy peculiar, un contexto en el que la competencia ilimitada se presentaba como la causa principal de las penurias de los trabajadores. En un periodo en el que, además, no se reconocían los derechos políticos de los obreros, las propuestas, más o menos articuladas, de los sectores socialistas o del republicanismo social lograron vincular las peticiones de democracia y organización colectiva del trabajo para oponerlas a la llamada libertad de industria. En ningún caso se trataba de oponer la colectividad y la asociación "en abstracto" a valores políticos "liberales” como la libertad y la propiedad. Lo que realmente estaba en juego en ese periodo no tenía que ver con una disputa entre los partidarios de la "libertad de los antiguos" y los partidarios de la "libertad de los modernos", ni con la oposición entre una libertad negativa y una positiva, sino con unos conceptos, unas categorías, unas decisiones políticas y unas estrategias vinculadas al contexto específico de esa época.

No obstante, como trataremos de mostrar en la segunda parte de esta investigación, las estrategias por las que el socialismo y el republicanismo social trataban de resistir a las prácticas de gobierno que les aquejaban, sólo tenían sentido en relación a aquello a lo que se enfrentaban. Estrictamente hablando, esas prácticas de gobierno no se asentaban en algo así como una "ideología dominante", sino en un dispositivo de saber-poder que comenzó a sedimentarse apenas en el siglo XIX. La coherencia interna de ese dispositivo permitía formular un discurso con pretensiones de cientificidad en el cual la materialización de los ideales de la modernidad se vinculaba con la defensa de la libertad de un mercado concebido en términos de leyes naturales, pero, sobre todo, con una forma de problematización donde el trabajo era entendido como una realidad de la misma índole que los otros bienes mercantiles. Así, las aspiraciones de libertad y propiedad, tal como las formuló el liberalismo decimonónico, sólo eran pensables en el marco de la aparición de esta noción particular del mercado cuya condición material era el desarrollo de un capitalismo industrial inexistente siglos atrás. 
Finalmente, en el último capítulo de nuestra investigación, tratamos de mostrar cómo fue que un nuevo discurso constituido a partir de la década de 1940 pudo reapropiarse del dispositivo liberal para hacerlo funcionar en un contexto muy diferente. Esa reapropiación, sin embargo, ocurría luego de que, en mayor o menor medida, un conjunto de tradiciones intelectuales se desplazara de las coordenadas en las cuales el dispositivo liberal había ubicado el tema del trabajo. De ahí que la nueva formulación del liberalismo pudiera presentarse, a la vez, como una ruptura con el presente y como una recuperación de lo mejor de la tradición moderna. No obstante, en lo que respecta al mundo del trabajo, el neoliberalismo no sólo implica una continuidad respecto a ese gesto abierto por el dispositivo liberal mediante el cual éste se interpreta como una simple extensión del mercado, sino también una serie de novedades y rupturas altamente significativas en nuestro mundo contemporáneo. 


\section{Capítulo 1}

\section{8: la disputa por el trabajo}

Quince años después de la Revolución de 1848 Victor Hugo recordaba las barricadas de junio como "la guerra más grande de las calles que ha visto la historia”. Esta consideración no se alejaba mucho de aquella que, en esos mismos años, escribía su antiguo adversario político, Alexis de Tocqueville. En sus Souvenirs, el autor de La Democracia en América, recordaba los acontecimientos de 1848 como el momento en que surgió “l’insurrection plus singuliére qu'ait eu lieu dans notre histoire et peut-être dans aucune autre”. ${ }^{14}$ Como lo atestiguan ambos pensadores, el desenlace de la Revolución de febrero dejó una huella profunda en la memoria de Europa. Sin embargo, la impronta de esos acontecimientos no sólo era significativa debido a las dimensiones de la revuelta popular, sino porque en ella se definían los derroteros de la llamada question social.

En efecto, además de la confrontación en las calles, el año de 1848 atestiguó otra disputa cuyas resonancias históricas son acaso más prolongadas y significativas. Las jornadas de junio vieron cómo se eclipsaba la estrategia discursiva de los republicanos democráticosociales y, con ella, la aspiración de construir una institucionalidad política capaz de revertir la dependencia servil de los trabajadores mediante los instrumentos del derecho. El reverso de este ocaso fue el ascenso de un conjunto de ideas que, no sin contratiempos, se transformaron en la referencia política de la mayoría de los gobiernos europeos durante la segunda mitad del siglo XIX. Así, la coyuntura política de 1848 permitió que posturas hasta entonces antitéticas hallaran un nuevo punto de encuentro. Frente a las propuestas de los republicanos sociales, la alianza entre ex-monárquicos y republicanos moderados terminó cristalizando alrededor de una convicción: la necesidad de distinguir las obligaciones jurídicas del Estado de las vicisitudes que tenían lugar en el mundo del trabajo.

No obstante, para comprender en qué consistía la estrategia de los republicanos sociales es necesario retrotraernos a los tiempos de la I República. Y es que, en la antesala de la Revolución de 1848, fue la unión ente el neo-jacobinismo republicano y el movimiento obrero aquella que logró nutrir una visión política congruente capaz de disputar el poder con los sectores liberales. De hecho, buena parte de los principales referentes del movimiento

\footnotetext{
14 Tocqueville, Alexis, Lettres choisies. Souvenirs, Gallimard, Paris, 2003, p.862.
} 
obrero en esos años -gente como Blanqui, Blanc o Cabet- reivindicaban abiertamente la corriente democrático-fraternal de la primera República. ${ }^{15}$ Desde luego, aquello que los ligaba a esta corriente no era una morbosa atracción por el Terror, sino la idea de que una verdadera República sólo era posible si se atendían las causas que perpetuaban la dependencia material de las grandes mayorías. Veamos.

\subsection{La herencia de la fraternidad en la I República}

Apenas seis días después de la toma de la Bastilla, Emmanuel Sieyès aseguraba ante la Asamblea Constituyente que era preciso distinguir entre dos formas de ciudadanía: la ciudadanía pasiva y la ciudadanía activa. ${ }^{16}$ Los argumentos que justificaban esta posición habían sido presentado por el abate francés un mes antes en el Comité Constitucional de la Asamblea Nacional:

Todos los habitantes de un país deberían gozar en él de los derechos de los ciudadanos pasivos, todos tienen derecho a la protección de su persona, de su propiedad, de su libertad, etc. Pero no todos tienen el derecho de desempeñar un papel activo en la formación de las autoridades públicas; no todos son ciudadanos activos. Las mujeres (al menos en el momento actual), los niños, los extranjeros y aquellos otros que no contribuyen en nada al sostén del establecimiento público $(\mathrm{s} / \mathrm{n})$ no deben estar autorizados a influir activamente sobre la vida pública. Todos tienen derecho a gozar de las ventajas de la sociedad, pero sólo aquellos que contribuyen al establecimiento público son verdaderos accionistas de la gran empresa social. Sólo ellos son ciudadanos activos, verdaderos miembros de la asociación. ${ }^{17}$

Así, “aquellos que no contribuían en el sostén del edificio público” quedaban excluidos del derecho de participación política. Esta distinción fue incorporada en la Constitución girondina del 3 de septiembre de 1791 mediante un “decreto legal que definía

\footnotetext{
${ }^{15}$ Véase, por ejemplo, el prólogo de 1847 a La organización del trabajo, donde Blanc distingue claramente la revolución burguesa de 1789 de la revolución de 1793 (Blanc, Louis, Organisation du travail, Au Bureau de la Société de l'industrie fraternelle, París, 1847, p. 13). Posteriormente la historiografía marxista complicaría las cosas al incluir al movimiento jacobino en el cajón de la revolución burguesa, algo que Blanc y los republicanos franceses de la primera mitad del siglo XIX se habían negado a hacer con toda razón. Otro ejemplo de la influencia jacobina en los republicanos de 1848 es Cabet, quien, antes de publicar su famoso Viaje a Icaria, escribió una extensa historia de la revolución en la que mostraba a Robespierre como un héroe político (Harvey, David, París, capital de la modernidad, Akal, Madrid, 2008, p. 94).

${ }^{16}$ Cfr, Wallerstein, Immanuel, El moderno sistema... op.cit. p. 209. De hecho, hasta 1848 ninguna corriente política -a excepción, por supuesto, del partido de la Montaña- se atrevió a cuestionarla, a lo mucho habían ensanchado o limitado el umbral de la ciudadanía activa, pero jamás se promovió la desaparición de las fronteras entre ambas denominaciones.

17 Sieyès, Emmanuel, Escritos y discursos de la Revolución, Centro de Estudios Políticos y Constitucionales, Madrid, 2007, p. 259.
} 
a los ciudadanos activos como aquellos que pagaban un mínimo de tres días de salario como impuesto directo”. ${ }^{18}$ Ahora bien, la justificación de esta medida se sostenía en un razonamiento peculiar, a saber: si los no-propietarios dependían de terceros para subsistir su voluntad no podía considerarse libre ya que se encontraba empeñada de origen. De esta manera, los desposeídos eran considerados como individuos sin independencia para decidir sobre el ámbito público. ${ }^{19}$

De hecho, la artificiosa distinción entre la libertad de los antiguos y la libertad de los modernos elaborada por Benjamin Constant, ${ }^{20}$ estaba montada sobre los mismos principios que legitimaban el sufragio censitario. En efecto, dado que en las sociedades modernas los derechos de participación política convivían con las aspiraciones de individuos deseosos de

${ }^{18}$ Wallerstein,...op. cit. 210. El objetivo era claro: restringir la ciudadanía activa y los derechos políticos a los propietarios. Michael Sewell intenta matizar esta afirmación señalando que "las exigencias para la ciudadanía activa no eran exactamente requisitos de propiedad”, (Sewell, William, Trabajo y revolución en Francia. El lenguaje del movimiento obrero en Francia desde el Antiguo Régimen hasta 1848, Taurus, Madrid, 1992.p.194). Su argumento es que, en los hechos, incluso los trabajadores asalariados podían votar pues difícilmente se les pagaba menos de la cantidad de impuestos necesaria valuada en tres días de salario mínimo. Con lo cual, según sus datos, dos tercios de la población de varones en edad de votar tenían la ciudadanía activa. Sin embargo, inmediatamente después señala que, si bien los requisitos para votar eran relativamente suaves, los que se pedían para ser votados eran extremadamente restrictivos, pues: "no servía nadie que no fuera propietario, rentista o usufructuario de una propiedad muy grande” (Ibid. p. 194). Así que, aún si nos atenemos a la consideración de Sewell, acceder a los espacios de decisión pública era un privilegio exclusivo para los grandes propietarios. En todo caso, los ciudadanos no- propietarios sólo tenían derecho a votar por los grandes propietarios. Ahora bien, la medida más o menos "laxa” que estableció un impuesto de tres días de salario para votar, únicamente duró un par de años, con el ascenso de los jacobinos al poder se eliminó temporalmente la distinción entre ciudadanía activa y ciudadanía pasiva. Sin embargo, después del golpe a Robespierre, la Comisión termidoriana decidió aumentar el aporte fiscal de tres jornadas de trabajo a ¡200! (Domènech, Antoni, El eclipse de la fraternidad, Crítica, Barcelona, 2004p. 2003:93). Hacia 1848, siete de cada diez varones estaban excluidos de la ciudadanía activa.

${ }^{19}$ En la Metafísica de las Costumbres el propio Kant había afirmado que la "independencia civil” -esto es: el "no agradecer la existencia y la conservación al arbitrio de otro" (Alegre, Luis; Fernández, Carlos, El orden de El Capital, Akal, Madrid, 2010, p. 598)- era condición necesaria para la ciudadanía activa. De donde se deducía que quienes dependían de otro para vivir no podían ser partícipes de la vida política, como los niños, las mujeres, los siervos y los asalariados. En "Sobre el tópico: Esto puede ser correcto en teoría, pero no vale para la práctica”, el alemán defendía esta posición sin dejar lugar a ninguna ambigüedad: "La única cualidad exigida para ello [ser ciudadano], aparte de la natural (no ser niño, ni mujer) es la de que uno sea su propio señor (sui iuris) y, por tanto, tenga alguna propiedad" (Kant, Immanuel, En defensa de la Ilustración, Alba Editores, Barcelona, 1999, p. 266). El mismo argumento era sostenido por John Adams en América: "Los hombres en general, de cualquier sociedad, que están totalmente desposeídos de tierra conocen tan poco los asuntos públicos que no pueden opinar rectamente, y dependen tanto de otros hombres que carecen de una voluntad propia. Hablan y votan tal y como les recomienda algún hombre rico que ha moldeado sus mentes para que defiendan sus intereses de propietario" (citado en: Ovejero, Félix, Incluso un pueblo de demonios: democracia, liberalismo, republicanismo, Ed. Katz, Madrid, 2008, p.125).

${ }^{20}$ Quien, precisamente, fue partidario de los termidorianos que dieron el golpe frente al gobierno jacobino de Robespierre. 
realizar sus intereses particulares, la dirección política de la comunidad debía ser encomendada a un conjunto de representantes:

[...] dans l'espèce de liberté dont nous sommes susceptibles, plus l'exercice de nos droits politiques nous laissera de temps pour nos intérêts privés, plus la liberté nous será précieuse [...]. Le système représentatif n' est autre chose qu'une organisation à l'aide de laquelle une nation se décharge sur quelques individus de ce qu'elle ne peut on ne veut pas faire ellemême. $^{21}$

No obstante, la verdadera cuestión consistía en saber quiénes eran esos individuos que no querían y, sobre todo, quiénes eran los que no podían hacer uso de sus derechos políticos. Esta distinción no era intrascendente, en sus Principes de politique el autor había resuelto la cuestión con absoluta claridad:

Il faut donc une condition de plus que la naissance sur le territoire et l 'âge prescrit par la loi. Cette condition, c'est le loisir indispensable à l'acquisition des lumières, à la rectitude du jugement. La propriété seule assure ce loisir. La propriété seule rend les hommes capables de l'exercice des droits politiques. Les propriétéres seuls peuvent être citoyens. ${ }^{22}$

En efecto, dado que los asalariados carecían “de las rentas necesarias para vivir independientemente de toda voluntad ajena”, "los propietarios [eran] dueños de su existencia ya que [podían] negarles el trabajo”. ${ }^{23}$ Sin embargo, aunque la condición de dependencia de los trabajadores les impedía acceder a la esfera política, no por ello debía deducirse que se atentaba contra su libertad (moderna). Esta última tenía poco o nada que ver con los derechos de participación. La argumentación de Constant justificaba que personas materialmente dependientes sin derechos políticos fueran concebidas como individuos libres dentro del mundo moderno. Una pretensión que recorrió toda la primera mitad del siglo XIX.

Sin embargo, los trabajadores pobres no sólo sufrían de la exclusión política. Tanto en el ámbito rural como en el urbano, la dependencia de los sectores más desfavorecidos respecto a los grandes propietarios ponía en juego la vida misma de los primeros. En Pobreza

${ }^{21}$ Constant, Benjamin, Écrits politiques, Gallimard, Paris, 1997, p. 616ss.

${ }^{22}$ Constant, Benjamin, Principes de politique, Chez Alexis Eymeri, Paris, 1815.Chapitre 6.

${ }^{23}$ Citado en: Losurdo, Doménico, Contrahistoria de liberalismo, El Viejo Topo, s/l, 2005, p. 189. De hecho, siguiendo el argumento de Constant, se presentó una propuesta para el proyecto de la Constitución de Apatzingan, en México, donde se perfilaba la posibilidad de prohibir los derechos democráticos a los no propietarios. Cfr. Reyes Heroles, Jesús, El liberalismo mexicano I. FCE, México, 2007, p. 326. 
y capitalismo en la Europa preindustrial Catharina Lis y Hugo Soly ofrecen un panorama esclarecedor de esas circunstancias:

[los trabajadores rurales] no poseían tierras o tenían demasiado poca para mantener una familia, y sus insignificantes ingresos dependían de numerosas incertidumbres. Una mala cosecha ponía los precios de los alimentos en las nubes y disminuía la demanda de mano de obra agrícola, de modo que el presupuesto quedaba doblemente afectado. En la mayoría de los casos, una seria carestía ocasionaba el colapso de la manufactura textil, con el resultado de que todos aquellos que vivían de la industria doméstica se enfrentaban al subempleo o al desempleo total. ${ }^{24}$

Las cosas no eran muy diferentes para el incipiente conjunto de asalariados que trabajaban en las urbes:

El asalariado urbano se extendía de igual modo \{...]En vísperas de la Revolución Francesa, los asalariados representaban un 48 por 100 de los habitantes de Troyes, un 50 por 100 en Nantes y un 60 por 100 en Elbeuf. La pobreza de esta categoría es difícilmente discutible. En Elbeuf, hacia 1790, los asalariados representaban únicamente el 8 por ciento de los propietarios y controlaban juntos apenas el 4 por 100 de la riqueza total. Por la misma época, cerca de la mitad de la población de Toulouse no poseía nada al casarse, excepto muebles y otros bienes hogareños de poco valor. Sus herencias indican que la vida matrimonial de las clases bajas, rara vez o nunca, les permitía mejorar su situación material. Por el contrario, la mayoría de los asalariados sólo dejaban deudas, y aquellos que sorprendían a sus herederos con un excedente, disponían en conjunto menos del 1 por 100 de la riqueza. ${ }^{25}$

Sin embargo, el asalariado urbano no poseía la capacidad organizativa que adquiriría medio siglo después. En su gran mayoría, la población francesa estaba compuesta por hombres y mujeres ligados al mundo rural carentes de toda propiedad significativa, un sector que, además de ver su existencia constantemente amenazada por las turbulencias económicas, se encontraba excluido de la esfera política. No resulta difícil comprender que, al detonar la Revolución de 1789, sus reivindicaciones libertarias se centraran en la regulación de las ingentes e ilegitimas diferencias de propiedad existentes en la época, pero también que concibieran el reconocimiento de sus derechos políticos como una herramienta indispensable para ese objetivo.

\footnotetext{
${ }^{24}$ Lis, Catherine, Soly, Hugo, Pobreza y capitalismo en la Europa preindustrial (1350-1850), Akal. Madrid, 1982, p. 191.

${ }^{25}$ Ibid.
} 
Ahora bien, el único discurso que recuperaba ambas demandas en una estrategia más o menos coherente era el que había habilitado el jacobinismo radical. ${ }^{26}$ En efecto, antes de que la Asamblea Constituyente instaurara el sufragio censitario, el diputado Maximilien Robespierre se opuso frontalmente a la división entre ciudadanos activos y pasivos con el siguiente argumento:

Todos los ciudadanos, sean quienes sean, tienen derecho a aspirar a todos los grados de representación. No hay nada más conforme a vuestra Declaración de derechos, ante la cual todo privilegio, toda distinción, toda excepción deben desaparecer. La Constitución establece que la soberanía reside en el pueblo, en todos los individuos del pueblo. Cada individuo tiene, pues, el derecho de contribuir a la ley por la cual él está obligado, y a la administración de la cosa pública, que es suya ${ }^{27}$. Si no, no es verdad que los hombres son iguales en derechos, que todo hombre es ciudadano(c/n) [...] cada ciudadano tiene el derecho de contribuir a la ley, $\mathrm{y}$ a partir de ahí, el de ser elector o elegible, sin distinción de fortuna. ${ }^{28}$

Según Robespierre, lejos de acabar con el despotismo, la división entre ciudadanos activos y pasivos promovía una forma de gobierno que perpetuaba una de los peores tipos de servidumbre, a saber: la aristocracia de los ricos. Refiriéndose a la incorporación del sistema censitario en la primera Declaración de los derechos del Hombre y del Ciudadano el francés afirmaba:

Que serait votre déclaration des droits si ces décrets pouvaient subsister ? Une vaine formule. Que serait la nation ? Esclave ; car la liberté consiste à obéir aux lois qu'on s'est données, et la servitude à être contraint de se soumettre à une volonté étrangère. Que serait votre constitution ? Une véritable aristocratie. Car, l'aristocratie est l'état où une portion des citoyens est souveraine et le reste sujet. Et quelle aristocratie ! La plus insupportable de toutes ; celle de riches. ${ }^{29}$

\footnotetext{
${ }^{26}$ Conviene recordar que, por cuestiones metodológicas, aquí nos limitamos a mostrar cómo funcionaba la estrategia discursiva del jacobinismo radical en lo relativo a la conformación de la idea de fraternidad y no la psicología de sus personajes o las consecuencias de su gestión. No sólo evitamos analizar la “personalidad” de las figuras jacobinas porque no la creemos fértil para un análisis como el que intentamos llevara a cabo, sino porque sólo recientemente la historiografía francesa ha empezado a analizar el periodo jacobino más allá de adscripciones ideológicas que enturbiaron el debate durante años.

${ }^{27}$ Compárense los usos retóricos del discurso de Sieyés con el discurso de Robespierre, mientras aquél compara el orden público con una gran empresa en la que solo los accionistas pueden participar de las decisiones, éste habla de la República como una institución jurídica en la que la ley sirve como instrumento de igualación social. ${ }^{28}$ Robespierre, Maximilien, Por la felicidad y por la libertad. Discursos, El Viejo Topo, s/a, p.25.

${ }^{29}$ Robespierre, Maximilien, Euvres complètes, Paris, PUF/ Société des études robespierristes, 1950, vol VI, p.162.
} 
De esta forma, como afirmaba Marat, fundador del influyente periódico L'amie de peuple, las promesas de libertad e igualdad defendidas por el ala girondina se sostenían en la exclusión política de los sectores más desfavorecidos:

Ya vemos perfectamente, a través de vuestras falsas máximas de libertad y de vuestras grandes palabras de igualdad, que, a vuestros ojos, no somos sino la canalla. ${ }^{30}$

Sin embargo, el jacobinismo radical no se limitaba a defender la extensión total de los derechos políticos, sino que vinculaba esta exigencia con otro objetivo de primer orden: el de acabar con las formas de dependencia material generadas por las diferencias en el acceso a la propiedad. ${ }^{31}$ No obstante, esto no hacía que el jacobinismo buscara la abolición del derecho a la propiedad, ${ }^{32}$ su intención era modificar la redacción de la Declaración de los Derechos del Hombre y del Ciudadano de 1791 que terminaba beneficiando a los más ricos para garantizar, por el contrario, condiciones de acceso a la propiedad por parte de todos los ciudadanos:

En définissant la liberté, le premier de biens de l'homme(c/n), le plus sacré des droits qưil tient de la nature, vous avez dit avec raison qu'elle avait pour bornes le droits d'autrui: pourqui n’́avez-vous pas appliqué ce principe à la propriété, qui est une institution sociale?[...] Vous avez multiplié les articles pour assurer la plus grande liberté à l'excercice de la propieté, et vous n'avez pas dit un seul mot pour en déterminer le caractère légitime; de manière que votre déclaration paraît faite, non pour les hommes, mais pour les riches, les accapareurs, pour les agioteurs et pour les tyrans). ${ }^{33}$

\footnotetext{
${ }^{30}$ Citado en: Domenéch, ...op.cit...p. 12. Aunque en circunstancias distintas, algo semejante ocurría con el incipiente movimiento obrero inglés, el cual exigía la instauración del sufragio universal como una de las vías para enfrentar la falsa libertad de la que el régimen inglés se vanagloriaba, mientras los trabajadores debían soportar una vida de penurias (Thompson, E.P. La formación de la clase obrera. Tomo I. Crítica, Barcelona, 1989, p.71ss.).

${ }^{31}$ Esto, sin embargo, no se debía a que los jacobinos valoraran la igualdad material por encima de la libertad individual, como parece sugerir Hannah Arendt en su famosa comparación entre la Revolución francesa y la Revolución norteamericana (Arendt, Hannah, Sobre la Revolución, Alianza, Madrid, 2006), sino a las circunstancias históricas del momento y al particular ordenamiento que el espacio discursivo tenía entonces. En efecto, dado que la justificación del exilio de la esfera política sufrido por las clases desposeídas se fundaba en su dependencia material, se volvía necesario combatir los resortes de esa dependencia para ampliar los derechos políticos a todos los hombres.

${ }^{32}$ Robespierre lo afirmaba de manera nítida: "Tenemos propiedades para poder vivir. No es cierto que la propiedad se oponga a la subsistencia del hombre” (Citado en: Bouloiseau, Marc, La República jacobina. 10 de agosto 1792-9 de termidor año II, Ariel, Barcelona, 1980, p. 51.

${ }^{33}$ Robespierre, Maximilien, Discours sur la religión, la République, l'esclavage, Éditions de l'aube, s/l, 2013.p.69
} 
Así, en su famosa alocución del 24 de abril de 1793 el francés presentaba una nueva redacción de la Declaración que incluía importantes modificaciones en los artículso referentes a la propiedad:

II. Le droit de propriété est borné, comme tous les autres, par l'obligation de respecter les droits d'autrui.

III. Il ne peut préjudicier ni à la sûrete, ni à la liberté, ni à l'existence, ni à la propiété de nos semblables. ${ }^{34}$

Con ello, como aseguraba el propio Robespierre, no se trataba de "nivelar" las condiciones materiales de toda la ciudadanía, ${ }^{35}$ ni de oponer la igualdad radical a la libertad, ${ }^{36}$ sino de establecer mecanismos que permitieran combatir las formas de dependencia material que habían caracterizado al Antiguo Régimen:

Il ne fallait pas une révolution, sans doute, pour apprendre à l'universe que l'extrême disproportion des fortunes est la source de bien des maux et de bien de crimes ; mais nous n'en sommes pas moins convaincus que l'égalité de biens est une chimère [...] ils s'agit bien plus de rendre la pauvreté honorable. ${ }^{37}$

"Volver honorable la pobreza”. Así podría resumirse el objetivo del jacobinismo radical. ${ }^{38}$ Y es que, a pesar de que el Antiguo Régimen había sido abolido formalmente, a finales del siglo XVIII las clases subalternas seguían acorraladas en un infinito círculo vicioso: como no eran propietarias debían someter su voluntad a un tercero para subsistir, con lo cual veían cancelado su acceso a la vida política; sin embargo, como tampoco eran activas políticamente estaban imposibilitadas para influir en las decisiones del poder. Así, por dondequiera que se mirara, su búsqueda para revertir las circunstancias que los mantenían en la miseria se encontraba neutralizada dentro del marco jurídico posrevolucionario. Para

34 Ibid.

35 Esta idea se encuentra literalmente el informe Courtois donde se afirma que Robespierre "buscaba la nivelación de la sociedad mediante la extinción de la riqueza y la ruina del comercio”. Sin duda, se comprende bien que tanto la aristocracia de la época, como los grandes propietarios, acostumbrados a la tolerancia del Antiguo Régimen ante el acaparamiento de la propiedad, interpretaran las modestas propuestas de Robespierre como un atentado a sus privilegios.

${ }^{36}$ Un argumento del que Tocqueville se hará eco en El Antiguo Régimen y la Revolución, véase: Capítulo 3.

${ }^{37}$ Ibid, p.67.

${ }^{38}$ Como Kant, Robespierre comprendía que los ideales de la ilustración eran impracticables si antes no eran abolidas las formas de dependencia que impedían hacer uso de la propia voluntad. No obstante, a diferencia del alemán, el jacobinismo radical asumía que no había mayoría de edad posible sin combatir las formas de dependencia material. 
acabar con este círculo vicioso, el jacobinismo radical defendía la implementación de disposiciones económicas ${ }^{39}$ destinadas a garantizar la existencia material de los desposeídos. $^{40}$ Estas disposiciones iban desde la implementación de un impuesto progresivo $^{41}$ hasta el respaldó de las demandas del movimiento campesino que luchaba por anular los excesivos cobros de los grandes propietarios rentistas a quienes se les pagaba por trabajar tierras consideradas como propiedad comunal tan sólo unas décadas atrás.

Sin embargo, la posición que mejor expresa el objetivo político del jacobinismo radical es la defendida por Robespierre ante la legislación comercial vigente en 1792. Durante el periodo girondino, la Asamblea Constituyente aprobó una ley que permitía la libertad ilimitada en el comercio de granos, ${ }^{42}$ sin embargo, los efectos de estas medidas fueron tan nocivos que en el otoño de 1792 tuvieron lugar varios motines contra los acaparadores de trigo. ${ }^{43} \mathrm{El} 2$ de diciembre de ese mismo año, Robespierre criticaba los planteamientos económicos adoptados por el ala girondina con el siguiente argumento:

Les auteurs de la théorie -se refiere a la libertad indenida de comercio- n'ont considéré les denrées les plus nécessaires à la vie que comme une marchandise ordinaire, et n'ont mis aucune différence entre le commerce du bled, par exemple, et celui de l’indigo ; ils ont plus disserté sur le commerce des grains, que sur la subsistance du peuple ; et faute d'avoir fait entrer cette donnée dans leurs calculs, ils sont fait une fausse application de principes évidens en général ; c'est ce mélange de vrai et de faux qui a donné quelque chose de spécieux à son système erroné. ${ }^{44}$

\footnotetext{
${ }^{39}$ La propuesta de Declaración de los Derechos del Hombre y del Ciudadano escrita por Robespierre en 1783 establece en su artículo X que: "La sociedad está obligada a proporcionar medios de subsistencia a todos sus miembros, sea procurándoles trabajo, sea asegurándoselos directamente a los que no están en condiciones de trabajar”. Robespierre, Maximilien, Por la felicidad...op.cit, pp.14ss.

${ }^{40}$ En esta materia, el proyecto de Robespierre se encontraba totalmente alejado de la acusación de protoestalinismo que se le haría siglo y medio después. La lectura revisionista de la Revolución Francesa homologó la figura de Robespierre con la de Stalin en el siglo XX, sin embargo, los trabajos de historiadores como Aa. Mathiez, David. P. Jordan y, más recientemente, Florence Gauthier, han desacreditado por completo esta versión, incluso un estudio nada benévolo con el jacobinismo como el de Marc Bouloiseau da cuenta de las circunstancias específicas a las que tuvo que enfrentarse la República jacobina en un contexto de asedio permanente.

${ }^{41}$ Robespierre defendía la instauración de un impuesto progresivo para financiar las despensas públicas, incluso propuso un artículo donde se exoneraba de este impuesto a los ciudadanos cuyas rentas no excedieran sus necesidades, mientras que "les autres doivent les supporter progressivement selon l'entendue de leur fortune". Robespierre, Maximilien, Discours..., p. 70).

42 Esta ley se encontraba inspirada en los análisis de Turgot y buscaba que todos los bienes, incluidos los de primera necesidad, estuvieran regulado spor el mercado sin la intervención de ningún control social.

${ }^{43}$ Ante estos disturbios, la respuesta del gobierno consistió en implementar una ley marcial para sofocarlos. Robespierre se refirió a estas medidas de la siguiente manera: "Libertad indefinida de comercio y bayonetas para calmar la alarma o para oprimir el hambre. Tal fue la política alabada por nuestros primeros legisladores” (Robesierre, Maximilien, Por la felicidad...op.cit.p.156).

${ }^{44}$ Robespierre, Maximilien, Euvres. Tome IX, Phénix Éditions, Paris, 2000, pp. 111-112.
} 
Más adelante afirmaba:

Le bon sens, par exemple, indique cette vérité, que les denrées qui ne tiennent point aux besoins de la vie, peuvent être abandonnées aux spéculations les plus illimitées du commerçant [...] Il n’est pas nécessaire que je puisse acheter de brillantes étoffes ; mais il faut que je sois assez riche pour acheter du pain, pour moi et pour mes enfants. Le négociant peut bien garder, dans ses magasins, les marchandises que le luxe et la vanité convoitent jusqu'a ce qu'il trouve le moment de les vendre au plus haut prix possible ; mais nul homme n'a le droit d'entasser des monceaux de bled, à côte de son semblable qui meurt de faim. ${ }^{45}$

Ahora bien, la defensa de las restricciones a las grandes propiedades y al comercio de los bienes de subsistencia no respondía a una supuesta prioridad de lo colectivo sobre lo individual, sino a las circunstancias particulares de un mundo en el que la implementación de cierta visión de la libertad de comercio terminaban perpetuando la dependencia material de buena parte de la población. ${ }^{46}$ Como Emmanuel Sieyès o Benjamin Constant, Robespierre defendía la libertad de los individuos y la igualdad de derechos sobre los privilegios minoritarios, pero, a diferencia de ellos, consideraba que la realización de estos ideales dependía de la capacidad de la sociedad para impedir que la subsistencia de los hombres estuviera supeditada a las necesidades de los grandes propietarios.

Esto último implicaba asumir que, como la propiedad, la libertad o la seguridad, la existencia misma era un derecho imprescriptible, un derecho sin el cual todos los demás carecían de razón de ser:

¿Cuál es el primer objetivo de la sociedad? Es mantener los derechos imprescriptibles del hombre (c/n). ¿Cuál es el primero de estos derechos? El derecho a la existencia.

La primera ley social es pues la que garantiza a todos los miembros de la sociedad los medios de existir. Todos los demás están supeditados a éste. ${ }^{47} \mathrm{La}$ propiedad no ha sido garantizada para otra cosa que para cimentarlo. Se tienen propiedades, en primer lugar, para vivir. No es cierto que la propiedad pueda oponerse jamás a la subsistencia de los hombres. ${ }^{48}$

\footnotetext{
${ }^{45}$ Ibid.112.

46 Tampoco es verdad que esas medidas valoraran la felicidad del pueblo como algo superior a la libertad individual, ni una etérea voluntad popular por encima del derecho como afirma Hannah Arendt (Arendt, Hannah, Sobre... op.cit. p.152ss).

${ }^{47}$ Aquí, el intento conceptual de distinguir entre una libertad negativa y una libertad positiva sólo sirve para encubrir las evidencias históricas. En el fondo, de lo que se trataba era de una concepción de los derechos de propiedad privada carente de toda limitación. incluso cuando se pusiera en riesgo la existencia de los nopropietarios, frente a quienes defendían, no la eliminación del derecho de propiedad privada, sino su limitación en casos concretos.

${ }^{48}$ Robespierre, Maximilien, Por la felicidad...p.157-158. Cuando en 1793 el derecho a la existencia fue incorporado a la Declaración de los Derechos del Hombre y del Ciudadano, no sustituyó la garantía de
} 
Ahora bien, al sortear los obstáculos económicos que perpetuaban la dependencia material de los desposeídos, el derecho a la existencia también garantizaba su acceso a la esfera política. Así, el núcleo del proyecto jacobino-fraternal yacía en la correlación de ambos elementos: no se podía ser ciudadano libre con derechos políticos sin enfrentar las causas de la dependencia material, pero tampoco se podían enfrentar esas causas sin extender los derechos políticos a las clases desposeídas.

En ese contexto, la incorporación de la palabra fraternidad a los principios de libertad e igualdad, intentaba evidenciar la distancia existente entre el proyecto popular republicano y la supuesta libertad (moderna) instaurada desde 1789. Una libertad que, como ya hemos dicho, les había sido otorgada a todos los ciudadanos por igual a pesar de clausurar el acceso a la vida política de un importante sector de los mismos. Para evidenciar esta circunstancia, Robespierre echó mano de una metáfora anclada en el mundo familiar: ${ }^{49}$ la relación de los pobres respecto a los propietarios podía compararse con la situación de heteronomía que vivían los hijos respecto a sus padres. Un verdadera Revolución popular, por el contrario, debía procurar relaciones de isonomía parecidas a las existentes entre hermanos (en latín frater).

De este modo, cuando a finales del siglo XVIII el jacobinismo radical hablaba sobre una República fraternal no hacía alusión a una utopía romántica, sino a una comunidad política capaz de incluir a las clases subalternas en el ámbito público cortando los lazos de

propiedad, ni la libertad de prensa y de asociación, mucho menos el derecho a resistencia ante la opresión. De hecho, como el propio Locke había defendido un siglo atrás, el carácter fundamental del derecho a la propiedad descansaba en su capacidad para asegurar la subsistencia y la libertad de los hombres en tanto no dependientes a ningún tercero. Otra cosa muy distinta es que la aristocracia rentista de la época y la naciente burguesía quisieran defender ese derecho restringiendo su significado al de derecho a la propiedad patrimonial específica de los actuales propietarios. Sólo desde esa perspectiva podía defenderse que la redistribución de la tierra iniciada por el ala jacobina con el fin de universalizar los derechos de propiedad era un atentado contra estos últimos.

${ }^{49}$ De hecho, la remisión al ámbito familiar ni siquiera era una metáfora propiamente dicha. En los hechos, hasta antes de la Revolución, las clases subalternas únicamente estaban sujetas al derecho de familia pues no eran susceptibles de derechos civiles y mucho menos de derechos políticos. Incluso, si se leen con atención, las primeras páginas del Segundo ensayo sobre el gobierno civil establecen una distinción radical entre la ley política y la ley de familia, lo cual muestra hasta qué punto la crítica a los gobiernos absolutistas se fundaba en la ilegítima extensión que los monarcas hacían del poder autoritario familiar al mundo político. A pesar de que Locke distingue entre estos dos ámbitos señala que hay quienes legítimamente son sujetos de derecho familiar, a saber: las mujeres, los niños y los siervos. Es decir, aquellos que dependen de un tercero ya sea por su minoría de edad, por la naturaleza o por la falta de propiedad (Cfr. Locke, John, Segundo Tratado sobre el Gobierno Civil, Alianza, Madrid, 2004, p.76). 
su dependencia patriarcal. ${ }^{50}$ Ahora bien, la inclusión igualitaria de todos los ciudadanos en la esfera política -y con ella, la abolición de la división artificial entre una libertad de los antiguos y una libertad de los modernos- era la única vía por la cual la soberanía podía dejar de pertenecer a una minoría favorecida por su acceso a la propiedad para residir efectivamente en el pueblo en su conjunto. No era ninguna casualidad que en pleno periodo revolucionario la única corriente identificada con la democracia fuera el jacobinismo radical, ${ }^{51}$ pero tampoco que los participantes del movimiento democrático en la Inglaterra monárquica de principios del siglo XIX fueran considerados como una versión inglesa del jacobinismo. ${ }^{52}$

En ese sentido, el proyecto fraternal del jacobinismo radical era inseparable del principio democrático ${ }^{53}$ que hacía descansar la autoridad del gobierno en el pueblo. ${ }^{54}$ Sin embargo, este vínculo no se fundaba en una especie de prioridad de la voluntad popular sobre el orden institucional ${ }^{55}$-como ha interpretado buena parte de la tradición liberal- ${ }^{56}$ sino en

50 En palabras de Antoni Domenèch: “fraternidad implica potencialmente la entrada en la ley civil, es decir, la libertad/igualdad de todos los domésticamente subalternos: esclavos, criados, clientes, oficiales, aprendices, obreros sometidos a patrón [...]” (Domenèch,... op. cit.. p. 87).

51 Además, desde luego, de los sans-culottes. Sin embargo, con todos sus conflictos internos, el movimiento sans-colottes encontró en los jacobinos un aliado en el proyecto de implementar una República democrática.

52 Thompson...,op.cit. p.160ss.

${ }^{53}$ Sin duda, a buena parte de los actuales estudiosos de la democracia le parecerá chocante ver involucrado al tan desprestigiado Robespierre en un concepto que hoy está rodeado del más absoluto prestigio. En efecto, los modernos análisis sobre la democracia no acostumbran incluir al Incorruptible entre las páginas de sus textos. $\mathrm{Al}$ parecer, esto se debe a que, al hablar de democracia, el francés se refería a algo esencialmente distinto a lo que actualmente entendemos por ella. Desde esta perspectiva, nuestra democracia no debería mucho a la tradición jacobina, aunque sí a la tradición liberal. Al respecto véase el caso paradigmático de Edoardo Greblo en su historia conceptual sobre la democracia (Greblo, Edoardo, Democracia, Nueva Visión, Buenos Aires 2002). Antes de despachar en media página la democracia republicana robiespierrista por considerarla incompatible con la democracia formal hace esta asombrosa afirmación: “A pesar de que el liberalismo de los modernos y la democracia de los antiguos a menudo han sido considerados alternativos, el camino a la democracia moderna, no está en absoluto en contraste con el liberalismo. Por el contrario, este puede considerarse la prosecución natural de aquella (c/n)” (Ibid. p. 11). A Greblo parece importarle poco que, por lo menos hasta mediados del siglo XIX, la casi absoluta mayoría de quienes se autoproclamaban liberales eran expresamente contrarios a la democracia. Con notables excepciones, la situación cambió muy poco hasta finales del siglo XIX. Si se observa con atención, la coherencia misma de los planteamientos liberales en la primera mitad del siglo XIX sólo podía sostenerse en la medida en la cual se desmarcaban conscientemente de cualquier aspiración democrática.

${ }^{54}$ Es decir, en la capacidad de insertar a todos en el ámbito de la ciudadanía activa.

${ }^{55}$ En un periodo tan turbulento como el de 1794, Robespierre definía la democracia de la siguiente manera: "La democracia es el Estado en el que el pueblo soberano, guiado por las leyes, que son su obra (c/n), hace por sí mismo todo lo que es capaz de hacer, y mediante delegados todo lo que no puede hacer por sí mismo”, (citado en: Castells Olivan, Irene, La Revolución Francesa (1789-1799), Editorial Síntesis, Madrid 1997, p.183).

${ }^{56}$ Según una idea que se ha vuelto dominante, nuestra democracia actual, formal y representativa, provendría de la tradición liberal. De esta tradición habría tomado sus principios básicos: la división de poderes, el respeto a los derechos civiles y el imperio de la legalidad. En oposición a ella, habría una democracia directa que en la 
la inclusión, en condiciones de igualdad política e independencia civil, de quienes hasta entonces habían sido excluidos de la esfera política. Así, fraternidad y democracia eran principios inseparables entre sí y opuestos a la interpretación restrictiva de la modernidad encumbrada por los autores del incipiente liberalismo. ${ }^{57}$

Cuando en la década de 1840 la noción de fraternidad vuelva a aparecer en la estrategia de los republicanos sociales lo hará manteniendo los ecos de esta época. Más que una especie de ideal utópico, la fraternidad constituirá una verdadera metáfora política. Hermanarse en tanto ciudadanos servía como una afortunada figura retórica que enmarcaba todo un programa político, a saber: el de hacer de las instituciones republicanas instrumentos para luchar contra la reproducción de las relaciones de dependencia en la esfera política y en el ámbito civil. ${ }^{58}$ Sin embargo, en la antesala de la Revolución de febrero el contexto político y económico era distinto, más importante aún: lo sujetos que, recuperando el lenguaje republicano, resistían frente a las formas de dependencia propagadas por un régimen monárquico como el de Luis Felipe, no eran ya las clases campesinas sino los trabajadores vinculados al taller y a la fábrica. Veamos.

aclamación popular, la defensa de los derechos colectivos y la superioridad de la voluntad del pueblo respecto a la ley, tendría sus principales características. Semejante división, ha sido perpetuada por buena parte del pensamiento marxista. Ahora bien, esta visión de las cosas, más o menos generalizada, dista mucho de atenerse a la realidad. Los girondinos de finales del siglo XVIII no eran una especie de proto-demócratas, eran expresamente antidemócratas; de igual forma, los autodenominados demócratas jacobinos tampoco eran una especie de proto-totalitarios. Lo que oponía a unos y otros, no era la defensa de las instituciones de democracia formal en una época donde la democracia formal no había sido conceptualizada, sino el proyecto económico que defendían y la posición que mantenían respecto al sufragio universal y sus posibles consecuencias, unas consecuencias sobrevaloradas entonces por ambos sectores.

${ }^{57}$ En palabras de Domenèch: "Democracia [...] llegó a significar a partir de 1792 la pretensión de universalizar la libertad republicana, de lograr una sociedad civil, no sólo que incorporara a todos, sino en la que todos fueran plena y recíprocamente libres, es decir iguales en el viejo sentido republicano de la palabra. Una sociedad civil en la que todos fueran sui iuris en la que todos fueran ciudadanos activos [...]. Una sociedad civil en la que todos tuvieran asegurado su derecho a la existencia, sin necesidad de dependencias patriarcales o neopatriarcales. Democracia era, pues fraternidad y fraternidad democracia” (Domenèch,...op.cit,p. 92).

${ }^{58}$ Como afirma Antoni Domènech: El sentido político más característico que cabe atribuir a la elusiva consigna política revolucionaria de «fraternidad» a partir de 1790[...] es éste: la plena incorporación a una sociedad civil republicana de libres e iguales de quienes vivían por sus manos, del pueblo llano del viejo régimen europeo. Y éste, el pueblo «propiamente dicho», como se decía entonces, estaba compuesto por una miríada de individuos excluidos en distintos grados de la vida civil, y socialmente regimentados bajo una gran variedad de formas de dominación y dependencia de terceros” (Domenèch, Antoni, El eclipse de la fraternidad, Crítica, Barcelona, 2004, p.74). 


\subsection{Fraternidad y derecho al trabajo en la II Republica}

\subsubsection{La Revolución de febrero: entre una República política y una República}

\section{social}

En enero de 1848 la Monarquía de Julio se encontraba al borde del precipicio. Una triple crisis había trastornado las condiciones de vida de casi toda Europa, en particular, las de las clases trabajadoras. A la crisis agrícola, producto de las malas cosechas de cereales y centeno, ${ }^{59}$ se sumaba la terrible resaca que dejó la borrachera especulativa en la industria ferrocarrilera ${ }^{60} \mathrm{y}$, como consecuencia de ambas, el estancamiento de la producción inglesa. En Francia, la crisis económica atizaba el fuego de un descontento social cada vez más amplio. Desde la década de 1830, Luis Felipe había establecido un sistema económico que privilegiaba a un pequeño grupo de banqueros mientras relegaba a segundo término a un amplio sector de la burguesía industrial. ${ }^{61}$ En materia política, la Monarquía descansaba sobre un régimen censitario absolutamente cerrado, el cual negaba los derechos políticos de 7 de cada 10 habitantes. No era de extrañar que el hartazgo de unos trabajadores fustigados por la crisis económica fuera acompañado por las aspiraciones de ascenso social de la pequeña burguesía industrial desdeñada por Luis Felipe. Sin embargo, los motivos del descontento no eran homogéneos.

De hecho, los primeros banquetes ${ }^{62}$ contra la Monarquía de Julio no fueron organizados para defender una República sino para exigir una reforma electoral destinada a ampliar los derechos de participación política en el marco de un sistema monárquico. Entre sus principales impulsores se encontraban Thiers y Odilon Barrot, ambos partidarios de una forma de sufragio censitario ampliada pero contrarios al sufragio universal. ${ }^{63}$ La inflexible

\footnotetext{
${ }^{59}$ Pouthas, Carles; Guirald, Pierre; et al. Democracia, reacción, capitalismo (1848-1860), Akal, Madrid, 1993, p.32.

${ }^{60}$ Ibid. p. 33. En La lucha de clases en Francia de 1848 a 1850, por ejemplo, Marx señala la connivencia entre la burguesía financiera francesa, las empresas de ferrocarriles y el poder político. En efecto, usualmente influyentes miembros de la Cámara compraban acciones de las empresas constructoras de ferrocarriles a las que ellos mismos terminaban asignando las obras (Marx, Carlos; Engels, Federico, Obras Escogidas I, Editorial Progreso, Moscú, 1977, p. 128).

${ }^{61}$ Ibid. p. 125 ss

${ }^{62}$ La campaña de los banquetes iniciada en 1847 fue un mecanismo ideado por los sectores más críticos de la Monarquía de Julio con el fin de eludir la prohibición del derecho de reunión. El 22 de febrero se celebraría el último banquete de la campaña a las afueras de París, sin embargo, el gobierno de Luis Felipe decidió prohibirlo ante el peligro que suponía esta reunión.

${ }^{63}$ Como cuenta Engels el 20 de noviembre de 1847 en el Num. 526 de The Northern Star, una de las principales discusiones previas al primer banquete tuvo que ver con el brindis que se llevaría a cabo en el mismo. La
} 
postura de François Guizot, ${ }^{64}$ entonces ministro del interior, ante las moderadas peticiones de los primeros banquetes preparó el terreno para la radicalización de las demandas políticas y, finalmente, para el ascenso de los partidarios de la República.

No obstante, una vez que la revuelta popular de febrero declaró el fin de la Monarquía, la disputa entre la búsqueda de una República política por parte del ala moderada y las demandas de los defensores de una República democrática y social marcó los derroteros del periodo revolucionario.

\section{El derecho al trabajo y los Talleres Nacionales}

A pesar de que los acontecimientos de febrero propiciaron un Gobierno Provisional favorable a los republicanos moderados, ${ }^{65}$ la distancia que los separaba de los sectores más radicales

cuestión se dividía entre quienes sugerían que se brindara por la salud del rey y quienes lo promovían que se hiciera en nombre la soberanía del pueblo (Marx, Karl; Engels, Friedrich, Los grandes fundamentos, FCE, México, 1988, p. 250).

${ }^{64}$ Guizot era un feroz combatiente de los republicanos y un acérrimo rival de la democracia, el historiador francés había sido uno de los líderes "liberales" de la oposición al gobierno de Carlos X en 1822; sin embargo, en 1848 llevaba ya ocho años asumiendo posturas cada vez más conservadoras en la dirección del gobierno de Luis Felipe. Guizot era enteramente consciente de que la Revolución de 1789 clausuraba el derecho divino como forma de legitimación del poder político, por lo que, desde su juventud, defendía la existencia de una condición previa y excluyente para participar de la soberanía popular (Wallerstein, Immanuel, El moderno sistema mundial IV. El triunfo del liberalismo centrista 1789-1914 Alianza, México, 2014, p.28). ¿Cuál era esa condición?, la posesión de una "capacidad" para gobernar basada en la "facultad de actuar de acuerdo con la razón”. Así, las decisiones políticas debían estar limitadas a un selecto grupo de personas que hacían las veces de "mano irresistible" de la razón en el curso de la historia. Esa mano lo había elegido a él para gobernar, pero no a la mayoría de trabajadores no propietarios de Francia y, he aquí lo verdaderamente trágico para la Monarquía de Julio, tampoco a los pequeños propietarios industriales y al campesinado de la época.

${ }^{65}$ La revuelta popular de febrero inició con la prohibición del banquete reformista planeada para el 22 de febrero. Sin embargo, la chispa de la insurrección fue el asesinato de 32 personas pertenecientes al pueblo por parte de los soldados del 14 regimiento de línea que resguardaban el ministerio de Asuntos Exteriores presidido por Guizot (Pouthas...op.cit. p. 41). La mañana del 24 París amaneció sublevado, hombres y mujeres de todas las edades levantaba barricadas por doquier dispuestos a enfrentarse a una Guardia Nacional que muy pronto abandonó la defensa de la monarquía. Luis Felipe no tuvo más opción que abdicar en favor de su nieto de 9 años y salir del país inmediatamente. Después de un complicado debate en el interior del Hotel de Ville se proclamó un Gobierno Provisional cuyos miembros habían sido elegidos "de antemano por el periódico Le National" (Ibid.p.42). un órgano del ala burguesa del partido republicano (Vigier, Philippe, La Seconde Republique, PUF, Paris, 2001, p. 8). Concretamente los nombres propuestos por Le National eran François Arago de La Réforme, reconocido científico; Lamartine, afamado poeta, diputado en la Monarquía de julio y autor del libro Histoire des Girondins; Marie, también diputado, abogado de la facción republicana en la Asamblea de la Monarquía de julio y conocido opositor de los socialistas; Garnier-Pagès y Marrast (Harsing, Jill, Barricades. The War of the Streets in Revolutionary Paris 1830-1848, Palgrave, New York, 2002, p.262). El 25 de febrero el reparto de los principales puestos políticos estaba decidido con una clara ventaja para los republicanos moderados. A pesar de ello, los trabajadores no se consideraron defraudados, ya que un representante de su clase-el obrero Albert- fue considerado para formar parte del gobierno y el periódico Réforme había presionado para incorporar a Ledru-Rollin. Además, en el último instante, el socialista Louis Blanc había sido considerado para formar parte de la institución que tomaría las riendas de la nueva Francia republicana. Para una narración detallada: Ibid. p. 268ss. 
sólo se haría visible con el paso del tiempo. En un primer momento el ánimo revolucionario inundaba hasta tal punto la capital francesa que resultaba difícil ignorar las demandas de las masas. La mañana del 25 de febrero el Gobierno Provisional decretó la libertad de prensa, la libertad de asociación y la elección -mediante sufragio universal masculino- de una Asamblea Nacional. A estos decretos debió agregarse una disposición que no había sido contemplada por los miembros del Hôtel de Ville, a saber: el derecho al trabajo. En realidad, fue sólo por la irrupción de una delegación de trabajadores a las instalaciones del Gobierno Provisional que sus miembros se vieron obligados a implementar medidas concretas destinadas a enfrentar la crisis de los trabajadores. Así, Lamartine, cabeza del órgano gubernamental, encargó a Louis Blanc la preparación de un decreto sobre los asuntos laborales. La redacción del socialista plasmaba fielmente las demandas que el movimiento asociacionista francés había venido construyendo desde la década de 1830:

El gobierno de la República Francesa se compromete a garantizar la existencia del obrero mediante el trabajo(c/n). Se compromete a garantizar el trabajo para todos los ciudadanos. Reconoce que los obreros deben asociarse para disfrutar de los beneficios legítimos de su trabajo(c/n). ${ }^{66}$

Sin duda, la promulgación de este decreto fue concebida como una victoria por parte de los trabajadores, con lo cual las dos inercias que motivaron la Revolución parecían encontrar un cauce común: el sufragio universal y el derecho al trabajo forjaban los cimientos de una República capaz de incluir a todos como sujetos de derechos políticos y como sujetos de un derecho destinado a garantizar su existencia material a través del trabajo. Sin embargo, este feliz matrimonio no duraría demasiado tiempo.

Aunque en plena embriaguez revolucionaria el Gobierno Provisional declaró solemnemente el derecho al trabajo y afirmó la necesidad de organizarlo en favor de las asociaciones obreras, ${ }^{67}$ las disposiciones que deberían hacer efectivas esas exigencias constituían un problema de primer orden. El 28 de febrero miles de trabajadores marcharon en dirección del Hôtel de Ville exigiendo la creación de un Ministerio del Trabajo dirigido por los propios obreros. Lamartine no cedió en este punto, pero ordenó el establecimiento de

\footnotetext{
${ }^{66}$ Citado en: Sewell, William, Trabajo y revolución en Francia. El lenguaje del movimiento obrero en Francia desde el Antiguo Régimen hasta 1848, Taurus, Madrid, 1992.p. 338.

${ }^{67}$ Vigier...op.cit. p. 19
} 
una Comission du gouvernement pour les travailleurs destinada a estudiar los medios para mejorar la situación de los trabajadores. ${ }^{68}$ De esta manera, los miembros más radicales del Gobierno Provisional -Blanc y Albert- fueron destinados al Palacio de Luxemburgo para presidir una Comisión encargada de dar solución a los problemas de los trabajadores de París. ${ }^{69}$

La Comisión de Luxemburgo decretó la reducción de la jornada laboral, reconoció el carácter legal de las corporaciones y las promovió en aquellos oficios donde no existían. Además, su presencia propició que decenas de obreros redactaran regulaciones para proponérselas a los empresarios, quienes preferían entrar en negociaciones con los delegados de la Comisión antes que enfrentarse a una huelga. ${ }^{70}$ Sin embargo, las medidas para enfrentar el desempleo no fueron diseñadas por los miembros de la Comisión, sino por los líderes del Gobierno Provisional. Así, mientras que en el Palacio de Luxemburgo Blanc abogaba por unos talleres del pueblo acordes a sus propuestas en La organización del trabajo, Marie, ministro del Gobierno Provisional, ${ }^{71}$ se encargaba de poner en marcha los famosos Talleres Nacionales, una medida que, en los hechos, se asemejaba más a los ateliers de charité, tradicionalmente usado por el Antiguo Régimen en situaciones de desempleo, ${ }^{72}$ que a las demandas de los republicanos sociales.

\footnotetext{
${ }^{68} \mathrm{Cfr}$. Vigier...op.cit. p.20. Donzelot recoge una versión más edulcorada que la de Marx en La lucha de clases en Francia: "Los testigos -afirma- cuentan cómo, empujado por sus camaradas, el obrero Marche ingresó, con la bayoneta calada en el fusil, al despacho de Lamartine, el gran hombre del momento y jefe de aquel gobierno provisorio, para exigirle "la organización del trabajo, el derecho al trabajo dentro de una hora". Sin duda el obrero Marche resultó fascinado por la retórica del escritor y la paciencia pedagógica de la que éste parece haber dado pruebas, pues al salir algunas horas después pronunció esta frase histórica. "El pueblo pone tres meses de miseria al servicio de la República” (Donzelot, Jacques, La invención de lo social, Nueva Visión, Buenos Aires, 2007, p.29).

${ }^{69}$ No obstante, en los hechos, esta Comisión carecía de la capacidad para influir de forma determinante en las decisiones del Gobierno Provisional. Así lo expone Proudhon en sus recuerdos de la revolución: "Los obreros no ignoraban que Luis Blanc y Albert no tenían ningún medio para realizar sus audaces proyectos, y que su influencia sobre el gobierno provisional era casi nula" (Proudhon, J.P. Confesiones de un revolucionario, Americalee, Buenos Aires, 1947, p.78). Por su parte Marx enfatiza la ausencia de poder ejecutivo y la falta de presupuesto de la Comisión (Marx, Engels, Obras escogidas 1...op.cit.140ss.).

${ }^{70}$ Sewell...op.cit. pp. 345-353.

${ }^{71}$ La sola elección de Marie para encargarse de los Talleres evidenciaba la postura de la mayoría del Gobierno Provisional. Marie era conocido por su repulsión al socialismo e incluso afirmó que "el objetivo que se había propuesto era el de demostrar las falacias del socialismo” (Palmer, R \& Colton, J, Historia contemporánea, Akal, Madrid, 1971, p. 217).

${ }^{72}$ Sewell,...op.cit.p.338. Cuando en La lucha de clases en Francia Marx criticó los Talleres Nacionales afirmando que no eran sino centros de caridad hacía referencia a esta situación (Marx; Engels, Obras escogidas 1...op.cit. p.141). Palmer, por su parte, señala que los Talleres no eran más que "un gran proyecto de ayuda para los parados” (Palmer, ...op.cit. p 271).
} 
En efecto, los ateliers fueron concebidos como instancias de asistencia para pobres y desempleados y no como un instrumento destinado a reorganizar el mundo del trabajo. Estos inmensos centros de asistencia albergaban a miles de desempleados parisinos otorgándoles un pago de dos francos diarios. Sin embargo, a excepción de unas cuantas obras urbanas poco rentables, la mayoría de ellos estaban destinados a labores inútiles. ${ }^{73}$ La dificultad incrementaba porque los obreros de provincia e incluso algunos extranjeros viajaban a París en busca de empleo. Así, las filas de este "ejercito obrero industrial"74 crecían de forma tan acelerada que, en menos de 3 meses, pasaron de 14 mil a 103 mil personas. ${ }^{75}$

Esta forma de implementar los Talleres Nacionales evidenciaba que la mayor parte de los integrantes del Gobierno Provisional no estaba dispuesta a asumir las consecuencias sociales ${ }^{76}$ que traería consigo el decreto del 25 de enero. ${ }^{77}$ Existía una razón de peso para ello: el derecho al trabajo había sido el resultado de las reivindicaciones de los movimientos de asociación laboral fraguados durante las dos décadas anteriores. Movimientos contra los cuales tanto el ala conservadora de la Monarquía orleanista, como el ala liberal y el republicanismo moderado se oponían fervientemente. En realidad, para estos sectores, la crítica a la institucionalidad política de la Monarquía de Julio no era extensiva al papel que jugaba el mundo del trabajo en el gobierno de Luis Felipe.

\footnotetext{
${ }^{73}$ Palmer, ...op.cit. p.217.

${ }^{74}$ En La lucha de clases en Francia de 1848 a 1851, después de criticar a la Guardia Móvil por considerarla un ejército diseñado para salvaguardar los intereses de los republicanos moderados, Marx afirma que el Gobierno también decidió rodearse de un "ejército obrero industrial" en referencia a los Talleres nacionales (Marx; Engels, Obras escogidas 1...op.cit. p.141). Sin lugar a dudas, el término de "ejército industrial de reserva” usado en el El Capital se inspira en esta consideración.

${ }^{75}$ Pouthas...op.cit. p. 87.

${ }^{76}$ Que el Gobierno Provisional haya pretendido darle un contenido material al derecho al trabajo a través de medidas asistencialistas es evidencia de ello. El caso de Lamartine es interesante, a pesar de ser contrario a las propuestas socialistas desde la década de 1840, era partidario de una República capaz de sacar a los trabajadores de sus miserables condiciones de vida. Sin embargo, en 1848 los hechos lo pusieron cara a cara con los trabajadores quitando de su cabeza la romántica imagen que se había hecho de ellos. Lamartine tenía una visión idealizada del trabajo artesanal, pero la realidad del movimiento obrero era muy distinta, al igual que sus exigencias. Por lo mismo, nunca se sintió cómodo con el contenido del derecho al trabajo redactado por un socialista como Blanc. Sin embargo, cuando se discutió la implementación de este derecho a la constitución en el otoño de 1848, ya con el movimiento obrero derrotado, fue uno de sus pocos defensores. El historiador Philippe Vigier afirma que existe una enorme polémica entre los historiadores sobre si el gobierno provisional alguna vez tuvo la intención de tomar en serio las consecuencias a las que debía llevar el derecho al trabajo. Sin embargo, afirma que el hecho de haber elegido a alguien como Marie, conocido por su rechazo a las ideas socialistas, para dirigir el Ministerio de trabajo da cuenta que el gobierno provisional no estaba dispuesto a llegar muy lejos en el proceso de restructuración de la sociedad (Vigier,...op.cit.p.21). .

${ }^{77}$ Palmer,...op.cit.p.217.
} 
De ahí que los Talleres Nacionales tuvieran poco que ver con las propuestas relativas a la organización del trabajo defendidas por el republicanismo social. ${ }^{78}$ Este último consideraba la restructuración de la esfera productiva como parte de un proyecto más amplio de reorganización social. ${ }^{79}$ En ese sentido, el derecho al trabajo articulaba las exigencias materiales de los desposeídos con las aspiraciones políticas del republicanismo. En el lenguaje de la época, esto quería decir que los ideales políticos de libertad e igualdad sólo eran posibles cuando se había atendido el elemento material de la fraternidad. Veamos.

\section{Fraternidad en 1848}

En los años que siguieron al 9 de termidor, el recuerdo del jacobinismo radical quedó reducido a una sola palabra: Terror. Tuvieron que pasar más de tres décadas para que el proyecto republicano-fraternal comenzara a remontar ${ }^{80}$ los estigmas de la desprestigiada ${ }^{81}$ figura de Robespierre. ${ }^{82}$ Durante la Revolución de 1830 cientos de asociaciones republicanas

\footnotetext{
${ }^{78}$ Sobre este punto el libro de Michael Piore y Charles Sable The Seconde Industrial Divide aporta una postura interesante. En él se afirma que, justamente, 1848 representó un punto de no retorno, ya que en ese año se perdió la oportunidad de organizar el trabajo en pequeñas empresas controladas por los trabajadores (Piore, Sable \&Sabel, Charles, The Seconde Industrial Divide, Basic Books, New York,1984)

${ }^{79}$ En su imprescindible estudio sobre el lenguaje del movimiento obrero William $\mathrm{H}$. Sewell afirma que: “[...] las implicaciones del decreto que proclamaba el derecho al trabajo iban más allá de un alivio al paro. Como lo interpretaron los obreros de París y otras ciudades de Francia, establecía el derecho al trabajo como un derecho humano fundamental. Además, el reconocimiento de ese derecho parecía implicar una restructuración radical de todo el orden social. La afirmación de que los obreros deben asociarse para disfrutar los beneficios legítimos de su trabajo suponía que estaban privados de ellos y que era necesaria la asociación [...] para resolver los problemas" (Sewell...op.cit.p. 339).

${ }^{80}$ En 1828, por ejemplo, se publicó La conspiración por los iguales de Babeuf, libro en el que se narraba el fallido intento de levantamiento contra el Directorio termidoriano ocurrido en 1796: frente al régimen de exclusión y privilegios que se había impuesto con la derrota jacobina, los conspiradores buscaban reinstaurar una República democrática y social. Al respecto véase la interesante introducción de Gareth Stedman Jones a la edición del Manifiesto Comunista del Fondo de Cultura Económica (Marx, Karl; Engels, Friedrich, El manifiesto comunista, FCE, México, 2007, p. 19ss.).

${ }^{81}$ Como señala David P. Jordan la leyenda negra de Robespierre inició con el informe de la Comisión de los Doce durante el gobierno termidoriano. El autor del documento, E. B. Courtois, entregó el informe el 5 de enero de 1795, después fue publicado por los termidorianos. Los primeros detractores de Robespierre se basaron en dicho documento para presentar la imagen de un individuo que traicionó a la clase de los "hombres decentes" intentando extinguir la riqueza y el comercio. De forma más que comprensible, los autores de la muerte de Robespierre querían legitimar la contrarrevolución termidoriana, cosa que en buena medida lograron con el informe Courtois (Jordan, David. P., Robespierre. El primer revolucionario, Javier Vergara Editor, Buenos Aires,1986, p. 25ss). Sin embargo, resultan menos comprensibles desde el punto de vista historiográfico las razones que llevaron a muchos historiadores del siglo XX a tomar como única fuente un texto a todas luces unilateral fabricado con fines políticos.

${ }^{82}$ En 1832, el socialista romántico Albert Laponneraye publicó la primera colección importante de discursos de Robespierre, abriendo paso a un estudio renovado sobre su pensamiento pues, hasta entonces, la única fuente asequible era el famoso informe Courtois.
} 
reaparecieron por toda Francia, una de las más relevantes fue la famosa Société des Droits de l’Homme et du Citoyen, integrada por viejos jacobinos, jóvenes republicanos y trabajadores urbanos. ${ }^{83}$ Desde finales de la década de 1820, los nuevos impulsos republicanos habían comenzado a tomar forma en las entrañas del incipiente movimiento obrero. Una vinculación que se intensificará gracias a los constantes embates represivos ${ }^{84}$ sufridos por los trabajadores a manos del gobierno monárquico de Luis Felipe. ${ }^{85}$

Como lo hicieron los jacobinos radicales en su momento, los republicanos sociales de 1840 no dudaron en criticar el despropósito de quienes osaban llamar libre ${ }^{86} \mathrm{e}$ igualitario a un régimen social que, además de no reconocer los derechos políticos del grueso de la población, mantenía a los trabajadores en una situación de miseria perpetua. Aunque se encontraba en un contexto distinto al de Robespierre, Saint Just o Marat, Auguste Blanqui recogía aquella crítica que denunciaba la falsedad de un régimen supuestamente igualitario en el que, sin embargo, sólo una minoría tenía derechos políticos. En un artículo publicado durante la década de 1830 en el periódico republicano Liberater, el francés señalaba:

Les Français sont égaux devant la lois ? Mais pourquoi donc sur trente-trois millions d'individus, cent mille seulement sont-ils en possession de leur droits politiques et existentils comme hommes et comme citoyens, tandis que le reste de Français est comme un vil troupeau ${ }^{87}$

Por su parte, Louis Blanc criticaba airadamente esa forma de libertad -defendida tanto por monárquicos liberales como por algunos republicanos moderados- que pasaba por alto las terribles condiciones materiales de los trabajadores:

\footnotetext{
${ }^{83}$ Cfr. Gonzáles, Jesús, “Libertad, igualdad, fraternidad en el socialismo jacobino” en: Anuario de Filosofía del Derecho, Madrid, 1989: 136.

${ }^{84} \mathrm{Al}$ respecto véase el libro de Jill Harsin, Barricades. The War of the streets in Revolutionary Paris, 18301848, en particular el capítulo dos titulado "Insurrections" (Harsin, Jill, Barricades. The War of the streets in Revolutionary Paris, 1830-1848, Palgrave, Nueva York, 2002).

${ }^{85}$ En ese contexto, la "Sociedad de los Derechos del Hombre y del Ciudadano" apremió "a los líderes obreros a que sacaran conclusiones políticas de la derrota; haciéndoles ver [...] que de la Monarquía no iban a recibir ningún apoyo”. De ahí que sus esfuerzos debían ser dirigidos a la instauración de una República cuya misión esencial "sería la de proporcionar a los trabajadores los medios necesarios para crear sus propias asociaciones de productores o cooperativas (c/n)" (Gonzáles,... op. cit. p. 136).

${ }^{86}$ No hay que olvidar que la llegada de Luis Felipe de Orleans en 1830 fue saludada con deferencia por los monárquicos liberales, frente al gobierno de Restauración encabezado por Carlos X. De hecho, en sus primeros años, Luis Felipe fue catalogado como un monarca liberal.

${ }^{87}$ Blanqui, Louis Auguste, Euvres I. Des origines à la Révolution de 1848, Presses Universitaires de Nancy, 1993, p.253.
} 
Oui, la liberté ! Voilà ce qui est à conquérir; mais la liberté vraie, la liberté pour tous, cette liberté qu'on chercherait en vain partout où ne se trouvent pas l'égalité et la fraternité [...] La liberté de l'état sauvauge n'était, en fait, qu'une abominable oppression, parce que elle se combinait avec l'inégalité de forces, parce qu'elle faisait de l'homme faible la victime de l'homme vigoureux [...] Or, nous avons, dans le régime sociale actuel, au lieu de l'inégalité de forces musculaires, l'inégalité de moyens de développement; au lieu de la lutte corps à corps, la lutte de capitale à capitale [...] au lieu de l'homme impotent, le pauvre, Où donc est la liberté? ${ }^{88}$

Así, de la misma manera que el jacobinismo radical había rechazado la falsa igualdad y la falsa libertad (moderna) promovida por una minoría deseosa de mantener sus privilegios de propiedad (privada ilimitada), tanto Blanqui como Blanc desdeñaban esa "libertad sin igualdad y fraternidad" que enmascaraba la sujeción a la que diariamente estaban sometidos los trabajadores en la Monarquía orleanista.

Sin embargo, a diferencia del jacobinismo de la primera República, ${ }^{89}$ los socialistas de 1840 eran testigos de un acelerado proceso de industrialización, un proceso que redefinía la composición urbana en formas hasta entonces insospechadas. ${ }^{90}$ El crecimiento de los talleres manufactureros y los centros de trabajo industrial, aunado a las procesos de desposesión de la propiedad comunal, convirtieron a las ciudades del siglo XIX en el caldo de cultivo de una nueva clase de hombres y mujeres ${ }^{91}$ obligados a empeñar su propia existencia para no engrosar las filas de la mendicidad y el vagabundeo. ${ }^{92}$ De ahí que el

\footnotetext{
${ }^{88}$ Blanc... op. cit. . p.17.

${ }^{89}$ El primer jacobinismo se hallaba especialmente interesado en limitar los privilegios de los propietarios de la tierra. Como afirma Joaquín Miras: "La sociedad europea que precede a la Revolución era una sociedad fundamentalmente feudal y mayoritariamente agraria. La actividad económica era desarrollada por pequeños productores directos que poseían los saberes técnicos que ordenan la producción, y que se organizaban conforme a sus propias tradiciones en gremios artesanos y en comunidades, tanto rurales como urbanas” (Miras, Joaquin, “La República de la virtud”, en: Bertomeu, María Julia, et.al (comp.) Republicanismo y democracia, Miño y Dávila editores, Buenos Aires 2004. p.148).

${ }^{90}$ Inglaterra había mostrado claramente el horizonte que le esperaba a Europa con estas transformaciones: el empobrecimiento generalizado de las clases trabajadoras, el desplazamiento obligado de los trabajadores del campo a la ciudad, la generalización del trabajo fabril y la explotación encarnizada de niños, mujeres y hombres (Cfr. Hobswan, Eric, La era de la Revolución 1789-1848, Crítica, Barcelona, 2003. p.34ss; Marx, Karl, El Capital. Tomo I. Volúmen 2, Siglo XXI, México, 2013.p. 409ss.; Lis... op. cit. ., p. 166ss.).

${ }^{91}$ Las novelas del siglo XIX nos otorgan un inmejorable testimonio del asombro provocado por la aparición de estos inquietantes individuos en las grandes urbes europeas. Desde el acercamiento ingenuo de Dickens en Tiempos difíciles hasta la descarnada descripción de Zola en Germinal, pasando por la idealización romántica de Victor Hugo o el desprecio de Flaubert en La educación sentimental, ningún retrato importante de las ciudades modernas podía pasar por alto a estos ineludibles personajes.

${ }^{92}$ Como afirma Antoni Domenèch: "De ser un fenómeno más o menos secundario en los albores del Antiguo Régimen, el trabajo «libre» asalariado se convirtió en una realidad sociológica que cobraba cada vez mayor peso. Un proceso secular proteico [...] cristalizó en unas pocas décadas [...] centenares de millones de personas
} 
republicanismo decimonónico no centrara su atención en la limitación de la propiedad agraria, sino en el establecimiento de nuevos mecanismos para contrarrestar los efectos del proceso industrial sobre esa creciente masa de individuos desposeídos. ${ }^{93}$

En efecto, sin ninguna regulación social y en ausencia de cualquier limitación jurídica, la dinámica interna del proceso de industrialización generaba un escenario de competencia perpetua entre los dueños del capital, que, además de impulsar a los patrones a bajar los salarios y aumentar la jornada laboral, ${ }^{94}$ impactaba negativamente sobre las condiciones de trabajo en el interior de los centros laborales. En uno de los capítulos más célebres de La organización del trabajo, Louis Blanc caracterizaba al "imperio de la competencia ilimitada” como el espacio en el que se perpetuaban las nuevas formas de dependencia de la modernidad industrial:

Mais qui donc serait assez aveugle pour ne point voir que, sous l'empire de la concurrence illimitée, la baisse continue des salaires est un fait nécessairement général [...]. La population a-t-elle des limites qu'il ne lui soit jamais donné de franchir ? Nous est-il loisible de dire à l'industrie abandonnée aux caprices de l'egoisme individuel, à cette industrie, mer si féconde en naufrages : Tu n'iras pas plus loin ?95

Y más adelante, con una retórica habitual entre los obreros de la época, agregaba:

fueron arrastrados a un gigantesco movimiento migratorio, desprendidas del campo, de la aldea, de la pequeña ciudad, de la familia, de vecinos y de amigos, del paisaje originario, de sus ancestros, de la parroquia y de la comunidad, para ser arrastrados, como forasteros, a los grandes centros industriales” (Domenèch,... op. cit.p. 97).

${ }^{93}$ Aunque ha pasado a la historia como una noción de origen marxista, la palabra proletario era usada desde las primeras décadas del siglo XIX en clara alusión a los “los proletarii de la Antigua Roma”, quienes, al igual que esta nueva clase de hombres y mujeres "no tenían otra cosa que ofrecer sino su fuerza de trabajo y (la de) su prole" (Ibid.).

${ }^{94}$ Cfr. Marx, Karl, El capital... op. cit. . 451ss. Ciertamente, el proceso de industrialización no convirtió a los desposeídos en trabajadores fabriles de forma inmediata. Hacia 1850 sólo el 3 por ciento de los empleados franceses se desempeñaba en una fábrica (Lis,... op. cit. . p. 180). En su gran mayoría, los asalariados eran trabajadores de oficio cuya vida laboral se desarrollaba en talleres, manufacturas o en la industria doméstica. Esta circunstancia, sin embargo, aumentaba su resistencia a las nuevas dinámicas laborales. Acostumbrados a la "honorabilidad" que otrora les brindaba su carácter de artesanos, los trabajadores franceses resentían como pocos las nuevas transformaciones en las dinámicas laborales. En un principio, las mujeres y los niños fueron los más afectados por ese proceso, como los hombres adultos preferían mantener la "honorabilidad" de sus oficios artesanales a trabajar en la fábricas, los propietarios acudieron a la mano de obra de mujeres y niños, una mano de obra cuyo coste era considerablemente menor (Lis,... op. cit. . p.182). En El Capital. Marx explica este mismo fenómeno como uno de los efectos de la maquinaria sobre la clase obrera, llamándolo: “Apropiación de fuerza de trabajo subsidiaria por el capital” (Marx... op. cit. . p. 489).

95 Blanc... op. cit. . 32 
Une machine est inventée ; ordonnez qu'on la brise, et criez anathème à la science ; car, si vous ne le faites, les mille ouvriers que la machine nouvelle chasse de leur atelier iront frapper à la porte de l'atelier voisin et faire baisser les salaires de leurs compagnons. Baisse systématique des salaires, aboutissant à la suppression d'un certain nombre d 'ouvriers, voilà l’inévitable effet de la concurrence illimitée. ${ }^{96}$

Fue ante esta realidad que, en la década de 1830, los trabajadores comenzaron a utilizar la palabra “explotación” para denunciar el trato deshumanizante que recibían en el taller y la fábrica. Lejos de ser reconocidos como seres humanos que aportaban su trabajo para aumentar la riqueza social, los obreros consideraban que su cuerpo era utilizado como un “factor de producción” más que, como los metales o las tierras, podía ser "explotado” libremente. ${ }^{97}$ Durante esos años era frecuente encontrar escritos como éste, publicado en L’Artisan, el periódico de los obreros franceses:

Que quelques journalistes se renfermant dans leur petite bourgeoisie aristocratique s'obstinent à ne voir dans la classe ouvrière que des machines produisant pour leurs seuls besoins [...]. Mais nous ne sommes plus au temps où les ouvriers étaient desserfs qu'un maître pouvait vendre ou tuer à son aise ; nous ne sommes plus à cette époque si peu éloignée où notre classe ne comptait dans la société que comme le bras du corps social [...]. Cessez donc, ô nobles bourgeois, de nous repousser de votre sein, car nous sommes aussi des hommes et non point des machines. Notre industrie, que vous exploitez depuis si longtemps, nous appartient en propre et les lumières de l'instruction, le sang que nous avons répandu pour la liberté nous ont donné les moyens et le droit de nous affranchir à jamais de la servitude où vous nous teniez. ${ }^{98}$

De esta forma, la exigencia de ser reconocido como seres humanos libres comenzaba a entrecruzarse con la crítica al "imperio de la competencia ilimitada”. Desde la perspectiva de los obreros, el deterioro de las condiciones salariales ${ }^{99}$ y la ausencia de controles en el taller y la fábrica ${ }^{100}$ los colocaba en una situación de dependencia más cercana a la

\footnotetext{
${ }^{96}$ Ibid. p. 33.

${ }^{97}$ Sewell... op. cit. . 279.

98 Texto recopilado en: Faure, Alain et Rancière, Jacques, La parole ouvrière, La fabrique, Paris, 2009, pp.159160.

99 En el Manifiesto del partido comunista que, por lo demás, muestra bastante bien la situación de los trabajadores de la época, se registra este hecho: "La condición de existencia del capital es el trabajo asalariado. El trabajo asalariado descansa exclusivamente sobre la competencia de los obreros entre sí” (Marx Karl; Engels Friedrich, Manifiesto... op. cit. p. 167).

${ }^{100}$ Cosa que igualmente registran Marx y Engels en el Manifiesto: “Masas de obreros, hacinados en la fábrica, son organizadas de forma militar. Como soldados rasos de la industria, están colocados bajo la vigilancia de toda una jerarquía de oficiales y suboficiales. No son solamente esclavos de la clase burguesa, del Estado burgués, sino diariamente, a todas horas, esclavos de la máquina, del capataz y, sobre todo, del burgués individual. Patrón de la fábrica” (Ibid. p. 163).
} 
servidumbre que a la libertad. ${ }^{101}$ Ante lo cual, la única forma de salvaguardar su dignidad frente a los abusos de los patrones era la asociación entre los trabajadores. Así, en 1833, Efhrem, un obrero dedicado a la zapatería escribía:

Nous qui souffrons, ne comptons que sur nous-mêmes, nous sentons le mal, cherchons un remède immédiat et efficace; appliquons-le. Je crois que nous le trouverons dans l'association. Cette idée, sainement comprise et sagement appliquée, produira, je pense, d’heureux résultats. ${ }^{102}$

Aunque no existía un consenso respecto a las modalidades que las asociaciones de trabajo debían adoptar ${ }^{103}$ era claro que sin ellas resultaba imposible enfrentar las formas de dependencia que "el imperio de la competencia ilimitada" le había impuesto a los obreros. Sin embargo, si en la década de 1820 los grupos fourieristas y saint-simonianos mostraron el potencial emancipador del asociacionismo, fue la tradición del republicanismo revolucionario la que enmarcó esa evidencia en un proyecto político coherente. Un proyecto que, fiel a la tradición ilustrada, echaba mano del lenguaje del derecho natural ${ }^{104}$ para buscar la realización de sus objetivos sociales. Así, lejos apelar a la benevolencia del "noble burgués”, el movimiento obrero ${ }^{105}$ comenzó a exigir el respeto a sus “derechos” para lograr el reconocimiento de su propia humanidad.

101 Como veremos, esta doble dependencia no respondía a la falta de "humanidad” de la nueva burguesía industrial, más bien era la consecuencia inevitable de una forma de organización social sostenida en la existencia de una nueva realidad: el mercado de trabajo. Una realidad que, como mostrará Karl Polanyi muchos años después, se volvía tanto más perniciosa cuanto carecía de cualquier limitación jurídico-política En cierto sentido, la modernidad capitalista no se caracteriza tanto por la generalización del mercado de bienes, como por el hecho de que ésta generalización sólo fue posible gracias a la irrupción de un mercado de trabajo. Los efectos inmediatos de esta irrupción no fueron nada alentadores, al menos no lo fueron para la clase trabajadora: pauperización, migración colectiva, disciplinamiento del trabajo, ruptura de todas las formas de organización social precedentes, por mencionar sólo las más importantes. Como afirma Domenèch, por la irrupción del mercado de trabajo: "[los obreros] estaban forzados a competir [...] con otros compañeros de desgracia a la hora de aceptar un precio para su fuerza de trabajo; [en ese mismo mercado se hallaba] la realidad de la disciplina absolutista de la fábrica, por la que se veían forzados a someterse, durante largas horas de extenuante e insalubre prestación de servicios, a las órdenes de superiores jerárquicos (Domenèch,... op. cit. p. 97).

102 Texto recopilado en: Faure...op.cit,.p.118.

${ }^{103} \mathrm{Ni}$ sobre al grado de participación que debía tener el Estado o sobre las condiciones de la competencia mutua (Cfr.Harvey... op. cit. p. 99ss).

104 Jaques Donzelot, por ejemplo, señala que la estrategia discursiva del ala izquierda de los republicanos consistía en retomar el esquema argumentativo de 1789. Así, a los privilegios convencionales de unas minorías debían oponerse los derechos naturales inherentes a todos los seres humanos (Donzelot, Jacques, La invención de lo social, Nueva visión, Buenos Aires, 2007, pp.28ss). Un análisis detallado de la importancia del derecho natural en la tradición de la Revolución francesa puede localizarse en: Gauthier, Florence, Triomphe et mort de la Révolution des droits de l'homme et du citoyen, Syllepse, Paris, 2014, p.27ss.

${ }^{105}$ Aunque parezca chocante, en ese contexto la asociación colectiva se presentaba como la única forma de garantizar la libertad individual de los obreros, mientras que, paradójicamente, aquello que la impedía era 
Después de las huelgas de 1833, la monarquía de Luis Felipe prohibió cualquier forma de organización por parte de los trabajadores. Ante lo cual, la respuesta de los mutualistas ya no apelaba a los bondadosos sentimientos de sus patrones, sino que exigía el cumplimiento de sus derechos naturales:

Considerando como tesis general que la asociación es un derecho natural (c/n) de todos los hombres, que es la fuente de todo progreso.

Considerando, en particular, que la asociación de trabajadores es una necesidad de nuestra época, que es una condición de existencia...

En consecuencia, los mutualistas protestan contra la ley liberticida de asociaciones y declaran que nunca inclinarán la cabeza bajo ese yugo arbitrario y que sus reuniones no se suspenderán nunca. Basados en el derecho más inviolable, es decir, a vivir trabajando resistirán con toda la energía que caracteriza a los hombres libres. ${ }^{106}$

No obstante, la represión de los obreros orquestada por Luis Felipe durante toda la década de 1830 dejó bastante claro que el régimen de la monarquía orleanista no estaba dispuesto a cumplir las exigencias de los obreros. Muy pronto, éstos comprendieron que no habría ningún cambio en sus condiciones materiales de vida sin transformar previamente los cimientos de la institucionalidad política. Así, la soberanía popular volvió a estar en el centro del debate. ${ }^{107}$ El planteamiento del republicanismo radical era simétricamente opuesto al defendido por Constant unos años atrás. Para aquellos, la mal llamada "libertad de los

precisamente eso que tanto miembros de la monarquía orleanista, como algunos republicanos moderados llamaban libertad. Esta aparente contradicción ha llevado a las más terribles confusiones dentro de los debates de filosofía política. Es preciso mostrar que, si los obreros elogiaban la asociación y la colectividad en el siglo XIX, al tiempo que desdeñaban el individualismo, no era por una especie de primacía del todo sobre las partes u otro de los tantos lugares comunes usados como fórmulas por cierta filosofía política enteramente desarraigada de los procesos históricos. Si los obreros criticaban la libertad individual ofrecida por liberales monárquicos y republicanos moderados, era simplemente porque, en ese contexto, eso a lo que ellos llamaban libertad individual era al dispositivo que perpetuaba la dependencia de los trabajadores al mercado de trabajo.

${ }^{106}$ Sewell... op. cit. . p. 371. Llama la atención que los mutualistas defendieran el derecho de asociación laboral en los términos de una "necesidad de nuestra época”. En realidad, parecían tener muy claro que la defensa de ese derecho no dependía de la prioridad de lo colectivo sobre lo individual, sino de las exigencias que imponía la industrialización capitalista, en cuyo seno la ausencia de un derecho (colectivo) de organización laboral impedía gozar de libertad (individual).

107 Donzelot afirma que para el discurso republicano de la época la cuestión de la legitimidad del soberano se hallaba estrechamente ligada al funcionamiento del orden social, de ahí que la perpetua negativa a ampliar los derechos políticos a todos los ciudadanos no fuera interpretada sino como un óbice para alcanzar la naturalidad de ese orden. En algún sentido, la soberanía popular había sido construida por el discurso republicano como el orden natural y, por tanto, legítimo de la organización política, de manera que las restricciones a los derechos civiles impuestas por Luis Felipe se leían como la utilización selectiva del derecho para impedir la organización del trabajo entre los sectores más populares. De hecho, esas restricciones impedían el traslado definitivo de la soberanía al pueblo y, con él, su capacidad de organización para acabar con los privilegios de las minorías (Donzelot...op.cit. p. 30ss). 
antiguos” se presentaba como la única vía para que "la libertad de los modernos” se ampliara a las clases populares. La ausencia de derechos políticos era interpretada como la ausencia de instrumentos para combatir esas formas de dependencia que restringían su libertad (antigua y moderna) en el mundo del trabajo.

En uno de los muchos panfletos escritos en la época, Marc Dufraisse impelía los obreros a comprender que sus exigencias en materia social sólo podían ser llevadas a cabo una vez que modificaran las estructuras políticas de la Monarquía:

\begin{abstract}
¿Cómo queréis alcanzar el bienestar mientras la aristocracia burguesa y financiera sea la única soberana?... Hace falta, para mejorar definitivamente la condición del pueblo, que ése recobre el ejercicio de su soberanía... Entonces el gobierno, propiedad del pueblo, instrumento de los deseos, de los intereses y de las necesidades, no de una fracción de privilegiados, de una minoría de egoístas, sino de todos; el gobierno, centro de una vasta asociación, agrupando alrededor de él todos los brazos y todas las inteligencias, protector de los derechos del pueblo y apoyándose en él, se comprometerá a liberar al proletario. Florecerán las asociaciones de trabajadores, os proporcionará los fondos necesarios para crear vuestros establecimientos. ${ }^{108}$
\end{abstract}

De igual forma, en La Organización del trabajo Louis Blanc mostraba que las propuestas concernientes a la llamada question social ${ }^{109}$ eran impracticables sin la supresión de toda forma de gobierno fundada en la defensa de privilegios minoritarios (question politique):

[...] est nécessaire de s'occuper d'une réforme sociale ; il ne l'est pas moins pousser à une réforme politique. Car si la première est le but, la seconde est le moyen [...]. Nous voulons un gouvernement fort, parce que, dans le régime d'inégalité où nous végétons encore, il y a des faibles qui ont besoin d'une forcé sociale qui les protège. ${ }^{110}$

108 Citado en: Gonzáles... op. cit. p. 137-138.

${ }^{109}$ Lo mismo valía para todos aquellos que se consideraban demócratas en Francia antes de 1848.

${ }^{110}$ Blanc, Louis....op.cit. p. 14-17. La vinculación existente entre la cuestión social, la organización del trabajo y la búsqueda de un Estado republicano no era exclusiva de Blanc, sino que expresaba las aspiraciones de la inmensa mayoría de quienes se consideraban demócratas en esa época. Esto no era casual, respondía a razones históricas bastante concretas, quizá la más relevante de ellas era que en el imaginario de los parisinos resultaba prácticamente inevitable establecer una relación causal entre las miserables condiciones de vida de la mayoría de los trabajadores y la constatación de que era esa mayoría la que carecía de derechos políticos. No es difícil entender el razonamiento que pretendía ligar la incorporación de todos los ciudadanos a la esfera política con la mejora de sus condiciones materiales de existencia; sin embargo, el convencimiento de que esa mejora sólo era plausible a través de la implementación de un derecho al trabajo evidencia que las reivindicaciones del incipiente movimiento obrero francés no eran ajenas al lenguaje jurídico y a la confianza en la ley heredadas de la ilustración. Los trabajadores no depositaban las esperanzas de transformar sus terribles condiciones de existencia en un indeterminado poder revolucionario, sino en una institucionalidad política capaz de garantizar cambios sociales mediante la implantación de derechos. Que esa institucionalidad sólo fuera posible gracias a 
La asociación de los trabajadores dependía, por tanto, de la modificación del orden político. De tal suerte que, si los obreros deseaban lograr su total independencia material, debían luchar por transferir el poder político de las élites burguesas a las masas trabajadoras. No obstante, esto implicaba modificar las estructuras del Estado, pasando de una Monarquía a una República democrática.

En la edición de 1847, un año antes de encontrarse en el Gobierno provisional, Blanc contestaba a las críticas realizadas por Lamartine quien llamaba tiránicas a las propuestas vertidas en La organización del trabajo:

[...] nous demandons que l’État -lorsqu'il serai démocratiquement constitué (c/n)- crée des ateliers sociaux, destinés à remplacer graduellement et sans secousse les ateliers individuels; nous demandons que les ateliers sociaux soient régis par des status réalisant le principe d'association et ayant forme et puissance de la loi. Mais, une fois fondé et mis en mouvement, l'atelier social se suffirait à lui-même et ne releverait plus de que son principe ; les travailleurs associés se choisiraient librement, après la première année des administrateurs et des chefs ; ils feraient entre eux la répartition des bénéfices ; ils s'occuperaient d'agrandir l'entreprise commencée... Où voit-on qu'un pareil système ouvre carrière à l'arbitraire et à la tyrannie? ${ }^{111}$

En la antesala de la revolución de febrero, el republicanismo social había comprendido que la batalla por mejorar las condiciones materiales de los trabajadores era inseparable de la lucha por establecer una República democrática. Sin embargo, como hemos visto, en su gran mayoría, los impulsores de los banquetes reformistas no eran participes del sufragio universal. El 29 de noviembre de 1847, Engels se esforzaba en explicar a los ingleses las diferencias existentes dentro del movimiento reformista francés:

“¿Pero qué clase de reforma se exigen”, preguntarán ustedes, las propuestas de reformas difieren tanto como pueden diferir entre sí los matices del liberalismo y el radicalismo (c/n). La exigencia mínima [defendida por los liberales] es la de que el derecho de sufragio se extienda a las capacidades -los que en Inglaterra tal vez llamarían ustedes la gente académica-, aunque no paguen los 200 francos de impuestos directos, que son hoy un requisito para poder votar. Los liberales, además, comparten más o menos con los radicales otras propuestas... ${ }^{112}$

una Revolución era algo distinto, una circunstancia que la evidencia de los hechos les había impuesto durante todo el siglo XIX.

${ }^{111}$ Blanc, Louis...op.cit.p.15

${ }^{112}$ Engels, Friedrich, "El movimiento en pro de la reforma en Francia" en: Marx, Karl; Engels, Friedrich, Los grandes fundamentos II, FCE, México, 1988. p. 253. 
Tal como lo señala Engels, ${ }^{113}$ el ala liberal del orleanismo exigía la ampliación del sufragio a un grupo limitado de personas consideradas capaces, o, en el mejor de los casos, apostaba por la reducción de la renta necesaria para poder votar. En sentido estricto, esto significaba que los liberales se daban por satisfechos con una reforma que ampliara el derecho de participación política para los círculos intelectuales y la pequeña burguesía. ${ }^{114}$ Los sectores radicales, en cambio, no sólo exigían el sufragio universal, sino que veían en la ampliación de derechos políticos un instrumento de primer orden para enfrentar los estragos del "imperio de la competencia ilimitada". 115

En uno de los pocos banquetes organizados por los demócratas antes de la Revolución de febrero, el periodista del periódico Le Réforme, Ferdinand Flocon, colocaba sus reflexiones en una línea de continuidad con la Declaración de Derechos del Hombre y del Ciudadano promovida por Robespierre en 1793:

Aquí a nuestro lado, la democracia, con sus veinticinco millones de proletarios ${ }^{116}$ a los que tiene que liberar y a los que da la bienvenida con los nombres de ciudadanos, hermanos,

113 Engels utilizaba la palabra liberal en el sentido habitual de la época. En lo que corresponde a los derechos políticos, este sentido era el mismo en Inglaterra, Alemania, Austria y España. Al menos hasta principios del siglo XX cuando el liberalismo británico, antes monárquico constitucional y antidemocrático, debió virara hacia la democracia, cosa que ni los nacional-liberales alemanes, ni el partido liberal austriaco, ni los liberales españoles hicieron sino muy tardíamente (Domenèch,... op. cit. p. 163).

${ }^{114}$ Así, aquella hipótesis que se esfuerza en identificar el origen de nuestras democracias “modernas” con el liberalismo político debe ser entendida, cando menos, como una interpretación selectiva de los hechos históricos. Al menos en Europa, desde finales del siglo XVIII, la irrupción del jacobinismo radical derivó en la vinculación del concepto de democracia con la lucha contra las más diversas formas de dependencia material. Precisamente por ello, tanto los sectores conservadores, como los liberales se oponían de forma declarada a la democracia. Por un lado, suponían que la extensión de los derechos políticos a las clases dependientes aumentaba la representación política de aquellos de quienes éstos dependían y, por el otro, consideraban que la irrupción de los trabajadores a los puestos de representación política amenazaba las bases mismas de la propiedad.

115 Ahora bien, esta vinculación entre las aspiraciones democráticas y las necesidades sociales del trabajo no era un invento francés. Más bien era el sentido habitual que tenía la lucha democrática en Europa en la primera mitad del siglo XIX. Desde 1830, el movimiento cartista, compuesto principalmente por trabajadores industrializados, encabezaba las exigencias democráticas en Inglaterra (Morton. A.L.; Tate, George, Historia del movimiento obrero inglés, Editorial Fundamentos, Madrid, 1971, p. 71ss.) Como señala Muniesa: “La palabra cartismo define a un amplio movimiento social y político que postuló una recogida de centenares de miles de firmas, al parecer alcanzaron hasta dos millones de ellas, desplegado en Inglaterra a principios de la década de 1830. Las firmas apoyaban una Carta en la que se exigía al Gobierno el derecho de voto para los trabajadores” (Muniesa, Bernat, Libertad, liberalismo, democracia, El Viejo Topo, 2008, p. 40). Sin duda, en el imaginario de la época, los trabajadores pensaban que su irrupción en la soberanía popular les permitiría enfrentar las disposiciones que perpetuaban su dependencia material.

${ }^{116}$ En su uso regular durante las décadas de 1830 y 1840 la palabra proletario se refería a todos aquellos que se encontraban en situación de dependencia, sin importar su adscripción o no a una forma de trabajo específica. Así, por ejemplo, Blanqui señalaba a mediados de la década de 1830: "Nous donnons le nom de prolétaires aux 
hombres iguales y libres (c/n); allí la oposición bastarda con sus monopolios y su aristocracia del dinero. Ellos hablan de reducir a la mitad el censo de la fortuna necesario para votar. ¡Nosotros, por nuestra parte, proclamamos los Derechos del Hombre y del Ciudadano! ${ }^{117}$

Pero en el contexto de la industrialización capitalista la amalgama entre los derechos políticos y la lucha contra las más diversas formas de dependencia ${ }^{118}$ ya no era formulada en los términos de un derecho a la existencia sino en la clave de un derecho al trabajo. De ahí que, durante los primeros meses de la II República, los obreros impulsaran esta demanda como un instrumento jurídico destinado, a la vez, a la consolidación de una República democrática y a la transformación de sus condiciones materiales de vida:

Nous voulons -nous, les travailleurs, nous qui non seulement sacrifions notre vie pour la défense des droits de la nation, mais qui subissons encore la misère dans ce qu'elle a de plus tyrannique, de plus implacable, de plus incessant- nous voulons, disons-nous, que rien de ce que nous produisons ne nous soit enlevé, nous voulons que ce mot : DROIT AU TRAVAIL inscrit sur les proclamations devienne une réalité. ${ }^{119}$

Entusiasmados por la aparente victoria del republicanismo social y por la creación de la Comisión de Luxemburgo, cientos de obreros comenzaron a crear sus propios documentos con propuestas para materializar el derecho al trabajo. Aunque divergían en sus matices, la gran mayoría de estos escritos apostaban por fomentar la asociación de productores:

De aquí en adelante -se afirmaba en uno de los documentos-, todas las empresas industriales, todos LOS TRABAJADORES DE AMBOS SEXOS, jornaleros, obreros, capataces, ingenieros, empleados, directores, estarán ASOCIADOS. ${ }^{120}$

Y otro más defendía que sólo era posible lograr:

[...] la abolición de la explotación del hombre por el hombre mediante la inmediata asociación de productores, mediante la creación de talleres asociados. ${ }^{121}$

ouvriers et aux paysans francais, parce que nous ne voyons nulle différence entre leur condition et la condition des proletaires romains, parce qu'ils supportent toutes les charges de la société, sans jouis d'aucun de ses avantages” (Blanqui...op.cit.p.253).

117 Engels, Friedrich, “Crónica política de Francia”, citado en: Marx, Karl; Engels, Friedrich, Los grandes... op. cit. p. 269.

118 Formas que, como hemos visto, ahora habían sido desplazadas al mundo del trabajo asalariado. A pesar de que las formas de dependencia patriarcal del Antiguo Régimen parecían haber sido abolidas gracias al derecho, las formas de dependencia patronal no sólo se mantenían intactas, sino que se presentaban como intocables por el derecho.

119 Texto recopilado en: Faure...op.cit.p.223.

${ }^{120}$ Citado en: Sewell, William, Trabajo...op.cit. p.344.

121 Ibid. 
Así, en sus diversas propuestas, el derecho al trabajo era concebido como el instrumento jurídico que permitía la cristalización del sueño democrático fraternal. Un sueño que se había extendido a casi todos los sectores “de izquierda” de la época. En 1847, por ejemplo, Marx fue nombrado Vicepresidente de “La Sociedad Democrática para la Unión y Cofraternización de los pueblos”, ${ }^{122}$ un organismo que, a su vez, estaba relacionado con la asociación inglesa “Fraternal Democrats”, ambas partidarias de la lucha por la emancipación de los trabajadores y la búsqueda de una República democrática. ${ }^{123}$ De igual forma, durante el Gobierno Provisional de la II República los ebanistas se organizaron en una “Asociación fraternal y democrática de ebanistas”, la cual reivindicaba “el gran principio de Fraternidad” consistente en "la igualdad de derechos para todos sin distinciones (c/n)". ${ }^{124}$ Por su parte, la quinta edición de la L'Organisation du travail de Louis Blanc fue publicada por la Sociedad de la Industria Fraternal, una asociación republicana que pugnaba por un gobierno democrático dispuesto a liberar a los trabajadores de sus ataduras materiales. Los ejemplos podrían proseguir indefinidamente.

En cualquier caso, la unión entre los conceptos de democracia y fraternidad mostraba que la verdadera confrontación de la época no tenía lugar entre los partidarios de una libertad “moderna” y “negativa” y los promotores de un concepto de igualdad radical vinculado a una idea de libertad “antigua” y “positiva”. Antes al contrario, en el centro de la discusión se hallaban dos formas distintas de concebir las atribuciones jurídico-políticas de la República: una absolutamente renuente a extender el derecho a la esfera de lo social y otra cuya pretensión era hacer de las instituciones republicanas instrumentos para acabar con la dependencia material.

\footnotetext{
${ }^{122}$ Por lo menos hasta 1850, Marx iniciaba cada uno de sus mensajes a la Liga comunista dirigiéndose a los miembros con la palabra "hermanos".

${ }^{123}$ Al final del Manifiesto comunista se puede leer: "Los comunistas, por último, trabajan en todas partes por la unión y el entendimiento de los partidos democráticos en todo el mundo” (Marx, Karl, El manifiesto...op.cit.). Dicho sea de paso, el comunismo surgió en Francia como una corriente ultra radical del republicanismo, la cual se identificaba con el jacobinismo por su énfasis en la igualdad.

${ }^{124}$ Sewell...op.cit. p. 357.
} 


\title{
1.3. Adiós al derecho al trabajo: la derrota del republicanismo social
}

\author{
Como vimos, el decreto para la implementación del derecho al trabajo del 25 de enero parecía \\ consumar el matrimonio entre la questión politique ${ }^{125}$ y la question social. Aunque los
} Talleres Nacionales no respondían a las expectativas del movimiento asociacionista, ${ }^{126}$ la legislación laboral impulsó la creación de corporaciones republicanas organizadas al amparo de la Comisión de Luxemburgo. Éstas fueron capaces de implementar mecanismos democráticos de asociación ${ }^{127}$ que les permitieron luchar para mejorar su posición en la relación con los patrones. Como señala Sewell, tan pronto como comenzaron a formarse las nuevas corporaciones republicanas:

125 Transformada ahora en questione democratique. De hecho, el lazo entre la democracia y la cuestión social era tal que un demócrata convencido como Louis Blanc incluso se planteaba la posibilidad de que el Gobierno provisional actuara dictatorialmente con el fin de transformar las condiciones sociales para allanarle el camino a una verdadera democracia. Esto se entiende muy mal si se aborda desde las coordenadas conceptuales del siglo XX, sin embargo, antes de que los terribles totalitarismos del siglo XX le otorgaran otro significado, la palabra dictadura conservaba el sentido que el derecho romano le había conferido: una dictadura era un gobierno extraordinario implementado en situaciones de crisis (no parecía haber un gobierno más extraordinario que el Gobierno provisional). Su finalidad consistía en recobrar el cauce de la normalidad institucional y, generalmente, no podía superar los seis meses de duración. A diferencia de las dictaduras autoritarias y unipersonales del siglo XX, los dictadores romanos eran impuestos bajo el mandato de los representantes del pueblo en el Senado. Ahora bien, para Blanc se trataba de saber qué tipo de poder le había otorgado el pueblo francés a esos hombres del Hôtel de Ville cuando los hizo agentes del Gobierno Provisional: "Apenas surgido de la aclamación popular, el gobierno provisional había tenido que preguntarse cómo se definiría. ¿Se consideraba una autoridad dictatorial, consagrada por una revolución que se había hecho necesaria, y no teniendo que dar cuentas al sufragio universal más que después de haber hecho todo el bien que había que hacer? ¿Limitaría, al contrario, su misión a convocar inmediatamente la Asamblea nacional, encerrándose en las medidas de urgencia, en actos de administración de un alcance secundario?” (Proudhon, J.P., Las confesiones..., p. 80). Toda la discusión se centraba en definir para qué había sido realizada la Revolución. Si su único objetivo era transformar las estructuras políticas de Francia, el Gobierno Provisional debía llamar inmediatamente a una Asamblea Nacional con el fin de cubrir los requisitos necesarios para instaurar un Estado republicano; pero si la Revolución también había sido emprendida para transformar las estructuras sociales, era necesario que los miembros de ese Gobierno -cuya autoridad provenía del mandato popular- iniciaran un proceso de reformas destinado a remover las bases de una sociedad profundamente desigual. De esta manera, cuando llegara el momento de constituir la Asamblea Nacional, ésta podría elegir transitar en el camino allanado por la autoridad dictatorial o, si el pueblo así lo decidía, abortarlo definitivamente. Justamente este era el razonamiento de Blanc: “... habríamos debido postergar lo más posible las elecciones: [...] se nos había mandado tomar, en ese intervalo, y eso altamente, atrevidamente, salvo el responder de ello con nuestras cabezas, la iniciativa de vastas reformas a realizar, dejando a la Asamblea nacional el derecho de reafirmar luego o derribar nuestra obra con mano soberana” (Proudhon...op.cit.p.80).

${ }^{126}$ Lo cual, desde luego, no evitaba que la mayoría de los obreros defendiera esa medida, sobre todo, los que habían caído en el desempleo por la reciente crisis de 1847 y quienes migraban del campo por las terribles cosechas o los estragos de la industrialización.

127 "Las corporaciones constituidas por los obreros en la primavera de 1848 -afirma Sewell- eran democráticas y republicanas en su estructura. Abarcaban a todos los obreros del ramo y estaban gobernadas por procedimientos democráticos. Todos los cargos o los delegados se elegían mediante el sufragio universal dentro del ramo [...] Unidades de un orden social republicano, las corporaciones obreras se configuraron en la forma de pequeñas repúblicas con sufragio universal y gobierno representativo como modo de actuación" (Sewell...op.cit.p.351). 
[...] empezaron a presionar a los a los maestros en favor de acuerdos públicos que garantizaran horarios más cortos, el control sobre la contratación, regulaciones de las condiciones de trabajo y sobre todo salarios más elevados y más uniformes -a veces en forma de un salario diario fijo, pero con más frecuencia en forma de tarifas-. ${ }^{128}$

En alguna medida, estas organizaciones comenzaron a poner en entredicho las dos formas de dependencia instauradas por el proceso de industrialización: el despotismo patronal y la competencia ilimitada. Por ello, cuanto más se normalizaba el reconocimiento legal de las asociaciones por parte de la Comisión de Luxemburgo, más aumentaba el desprecio hacia la misma por parte de los propietarios industriales de Francia.

Cuando la Asamblea Constituyente -compuesta mayoritariamente por exmonárquicos y republicanos moderados-, ${ }^{129}$ se reunió por primera vez en mayo de 1848, no tardó en manifestar su descontento con las demandas de los partidarios de la República social. De hecho, entre sus primeras decisiones se hallaba la orden de la eliminar a Blanc y a Albert de la Comisión Ejecutiva; el rechazo a la propuesta de un Ministerio Especial del Trabajo y

\footnotetext{
${ }^{128}$ Ibid.p.352.
}

${ }^{129}$ El 23 de abril de 1848, con la elección de la Asamblea, terminó la aventura igualitaria de los republicanos sociales. En su mayoría, el campesinado francés votó a favor de una Asamblea constituida por republicanos moderados y conservadores. Aunque la mayoría de ellos habían defendido el derecho al trabajo en su propaganda electoral (Donzelot,...,op.cit., p. 29) no estaban dispuestos a tomarse muy en serio esas promesas. Entre otras razones, la derrota se explica porque los conservadores capitalizaron muy bien el tema de la crisis y lo vincularon con la existencia de los Talleres Nacionales. Aunque la crisis que asolaba a los franceses no se debía ni exclusiva, ni principalmente, al costo de los Talleres Nacionales. Desde antes de febrero la circulación y la producción de mercancías se encontraban detenidas, el crédito privado agonizaba y el crédito público se había estancado. Además, la II República había heredado un enorme déficit de la Monarquía de Julio. Luis Felipe había hipotecado la nación en favor de una minoría de banqueros que aprovecharon la expansión económica para especular en connivencia con los promotores de negocios y los políticos asociados a ellos. Para salvar las finanzas el Gobierno Provisional aplicó el famoso recargo de los 45 centavos por franco. Los más afectados con esa medida fueron los campesinos, el impuesto agregó un motivo más para justificar su histórica desconfianza hacia los republicanos. Así, mientras que para los parisinos la II República simbolizaba democracia y derecho al trabajo, para los ellos comenzó a significar expolio e injusticia. Y esos centros sobrepoblados, con sus miles de obreros haciendo trabajos inútiles se les presentaron como el origen de una nueva desventura. Marx lo señalaba con toda claridad: "Los campesinos tenían que pagar los costos de la revolución de Febrero [...]El impuesto de los 45 céntimos era para el campesino francés una cuestión vital y la convirtió en cuestión vital para la república. Desde este momento, la república será el impuesto de los 45 céntimos y en el proletario de París vio al dilapidador que se daba buena vida a costa suya (Marx, Engels, Obras escogidas 1...op.cit. p.140). Aunque el margen de maniobra del Gobierno Provisional era estrecho, pero incluso en la situación en que se encontraba había salidas viables. Según afirma Marx en La lucha de clases en Francia una de ellas era la declaración de bancarrota, En esas circunstancias declararse en bancarrota no era la peor de las ideas, además de ayudar a deshacerse de una deuda a todas luces ilegitima legada, precisamente, por el régimen que el pueblo había derrocado, brindaría la autonomía económica necesaria para iniciar una verdadera reorganización social. Ocurrió, sin embargo, todo lo contrario: el Gobierno Provisional se opuso a la declaración de bancarrota por considerarla indigna y se apresuró a pagar a los acreedores del Estado en las fechas acordadas por la Monarquía de Julio. 
el inició una investigación sobre la situación del trabajo que presagiaba el fin de la Comisión de Luxemburgo y de los Talleres Nacionales. ${ }^{130}$

El 31 de mayo fueron publicadas las medidas adoptadas por la Asamblea respecto a la situación de Les Ateliers. En ellas se estipulaba que los trabajadores solteros de entre 18 y 25 años tendrían que inscribirse en el ejército; además, se añadía que los trabajadores que no podían justificar un período de seis meses de residencia en París debían ser expulsados. ${ }^{131} \mathrm{~A}$ principio de mayo la Comisión ejecutiva había decidido que el Estado compraría los caminos ferroviarios para que los trabajadores de los Talleres Nacionales se encargaran de su habilitación, sin embargo, en junio los Comités de Finanzas y del Trabajo, dirigidos ahora por los ex parlamentarios de la Monarquía de Julio, maniobraron para suspender el proyecto y hacer que la Comisión Ejecutiva pusiera en vigor las leyes publicadas el 31 de mayo. ${ }^{132} \mathrm{El}$ resultado era previsible: el 23 de junio París se había convertido, de nuevo, en un laberinto de barricadas.

Al grito de "du travail ou du plomb”, los obreros se enfrentaron a las fuerzas armadas. “La guerra más grande que han visto las calles” estaba en marcha. Al día siguiente París fue declarado estado de sitio, mientras todos los poderes ejecutivos le eran otorgados al General Cavaignac. La República, por la que habían luchado los trabajadores parisinos apenas unos meses atrás, se fortalecía con más vigor que nunca, pero no con reformas sociales destinadas

\footnotetext{
${ }^{130}$ La reacción popular no se hizo esperar. El 15 de mayo hubo una manifestación masiva encabezad por Huber, para pedir la intervención inmediata del gobierno francés en favor de los insurgentes polacos masacrados por los gobiernos de Prusia y Austria. La movilización fue convocada por los líderes de varios clubes parisinos enfatizando su carácter pacífico; sin embargo, el acto se salió de control y los manifestantes irrumpieron en la Asamblea Nacional. Ahí, Huber tomó la palabra intempestivamente para afirmar: "Yo, en nombre del pueblo, en el nombre del pueblo traicionado por sus representantes declaro disuelta la Asamblea Nacional” (Harsin, 2002: 290). Esas inesperadas palabras siguieron causando polémica un año después, cuando el propio Huber fue acusado de ser espía de la policía. La discusión respecto a la jornada del 15 de mayo todavía sigue generando controversia, H. Guillemin sostuvo la tesis de que la jornada fue una operación preparada con el fin de eliminar a los principales líderes revolucionarios. Esta perspectiva parece solidificarse con las evidencias que vinculan a Huber con el gobierno y con la inicial negativa de Blanqui y Barbès ante el plan de la movilización. Cabe recordar que diez años antes, en 1838, Huber entregó información secreta a la policía; sin embargo, Harsin cree que esto pudo ser un hecho aislado no vinculado con lo sucedido en 1848. No obstante, en ese momento la declaración provocó un caos inimaginable, al poco tiempo salió a la luz una lista con los nombres de un nuevo Gobierno Provisional: Barbès, Blanc, Ledru-Rollin, Blanqui, Huber, Raspail, Caussidière Étienne Arago, Albert, Lagrange, todos ellos partidarios de la República social. Ninguno de ellos llegó a ejercer sus funciones, sin embargo, apenas al anochecer la Guardia Nacional restableció el orden y los principales líderes fueron encarcelados. En tan sólo unas horas, lo que pintaba como una jornada revolucionaria culminó con el encarcelamiento de los líderes populares y con la Asamblea Constituyente más dispuesta que nunca a cortar de raíz aquello que percibían como la fuente de todo desorden: los Talleres Nacionales.

${ }^{131}$ Harsin,... op.cit.p. 293.

132 Vigier...op.cit. pp. 41-42.
} 
a profundizar la democracia, sino con una brutal represión hacia el pueblo francés. Las consecuencias de las jornadas de junio son bien conocidas: cientos de presos, 3,000 ejecutados, miles de familias deportadas a Argelia. Irónicamente, la estocada que puso fin al sueño igualitario de los republicanos sociales fue festejada en el Hôtel de Ville al grito de ¡Vive la Republique!. ${ }^{133}$

Así, mientras que en febrero de 1848 el sufragio universal y el derecho al trabajo pretendían "hermanar” a la sociedad, en junio éste último era concebido como la principal enfermedad de la República. ${ }^{134} \mathrm{Al}$ menos una cosa había cambiado desde entonces: el protagonista de esa obra llamada Revolución. Quienes ahora definían los ideales de la República no eran los trabajadores que vivieron en la miseria durante la Monarquía de Julio, ni los miles de desempleados que apenas sobrevivían en el París del siglo XIX, sino una Asamblea compuesta mayoritariamente por tres sectores: republicanos políticos vinculados a la burguesía francesa, ex legitimistas recién conversos al republicanismo y ex orleanistas en idéntica situación.

Precisamente ellos fueron quienes discutieron la situación del derecho al trabajo durante el otoño de 1848. Con los Talleres Nacionales clausurados, con el incipiente movimiento obrero reprimido y con los principales líderes socialistas presos, la Asamblea se negó a incorporar el derecho al trabajo a la constitución. Dos personajes de peso fueron los encargados de usar la tribuna para argumentar a favor de esta postura: Thiers y Tocqueville. No carece de importancia que fueran precisamente ellos quienes se opusieran al derecho al trabajo. Antes de febrero Thiers llegó a ser ministro del interior en el gobierno de Luis Felipe y hasta febrero de 1848 fue un convencido defensor de la figura del rey. Por su parte, Tocqueville había manifestado claramente su oposición a la Revolución de febrero, aunque defendía el sufragio universal masculino. A pesar de todas sus diferencias, ambos lograron encontrar un punto de coincidencia: su rechazo a la implementación del derecho al trabajo.

\footnotetext{
${ }^{133}$ Cfr., Harsin, ...op.cit. 293ss.. Esto explica por qué el socialismo posterior a 1848, incluido el propio Marx, vieran con recelo los ideales republicanos así resignificados. Sin embargo, el espíritu del republicanismo radical francés, ese que aparece en Robespierre bajo la premisa de instaurar una democracia política y, sobre todo, económica, no será abandonado nunca por Marx.

${ }^{134}$ Cuando se dio la noticia de que las barricadas habían sido derrotadas el parlamento festejó con un sonoro: !Vive la Republiquei (Harsin,...op.cit,p.300).
} 
Paradoja de paradojas, apenas en febrero, el derecho al trabajo le otorgaba legitimidad a la Revolución entre las clases populares, sin embargo, menos de un año después, ${ }^{135}$ ese mismo derecho habría de convertirse en el caballo negro de la II República. Como señala Jacques Donzelot, para el otoño de 1848 las manifestaciones populares en defensa del derecho al trabajo fueron interpretadas por los nuevos partidarios de la República como:

[...] una intolerable manifestación de comportamiento antidemocrático, un crimen de lesa majestad contra el pueblo cometido por las fracciones más turbulentas y menos cívica de ese mismo pueblo. ${ }^{136}$

En el fondo, de lo que se trataba era de mantener a toda costa el mundo del trabajo fuera de cualquier regulación social. Años después Marx recordaría que la Asamblea Nacional aplaudió “con gritos atronadores” las palabras del nuevo ministro del trabajo, Ulysse Trélat, según las cuales el nuevo gobierno republicano sólo debía: "reducir el trabajo a sus antiguas condiciones”. ${ }^{137}$

Pero, ¿cuáles eran esas condiciones? Como prefecto de la policía en el periodo de la Monarquía de julio Girod de l'Ain -un autoproclamado liberal- se opuso frontalmente a las peticiones de los obreros para que el derecho mediara en las relaciones laborales con el siguiente argumento:

Toda demanda que se nos dirija pidiéndonos que intervengamos entre patrono y obrero sobre la fijación de los salarios, o la duración de la jornada de trabajo, o la elección de obreros, no puede admitirse, puesto que está en oposición a las leyes que han consagrado el principio de la libertad de industria $(\mathrm{c} / \mathrm{n}){ }^{138}$

De manera que "regresar el trabajo a sus antiguas condiciones", significaba mantener el principio de no intervención en los asuntos laborales defendido por los sectores liberales de la Monarquía orleanista. Así, a pesar de sus viejas diferencias, ex-monárquicos y

\footnotetext{
${ }^{135}$ Véase si no el contenido del decreto con el que se anunciaba la puesta en marcha de la Comisión de Luxemburgo: "Considerando que la Revolución, hecha por el pueblo, debe hacerse para él: Que es tiempo de poner fin a los largos e inicuos sufrimientos de los trabajadores. Que la cuestión del trabajo es de importancia suprema. Que no hay preocupaciones más elevadas y más dignas de un gobierno republicano (c/n) [...] El gobierno provisional de la República decreta: se designará una comisión permanente, que se llamará omisión del gobierno para los trabajadores, con la misión específica y expresa de considerar su destino" Citado en: Sewell..., op.cit., p.340.

${ }^{136}$ Donzelot...op.cit.p.39.

${ }^{137}$ Marx, Engels, 1977:45.

${ }^{138}$ Citado en: Sewell,...op.cit.p.272.
} 
republicanos moderados se unieron en torno a la II República para salvaguardar la libertad de industria, la libertad de competencia ilimitada y la libertad de trabajo, todas ellas, libertades "modernas" que debían mantener la independencia de la esfera civil respecto a las decisiones del ámbito político.

Las barricadas de junio terminaron de confirmar la distancia existente entre el proyecto liberal y el asociacionismo republicano. Desde entonces, el movimiento obrero francés dejó de lado la retórica fraternal para fortalecer el discurso que denunciaba la confrontación insuperable entre los intereses de la clase propietaria y las demandas de la clase trabajadora. ${ }^{139}$ Los acontecimientos históricos de ese momento no parecían negarles la razón. Así, Karl Marx, quien en 1847 fuera ex-vicepresidente de la Asociación para la Cofraternización de los trabajadores de Europa, escribía con desprecio en 1850:

La fórmula que se correspondía con esta fantaseada superación de las relaciones entre las clases era la fraternité, la cofraternización y la fraternidad universales. Esa cómoda abstracción de los conflictos de clase. ${ }^{140}$

Este cambio de postura no tenía nada de enigmático: para los sectores más radicales la defensa de la República sólo tenía sentido si se hacía uso del derecho para interferir con los resortes de todas las formas de dependencia, incluidas, desde luego, las formas de dependencia inauguradas por el "imperio de la competencia ilimitada”. ${ }^{141}$ De otra manera, la República terminaba por convertirse en un instrumento de las clases propietarias para mantener su posición de privilegio. No obstante, el fracaso del proyecto democrático fraternal no expresaba tanto la falsedad de los ideales de igualdad y libertad, como la imposibilidad de llevarlos a cabo cuando amplios sectores de la sociedad vivían en una situación de dependencia estrechamente vinculada a la existencia de un conjunto peculiar de privilegios que, sin embargo, habían sido declarados intocables para las instituciones del derecho republicano.

\footnotetext{
139 No sólo Marx había llegado a esta conclusión. En sus memorias, Alexis de Tocqueville recordaba los acontecimientos de ese año de la siguiente manera: "Vi la sociedad partida en dos: los que nada poseían, unidos en una común codicia (i!); quienes poseían algo, en una angustia común. Se acabaron los lazos, se acabaron las simpatías entre las dos clases: imperaba por doquier la lucha inevitable e inmediata”. (Citado en: Doménech...op.cit. p.115).

140 Marx, Karl, Obras escogidas 1...op.cit.

${ }^{141}$ En un texto titulado precisamente "Unité, égalité, fraternité” con fecha del 2 de febrero de 1834, Blanqui afrmaba: "Si en effet nous nous disons républicains, c’est que nous espérons de la république une réforme sociale que la France réclame impérieusement” Blanqui...op.cit.p.261.
} 
Ni la distinción habilitada por Constant entre la libertad de los antiguos y la libertad de los modernos, ni la que más tarde elaboraría Isaiah Berlin entre libertad positiva y libertad negativa, ${ }^{142}$ permiten comprender lo que estaba en juego en las disputas políticas de la Francia decimonónica. Si la libertad individual proclamada por los liberales fue impugnada por distintos sectores de la sociedad apelando a una organización colectiva, si incluso hubo autores que idealizaron la vida comunitaria frente a la vida burguesa, fue sólo porque, en nombre de esa libertad, la industrialización capitalista no dejó de provocar efectos nocivos sobre toda una clase social.

Las disputas políticas del siglo XIX se entienden muy mal si, por un lado, se presenta a los defensores de la libertad individual y la propiedad privada, mientras que, por el otro, se coloca a los amantes de lo colectivo y lo comunitario. En realidad, a mediados del siglo XIX comenzaban a fraguarse dos estrategias políticas distintas que, apropiándose de la herencia ilustrada, se oponían al Antiguo Régimen de formas diferentes. Conforme se agudizaban los procesos de industrialización y la producción capitalista adquiría fuerza en Inglaterra y Francia, la question social demostraba ser aquello que distinguía ambas estrategias. A pesar de estar envueltas en un lenguaje confuso, las primeras asociaciones de trabajadores ${ }^{143}$ no partían de una concepción política frontalmente opuesta a la idea de libertad individual; en todo caso, su defensa de lo colectivo era un recurso práctico para enfrentar los estragos del nuevo sistema laboral. Cuando, gracias a la retórica republicana, el movimiento obrero logró dibujar un programa político más o menos coherente, no defendió las virtudes naturales de la colectividad frente a los vicios del individualismo, sino la necesidad de transformar las condiciones imperantes en la esfera del trabajo ante la inocultable evidencia de que era en ella donde se le negaba la libertad (antigua y moderna) a toda una clase social. Con sus propias particularidades, en Inglaterra ocurría un fenómeno semejante: el movimiento cartista había obtenido importantes victorias defendiendo una Carta que exigía la ampliación

\footnotetext{
142 En la primera de las cuales Berlin ubicaba autores como Hegel y Marx, pero también a los jacobinos en la medida en la cual, desde su perspectiva, estos intentaban imponer una forma de vida emancipada a los otros seres humanos en función de una verdad a la que supuestamente habían accedido. Cfr, Lessnof, Michael, La filosofía política del siglo XX, Akal, Madrid, 2011, pp. 232ss.

${ }^{143}$ Harvey, David, París...op.cit. p. 99ss.
} 
de derechos políticos y civiles como parte de su lucha contra los estragos de la industrialización capitalista. ${ }^{144}$ De ahí que la derrota de 1848 no sólo representara un duro golpe para el incipiente movimiento obrero europeo, ${ }^{145}$ sino que, al menos temporalmente, dinamitó la esperanza de transformar la question social mediante instrumentos jurídicos.

Fue en este escenario que el proyecto liberal se erigió como la principal alternativa política para encabezar la entrada en la modernidad. En efecto, una vez que el republicanismo fraternal se disolvió, el liberalismo pudo presentarse como la única alternativa de organización social, jurídica y política que se oponía a los vestigios del Antiguo Régimen. Sin embargo, para que esto fuera posible se requería que, en el horizonte del saber de esa época, comenzara a articularse un discurso más o menos coherente por el cual las apuestas políticas de quienes se oponían al derecho al trabajo pudieran ser presentadas como una alternativa racional.

\footnotetext{
144 Tate, Morton,...op.cit.p. 107ss.

${ }^{145}$ El movimiento obrero recibió un duro golpe en 1848, sin embargo éste no sólo tuvo repercusiones en Francia e Italia, sino también en Inglaterra, como señala Saskia Sassen "Si bien las revueltas sociales que afectaron a Europa continental no se sintieron con la misma intensidad en Inglaterra, los patrones las utilizaron como excusa para reprimir a los trabajadores eliminando al a interrupción para las comidas, reincorporando los turnos de trabajo nocturno para los hombres, y despidiendo a las mujeres y los niños” (Sassen, Saskia, Territorio, autoridad y derechos: de los ensamblajes medievales a los ensamblajes globales, Katz, Madrid, 2010,p.161).
} 


\section{Capítulo 2}

\section{EI trabajo en el dispositivo liberal}

El análisis histórico de los acontecimientos de 1848 nos ha obligado a tomar distancia de un conjunto de idealizaciones normativas habituales en la filosofía política contemporánea. Ciertamente, tanto la defensa de la libertad individual, como la reivindicación de la propiedad jugaron un papel primordial en el discurso liberal del siglo XIX, sin embargo, frecuentemente se olvida que dichos elementos funcionaban en el interior de un dispositivo mucho más complejo. El año de 1848 es particularmente revelador al respecto, la sucesión de hechos de ese turbulento periodo evidencia cómo, antes que salvaguardar la esencia de la libertad individual y la propiedad, el proyecto liberar hacia funcionar esas reivindicaciones en una estrategia discursiva más amplia destinada a legitimar el nuevo orden laboral.

Faltaríamos a la verdad si negáramos que la adopción del discurso liberal en las esferas políticas de Europa obedeció a las exigencias internas de la industrialización capitalista. A pesar de ser cierta, semejante explicación sólo puede ser planteada de forma retrospectiva. En el momento de su consolidación, los artífices del discurso liberal no se pensaban a sí mismos construyendo los cimientos de la "superestructura ideológica del capitalismo”, más bien, se esforzaban por legitimar sus peculiares elecciones políticas y económicas ${ }^{146}$ a través de un discurso coherente al que le atribuían un carácter verdadero. En adelante, trataremos de mostrar que ese discurso no se articulaba en torno a la defensa de la libertad y la propiedad, sino integrando esos conceptos en un dispositivo de saber-poder bastante peculiar. ${ }^{147}$ Un dispositivo cuya coherencia interna dependía enteramente del papel que debía asignársele al trabajo en las sociedades modernas.

\footnotetext{
${ }^{146}$ Sin duda, entre los autores liberales del siglo XIX existían profundas diferencias, sin embargo, la mayoría de ellos coinciden en defender la libertad de comercio, la libertad de trabajo y la adopción del patrón oro, en materia económica (Polanyi, Karl, La gran transformación, 2009:192 s.), al mismo tiempo que reivindican el derecho de propiedad, la garantía de los derechos civiles y la defensa de una forma ampliada de sufragio censitario -nunca un régimen democrático-, en el ámbito político.

${ }^{147}$ Como hemos señalado en un comienzo, Michel Foucault llamó gubernamentalidad al tipo de racionalidad específica que subyace a ciertas estrategias de gobierno sobre los sujetos; en tanto forma de racionalidad, la gubernamentalidad vincula discursos y prácticas en un mecanismo coherente destinado a dirigir la conducta de los hombres hacia una finalidad concreta.
} 


\subsection{El liberalismo, una realidad del siglo XIX}

\section{La propiedad en Locke, ¿antecedente del liberalismo?}

Buena parte de los análisis contemporáneos suelen remontarse a la obra de John Locke al momento de localizar el origen del liberalismo político. ${ }^{148}$ Según una interpretación ampliamente extendida, los trabajos del inglés contendrían el germen de las reflexiones que el liberalismo político moderno vendría a desarrollar durante los siglos posteriores. De esta forma, entre la obra de Locke y el trabajo de pensadores como Benjamin Constant, Alexis de Tocqueville e incluso Robert Nozcik, habría una línea de continuidad bien definida, un hilo conductor claramente identificable a partir de temas como la oposición a la intervención estatal, la reivindicación de la libertad individual y la defensa de la propiedad privada.

Sin embargo, una mirada atenta a la singularidad de las experiencias históricas nos ofrece una perspectiva distinta. En realidad, las reflexiones de Locke en el siglo XVII no abordaban los mismos problemas ${ }^{149}$ que el pensamiento liberal trataría más de un siglo después. ${ }^{150}$ Allí donde éste último analizará la libre apropiación del trabajo asalariado sobre

${ }^{148}$ Así, por ejemplo, en un libro por demás interesante, Jacques Bidet sostiene que: “Toute la première partie de l'ouvrage -se refiere al Segundo Tratado...- est en effet consacrée à la mise en place d'un ordre naturel celui de la famille, de la propiété privée et capitaliste [...]. Le contrat social voit dès lors son objet très strictement délimité : il sera l'association pour la défense de cet ordre natural, des lois incontestables de la propiétée. La contradiction du libéralisme éclate ici dans toute son ampleur [...]. On aboutit à ce paradoxe : Locke, qui « inventé» la démocratie moderne, en attribue aux propiétaires le strict monopole” (Bidet, Jacques, Théorie de la Modernité, PUF, Paris, 1990,p.25). Aunque en sentido inverso, esta interpretación no se aleja de la perspectiva de un anarco liberal como Robert Nozcik. quien, en Anarquía, Estado y utopía, Nozcik intenta mostrar la continuidad de su teoría liberal en el contexto de una sociedad de mercado democrática con la concepción lockeana del derecho natural. (Cfr., Nozcik, Robert, Anarquía, Estado y utopía, FCE, México 1991).

${ }^{149}$ Aquí seguimos la perspectiva analítica que caracteriza los procedimientos arqueológico y genealógico de Michel Foucault. Como heredero de la perspectiva epistemológica de Georges Canguilhem, Foucault sabía muy bien que para relacionar dos elementos en un mismo marco de análisis no basta con observar semejanzas terminológicas, sino que es necesario corroborar que responden a los mismos problemas teóricos o, en palabras de Foucault, al mismo régimen de verdad. Al respecto véase el Anexo localizado al final de este trabajo.

${ }^{150}$ En este punto, McPherson acierta al señalar que buena parte de las interpretaciones de Locke son incapaces de comprender el sentido de su teoría debido a que parten de consideraciones anacrónicas. Al localizar en el autor inglés al fundador de la democracia liberal, los interpretes del siglo XX soslayan la relación de la obra de Locke con su propio tiempo. Ante lo cual, McPherson señala que es posible solventar las contradicciones que se derivan de esta lectura mediante una interpretación que tome en consideración el contexto de la obra de Locke (Cfr., Macpherson, C.B., La théorie politique de l'individualisme possessif. De Hobbes à Locke. Gallimard, Paris, 2004, pp. 322-326). No obstante, a nuestro modo de ver, el autor canadiense ofrece una explicación poco satisfactoria. Para él, estas contradicciones se deben al hecho de que Locke coloca los presupuestos de su tiempo en la naturaleza humana, así, la idea de un sujeto como individuo propietario capaz de realizar contratos terminaría siendo traspolada al estado de naturaleza para explicar las cualidades ahistóricas del hombre y construir una teoría política consecuente. Según esta lectura, el capítulo de la propiedad 
la base de un proyecto económico de libre mercado; Locke pensaba las condiciones que legitimaban el poder de los Estados Nación europeos en el contexto de un expansionismo mercantil y colonial. ${ }^{151}$

De hecho, el concepto de propiedad que el liberalismo vendría a reivindicar en el siglo XIX difiere ampliamente del defendido por Locke a finales del siglo XVII. En realidad, el famoso capítulo cinco del Segundo Tratado sobre el Gobierno Civil no pretendía justificar la propiedad privada ilimitada como un derecho exclusivo y excluyente frente a los abusos de un Estado omnipotente. ${ }^{152}$ Ciertamente su objetivo consistía en analizar las condiciones que permitían la apropiación de la tierra antes de la instauración de cualquier orden político con el fin de establecer las bases de la propiedad en los gobiernos civiles, pero también tenía la función de legitimar la ocupación territorial de los ingleses en América del norte. Esta doble vertiente explica algunas ambigüedades aparentes que la interpretación liberal tiende a pasar por alto. Veamos.

Como es de sobra conocido, en el Segundo Tratado... Locke continuaba la disputa teórica con Robert Filmer emprendida unos años atrás. Frente a las hipótesis defendidas en El Patriarca, el autor de la Carta sobre la tolerancia sostenía que la tierra había sido otorgada por Dios a todos los hombres en común. De lo cual, deducía que el único medio que justificaba su apropiación era el trabajo individual y no un presunto derecho de linaje. ${ }^{153} \mathrm{Sin}$ embargo, inmediatamente después, el autor agregaba que la misma ley natural que legitimaba la apropiación de la tierra mediante el trabajo individual establecía dos límites a dicha

tendría el objetivo de naturalizar una concepción de la propiedad ínsita al mundo capitalista en oposición a la experiencia del derecho natural precedente que imponía límites a la apropiación. (Cfr.,Ibid,p.326ss.)

${ }^{151}$ Tal como afirma James Tully en la teoría de Locke no existen las condiciones teóricas que servirían para legitimar la apropiación del trabajo asalariado. Dichas condiciones sólo fueron forjadas por los pensadores liberales de los siglos XVIII y XIX; sin embargo, Locke sí respondía a las exigencias de una Europa organizada en torno a las exigencias de un capitalismo comercial en plena expansión colonial. Por lo mismo, el inglés estaba interesado en justificar la apropiación de la propiedad en las colonias de América del norte. Cfr. Renault, Mathieu, L'Amérique de John Locke. L'Expansion Coloniale de La Philosophie Européenne, Paris, Éditions Amsterdam, 2014.

152 Para un análisis detallado de esta posición, remitimos al imprescindible libro de James Tully, A discourse on property. John Locke and his adversaries, donde el autor muestra de forma convincente que el tema de la propiedad es analizado por Locke desde unas coordenadas teóricas absolutamente distintas a las que ordenaron la cartografía política del liberalismo decimonónico.

${ }^{153}$ Así lo aclaraba Locke explícitamente: “[..]without supposing any private dominion, and property in Adam, over all the world, exclusive of all other men, which can no way be proved, nor any one's property be made out from it; but supposing the world given, as it was, to the children of men in common, we see how labour could make men distinct titles to several parcels of it, for their private uses; wherein there could be no doubt of right, no room for quarrel”. (Locke, John, Second Treatise of Government, Hackett Publishing Company, United States of America, 1980p.18). 
apropiación, a saber: la capacidad para hacer uso de los bienes producidos y el bienestar de los demás seres humanos:

The measure of property nature has well set by the extent of men's labour and the conveniencies of life [...] This measure did confine every man's possession to a very moderate proportion, and such as he might appropriate to himself, without injury to any body. ${ }^{154}$

De entrada, parecía quedar claro que la ley de naturaleza no pretendía legitimar una modalidad de apropiación ilimitada y excluyente, sino, por el contario, limitada e incluyente. No obstante, en los parágrafos posteriores Locke realizaba un desconcertante movimiento teórico: manteniendo su reflexión en el marco del estado de naturaleza, señalaba dos circunstancias que podían modificar esa "regla de la propiedad” previamente establecida por la ley natural:

[...] this I dare boldly affirm, that the same rule of propriety, that every man should have as much as he could make use of, would hold still in the world, without straitening any body; since there is land enough in the world to suffice double the inhabitants, had not the invention of money, and the tacit agreement of men to put a value on it, introduced (by consent) ${ }^{155}$ larger possessions, and a right to them. ${ }^{156}$

A diferencia de lo que afirma McPherson en La teoría política del individualismo posesivo, esta indicación no tenía la intención de justificar las diferencias de propiedad en el orden político ulterior. En realidad, en este punto, el inglés seguía el procedimiento clásico del contractualismo político, esto es: iniciaba exponiendo las dificultades inherentes al estado de naturaleza para mostrar que éstas sólo podían ser combatidas mediante la instauración de un acuerdo político. Así, al final de este capítulo, Locke señalaba explícitamente que las desigualdades generadas antes del gobierno civil por el uso de la moneda y por la atribución de un valor a la tierra, debían ser superadas a través de la instauración de un acuerdo político capaz de regular la propiedad jurídicamente:

This partage of things in an inequality of private possessions, men have made practicable out of the bounds of society (c/n), and without compact, only by putting a value on gold and silver,

\footnotetext{
${ }^{154}$ Ibid.p.22

155 Este paréntesis es omitido de la traducción al español.

156 Ibid.p.23.
} 
and tacitly agreeing in the use of money: for in governments, the laws regulate the right of property, and the possession of land is determined by positive constitutions $(\mathrm{c} / \mathrm{n}){ }^{157}$

Como veremos, la regulación política de la propiedad defendida por Locke será distinta a la concepción del liberalismo posterior. Sin embargo, antes debemos detenernos en un punto de suma importancia. Al distinguir entre un momento dominado por la "regla de propiedad” y otro determinado por la aparición del dinero y la asignación de un valor a la tierra, el inglés parecía hacer uso de una noción poco consistente del estado de naturaleza. Lejos de ser el producto de una suerte de ligereza conceptual, esta distinción refleja que Locke no imaginaba ese orden pre-político como una simple “hipótesis contra-fáctica” o como un mero ejercicio intelectual. Al contrario, en la argumentación del inglés el estado de naturaleza era concebido como una realidad atravesada por su propia temporalidad y, también, por su propia geografía.

En efecto, a partir del parágrafo 45 del Segundo Tratado... Locke realiza una especie de cronología del estado de naturaleza. En ella, analiza las diferentes etapas por las cuales han pasado los hombres en su relación con la propiedad antes de la consolidación de un gobierno civil: empezando por la apropiación de la tierra comunal mediante el trabajo individual, hasta llegar a la creación del dinero y los intercambios comerciales. ${ }^{158}$ Sin embargo, esta cronología no tenía un mero valor conjetural. A lo largo de toda la obra Locke insistirá en que la existencia de América ofrece un testimonio empírico que puede servir para estudiar el desarrollo del estado de naturaleza. ${ }^{159}$ Como en su momento lo hicieron Thomas Moro y Francis Bacon, el autor de la Carta sobre la tolerancia creía poder ver en este “nuevo mundo” recién “descubierto” el pasado de Europa. Este pasado, además, tenía la ventaja de

\footnotetext{
157 Ibid.p..29- 30.
}

158 Aunque Locke señala que los intercambios monetarios requerían una organización social y un conjunto de pactos, no por ello estaban inscritos en un gobierno civil. Como él mismo afirmaba en el capítulo dos sobre el estado de naturaleza: "I have named all governors of independent communities, whether they are, or are not, in league with others: for it is not every compact that puts an end to the state of nature between men, but only this one of agreeing together mutually to enter into one community, and make one body politic; other promises, and compacts, men may make one with another, and yet still be in the state of nature”(Ibid.).

${ }^{159}$ Unas páginas atrás, en el capítulo dedicado al estado de naturaleza, Locke había contestaba con toda claridad a aquellos que se preguntaban “dónde” podían encontrarse hombres como los descritos por él: "It is often asked as a mighty objection, where are, or ever were there any men in such a state of nature? [...] The promises and bargains for truck, between the two men in the desert island, mentioned by Garcilasso de la Vega, in his history of Peru; or between a Swiss and an Indian, in the woods of America, are binding to them, though they are perfectly in a state of nature, in reference to one another: for truth and keeping of faith belongs to men, as men, and not as members of society”. (Ibid.) 
ofrecer una especie de constatación empírica de las circunstancias que se habían vivido en el “Viejo mundo” antes de la consolidación de los gobiernos civiles:

Thus in the beginning all the world was America, even more so than America is now, because in the beginning no such thing as money was known anywhere. Find out something that has the use and value of money among a man's neighbours and you'll see him start to enlarge his possessions. ${ }^{160}$

El desarrollo aparentemente errático del capítulo cinco adquiere pleno sentido a la luz de esta consideración. ${ }^{161}$ Aunque en el Segundo Tratado..., Locke afirmaba que la ley de naturaleza garantizaba la apropiación de la tierra mediante el trabajo individual, resulta apresurado deducir que el autor pretendía legitimar con ello una concepción del derecho de propiedad fundada en la ausencia de toda regulación del Estado. Tampoco parece del todo convincente aquella interpretación que encuentra en la obra de Locke las bases teóricas para justificar una sociedad que legitime la limitación de los beneficios de la producción a unos pocos propietarios privados. ${ }^{162}$ En realidad, el inglés afirmaba justo lo contrario. Desde su perspectiva, gracias a que la propiedad de la tierra se fundaba en el trabajo de los individuos, los recursos aumentaban permitiendo que el conjunto entero del género humano pudiera tener acceso a ellos:

[...] that he who appropriates land to himself by his labour, does not lessen, but increase the common stock of mankind: for the provisions serving to the support of human life, produced by one acre of inclosed and cultivated land, are (to speak much within compass) ten times more than those which are yielded by an acre of land of an equal richness lying waste in common. And therefore he that incloses land, and has a greater plenty of the conveniencies of life from ten acres, than he could have from an hundred left to nature, may truly be said to give ninety acres to mankind: for his labour now supplies him with provisions out of ten acres, which were but the product of an hundred lying in common. ${ }^{163}$

160 Ibid.p.29. En la traducción al español el sentido original de la frase se vuelve imperceptible. Donde Locke afirma: "Thus in the beginning all the world was America(c/n)", la versión de Alianza traduce: "Esta fue, en un principio, la situación en América(c/n)”. En la traducción al francés, en cambio, el sentido parece acentuarse: “Ainsi, au commencement, tout le terre était comme une Amérique (c/n)» (Citado en: Renault, Mathieu...op.cit.p.63.

${ }^{161}$ De hecho, sólo tomando en cuenta las continuas referencias a América en el libro cinco, la argumentación de inglés adquiere cierta coherencia. De otra manera no se entendería porqué lo que en un principio parece ser un elogio del crecimiento ilimitado de la propiedad termina derivando en una posición altamente favorable a la regulación del Estado en esa materia.

162 Más cerca de esta perspectiva se encontraba Filmer, quien, mediante la apelación al derecho divino intentaba justificar el carácter naturalmente privado de la propiedad.

${ }^{163}$ Locke,...op.cit.p.23. 
Así, en última instancia, si la apropiación de la tierra mediante el trabajo era legítima se debía a que el esfuerzo de los hombres sobre ella terminaba redundando en el bienestar de todo el género humano. Si, por el contrario, la apropiación de la tierra impedía la satisfacción de las necesidades de los otros ésta debía ser considerada como ilegitima de acuerdo a lo estipulado por las leyes de naturaleza. Una vez afirmado lo anterior, Locke lanzaba una pregunta que, a primera vista, no tenía relación con la argumentación precedente:

[...] for I ask, whether in the wild woods and uncultivated waste of America, left to nature, without any improvement, tillage or husbandry, a thousand acres yield the needy and wretched inhabitants as many conveniencies of life, as ten acres of equally fertile land do in Devonshire, where they are well cultivated? ${ }^{164}$

¿Por qué, repentinamente, las tierras no cultivadas de América cobraban interés en un texto supuestamente dedicado a establecer los fundamentos filosóficos de la propiedad? Si, como mostraba Locke, en última instancia, la legitimidad de la propiedad a través del trabajo descansaba en que éste ayudaba a la satisfacción de las necesidades de todos los hombres, la posesión de tierras no cultivadas incumplía el fundamento mismo de las leyes naturales. Los indígenas de América podían reivindicar la propiedad de sus tierras argumentando que de facto ellos eran sus primeros poseedores, pero de iure esta reivindicación resultaba ilegítima pues contradecía el fundamento mismo del derecho de propiedad.

Ahora bien, Locke había iniciado el capítulo cinco afirmando que, en ausencia de gobierno, la apropiación de las tierras comunales no requería del consentimiento de todos los hombres: siempre que la tierra fuera lo suficientemente abundante para que el acceso de unos no afectara al resto de los hombres, su apropiación no requería el consentimiento de todos los habitantes. ${ }^{165}$ De esta forma, al volver fértiles tierras hasta antes ociosas en beneficio de la humanidad, la apropiación sin consentimiento resultaba legítima conforme a las leyes naturales.

Esta afirmación coincidía plenamente con la idea que, Locke en particular y los pensadores ingleses en general, se hacía de América del norte. Para ellos, las colonias eran

\footnotetext{
164 Ibid.p.24.

165 Ibid.p.19.
} 
pensadas como vastos espacios de tierra fértil no cultivada: la misión de los colonos no era otra sino la de poner a trabajar esos terrenos en beneficio del género humano. De esta manera, su empresa no requería el consentimiento de los pobladores indígenas, era legitima en razón de unas leyes naturales inspiradas en la voluntad del Creador.

Sin embargo, Locke se oponía a los argumentos de los autores españoles que legitimaban la conquista violenta de los pueblos de América por motivos religiosas. Así, en sus Cartas sobre la tolerancia, el inglés mostraba que las disputas en materia religiosa no podían servir como un argumento de orden político. Esta posición crítica respecto a la conquista de América parecía contradecir el apoyo explícito de Locke a la empresa colonial inglesa. Como es bien conocido, el inglés fue uno de los redactores de las Constituciones de Virginia y de Carolina y estaba vinculado a varias empresas esclavistas. En realidad, desde el punto de vista de su teoría no había ninguna contradicción. Si la intervención de los españoles en América era ilegitima se debía a que sus motivaciones eran de corte religioso, en cambio, la apropiación de las tierras de América del norte por parte del imperio inglés estaba sustentada en la única legislación que podía ser válida en aquellos territorios donde aún no se instauraba un gobierno civil: las leyes naturales.

Así, el capítulo cinco del Segundo Ensayo... no pretendía hacer pasar como natural una modalidad de propiedad que luego se hallará en las sociedades políticas, sino que elaboraba una legitimación filosófica de la apropiación de las tierras infértiles en lugares que eran imaginados como la expresión del estado de naturaleza. Por ello, cuando, en el capítulo siete, Locke cambia de registro para analizar las condiciones que le otorgan legitimidad a una sociedad política o civil, no sólo desplaza el nivel de análisis de su reflexión sino también la zona geográfica a la que ésta se refiere. Mientras que el “derecho natural” rige en ese Viejo Mundo en el que los gobiernos civiles ya han sido edificados, en el "Nuevo Mundo" las “leyes naturales” son las que regulan el orden pre-político.

Ahora bien, los argumentos de Locke sobre la instauración de un gobierno civil son de sobra conocidos: para el inglés la libertad, la vida y la propiedad de todos y cada uno de los miembros de la sociedad se encuentran en riesgo en el orden pre-político, ${ }^{166}$ por lo cual se vuelve necesaria la instauración de un gobierno civil a fin de salvaguardar las leyes naturales prescritas por Dios. Locke hace descansar la legitimidad de dicho gobierno en un

${ }^{166}$ Incluso si la ley de naturaleza prescribe su obligatoriedad (Locke, John, Segundo...op.cit.p. 134)-. 
acuerdo político ${ }^{167}$ en el que los individuos se comprometen a ceder su capacidad de hacer justicia por su propia mano a cambio de que el legislador lo haga en función del beneficio colectivo. ${ }^{168}$ No obstante, el inglés también afirma que, en aras de garantizar la propiedad de todos los miembros del orden político, el legislador debe encargarse de reglamentar la tierra mediante una constitución orientada a preservar el bienestar público. Así, cuando los individuos acceden a formar parte de un Estado, se ven obligados a supeditar sus propiedades al interés colectivo: ${ }^{169}$

[...]that every man, when he at first incorporates himself into any commonwealth, he, by his uniting himself thereunto, annexed also, and submits to the community, those possessions, which he has, or shall acquire, that do not already belong to any other government: for it would be a direct contradiction, for any one to enter into society with others for the securing and regulating of property; and yet to suppose his land, whose property is to be regulated by the laws of the society, should be exempt from the jurisdiction pf that government, to which he himself, the proprietor of the land, is a subject. By the same act therefore, whereby any one unites his persons, which was before free, to any common-wealth, by the same he unites his possessions, which were before free, to it also; and they become, both of them, person and possession, subject to the government and dominion of that common-wealth, as long as it hath a being. Whoever therefore, from thenceforth, by inheritance, purchase, permission, or otherways, enjoys any part of the land, so annexed to, and under the government of that common-wealth must take it with the condition it is under; that is, of submitting to the government of the common-wealth, under whose jurisdiction it is, as far forth as any subject of it. ${ }^{170}$

Dado que la instauración de la sociedad política tenía por objetivo garantizar las leyes de naturaleza, la intervención del gobierno civil es legitima en aquellos casos en los que los derechos de propiedad, libertad y vida se encuentren en riesgo. Cuando la apropiación de

\footnotetext{
${ }^{167}$ Dice Locke: "Al ser los hombres, como ya se ha dicho, todos libres por naturaleza, iguales e independientes, ninguno puede ser sacado de esa posición y puesto bajo el poder político de otro sin su propio consentimiento. El único modo en el que alguien se priva a sí mismo de su libertad natural y se somete a las ataduras de la sociedad civil es mediante un acuerdo con otros hombres, según el cual todos se unen formando una comunidad, a fin de convivir los unos con los otros de una manera confortable, segura y pacífica, disfrutando sin riesgo de sus propiedades respectivas y mejor protegidos frente a quienes no forman parte de esa comunidad [...]. Así, cuando un grupo de hombres ha consentido formar una comunidad o gobierno, puedan con ello incorporados $s$ un cuerpo político en el que la mayoría tiene el derecho de actuar y decidir en nombre de todos” (Locke, 2004: 111).

${ }^{168}$ Cfr. Locke,...op.cit.p.134ss

${ }^{169}$ Sólo desde las coordenadas del liberalismo del siglo XIX un argumento así puede sorprendernos. Para Locke es claro que el derecho a la propiedad sólo puede ser garantizado para todos los miembros de un orden político si el Estado interviene en la distribución social de la tierra, sólo desde el liberalismo del siglo XIX comienza a tener sentido la idea de que el derecho a la propiedad puede ser garantizado mediante la no intervención del Estado.

${ }^{170}$ Ibid.p.64.
} 
unos cuantos es capaz de impedir el acceso de los demás a la propiedad, el orden político debe intervenir a través del instrumento legislativo. En ese sentido, el gobierno, constituido mediante un acuerdo común, tenía, al mismo tiempo, la obligación de garantizar la propiedad privada y la atribución de intervenir para lograrlo de ser necesario. No existía en ello ninguna contradicción. En las coordenadas teóricas de Locke, la división entre lo público y lo privado aún no era pensable en los términos del liberalismo posterior. ${ }^{171}$ De ahí que la defensa de la propiedad privada fuera perfectamente compatible con la regulación social del Estado.

En realidad, Locke nunca argumentó en contra de un Estado intervencionista, sino en oposición de la ilegitimidad de poderes arbitrarios sin ningún control por parte de los miembros del cuerpo político. La distinción entre el estado de naturaleza y el gobierno civil no tenía como objetivo distinguir entre la esfera de lo privado y la esfera de lo púbico, con el fin de salvaguardar la primera en contra de los ataques de la segundad: por el contrario, evidenciaba la imposibilidad de garantizar la libertad, la propiedad y la vida en ausencia de un poder político socialmente constituido. Sin embargo, al señalar que el objetivo natural de la propiedad era satisfacer las necesidades de los seres humanos mediante el trabajo, Locke no hacía otra cosa sino justificar la intervención de un gobierno civil como el inglés en un territorio aún en estado de naturaleza como América para trabajar sus extensas tierras no cultivadas en apego a la ley de naturaleza. Así, más que distinguir entre la esfera de lo público y la esfera de lo privado, Locke distinguir entre una sociedad civil europea, donde la insuficiencia de propiedad ${ }^{172}$ obligaba a imponerle fuertes restricciones jurídicas y políticas, y unas sociedades aún en estado de naturaleza cuya abundancia de tierras ociosas legitimaba la intervención “pacífica” e “industriosa” de las colonias inglesas.

${ }^{171}$ Como señala Tully: "Since the early nineteenth century, however, Locke's theory of property has played a major and contradictory role in western political thought. The early English and French socialists took it as the major philosophical foundation of modern socialism: the workers' right to the product of their labour and possession regulated by need. In the twentieth century the tables were turned; Locke became the spokesman for limited private property and, more recently, for unlimited private property. [...] Indeed, the term 'property' itself has a meaning different from ours. Locke's theory is neither socialist nor capitalist; our modern dichotomy of private and common has no place in it. The mutually exclusive concepts of common and private property divide the modern world into two spheres. By coming to understand a way of thinking about rights in which our opposed concepts do not exist, we can begin to see what is contingent and what is necessary in our predicament” (Tully, 1980: X). Más adelante, refiriéndose a la teoría de la propiedad de Locke aclara: "It is not [...] a 'justification of private property'. It is an attempt to work out this problem of the natural distribution of common property” (Tully, 1980: 3)

172 Producto, entre otras cosas, de la competencia de los Estado Nación alrededor de los territorios. 
Como se ve, el problema de la propiedad en Locke obedecía a circunstancias muy distintas a las que el liberalismo tendría que afrontar en el siglo XIX. Para éste último, el problema consistía en articular un dispositivo en el cual los individuos desposeídos pudieran ser presentados como sujetos con la capacidad de realizar contratos civiles de intercambio comercial. Sólo así los trabajadores asalariados podían ser considerados como individuos libres para intercambiar su trabajo en el mercado, aunque, al mismo tiempo, se encontraran sometidos a la dictadura patronal y al rígido imperio de la competencia ilimitada. En todo caso, un entramado de ideas semejante sólo pudo ser problematizado a finales del siglo XVIII, cuando el proceso de industrialización capitalista comenzó a transformar las relaciones sociales de Europa. ${ }^{173}$

\section{La singularidad del liberalismo decimonónico}

En realidad, el liberalismo moderno sólo se materializó como un proyecto económicopolítico más o menos coherente durante el siglo XIX. ${ }^{174}$ De hecho, la articulación de un discurso consistente, claramente diferenciado de sus adversarios políticos, puede datarse apenas en la década de 1830. Antes de ello, los trazos que definían sus contenidos y lo diferenciaban de otras corrientes no habían terminado de ser delineados. Durante la Restauración, los sectores conservadores no diferenciaban a los sectores liberales de los pensadores socialistas. En tanto partidarios de la “revolución”, ambos eran considerados como una amenaza contra el orden natural del mundo. ${ }^{175}$ Para la "reacción” conservadora,

\footnotetext{
173 En realidad, tanto las restricciones comerciales, como la reforma de la Ley de Pobres fueron condiciones indispensables para el desarrollo del liberalismo moderno. No obstante, la liberación total del mercado data de los años 1846 y 1847, cuando se abolen las leyes cerealeras y se suprimen las tasas que gravaban algunas materias primas (Cfr, Marx, Karl, El Capital...op.cit. p.342). Todavía en 1800 el proteccionismo económico era tan bien valorado en Gran Bretaña que, aun en detrimento de sus propios ingresos, los productores de algodón exigían al gobierno la prohibición de las exportaciones de hilado (Cfr. Polanyi, op.cit...p. 194). Algo semejante ocurría con la famosa Ley de Pobres cuyo funcionamiento impedía el libre acceso de los trabajadores al mercado. Aunque desde finales del siglo XVIII pensadores como Townsend, Burke y Bentham abogaban por la eliminación de la legislación isabelina, no fue sino hasta 1834 que ésta fue reformada en favor de la burguesía industrial (Cfr, Polanyi,... op.cit. p. 195ss; Wallerstein,... op.cit.)

${ }^{174} \mathrm{Al}$ respecto, remitimos al cuarto volumen de El sistema Mundo de Immanuel Wallerstein. De hecho, el uso político del término "liberalismo" data apenas de la segunda década del siglo XIX: “Como adjetivo con connotaciones políticas el término [liberal] parece haber sido usado por primera vez durante los años del Directorio francés [...] Todos parecen coincidir en que el adjetivo se convirtió en sustantivo en Cádiz, en 18101811, cuando se lo aplicó a un grupo de las Cortes españolas” (Wallerstein, 2010:22).

175 Este antagonismo sólo se volvió más patente después de las guerras napoleónicas, cuando, de la mano de Luis XVIII y Carlos X, la embestida conservadora se hizo del poder en Francia. Durante la Revolución francesa, según afirma Rémond, la verdadera disputa se localizaba entre los extremos de la República y la Monarquía, y,
} 
tanto liberales, como republicanos y socialistas ${ }^{176}$ representaban la aparición de una modernidad ${ }^{177}$ destinada a acabar con la organización racional de la sociedad hasta entonces dominante. De igual forma, en las primeras décadas del siglo XIX, tanto el liberalismo como el socialismo coincidían en su rechazo a ese espíritu conservador obsesionado con restaurar las instituciones del pasado. ${ }^{178}$ En realidad, fue sólo cuando la liberación del comercio y del trabajo mostraron sus efectos sobre las clases laboriosas que ambas posturas atestiguaron el abismo que las dividía.

Así, por ejemplo, cuando Claude Henri de Saint-Simon escribió sus trabajos críticos sobre la sociedad de su tiempo no intentaba desautorizar las ideas de los pensadores liberales. Antes bien, denunciaba que el cuerpo político de la Francia posrevolucionaria se hallaba en crisis debido a una transición incompleta entre un sistema feudal eclesiástico y uno científicomoderno. ${ }^{179}$ De hecho, coincidía con los liberales en que la sociedad francesa estaba tan hambrienta de modernidad que ni siquiera la Revolución había evitado que "una clase de aristócratas y curas holgazana y parasitaria cuya mentalidad derivaba de los poderes militares y teocráticos del feudalismo”"180 siguiera gobernando la nación. Ante semejante situación, Saint-Simon recomendaba trasladar el poder de las manos de los representantes del feudalismo a las de los industriales. ${ }^{181}$ Para él, estos últimos eran los verdaderos productores de la riqueza de una nación y, por lo mismo, les correspondía la tarea de reorganizar la

durante el periodo jacobino, entre la Revolución y la Contrarrevolución. (Rémond, René, Les droites en France, Aubier Montaigne, 1982, p.16).

${ }^{176}$ En el periodo de la monarquía de julio e incluso hasta 1848 existían al menos cuatro facciones a las que podía calificarse como grupos de "izquierda", sin embargo, en la jerga común todas se aglutinaban bajo el concepto de republicanos (Plamenatz, John, The Revolutionary Movement in France, 181-71, Lonmans, s, 1952,p. 47-49).

${ }^{177}$ En palabras de Immanuel Wallerstein: "[El conservadurismo] se planteaba el objetivo ya sea de revertir por entero la situación (en la versión dura) o de limitar el daño y detener lo más posible los cambios que se avecinaban (en la versión más sofisticada). Los conservadores creían que al imponer su esquema "racional", deductivo, del proceso político, los partidarios de la revolución (o de la reforma; para el dogma conservador no hay mayor diferencia), creaban confusión en la sabiduría de los tiempos y, por consiguiente, daño social” (Wallerstein., Immanuelle, El sistema...op.cit. p.23).

${ }^{178}$ Como señala Wallerstein, antes de 1830 las diferencias entre liberales y socialistas tenían más que ver con el grado de intensidad requerido para racionalizar las sociedades que con un ideario político bien definido. En todo caso, los liberales consideraban que la modernización de las sociedades requería un programa político basado en un "reformismo deliberado, continuo, inteligente" (Ibid.p.27), mientras que los socialistas pensaban que era preciso radicalizar las transformaciones sociales para eliminar todos los resabios del pasado.

${ }^{179}$ Cfr, Harvey, David, París...op.cit. p.89.

${ }^{180}$ Ibid.

181 Saint-Simón usaba el término industriales para oponerlo a la aristocracia feudal improductiva. En él, quedaban comprendidos tanto a obreros, como a campesinos, banqueros y propietarios de empresas. 
producción del trabajo útil a través de una administración racional y jerarquizada de la sociedad. ${ }^{182}$ Así, en su Catecismo político de los industriales el francés afirmaba:

Todos los industriales trabajan para producir y poner al alcance de la mano de todos los miembros de la sociedad todos los medios materiales para satisfacer sus necesidades o sus gustos físicos [...] La clase industrial debe ocupar el primer rango, por ser la más importante de todas, porque puede prescindir de todas las otras sin que éstas puedan prescindir de aquélla, porque subiste por sus propias fuerzas, por sus trabajos personales. ${ }^{183}$

Ciertamente, el francés reconocía el conflicto entre la clase ${ }^{184}$ industrial (en general todo trabajador con utilidad productiva) y los no propietarios, pero afirmaba que la administración racional del cuerpo político encomendada a los sabios y a los más capacitados resolvería este conflicto mediante la inclusión de todos en el trabajo productivo. De esta forma, la organización de los trabajadores productivos dejaría atrás el parasitismo de terratenientes y aristócratas para, finalmente, volver a poner sobre sus pies el cuerpo político de las naciones modernas:

Los industriales se constituirán en la primera clase de la sociedad; los más importantes de entre los industriales se encargarán, gratuitamente, de dirigir la administración de la riqueza pública; ellos serán quienes hagan la ley y quienes marcarán el rango que las otras clases ocuparan entre ellas; concederán a cada una de ellas una importancia proporcional a los servicios que cada una haga a la industria. Ta será, inevitablemente, el resultado final dela actual revolución; y cuando se obtenga este resultado, la tranquilidad quedará completamente asegurada, la prosperidad pública avanzará con toda la rapidez posible; y la sociedad disfrutará de toda la felicidad individual y colectiva a la que la naturaleza humana puede aspirar. ${ }^{185}$

Con el mismo entusiasmo que elogiaba los efectos benéficos de la industrialización y las virtudes de una administración jerárquica, Saint-Simon apostaba por las bondades de la organización de los trabajadores y la necesidad de construir una sociedad más igualitaria. Sin embargo, en el transcurso del siglo XIX estas ideas darán cauce a dos sendas de pensamiento divergentes, incluso contrapuestas. Los distintos caminos que tomaron los propios discípulos

\footnotetext{
182 Harvey,...op.cit.p.90.

183 Saint-Simon, Cladue Henri, Catecismo político de los industriales, Aguilar, México, 1964.p. 53-54.

${ }^{184}$ Mucho antes que Marx, Saint-Simon había echado mano del concepto de clase para analizar la composición social de su tiempo. En realidad, el concepto era habitual entre los que el marxismo denominó "historiadores burgueses”, como, por ejemplo, François Guizot. El propio Tocqueville se hará eco de esa categoría en sus trabajos históricos.

185 Ibid, p.84.
} 
de Saint-Simon dan cuenta de esta bifurcación. Influenciado por las ideas de autoorganización social y distribución equitativa del trabajo, Pierre Leroux defenderá una especie de asociacionismo cristiano; ${ }^{186}$ mientras que Enfantin y sus sucesores retomarán el carácter tecnocrático y pro-industrial de Saint-Simon para elogiar el espíritu empresarial de la nueva burguesía. $^{187}$

Así, en unos cuantos años, las circunstancias habían cambiado a tal punto que la coherencia interna del proyecto saint-simoniano parecía irreconocible. A partir de la década de 1830, la idea de un tránsito a la modernidad comandado por una clase industrial dispuesta a tomar en sus manos la organización del trabajo se presentaba como una contradictio in terminiis. De hecho, lo contrario parecía ser lo cierto: el desarrollo industrial se fundaba en una férrea oposición a cualquier forma de organización en el mundo del trabajo. Ahora, a diferencia de lo ocurrido durante la Restauración, la apelación a la modernidad resultaba insuficiente para definir una posición clara dentro del escenario político. Ciertamente, la liberación del comercio podía ser defendida como una vía para modernizar las estructuras de la sociedad, sin embargo, la exigencia de que los trabajadores asalariados dejaran de ser tratados como esclavos ${ }^{188}$ también era una forma de luchar contra los resabios más abyectos de un pasado que no terminaba de desaparecer.

Uno de los testimonios más claros de esta escisión puede leerse en el artículo publicado por Pierre Leroux el 18 de enero de 1831 en Le Globe, un periódico liberal en el que participaban algunos seguidores de la doctrina de Saint-Simon. Desde su fundación en 1824, Le Globe se había comprometido con “le príncipe de liberté [...] poussé á toutes ses consequénces en économie politique, en philosophie, en art”. ${ }^{189}$ Asentado en el "terrain de liberalisme”, ${ }^{190}$ el periódico declaraba su oposición a la Restauración y su deseo de promover

${ }^{186}$ Cfr, Leroux, Pierre, Aux philosophes, aux artistes, aux politiques. Trois discourses et autres textes, Éditions Payons \& Rivages, 1994, p.182ss.

${ }^{187}$ Sobre estos últimos Carlisle se expresa de la siguiente manera: "El radicalismo saint-simoniano consistía en su famosa decisión de modificar desde dentro la visión, las costumbres y las prácticas del mundo empresarial burgués liberal en la Francia posnapoleónica. Además, el radicalismo saint-simoniano consistía en llevar a ese mundo empresarial, regido por un concepto de una ley económica rígida [...] Los saint-simonianos fueron los creadores de una actitud de iniciativa, de asunción de riesgos, de expansionismo entre los hombres de negociosos franceses (Carlisle, 1968: 44-445).

188 Así, por ejemplo, Pierre Leroux afirmaba en 1832: «[...]ceux qui possèdent les instruments de travail tiennent ceux qui ne les possèdent pas dans un état de dépendance et de exploitation qui est la suite et la transformation de l'ancien esclavage» (Leroux, Pierre,...op.cit.p.186).

${ }^{189}$ Ibid, p. 66.

${ }^{190}$ Ibid.p.66. 
los avances del progreso humano. No obstante, la Revolución de Julio vendría a dar un vuelco total a la situación. Con el gobierno de Luis Felipe, afirmaba Leroux, se evidenciaba que "les doctrines économiques d'indifference et de laissez faire»191 eran totalmente contrarias al mejoramiento "morale, intelectual, et physique" de "la clase plus nombreuse et la plus pauvre”. 192

Ocurría, como señala Vincent Peillon, ${ }^{193}$ que las circunstancias de la década de 1820 permitían suspender las diferencias entre los sectores liberales y los sectores vinculados a las organizaciones de trabajadores. Sin embargo, hacia 1832, cuando la Monarquía de Julio había dejado sentir su fuerza sobre los trabajadores asociacionistas en nombre de la libertad de competencia, las cosas cambiarán por completo. Ese mismo año Leroux elevará el tono de su crítica a los economistas liberales, quienes comenzaban a dominar la escena en Francia:

Il s'était élevé sous la restauration une sorte de sciences vide et subtile qui avait osé prendre le nombre de la plus belle des sciences, et qui, sans cœur, sans yeux et sans oreilles, se prétendait pourtant la rectrice de la société ; on l'appelait l'économie politique [...] Son principe universel, son unique axiome était la liberté et la concurrence. ${ }^{194}$

Como la mayoría de los trabajadores que empuñaban la bandera de la fraternidad, Leroux sabía que, a pesar de levantarse sobre el sufrimiento de las clases más desfavorecidas, las aspiraciones de emancipación de unos pocos encontraban su legitimidad remitiéndose a esa ciencia cuyos axiomas eran la libertad y la competencia. Y es que, en realidad, el dispositivo liberal del siglo XIX sólo adquirió coherencia en relación a eso que Michel Foucault identificó como un nuevo régimen de veridicción para la gubernamentalidad estatal. Antes que una cantera de brillantes ideas políticas -a las que los autores contemporáneos suelen recurrir para hablar de las virtudes de la democracia moderna-, el liberalismo del siglo XIX fue un dispositivo de poder-saber en el cual la economía política jugaba un papel fundamental. Así, si se analiza con detenimiento, se verá que la condición de posibilidad que le da coherencia al "liberalismo político" (Constant, Guizot, Tocqueville, etc,) es la

\footnotetext{
191 Ibid.p.69

192 Ibid.p.189

193 Peillon, Vincent, Pierre Leroux et le socialisme Républicain, Le bord de l'eau, Bordeaux, 2003. p.61ss.

194 Ibid.p.182-183.
} 
existencia de una realidad inédita en el orden del saber: la del mercado autorregulado. ${ }^{195}$ Sólo porque esta realidad, inexistente hasta finales del siglo XVIII, se convirtió en una rejilla de análisis liberada de toda interferencia, la resolución de la llamada question social pudo ser problematizada por los sectores liberales más allá de una lógica que la vinculaba a las obligaciones políticas del Estado. Veamos.

\section{2.- El lugar del mercado en el dispositivo liberal}

En el curso de 1979 titulado El nacimiento de la biopolítica, Michel Foucault afirma que el siglo XVIII vio nacer una forma de gubernamentalidad que, gracias al saber de la economía política, encontró su límite interno en la figura del mercado. ${ }^{196}$ A diferencia de la Razón de Estado, esta nueva forma de gubernamentalidad estaba fundada en un conjunto de prácticas que no dependían de un principio de justicia sino de la distinción entre lo verdadero y lo falso. El francés asegura que, a mediados del siglo XVIII, el mercado comenzó a ser problematizado como un lugar que obedecía a mecanismos naturales. En la medida en que estos mecanismos respondían a leyes espontáneas y no a decisiones sobre la moralidad o la inmoralidad de la distribución de los recursos, la elección de la mejor forma de gobernar se sostenía menos en un criterio de justicia que en el mayor o menor grado de conocimiento sobre esos mecanismos. ${ }^{197}$ El francés pone de relieve la novedad de este “arte de gobernar” mostrando que la definición de su dinámica interna apela a un régimen de veridicción cuya condición de posibilidad es el nuevo papel que el mercado comienza a jugar a partir del siglo XVIII.

Ahora bien, Foucault localiza en los fisiócratas el punto de inflexión que separa lo que el llamará gubernamentalidad liberal de la Razón de Estado. Según el francés, fueron estos últimos los primeros en desplazar el eje de gravedad del gobierno hacia ese dominio de verdidicción representado por el mercado en relación al problema de la definición de los precios. Aunque Foucault tiene razón al afirmar que los fisiócratas inauguran un nuevo régimen de verdad, es necesario distinguir de forma todavía más precisa entre el significado y la función que un concepto como el de “orden natural” cumple entre los fisiócratas y la

\footnotetext{
195 Aunque nuestra interpretación no es idéntica a la de Foucault, en este punto seguimos su argumentación en la clase del 27 de enero de 1979 (Foucault, Michel, El Nacimiento de la biopolítica, Akal, Madrid, 2009, p. 39). 196 Ibid, p.42ss.

197 Ibid.p.41.
} 
singularidad del mismo en el liberalismo posterior. ${ }^{198} \mathrm{Si}$ es verdad que el discurso del liberalismo económico del siglo XIX sólo fue posible cuando el mercado se presentó como un objeto teórico bien definido, la forma en que este discurso puso en contacto sus enunciados con unos objetivos políticos y unas prácticas de poder peculiares -dispositivo de saber poderse distingue de la manera en que los fisiócratas hacían funcionar el concepto de orden natural.

\section{El orden natural de los fisiócratas}

En efecto, antes de que el liberalismo decimonónico colocara al mercado autorregulado en el centro de la economía moderna, los fisiócratas ya habían hablado de un “orden económico” natural. ${ }^{199}$ No obstante, ambos conceptos operaban en coordenadas teóricas distintas y respondían a problemas diferentes. ${ }^{200}$ Con frecuencia, suele afirmarse que la principal limitación de los fisiócratas consistió en imaginar el trabajo agrícola como la única actividad destinada a producir un “excedente” o, en sus propias palabras, un “producto neto”. Aunque esta perspectiva no es del todo errónea, impide comprender la coherencia interna de los planteamientos elaborados por los economistas franceses del siglo XVIII.

Más que presentar al trabajo agrícola como la fuente de todo excedente, los fisiócratas atribuían la riqueza de una sociedad a la propia Naturaleza. Ciertamente, ni el comercio ni la industria podían explicar la aparición del “producto neto”, ${ }^{201}$ sin embargo, el trabajo del agricultor tampoco daba cuenta de ese fenómeno. ${ }^{202}$ La actividad del trabajador agrícola -al igual que la del industrial- ${ }^{203}$ sólo servía para reponer los gastos de su propia subsistencia,

198 En ese sentido cabe afirmar que existen distintas maneras de establecer una relación entre los enunciados de verdad posibles y las prácticas de gobierno a las que éstos se encuentran vinculados.

199 Dobb, Maurice, Las teorías del plusvalor de Smith a Marshal, Siglo XXI, México, 2004.p.55

${ }^{200}$ Las historias de la economía tienden a afirmar que el famoso orden natural de los fisiócratas contenía el germen del mercado autorregulado descubierto posteriormente por los liberales, como si los economistas del siglo XIX simplemente hubieran desarrollado con precisión científica las ideas que los fisiócratas habían intuido ${ }^{201}$ Por excedente o producto neto, los fisiócratas entendían el resultado de aquella actividad económica capaz de producir un valor mayor a aquél que consume en el proceso. Cfr. Ekelund, Robert; Hébert, Robert, Historia de la teoría económica y de su método, McGraw-Hill, México, 1991. p.92.

202 En realidad, los fisiócratas consideraban que, más que generar un excedente, el comercio se dedicaba a distribuir la riqueza existente. Mientras que, en el caso de la industria, a pesar de que ésta producía objetos, no era capaz de crear un valor mayor al costo de producción.

203 Tanto si la industria determinaba sus precios libremente por medio de la competencia, como si lo hacía a través de monopolios era incapaz de generar más riqueza de la que permitía recuperar los costos de producción. En el primer caso, la competencia tendía a presionar los precios a la baja de manera que sólo podían retribuir los costos de producción, entre los cuales se encontraba la subsistencia del trabajador. Ciertamente, la existencia de monopolios, en el segundo caso, elevaba los precios en el comercio, sin embargo, este aumento no se debía a la creación de mayor valor sino a la transferencia al consumo. En ambos casos el trabajador industrial se limita a reponer con su labor el costo de su propia subsistencia bajo la forma de un salario, tanto si los precios 
pero, a diferencia del comerciante o el manufacturero, tenía la fortuna de laborar con la fuente misma de la riqueza: 204

La Agricultura -decía Mirabeau- es una manufactura de institución divina, en la que el fabricante tiene como socio al Autor de la naturaleza, al Productor mismo de todos los bienes y de todas las riquezas. ${ }^{205}$

De igual forma, Quesnay llamaba al soberano y a la nación a no perder jamás de vista que:

...la terre est l'unique source des richesses [...]. De cette source abondante dépend le succès de toutes les parties de l'administration du royaume. ${ }^{206}$

Dado que el excedente era producto de la Naturaleza -y no de los trabajadores agrícolas-, la política económica debía preservar la subsistencia de quienes garantizaban su reproducción, esto es, de los rentistas de la tierra. Ahora bien, las restricciones al comercio impuestas por las políticas mercantilistas disminuían los precios de los productos agrícolas y, consecuentemente, presionaban a la baja la renta de la tierra. De ahí que los fisiócratas defendieran la liberación comercial. Sin embargo, con ello no buscaban demostrar la capacidad de autorregulación de un mercado separado rígidamente de la actividad estatal, sino asegurar el aumento de los ingresos de los terratenientes con la finalidad de garantizar el aprovisionamiento de recursos para las cosechas futuras. ${ }^{207}$

En su famosa Tableu economique ${ }^{208}$ Quesnay había intentado mostrar que todo el proceso de circulación dependía de la actividad agraria. Sin embargo, no por ello defendía el

eran bajos como si aumentaban por la existencia de monopolios el costo del trabajo seguí siendo equivalente a sus gastos de subsistencia. Cfr. Foucault, Michel, Las palabras y las cosas, Siglo XXI, México, 2008, p.192ss. ${ }^{204}$ En las Teorías de la Plusvalía Marx afirmaba con razón que, para los fisiócratas: "la plusvalía aparece como una donación de la Naturaleza” (Marx, Karl, Teorías de la plusvalía II, FCE, México, 1980pp.142-143)

${ }^{205}$ Mirabeau, Philosophie rurale, p.56. Citado en: Foucault, Michel, Las palabras.... p. 193.

${ }^{206}$ Quesnay, François, Euvres complétés. Vol II. Institut National D’Études Démographiques, Paris, 1950. p.951.

207 Ibid.p.950.

${ }^{208}$ La famosa Tableu economique de Quesnay era un sofisticado cuadro numérico que representaba el flujo de la riqueza en la Francia de la segunda mitad del siglo XVIII. La Tabla presentaba a la agricultura como la única actividad que producía un excedente, mismo que debía servir para satisfacer las necesidades de los trabajadores del campo y los terratenientes, pero, también, de las clases improductivas. En su ejercicio teórico, Quesnay intentaba demostrar cómo circulaba ese excedente entre las diferentes clases y cómo se reproducía año con año (Roll, Eric, Historia de las doctrinas económicas, FCE, México, 1987,p.135). Semejante Tabla servía como un 
aumento de los salarios de los agricultores. El rumbo que, desde su perspectiva, debía adoptar la Monarquía francesa en materia económica era muy distinto. El Estado debía garantizar, en primer lugar, que los rentistas de la tierra tuvieran los ingresos suficientes para reiniciar constantemente el ciclo económico (y la liberación comercial era un instrumento útil para este objetivo); no obstante, era igual o más importante solventar los ingentes gastos del tesoro mediante una profunda reforma fiscal. ${ }^{209}$ Así, al mismo tiempo que desautorizaban las restricciones económicas instauradas durante el mercantilismo, ${ }^{210}$ los fisiócratas reivindicaban una organización social en la que el comercio y la industria se hallaban supeditados a las exigencias de la tierra y a las necesidades del poder estatal.

Ciertamente el Estado era concebido como una instancia con límites exteriores a los deseos arbitrarios del soberano, ${ }^{211}$ sin embargo, dichos límites no eran trazados por la voluntad del pueblo o por los derechos inalienables de los individuos. Eran impuestos, por el contrario, mediante eso que Quesnay propiamente denominaba como “orden natural”, esto es, el conjunto de normas establecidas por Dios para garantizar la reproducción y la distribución de los bienes requeridos con el fin de mantener a los hombres "reunidos en sociedad”. 212

Ahora bien, a pesar de que el francés señalaba que el “orden natural” estaba constituido por unas leyes físicas y unas leyes morales, ${ }^{213}$ hacía descansar la organización de todo el poder político sobre las primeras:

instrumento que pretendía otorgarle objetividad al análisis de la circulación mostrando cuál era su orden intrínseco, pero no coincidía con el papel del mercado en el liberalismo, en particular, porque, para estos últimos el análisis de la circulación de la riqueza consideraba a la actividad agraria como la única actividad productora de un excedente.

${ }^{209}$ Los fisiócratas eran favorables a una reforma fiscal que, paradójicamente, gravaba los impuestos a la renta de la tierra. En el razonamiento de los fisiócratas medida, sin embargo, no iba en perjuicio de los terratenientes, ya que los beneficios logrados mediante el aumento de los precios de los productos agrícolas sería tal que beneficiaría a los terratenientes aun con el aumento de impuestos.

${ }^{210}$ Cfr, Roll, ...op.cit, p. 137. También llamadas medidas colbertistas. Como Ministro de Finanzas de Luis XIV Colbert sostuvo que uno de los papeles fundamentales del Estado era el de promover la producción de riqueza, siguiendo este planteamiento, los sucesores de Colbert en el siglo XVIII defendieron la intervención estatal destinada a impulsar el desarrollo de la industria. En cambio, los fisiócratas consideraban que el Estado debía permitir que la riqueza circulara de tal forma que volviera a la actividad agrícola con el fin de que ésta pudiera impulsar nuevamente el ciclo económico.

211 "Cette autorité ne doit pas être abandonnée à un despote arbitraire ; car un telle domination forme un corps qui changerait succesivament de chef [...]» Quesnay, François ...op.cit. p. 918.

${ }^{212}$ En palabras de Quesnay: «Ce lois sont établies à perpétuité par l'Auteur de la nature, pour la reproduction et la distribution continuelle des biens qui sont nécessaires aux besoins des hommes réunis en société, et assujettis à l'ordre que ces lois leur prescrivent » (Quesnay, Francois,...op.cit. p. 918).

213 "Les lois constitutives des sociétés sont les lois de l'ordre naturel le plus avantageux au genre humain. Ces lois sont ou physiques ou morales [...]” (Ibid.p.917). 
La puissance législative, souvent disputée entre le souverain et la nation, n'n'appartient primitivement ni à l'un ni à l`autre ; son origine est dans la volonté suprême du Créateur et dans l`ensemble des lois de l'ordre physique il n`y a rien de solide, tout est confus et arbitraire dans l’ordre des sociétés [...]. Les lois naturelles de l'ordre des sociétés sont les lois physiques mêmes de la reproduction perpétuelle de biens nécessaires à la subsistance, à la conservation et à la commodité des hommes. ${ }^{214}$

Era sobre esta base analítica que, como es bien conocido, los fisiócratas defendían la necesidad de una “déspota ilustrado” en el orden político. En efecto, dado que el funcionamiento de las sociedades dependía de las exigencias objetivas de ese orden físico, el gobierno debía estar comandado por aquél que tuviera la capacidad de obedecer sus dictados. Así, en sus “Máximes génerales du gouvernement economique d’un royaume agricole”, escritas en 1774, Quesnay afirmaba

Que la nation soit instruite de lois générales de l'ordre naturel qui constituent le gouvernement évidemment le plus parfait. L'étude de la jurisprudence humaine ne suffit pas pour former les hommes d’État, il est nécessaire que ceux qui se destinent aux emplois de l'administration soient assujettis à l'étude de l'ordre naturel. ${ }^{215}$

En el fondo, como este “orden natural” definía el funcionamiento racional de la sociedad, la autoridad del soberano debía someterse por entero a esta realidad antes que a cualquier interés particular:

[...] l'autorité souveraine [est] unique, et supérieure à tous les individus de la société et a toutes les entreprises injustes des intérêts particuliers. ${ }^{216}$

En ese sentido, los fisiócratas representaban una posición crítica respecto a los defensores del absolutismo en tanto que partían de una concepción de la sociedad donde la voluntad del soberano estaba limitada; sin embargo, esa limitación le venía de un orden fundado en unas reglas objetivas producidas por la propia naturaleza y no de su respeto a lso derechos de los individuos o de su conformidad con los intereses particulares de los seres humanos. El liberalismo decimonónico, en cambio, funcionará desde unas coordenadas

\footnotetext{
${ }^{214}$ Quesnay, François, ,...op.cit.p.921.

215 Ibid.

216 Ibid.p.949.
} 
distintas. Sin duda, el desarrollo económico dependerá de un conjunto de leyes naturales, pero éstas sólo serán denominadas de esta manera por haber surgido de forma consustancial a la interacción de los hombres con su entorno una vez que la libertad y la propiedad han sido aseguradas. De esta forma, será la interacción libre de los intereses particulares la única forma de hacer inteligible una realidad económica regulada por leyes objetivas. De ahí que, para el liberalismo decimonónico, la liberación del mercado será, a la vez, un proyecto económico y una apuesta jurídico-política destinada a garantizar la libertad de los individuos en la esfera civil. ${ }^{217}$ Sin embargo, en el espacio del saber abierto por los fisiócratas ${ }^{218}$ esta vinculación no había terminado de anudar sus amarres. ${ }^{219}$

\section{Adam Smith con un pie dentro y otro fuera del liberalismo}

Aunque es verdad que Quesnay hizo gravitar el sistema de gobierno sobre el eje de la “verdad”, la importancia que los fisiócratas atribuían a la Naturaleza y al poder del Estado resultan incompatibles con el liberalismo posterior. Algo similar ocurrirá con la obra de Adam Smith, en la Investigación acerca de la naturaleza y causas de la riqueza de las naciones, el escocés ciertamente coloca sobre la mesa algunos temas recurrentes del liberalismo decimonónico, sin embargo, los resortes que marcan las fronteras entre el Estado y el mercado o el papel otorgado al trabajo obedecen a argumentos muy diferentes a los que apenas unas décadas después esgrimirán autores como Malthus, Say, Senior o Bastiat. Contrario a lo que se acostumbra a creer, la famosa obra del escoces no tenía el objetivo de

${ }^{217}$ El razonamiento era transparente: si no se garantizaban los derechos que permitieran la libertad de los individuos en la esfera civil -incluido el derecho a que el Estado no intervenga en ninguna instancia comercial, el funcionamiento racional del mercado se volvía imposible.

${ }^{218}$ En ese sentido, Karl Polanyi afirma con razón: [...][el] ordre natural [de los fisiócratas] no era más que un principio directivo para la regulación de la industria y la agricultura por un gobierno supuestamente todo poderoso y omnisciente [...] La idea de un sistema autorregulador de mercados ni siquiera se les había ocurrido (Polanyi,...op.cit. p. 193-194).

${ }^{219}$ No será sino hasta finales del siglo XVIII que las coordenadas de la economía política cambiarán profundamente hasta que, a mediados del siglo XIX sus problemas se verán reducidos al funcionamiento de mercado supuestamente autorregulado en todos los ámbitos Incluso antes, en fecha tan temprana como 1835 algunos pensadores católicos de izquierda acusaban a esa disciplina que únicamente se ocupaba "de cómo se acumulaba la riqueza y [no de] discutir el hecho de que la misma estaba mal distribuida” (Wallerstein, Immanuelle, El Sistema... op.cit.p.341). Marx vio con más lucidez que nadie este fenómeno, en el Epílogo a la Segunda edición de El Capital narra el desarrollo que tomó la economía política científica hasta el primer cuarto del siglo XX. Inmediatamente después señala que, cuando la burguesía tomó el poder en 1830, "las campanas tocaron a muerto” por la economía científica. 
elogiar la racionalidad del libre mercado sobre la ineficiencia de la acción gubernamental. ${ }^{220}$ En realidad, la Investigación... formaba parte de un proyecto más amplio cuya finalidad era:

[...] suministrar una relación de los principios del derecho y del gobierno, y de las diferentes revoluciones que estos han experimentado en las diferentes épocas de la humanidad, especialmente referida a la policía, a los ingresos públicos y a la defensa. ${ }^{221}$

Por lo mismo, el texto estaba construido sobre amplios estudios históricos, jurídicos y políticos que otorgaban las bases para una historia de la riqueza, la cual pretendía ayudar a los gobernantes a diseñar leyes que favorecieran una mejor distribución de los ingresos. En ese sentido, la obra de Smith no se dejaba reducir a un modelo para el funcionamiento del mercado y, mucho menos, a un modelo que asumiera la miseria de los trabajadores industriales como condición necesaria para el crecimiento económico. De hecho, en el texto publicado en 1776, Smith se mostraba contrario a la teoría salarial dominante en su época. Esta última, defendía la necesidad de mantener los salarios bajos con el objetivo de aumentar la industriosidad de los pobres ${ }^{222}$ y mantener una balanza comercial favorable. ${ }^{223}$ El escocés, en cambio, consideraba que los salarios altos eran un instrumento fundamental para promover la actividad productiva de los trabajadores y, con ello, aumentar la riqueza social:

Los salarios del trabajo -afirmaba Smith- son un estimulante de la actividad productiva, la cual, como cualquier otra cualidad humana mejora proporcionalmente al estímulo que recibe. Una manutención abundante aumenta la fortaleza corporal del trabajador, y la agradable confianza de mejorar su condición, así como la de acabar sus días en plenitud y desahogo, le animan a movilizar todos sus esfuerzos. En consecuencia, nos encontramos que allí donde los salarios del trabajo son crecidos, los obreros son más activos, diligentes y expeditivos que donde son bajos; [...]. ${ }^{224}$

\footnotetext{
${ }^{220}$ En efecto, a pesar de que Adam Smith terminará pasando a la historia como el padre del libre mercado, ni él ni David Ricardo habrían defendido dogmáticamente las políticas encumbradas por el liberalismo decimonónico. Como señala Wallerstein: "Smith no era un defensor doctrinario del laissez faire [...] no creía que el laissez faire fuera siempre bueno o siempre malo [...] Además Smith mismo había socavado lo ue suele considerarse su principal argumento en pro del laissez faire al demostrar que el orden natural cuando se le permite seguir su propio curso, en muchos aspectos funciona en contra y no a favor del bienestar general2 (Wallerstein, Immanuelle. El Sistema....op.cit.p.151).

${ }^{221}$ Méndez, Victor, El filósofo y el mercader. FCE, México, 2004, p. 311.

${ }^{222}$ Así lo pensaba Hume, por ejemplo, quien afirmaba que en la época de escasez los salarios son más bajos y "los pobres trabajan más, y realmente viven mejor que en lso años de abundancia, cuando se dedican a la pereza y a hacer motines”. Y más explícitamente Arthur Yung: "Todo el mundo sabe excepto un idiota que hay que conservar pobres a las clases bajas o nunca serán industriosas” (Himmelfare,...op.cit.p.66).

${ }^{223}$ Cfr.Ibid.p.66.

${ }^{224}$ Smith, Adam, Investigación acerca de la naturaleza y causas de la riqueza de las naciones, FCE., México, 2006, p. 79.
} 
El oriundo de Kirkaldy suponía que el aumento de los salarios sólo era posible si se acababa con los obstáculos que impedían la libre circulación del trabajo. De ahí su rotunda oposición a la Ley de Asentamiento de 1662, la cual limitaba la asistencia del gobierno a aquellos pobres que demostraran tener una residencia permanente. En el fondo, esta medida desincentivaba la movilidad de los trabajadores y, consecuentemente, impedía el crecimiento de la industria. Smith creía que la libre circulación del trabajo y la liberación comercial ${ }^{225}$ derivarían en una expansión de la riqueza que, a su vez, llevaría a la nación a un "periodo de progreso”. En este periodo, los trabajadores más empobrecidos encontrarían condiciones más propicias para el mejoramiento de su situación que aquellas que les ofrecía el gobierno mediante la asistencia:

Es digno de notarse también que durante un periodo de progreso -o sea mientras la sociedad avanza hacia ulteriores periodos de riqueza- [...] es cuando la situación del pobre laborioso [working poor] -es decir, de la gran masa de la población- se revela como más feliz y confortable [...]. El progresivo es, en realidad, un estado feliz y lisonjero para todas las clases de la sociedad. ${ }^{226}$

Ahora bien, para llegar a esta peculiar comprensión del papel del trabajador en la economía moderna Smith había tenido que desplegar un sistema de análisis basado en la existencia de lo que él llamará un precio natural. Aunque semejantes en más de un elemento, las consecuencias que Smith sacará de esta manera de abordar la realidad económica, serán distintas a las del liberalismo posterior. De ahí que no resulte del todo cierta la habitual interpretación que coloca a Smith en el mismo plano de análisis que los autores del siglo XIX. Veamos.

\footnotetext{
${ }^{225}$ El autor de la Teoría de los sentimientos morales asumía que una vez que el mercado se impusiera en condiciones óptimas para su adecuado funcionamiento la desigual asignación de recursos tendería a disminuir de forma paulatina. Y es que, desde su perspectiva, el correcto desarrollo del mercado tendería a incrementar la productividad, a lo que se sucedería un crecimiento de la riqueza nacional, un aumento en los salarios y, como consecuencia lógica, un estímulo en el consumo, el cual aseguraría la profundización de este círculo virtuoso.

${ }^{226}$ Smith, Adam, La riqueza... op.cit.p.79.
} 


\section{Precio natural y mercado en Adam Smith}

Como es bien sabido, Smith iniciaba su Investigación... afirmando que la riqueza es el resultado del proceso de trabajo y no ya el producto de la Naturaleza:

El trabajo anual de cada nación es el fondo que en principio la provee de todas las cosas necesarias y convenientes para la vida, y que anualmente consume el país. Dicho fondo se integra siempre, o con el producto inmediato del trabajo, o con lo que mediante dicho producto se compra de otras naciones. ${ }^{227}$

No obstante, cuando pasaba de esta consideración general a analizar la distribución del valor en las mercancías, el escocés recurrirá a una explicación fundada en la existencia de un precio natural. En la Investigación..., Smith definía el precio natural como aquél que permite pagar la renta de la tierra, los salarios del trabajador y el beneficio del capital, incorporados en una mercancía:

Cuando el precio de una cosa es, ni más ni menos, que el suficiente para pagar la renta de la tierra, los salarios del trabajador y los beneficios del capital empleado en obtenerla, prepararla y traerla al mercado, de acuerdo con sus precios corrientes, aquella se vende por lo que se llama precio natural. 228

Ahora bien, Smith consideraba que sólo cuando la oferta en el mercado coincidía con la demanda efectiva, el precio natural podía realizarse y, consecuentemente, las mercancías podía venderse a su valor y no a uno mayor. ${ }^{229}$ En otras palabras, sólo en la medida en que el número de compradores con posibilidad de reponer el gasto del costo de la renta de la tierra, el salario del obrero y los beneficios del capital inherentes a una mercancía coincidan con la cantidad de esas mercancías ofertada en el mercado, las cosas se podían vender a su valor. En un escenario así, pensaba Smith, resultaba imposible obtener un precio inferior al que naturalmente le corresponde a una mercancía o, por el contrario, venderla a un precio superior. Esta imposibilidad no era casual, sino que se fundaba en los efectos de la competencia, ya que ésta servía como un eficaz mecanismo para evitar el incremento deliberado de los precios:

\footnotetext{
${ }^{227}$ Smith, Adam, Investigación...op.cit.p.3.

${ }^{228}$ Ibid. p. 54.

${ }^{229}$ Cfr. Ibid.p55
} 
[En esta situación] toda mercancía se vende a ese precio [el precio natural], sin que se pueda obtener otro más alto. La competencia obligará a los traficantes a aceptar este precio, pero no otro menor. ${ }^{230}$

Así, según el oriundo de Kikaldy, un mercado funciona de manera óptima cuando las mercancías que circulan en él se venden a su precio natural -es decir, ni por encima de su valor ni por debajo de él- para lo cual resultan fundamentales las condiciones que permitan una competencia libre. En un escenario donde el mercado sea capaz de desarrollarse de forma óptima la intervención del Estado en lo tocante a la determinación de la oferta de productos o la regulación de los precios se vuelve un lastre semejante a aquél que representan los monopolios, ${ }^{231}$ ya que ambos impiden que las mercancías se estabilicen a su precio natural. ${ }^{232}$

Pero si el precio de una mercancía era definido por Smith en función de la renta, el salario y el beneficio, faltaba saber cómo se distribuía entre cada uno de estos factores. Es sabido que en La Riqueza... Smith distinguía entre dos estados: uno “originario” donde el producto del trabajo pertenecería de manera íntegra al trabajador y uno posterior que resultaría de los procesos de apropiación de la tierra y de acumulación de capital. En este segundo estado, característico de las sociedades modernas, el valor de la mercancía debía distribuirse mediante la sumatoria de cada uno de estos tres factores según su valor en el mercado, de finido, a su vez, en función de las variaciones de la oferta y la demanda.

No obstante, según Smith, en el caso particular del salario existe una peculiaridad: es resultado de un acuerdo contractual desigual. En efecto, su origen mismo está fundado en un contrato que habitualmente se establece en circunstancias de franca desventaja para los obreros:

Los salarios del trabajo dependen generalmente, por doquier, del contrato concertado por lo común entre estas dos partes, y cuyos intereses difícilmente coinciden. El operario desea sacar lo más 'posible, y los patronos dar lo menos que puedan. Los obreros están siempre dispuestos a concertarse para elevar los salarios y los salarios para rebajarlos.

\footnotetext{
230 Ibid.

${ }^{231}$ Ibid.p. 58

232 Sin embargo, el propio Smith admitía que la ausencia de intervención por parte del Estado sólo tenía sentido en un mercado con estas características: en los momentos en que, debido a la variación en la oferta o la demanda de algún producto, esto no ocurría, el aparato gubernamental debía intervenir en beneficio del bien públicoTal como afirma Leonardo Lomelí: “Cuando existen factores económicos o políticos que no permiten que el intercambio se dé en un ambiente competitivo entre productores [...], los mercados fallan, y como reconoce el propio Smith [...] el Estado ocupa un lugar importante” (Cordera, Rolando; Ramírez, Kuri; Ziccardi, Alicia, (coomp.), Pobreza, desigualdad y exclusión social en la ciudad del siglo XXI, Siglo XXI, México, 2012.p.53).
} 
Sin embargo, no es difícil de prever cuál de las dos partes saldrá gananciosa en la disputa, en la mayor parte de los casos, y podrá forzar a la otra a contentarse con sus términos. Los patronos, siendo menso en número, se pueden poner de acuerdo más fácilmente, además de que las leyes autorizan sus asociaciones o por lo menos no las prohíben. ${ }^{233}$

Llama la atención que esta admisión haya desaparecido por completo en los autores liberales posteriores, quienes harán del contrato salarial la expresión misma de la libertad y la igualdad. En cualquier caso, a esta constatación Smith agregaba que los bajos precio del salario, consustanciales a una negociación desventajosa, no podían caer más allá de los límites establecidos por los gastos de subsistencia de los propios trabajadores:

Pero aun cuando en las disputas con los trabajadores gocen generalmente de ventaja de los patronos, hay, no obstante, un cierto nivel por bajo del cual parece imposible que baje, a lo largo del tiempo, el salario corriente días ocupaciones de inferior categoría. El hombre ha de vivir de su trabajo y los salarios han de ser, por lo menos, lo suficientemente elevados para mantenerlo. ${ }^{234}$

De esta forma podría suponerse que los costos de subsistencia pasarían a ser interpretados como el precio natural del salario al que peste debía someterse por las exigencias del mercado. No obstante, a diferencia de lo que ocurrirá más tarde, en Smith los costos de subsistencia únicamente señalan el umbral por debajo del cual el salario no puede caer. En los hechos, el precio del trabajo está directamente relacionado con la demanda de trabajadores asalariados dentro de una sociedad. Así, en la medida en que esta demanda crezca, el precio de salario tendería a subir alejándose de los costos de subsistencia. Es por ello que, aun estando consciente de la inequidad originaria del contrato entre obreros y patrones, Smith suponía que el aumento de la demanda de trabajadores llevará a deshacer la coalición entre empleadores que los movía a bajar el precio de los salarios.

De ahí, la importancia que Smith le asigna al crecimiento de la riqueza y a la necesidad de aumentar continuamente el capital de un país. Desde su perspectiva, sólo cuando una sociedad aumenta su crecimiento, la demanda de trabajo crece, lo cual permite romper la perniciosa colusión establecida por los industriales y aumentar el precio del salario:

\footnotetext{
233 Smith, Adam, Investigación...op.cit.p.65

234 Ibid.p.66
} 
Cuando en un país aumenta continuamente la demanda de aquellas personas que viven de su salario [...] se rompe la natural coalición de los patronos para no subir los jornales [...] la demanda de mano de obra asalariada aumenta necesariamente con el aumento del ingreso y del capital de las naciones, y no puede aumentar sino en ese caso. ${ }^{235}$

Aunque, como vimos, Smith es uno de los primeros economistas en afirmar que el trabajo es la fuente de toda Riqueza, la definición del salario se encuentra estrechamente ligada a las condiciones de la demanda en el mercado. Es verdad que esto lo llevaba a analizar el papel del trabajo como si se tratara de una mercancía, sin embargo, Smith era consciente, por un lado, de que el intercambio de esa mercancía llamada trabajo se daba en el marco de unas condiciones desfavorables que, en un principio, no podían ser consideradas como igualitarias; y, por otro lado, las consecuencias teóricas de su estudio, lo llevaban a imaginar que, al propiciar la expansión de la industria, la nación entraría en un "periodo de progreso" en el que la miseria y la desigualdad tenderían a disminuir paulatinamente debido a la mejora de los salarios. Así, el hecho de que el trabajo estuviera sometido a los efectos del mercado no era interpretado necesariamente como una mala noticia para los trabajadores: siempre que hubiera aumento en la demanda de trabajo, se rompería esa coalición patronal que, entre otras cosas, hacía disminuir el precio del trabajo originando una situación que no correspondía a la naturaleza de un mercado plenamente libre, al menos no como lo imaginaba Smith.

Es cierto que, empapado de las ideas de la ilustración escocesa, Smith concebía el comercio como un instrumento de coordinación de los intereses particulares ${ }^{236}$ capaz de

\footnotetext{
235 Ibid.p.68

${ }^{236}$ El papel que Smith le asignó al comercio no fue el resultado de aislar un objeto de análisis para su estudio meramente científico, ni una conquista obtenida gracias a la aplicación de métodos cada ve z más rigurosos a la economía, métodos supuestamente ajenos a una concepción moral. En realidad, el papel del comercio en Smith era deudor de ideas filosóficas desarrolladas en el seno de la ilustración escocesa. Durante el siglo XVIII, semejante tradición trató de pensar un tipo de organización social asentada en la coordinación de las inclinaciones privadas, con lo cual intentaba evitar la infértil tarea de construir artificialmente instituciones que pretendían representar la voluntad colectiva (Rosanvallon, Pierre, El capitalismo utópico, Nueva Visión, Buenos Aires, 2006,p. 15ss). Tanto el cambio de significado de la noción de interés, como la utilización del concepto de simpatía fueron fundamentales para esta concepción. Habitualmente, el interés se entendía como un vicio personal ligado al lucro; sin embargo, la ilustración escocesa comenzó a pensarlo como una inclinación destinada a satisfacer las necesidades naturales de los individuos. A la par, el concepto de simpatía mostraba que existía una armonía natural entre los hombres independientemente de ese artificio político llamado Estado. En el Tratado sobre la naturaleza humana, por ejemplo, Hume escribía: "Ninguna cualidad de la naturaleza humana es más notable, a la vez en sí misma y en sus consecuencias, que la tendencia natural que tenemos a simpatizar con los otros y a recibir por comunicación sus inclinaciones y sus sentimientos por diferentes que sean de los nuestros” (Citado en: Rosanvallon, Pierre...op.cit.). De igual manera, en su Teoría de los sentimientos morales, Smith argumentaba: "Por más egoísta que quiera suponerse al hombre, evidentemente, en su naturaleza, hay algunos sentimientos que lo hacen interesarse en la suerte de los otros, de tal modo que la felicidad de estos le es necesaria” (Citado en: Ibid.).
} 
promover el bienestar colectivo. Sin embargo, su imagen de la sociedad comercial estaba muy lejos de asemejarse a la que tendrán los autores liberales del siglo XIX y, todavía más, los economistas neoliberales del siglo XX. En realidad, la liberación del mercado no era entendida en sí misma como un objetivo, mucho menos, como algo que debía defenderse al margen de sus efectos sociales. ${ }^{237}$ Antes al contrario, la eliminación de las restricciones a la circulación del trabajo sólo era una condición que, desde su perspectiva, ayudaría a realizar el verdadero objetivo: alcanzar un periodo de progreso en el que mejorarían las condiciones de vida de los trabajadores asalariados.

Sólo tardíamente Smith comenzó a ser leído como un férreo opositor a la intervención estatal en favor de un mercado supuestamente todopoderoso. Esta lectura, sin embargo, suele omitir que el escocés consideraba que el mercado debía ayudar a proveer al Estado de los “ingresos suficientes para mantener los servicios públicos”, ${ }^{238}$ así como “para suministrar al pueblo una abundante renta o subsistencia [y] habilitar a sus individuos y ponerlos en condiciones de lograrlo por sí mismos”. ${ }^{239}$ De hecho, Smith aconsejaba al legislador intervenir en actividades de la esfera económica como la regulación del dinero y el crédito, ${ }^{240}$ con el fin de producir condiciones propicias para el mejoramiento de las clases trabajadoras.

Sin duda, los efectos reales de la industrialización capitalista en el siglo XIX contradicen el optimismo smithiano, pero muestran que en el marco de su trabajo intelectual

${ }^{237}$ Cuando, medio siglo después de la publicación de la Investigación..., fueron reformadas las leyes de pobres, incluyendo la ley de asentamientos, no sólo no mejoraron las condiciones de vida de los trabajadores, sino que tales transformaciones colocaron a los trabajadores en una condición de dependencia más grave de aquella que el propio Smith intentaba combatir. Ocurría, sin embargo, que los efectos de la industrialización capitalista no podían haber sido previstos en una construcción teórica pensada para las características de la Europa del siglo XVIII. En su monumental obra Transformar el mundo. Revoluciones burguesas y revolución social, Neil Davidson retoma los estudios de David MacNally para señalar que la defensa del libre comercio de Smith suponía una comunidad de base agraria, en ella un Estado dirigido debía ayudar a desarrollar el potencial de un capitalismo agrario destinado a satisfacer el bienestar colectivo (Davidson, Neil, Transformar el mundo. Revoluciones burguesas y revolución social, Pasado \& Presente, Barcelona, 2013,p.127).

${ }^{238}$ En el libro quinto de la Investigación..., por ejemplo, Smith consideraba que el Estado debía combatir los perniciosos efectos del trabajo industrial mediante el financiamiento de instituciones educativas destinada a las masas populares (Smith,...op.cit.p. 687ss).

${ }^{239}$ Arrighi, Giovanni, Adam Smith en Pekin, Akal, Madid, 2007, p.52.

${ }^{240}$ Como afirma Polanyi, para Smith la riqueza $-y$, con ella, el mercado- era una instancia del cuerpo social entre otras: [La riqueza]era simplemente un aspecto de la vida de la comunidad, a cuyos fines continuaba subordinada: era una cara de las naciones que luchaban por sobrevivir y no podía ser disociada d ellas. En su opinión un juego de las condiciones que gobernaban la riqueza de las naciones se derivaba del estado próspero, estacionario o decadente del país en general; otro juego se derivaba del predominio de la seguridad así como de las necesidades del equilibrio de poderes; otro más era dado por la política del gobierno al favorecer a las ciudades o al campo, a la agricultura o a la industria; de ahí que sólo consideraba posible, dentro de una estructura política dada, formular la cuestión de la riqueza (Polanyi, Karl, La Gran...op.cit.p.165). 
el libre mercado estaba asociado a una realidad muy distinta a aquella que tendrá lugar en el siglo IX. Aunque es imposible saber hasta qué punto Smith hubiera reformulado sus ideas ante la situación de evidente deterioro por parte de los obreros, no lo es, en cambio, conocer los argumentos que llevaron a los autores del siglo XIX a defender la libertad de industria y la libertad de trabajo a pesar de ser conscientes de las terribles condiciones en que comenzaban a vivir los trabajadores industriales.

\section{El mercado como mecanismo natural}

Muy distintos a los de Smith serán los argumentos de A Dissertation on the Poor Laws, publicados por Joseph Towsend dos décadas después de que apareciera la Investigación.... Como lo indica el título de su trabajo, se trataba de un análisis sobre las leyes de pobre vigentes en Inglaterra desde el siglo XVII. Sin embargo, a diferencia de Smith -quien se limitaba a criticar la Ley de Asentamiento de $1662-{ }^{241}$ el reverendo inglés se oponía a toda la legislación isabelina argumentando que la asistencia pública impedía "que los pobres conocieran la necesidad”. 242

Por lo mismo, Towsend exigía una reforma para disminuir paulatinamente la asistencia del gobierno hasta que ésta desapareciera en su totalidad. ${ }^{243}$ Así, pensaba, cuando los hombres no tuvieran ninguna ayuda exterior, la necesidad los obligaría a trabajar. De esta forma, no sólo ganarían su independencia respecto al poder estatal, sino que aprenderían las virtudes de la industriosidad y la sobriedad inherentes a la actividad laboral: ${ }^{244}$ el aguijón de la necesidad servía, a la vez, como aliciente moral e instrumento económico.

${ }^{241}$ Cfr. Himmelfarb,...op.cit..p.76.

${ }^{242}$ En Inglaterra, las leyes de pobres fueron aprobadas en 1601 bajo el mandato de la reina Isabel I. Con ellas se habilitaba un sistema ejecutado por las parroquias que se financiaba con un impuesto local sobre la propiedad inmobiliaria ("poor rate"). En esencia, las leyes de pobres intentaban "otorgarle trabajo a los desempleados, enseñar un oficio a los niños, asistir a los pobres incapacitados para el trabajo, y castigar o corregir a los mendigos aptos para el trabajo que no querían trabajar" (Ramos, 2013: 120). En 1662 se promulgó la Ley de Asentamiento que restringía la asistencia a quienes pudieran demostrar su residencia permanentemente en una parroquia, con lo cual, se impedía la libre circulación de trabajadores potenciales.

${ }^{243}$ En su propuesta de reforma Towsend abogaba por una disminución paulatina de las ayudas a los pobres: "Para promover la industria y la economía, es necesario que el alivio de los pobres sea limitado y precario" (Citado en: Ramos, Gorostiza, “Joseph Towsend y la cuestión de los pobres en la España Ilustrada” en: Hispanic enlightenment, Vol. 36, $\mathrm{N}^{\circ}$ 1, 2013, p. 121). Sólo de esta manera las clases desfavorecidass podían tener contacto con la necesidad misma que los obligaría, de forma natural, a dejar el camino del ocio para insertarse en la laboriosidad.

${ }^{244}$ Una vez que los pobres fueran dirigidos al ámbito del trabajo, las ayuda debía restringirse a los impedidos para trabajar, pero éstas no debían correr por cuenta del gobierno, sino que debían depender de la caridad: “[...] aliviar a los pobres a través de donaciones voluntarias no sólo es lo más sabio, prudente y justo; [...] sino que 
Para ilustrar su argumento, Towsend recurría al llamado "teorema de las cabras y los perros”. El abate recordaba a la historia de Juan Fernández, quien, con el fin de garantizar un suministro de carne para sus futuros viajes, desembarcó un conjunto de cabras en una isla ubicada en los alrededores de Chile. En contra de todas sus expectativas, las cabras se multiplicaron de forma excesiva haciendo que la isla se volviera una fuente de alimentos gratuitos para los corsarios ingleses. Ante semejante circunstancia, la solución del gobierno español, consistió en enviar a la isla a un perro y a una perra. Con el paso de los años, los caninos se reprodujeron en la isla, no obstante, debido a que las cabras habían huido a las partes más rocosas de la isla, sólo los más dotados pudieron sobrevivir. De esta forma, sin necesidad de ninguna ley humana, se había instaurado un equilibrio natural en la población de perros y cabras atendiendo exclusivamente las dinámicas de la necesidad. ${ }^{245}$

Ahora bien, este elaborado teorema le servía a Towsend como ejemplo para criticar la ineficacia de las leyes de pobres:

El hambre -afirmaba- amansará a los animales más feroces, enseñará decencia y buena educación, obediencia y sujeción a los más perversos. En general, solamente es el hambre lo que puede animarlos y acicatearlos a trabajar; y sin embargo nuestras leyes han dicho que nunca sufrirán hambre. Las leyes, preciso es confesarlo, han dicho también que serán obligados a trabajar. Pero en este caso la compulsión legal suele ir acompañada de grandes disturbios, violencia y tumulto; crea mala voluntad y nunca puede aceptar un principio bueno y aceptable; mientras que el hambre no sólo es una presión pacífica, silenciosa y continua, sino que, como el motivo más natural del trabajo, da lugar a los esfuerzos más intensos [...] El esclavo debe ser obligado a trabajar, pero el hombre libre debe ser librado a su propio juicio y albedrío; debe ser protegido en el pleno disfrute de lo suyo, sea poco o mucho; y castigado cuando invade la propiedad de su vecino. ${ }^{246}$

Al afirmar que el hambre regula la pobreza de manera más “pacífica, silenciosa y continua” que la “compulsión legal” de los seres humanos, Towsend cambiaba sustancialmente las coordenadas de la economía política. Mientras que Smith pensaba el funcionamiento interno del comercio como un instrumento del legislador para lograr el bienestar colectivo, el reverendo inglés sostenía que la capacidad autorreguladora de la

es lo más efectivo a la hora de prevenir la miseria, y lo más excelente en sí mismo, dado que despierta [...] los afectos más amables del pecho humano, piedad, compasión y benevolencia en los ricos, amor, veneración y gratitud en los pobres”. (Citado en: Ibid.p.121).

${ }^{245}$ Cfr, Polanyi, Karl,...op.cit.p.167.

${ }^{246}$ Citado en: Ibid, p.168 
naturaleza permitía resolver un problema como la pobreza con mayor éxito que cualquier legislación humana. ${ }^{247}$

Sobre esta idea gravitará buena parte de las reflexiones de los economistas posteriores. En el Ensayo sobre la población, por ejemplo, Malthus colocará a la economía en el dominio de "las ciencias naturales”. Así, en el primer capítulo de obra, publicada en 1798, el inglés enuncia las dos “leyes naturales” que enmarcan toda su reflexión económica:

Primero: el alimento es necesario a la existencia del hombre. Segundo: la pasión entre los sexos es necesaria y se mantendrá prácticamente en su estado natural. Estas dos leyes que han regido desde los tiempos más remotos del conocimiento humano, aparecen como dos leyes fijas de la naturaleza. ${ }^{248}$

Ahora bien, se ve con claridad que a diferencia de los fisiócratas, el inglés no entendía por naturaleza un orden físico, sino una regularidad inherente al desarrollo social de los seres humanos. Partiendo de estas leyes socio-naturales, Malthus deducía la idea que lo ha hecho célebre hasta nuestros días, a saber: que, en ausencia de obstáculos, la población tiende a crecer más que los recursos a su disposición:

Considerando aceptados mis postulados, afirmo que la capacidad de crecimiento de la población es infinitamente mayor que la capacidad de la tierra para producir alimentos para los hombres. La población, sino encuentra obstáculos, aumenta en progresión geométrica. Los alimentos sólo aumentan en proporción aritmética. ${ }^{249}$

Así, la subsistencia de la población estaba inevitablemente sujeta a eso que Malthus denominaba como “una fuerte y constante presión restrictiva”. Esa “presión restrictiva” no era otra sino la necesidad. Era ella, por tanto, la que se encargaba de mantener un equilibrio

\footnotetext{
${ }^{247}$ De esta forma, como afirma Karl Polanyi:[...] se tenía un nuevo punto de partida de la ciencia política [...] Towsend eludió la supuestamente inevitable pregunta sobre las fundaciones del gobierno; $\mathrm{y}$ al hacerlo introdujo un nuevo concepto de la ley en los asuntos humanos, el de las leyes de la Naturaleza [...]. El paradigma de las cabras y los perros parecía ofrecer una explicación. La naturaleza biológica del hombre aparecía como el cimiento dado de una sociedad que no era del orden político. Así sucedió que los economistas abandonaron los fundamentos humanísticos de Adam Smith e incorporaron los de Towsend. La ley de la población de Malthus y la ley de la productividad decreciente expuesta por Ricardo hicieron de la fertilidad del hombre y del suelo elementos constitutivos del nuevo reino cuya existencia había sido descubierta. Había surgido la sociedad económica como distinta del estado político (Polanyi, Karl...op.cit. p. 168-170).

${ }^{248}$ Malthus, T.R, Ensayo sobre el principio de la población, FCE, México,1986, p. 52.

${ }^{249}$ Ibid.p. 63.
} 
siempre frágil entre el crecimiento poblacional y el crecimiento de los alimentos. ${ }^{250} \mathrm{El}$ hambre, la enfermedad, la guerra, el infanticidio, la demora del matrimonio, la restricción de la pasión sexual, etc., ${ }^{251}$ debían ser entendidos como dificultades impuestas por la propia naturaleza para mantener el equilibrio de la población.

De esta manera, Malthus desplazaba el análisis de fenómenos hasta entonces interpretados en términos morales para presentarlos como el resultado de leyes naturales. Sin duda podía calificarse como algo terrible que estas dificultades se "hicieran sentir cruelmente” sobre los sectores más vulnerables de la sociedad, sin embargo, el papel de la economía no era el de justificar esos lamentos, sino el de mostrar el funcionamiento de los mecanismos intrínsecos a las leyes de la población.

Por lo mismo, el autor del Ensayo... criticaba a esos “filósofos especulativos” que, amparados en consideraciones morales, hablaban de sistemas “igualitarios”. ${ }^{252}$ Aunque loables en términos morales, estas propuestas eran inconciliables con la tendencia natural del crecimiento poblacional. Según Malthus, si estos proyectos igualitarios llegaran a ponerse en marcha, los recursos de estos sistemas sociales escasearían a largo plazo. Para salir de la situación, afirmaba el inglés, los hombres tendrían que elaborar leyes destinadas a restringir la reproducción:

Supongamos que en un sistema igualitario, a pesar de todos los esfuerzos hechos para procurarse más alimentos, la población se aproxima cada vez más a los límites de lo indispensable para la subsistencia y que todo el mundo se empobrece. En esas circunstancias es evidentemente necesario, para impedir que la sociedad muera, que disminuya el aumento de la población; ¿pero quienes son las personas que han de ejercer la contención así exigida, por arreglo a la cual se han de casar tarde o no se han de casar nunca? No parece que sea una consecuencia necesaria de un sistema igualitario. ${ }^{253}$

En tales circunstancias la legislación humana tendría que actuar injusta y arbitrariamente imponiendo prohibiciones a los individuos. Pero, ¿acaso no era éste un

\footnotetext{
${ }^{250}$ Aquí, Malthus hacía una analogía entre la población y los gérmenes y las plantas cuyo estudio pertenecía, también, al dominio de ciencias naturales: "La necesidad -decía Malthus- esa imperiosa ley de la naturaleza, que todo lo abarca, se encarga de restringir [los gérmenes] manteniéndolos dentro de los límites prescritos. Tanto el reino de las plantas como el de los animales se contraen bajo esta gran ley restrictiva, y el hombre, por mucho que ponga a contribución su razón, tampoco puede escapar de ella” (Ibid.p. 54).

${ }^{251}$ Ibid.

${ }^{252}$ Aquí Malthus se refiere particularmente a Condorcet y a Godwin a quienes explícitamente dedica varios capítulos del Ensayo sobre la población.

${ }^{253}$ Ibid. p. 310.
} 
mecanismo mucho más pernicioso que la propia regulación de la naturaleza?, ¿no era mucho más deseable que los individuos se hicieran cargo de sí mismos y que, en el peor de los casos, la naturaleza se encargara de resolver el excesivo crecimiento de la población?:

Y, sin embargo, si fuera absolutamente necesario, para impedir la miseria más grave, que existiera alguna restricción a la tendencia a casarse en edad temprana cuando los recursos del país, sólo bastan para sostener a un pequeño aumento de la población, ¿puede la imaginación más fértil concebir alguna que sea a un mismo tiempo tan natural, tan justa, tan acorde con las leyes divinas y por las humanas estructuradas por los hombres más instruidos, como el que cada individuo sea responsable del sustento de sus propios hijos? Esto es, ¿que se halle sujeto a los inconvenientes y a las dificultades naturales que se derivan de la satisfacción de sus apetitos, y a ningunas otras? ${ }^{254}$

Como Towsend, Malthus consideraba que cualquier tipo de asistencia gubernamental para enfrentar la desigualdad era menos eficaz y más injusta que los propios mecanismos de la naturaleza. Mecanismos que, además, eran tanto más efectivos cuanto ayudaban a combatir el vicio mediante las virtudes del trabajo:

Es indudable que un estado en el cual la desigualdad de las situaciones ofrece las recompensas naturales a la buena conducta e inspira a todos en general, la esperanza de elevarse y el temor de rebajarse en la sociedad, es el mejor calculador para desarrollar las energías y las facultades del hombre y el más apropiado para el ejercicio y el perfeccionamiento de la virtud humana. ${ }^{255}$

Desde su perspectiva, las leyes de pobres inglesas no sólo contradecían los estímulos de la desigualdad, ${ }^{256}$ también distorsionaban el mecanismo natural de los precios en el mercado. En efecto, cuando los bienes escaseaban en una nación debido al exceso de población, la ayuda económica que se les otorgaba a los trabajadores más pobres terminaba redundando en un aumento en los precios de los bienes:

La transferencia de tres chelines diarios al bolsillo del trabajador -afirmaba Malthus- no aumentaría la carne existente en el país. No basta la que hay en el presente para que todos puedan comer una cantidad moderada de ella. ¿Cuál sería, pues, la consecuencia? La competencia entre los compradores de carne en el mercado haría que subiera con rapidez el

\footnotetext{
254 Ibid. p. 311.

255 Ibid. p. 308.

256 "Por duro que parezca en determinadas circunstancias individuales la pobreza que acude al auxilio de los demás para sostenerse debiera considerarse vergonzosa. El estímulo de bastarse a sí mismo parece ser absolutamente necesario para fomentar la felicidad de la gran masa. De la humanidad y toda tentativa general que se haga para debilitar este estímulo, por muy benévolos que sean sus fines, frustrará siempre sus propios fines”. (Ibid.p.331).
} 
precio de ella [...] y ese artículo no se repartiría entre un mayor número de personas que en la actualidad. Cuando escasea un producto, el que entra en posesión del mismo es el que puede mostrar la patente más válida, esto es el que puede ofrecer más dinero [...] cuando las subsistencias son escasas en proporción al número de los habitantes, importa bien poco que los miembros más pobres posean dos chelines o cinco. En cualquier caso tienen que reducirse a comer los alimentos más ordinarios, y en la menor cantidad. ${ }^{257}$

Así, la ley de hierro de la población era imposible de quebrantar. El exceso de población provocaba escasez; ésta, a su vez, hacía que la ayuda a los trabajadores pobres incrementara la demanda de los bienes, mientras que la oferta no sufría alteraciones. El resultado era previsible: los precios tendían a aumentar. De esta forma, afirmaba Malthus, la mayoría de la sociedad terminaba pagando el costo de una medida que beneficiaba a unos pocos. Era preferible no interferir en el mecanismo de los precios, ya que, al hacerlo, se generaban más problemas de los que se buscaba resolver.

Aunque en el propio Ensayo sobre la población -al igual que en los Principios de economía política-, Malthus advertía sobre circunstancias particulares en las que la protección del Estado ${ }^{258}$ debía justificarse -sobre todo si se trataba de mantener el balance entre el desarrollo agrario y la emergente industria-, ${ }^{259}$ estaba absolutamente convencido de que, en última instancia, aquello que debía orientar el crecimiento poblacional era el equilibrio de las reglas naturales motivado por la presión restrictiva de la necesidad. ${ }^{260}$

La definición de los resortes que hacían funcionar la economía había sufrido una importante transformación. De una regularidad determinada por un orden físico, Malthus pasaba a la definición de unas leyes orientadas por el movimiento de las necesidades. Gracias a este desplazamiento, la objetividad del mercado podía concebirse como el resultado de la libre interacción de los deseos de los individuos. Así, mientras que para Quesnay el laissez faire era una manera de garantizar la reproducción de la tierra y el poder del Estado, para los economistas de principios del siglo XIX los engranajes del mercado parecían estar

\footnotetext{
257 Ibid. p. 321.

258 En el Ensayo, Malthus afirma literalmente: "Para Europa en general, lo más ventajoso es el libre comercio. Pero puede haber países en los que por condiciones particulares no conviene aplicar la regla general” (Ibid.p. 506).

${ }^{260}$ De hecho, en el célebre debate entre Malthus y Ricardo respecto a la abolición de las Corn Law, aquél no se termina defendiendo la limitación a la importación de granos por razones económicas, sino por las circunstancias políticas específicas del momento.
} 
plenamente vinculados con la capacidad de garantizar el desarrollo libre y espontáneo de los “deseos” y las “necesidades” individuales.

\subsection{La propiedad privada y el mercado en el dispositivo liberal}

Aunque las doctrinas de autores como Malthus y Jean Baptiste Say pueden tener serias diferencias en el marco de la disciplina económica, una mirada genealógica nos muestra el horizonte del saber que ambos comparten. En su Tratado de Economía Política Say asegura, como Malthus, que los ciclos de la producción y el consumo sólo pueden ser coordinados por un mecanismo peculiar establecido gracias a la naturaleza de las necesidades: ${ }^{261}$

La naturaleza de las necesidades de la sociedad (c/n) -afirma- determina en cada época, y según las circunstancias, el pedido más o menos frecuente de tales o tales productos: de donde resulta que en estas especies de producción son algo mejor pagado los servicios productivos que en los demás ramos, es decir, que las ganancias que se sacan del uso de la tierra, de los capitales y del trabajo, son algo mayores en aquellas. Estas ganancias atraen hacia estos ramos a los productores, y así es que la naturaleza de los productos se acomoda siempre naturalmente a las necesidades de la sociedad. ${ }^{262}$

$\mathrm{Al}$ apelar a la naturaleza de las necesidades para definir los equilibrios de la oferta y la demanda, Say se situaba en el espacio del saber abierto por Malthus. En los años posteriores, este argumento dio pie a múltiples controversias entre los economistas: para algunos, Say habría descubierto una suerte de axioma económico según el cual "toda oferta crea su propia demanda”; para otros, en cambio, se limitaba a promover los intereses de la clase burguesa.

En realidad, la intervención de Jean Baptiste Say se encontraba profundamente marcada por la experiencia política de su tiempo. Así, cuando el francés sostuvo que las “necesidades” de una sociedad son la única guía que define adecuadamente la inversión en los ramos de la producción, intentaba mostrar la falta de "racionalidad” de las restricciones al comercio de los bienes de primera necesidad impuestas por el ala democrática de la Revolución francesa durante el periodo jacobino, ${ }^{263}$ así como las políticas de intervención estatal implementadas por 'el bonapartismo ${ }^{264}$

\footnotetext{
261 Véase: Infra. Capítulo: “Fraternidad y democracia en la primera República”.

262 Say, Jean Baptiste, Tratado de Economía Política, FCE, México, 2001.

263 Véase: Infra: "Fraternidad y derecho al trabajo".

${ }^{264}$ Cfr. Hobswan, Eric, Los ecos de la Marsellesa, Crítica, Barcelona 2003,p.31.
} 
A los ojos del economista francés, éstas medidas transgredían el “orden natural de las cosas”, pues, al dirigir una parte de los medios de producción a un sector definido bajo criterios políticos, se violaban las exigencias de esa nueva entidad objetiva apresada mediante el concepto de necesidades naturales:

Cuando el gobierno se atraviesa en medio de este orden natural de las cosas (c/n), y dice: El producto que se quiere crear, el que da mayores ganancias, y por consiguiente el que se pide con preferencia, no es el que conviene, y es necesario dedicarse a este o a aquel; dirige evidentemente una parte de los medios de producción hacia un ramo de industria cuya necesidad es menos urgente, a expensas de otro que hace mucha más falta. ${ }^{265}$

Ahora bien, la emergencia del juego de las necesidades individuales -sobre el que ahora se sostenía la objetividad del análisis económico- dependía de una condición jurídica previa, a saber: el derecho de propiedad. De hecho, afrimaba Say, sólo cuando la propiedad era garantizada plenamente, las necesidades de los individuos podían florecer libre y espontáneamente conformando un conjunto de tendencias ajenas a cualquier condicionamiento artificial.

No obstante, el acto jurídico consistente en asegurar la propiedad no era interpretado como una garantía política inseparable del desarrollo económico, sino como una exigencia de la propia naturaleza del mercado. De ahí que, como afirmaba Say, para los economistas el problema no debía consistir en establecer los fundamentos morales o jurídicos de la propiedad sino en mostrar su necesidad para el funcionamiento de ese sistema natural de necesidades recíprocas:

El filósofo especulativo -señalaba el francés- puede ocuparse en investigar los verdaderos fundamentos del derecho de propiedad; el jurisconsulto puede establecer las reglas que dirigen la transmisión de las cosas poseídas; la ciencia política puede mostrar cuáles son las más seguras garantías de este derecho. Pero la Economía política considera solamente la propiedad como el estímulo más poderoso para la multiplicación de las riquezas (c/n), y así tratará muy poco de lo que la constituye y afianza, con tal que esté asegurada. ${ }^{266}$

Una vez que la propiedad era asegurada, la industria podía obtener su "recompensa natural”. ${ }^{267}$ Para Say, esta recompensa no era otra sino el incremento de la riqueza, una consecuencia lógica de la acción racional de los propietarios. Según el francés, si los

\footnotetext{
265 Say Jean Baptiste, Tratado...op.cit.

${ }^{266}$ Ibid.p.116.

${ }^{267}$ Ibid.p.133.
} 
propietarios individuales eran los únicos capaces de decidir cuánto gastar y cuánto conservar, cuándo invertir y cuándo no hacerlo, ${ }^{268}$ en función de esa guía natural establecida por sus necesidades, la industria no podía sino crecer en coordinación con las demandas de la población. Así, la garantía de la propiedad representaba, al mismo tiempo, la garantía de la libertad de elección de los individuos en el mercado. ${ }^{269}$

Sin embargo, era por ese mismo razonamiento que Say concluía que el derecho de propiedad, en tanto exigencia natural del mercado, debía ser entendido como la capacidad de “usar e incluso de abusar” de los bienes materiales sin la intromisión de ningún agente externo. Así, casi cualquier regulación social en el ámbito de la propiedad debía ser entendida como una violación a los derechos naturales de los individuos propietarios:

No hay propiedad segura donde quiera que un déspota puede apoderarse de los bienes de sus súbditos sin que estos lo consientan: ni está más segura la propiedad, cuando el consentimiento es puramente ilusorio. Observaré que se puede violar el derecho de propiedad, no sólo apoderándose de los productos que saca el hombre de sus tierras, de sus capitales o de su industria, sino también sujetándole en el libre uso de estos mismos medios de producción; porque el derecho de propiedad, según le definen los jurisconsultos, es el derecho de usar, y aun de abusar(c/n). Por consiguiente, es violar la propiedad territorial prohibirle a un propietario lo que debe sembrar o plantar; prohibirle tal cultivo u tal modo de cultivar. Es violar la propiedad del capitalista prohibirle tal o tal uso de sus capitales; como cuando no se le permite almacenar trigo u cuando se le obliga a llevar su plata labrada a la casa de moneda, o bien cuando se le impide que edifique en su terreno, o se le prescribe el modo con que ha de edificar. Es violar la propiedad del capitalista, cuando después de tener capitales empleados en una industria, cualquiera que sea, se prohíbe este género de industria, o se la recarga con derechos tan numerosos que equivalen a una prohibición. ${ }^{270}$

268 Say se preguntaba: «Qui ne sait qứen général nul ne connaît mieux que le propriétaire le parti qu'on peut tirer de sa chose, et que nul ne met plus de diligence à la conserver? », Say, Jean Baptiste, Collection de Principaux Economistes, Osnabrück, s/l,1966, p. 133.

${ }^{269}$ En el Ensayo sobre la población, Malthus había hecho lo propio mostrando que la institución de la propiedad era una condición indispensable para el “estimulo de las riquezas”. Como vimos, el inglés hacia frente a aquellas teorías que defendían la distribución común de los bienes porque, a largo plazo, provocaría la escasez de recursos y obligaría a los gobernantes a instaurar diferencias arbitrarias entre la población. En cambio, Malthus intentaba mostrar que la existencia de desigualdades obligaba a satisfacer las necesidades de los individuos mediante el trabajo y el comercio. Pues bien, según este economista, esa desigualdad no era otra cosa que la consecuencia de la "institución de la propiedad". En efecto, después de criticar los sistemas igualitarios Malthus concluía que, tanto la institución del matrimonio como la propiedad privada, eran las dos leyes naturales de la sociedad que, mediante la instauración de la desigualdad, aseguraban el único equilibrio posible de la población: "Una vez establecidas estas dos leyes naturales de la sociedad: el mantenimiento de la propiedad y la institución del matrimonio, la desigualdad de las condiciones humanas debía seguir forzosamente. [...] Nosotros ya hemos visto los efectos deplorables que resultarían de la igualdad, si cada uno tuviera el derecho de reclamar su parte de productos de la tierra. Los miembros de una familia se volverían muy numerosos para la parcela que les ha sido atribuido originalmente, no podrían reclamar más como una deuda de justicia una parte del excedente producido por los otros. Así, las leyes inevitables de la naturaleza humana condenarían a ciertos individuos a vivir en la necesidad”. Malthus,...op.cit.

270 Say..op.cit. 
De esta forma, una definición extremadamente peculiar del derecho de propiedad se presentaba como el resultado de la naturaleza de las cosas. No obstante, la definición del derecho de propiedad como la ausencia de cualquier restricción para el uso de los bienes destinados al mercado tenía muy poco de natural y mucho de artificial. Lejos de reflejar el desarrollo espontáneo de los procesos de socialización, representaba un punto de ruptura respecto al pasado reciente, pero también respecto a la tradición del derecho natural que había establecido los cimientos intelectuales de la Revolución francesa.

Como ha analizado William H. Sewell, al menos cuatro tipos de propiedad fueron reconocidos jurídicamente durante el Antiguo Régimen, a saber: la propiedad privada absoluta, la propiedad privada regulada para satisfacer el bien público, la propiedad de los cargos públicos $\mathrm{y}$, finalmente, un conjunto de derechos que eran considerados semipropiedades, como las prerrogativas y las distinciones hereditarias. ${ }^{271}$

La noche del 4 de agosto de 1789 se redefinió el derecho de propiedad en Francia reduciendo su significado a "la posesión de cosas por individuos", esta transformación se formalizó en la primera versión de la Declaración de los Derechos del Hombre y del Ciudadano. En ella, la propiedad (recién limitada a su carácter de propiedad privada absoluta) se incorporaba al catálogo de derechos naturales del hombre junto a la libertad, la seguridad y la resistencia a la opresión. ${ }^{272}$

No es de sorprender que después de la Revolución de 1789 tanto la propiedad de los cargos públicos, como las prerrogativas fueran eliminadas, ya que contradecían la aspiración ilustrada de una verdadera igualdad jurídica. Sin embargo, la eliminación de la propiedad privada que tenía como restricción la satisfacción del bien público no era una consecuencia inmediata de la filosofía del derecho natural en la que se había fraguado el crisol de la Revolución. 273

\footnotetext{
${ }^{271}$ Cfr, Sewell... op. cit. p. 167-168.

272 A lo largo de toda la Revolución Francesa tendrá lugar una disputa sobre la manera en que debía comprenderse el derecho de propiedad. El IX de Termidor representa la victoria de los sectores que optaban por reducir el derecho de propiedad al de "posesión de cosas por individuos". Así, en la Declaración de los Derechos del Hombre y del Ciudadano de 1795, la propiedad será limitada al carácter de propiedad privada de bienes materiales. Al respecto, véase: Gauthier, Florence, Triomphe..., op.cit.p.59ss.

${ }^{273}$ Ibid.p. 60.
} 
En realidad, de Locke a Rousseau, pasando por Mably y Montesquieu, la tradición del derecho natural había supeditado el derecho de propiedad a distintas formas de regulación social. Sea, como en el caso de Locke, en el que todo ciudadano se encuentra obligado a supeditar la propiedad individual a la legislación social una vez que se adscribía al Gobierno civil; sea, como en el caso de Montesquieu, en el que la crítica al despotismo económico viene aparejada de la defensa de una economía sometida a las necesidades sociales; ${ }^{274}$ sea, como en el caso de Rousseau, donde la apropiación privada se presenta como la fuente de todas las desigualdades hasta que es reparada por un acuerdo jurídico fundado en la voluntad colectiva; en todos los casos, la propiedad privada estaba circunscrita a los límites impuestos por una representación de la voluntad del pueblo, una representación encarnada en un poder legislativo necesariamente orientado al bienestar común.

Con ello, desde luego, no se trata de negar las diferencias existentes en el interior de la tradición del derecho natural, ni de reivindicarla a-críticamente, sino de mostrar que la forma argumentativa en la que operaba impedía que el interés general fuera supeditado a los intereses particulares. En efecto, dado que la resolución de los conflictos sociales era pensada en el marco de una regulación jurídica sometida a un acuerdo colectivo, los intereses particulares debían responder a las condiciones de ese acuerdo.

Sólo en la segunda mitad del siglo XVIII ${ }^{275}$ comenzó a abrirse paso la idea de que la libertad irrestricta en el uso de las propiedades individuales era capaz de producir el mayor beneficio social posible. ${ }^{276}$ Sin embargo, las consecuencias prácticas de esta seductora hipótesis teórica eran bien distintas. ${ }^{277}$ En Francia, el desarrollo de las grandes granjas para

${ }^{274}$ En El espíritu de las leyes, Montesquieu critica las formas de concentración ilimitada de la propiedad privada, mostrando la obligación del Estado respecto a los ciudadanos más pobres: “Quelques aumônes que l'on fait à une homme nue dans les rues ne remplissent pas les obligations de l’État, qui doit á tous les citoyens une subsistance assurée, la nourriture, un vêtement convenable et un genre de vie qui ne soit pas contraire à la santé» (Montesquieu, De l'esprit des lois, La Pléiade, Paris, 1951,p. 712).

${ }^{275}$ Cfr, Davidson, Neil, Transformar el mundo, Ediciones Pasado y Presente, Barcelona, 2013, p. 114.

${ }^{276}$ En 1790, apenas un año después de que la Revolución hubiera iniciado, Condorcet publicó un resumen de La riqueza de las Naciones en francés (Davidson,... op. cit. p. 115). Aunque los estudiosos de Smith han mostrado que el escocés no era un dogmático defensor del mercado que renunciaba por principio a cualquier intervención del Estado, también es cierto que los lectores de finales del siglo XVIII y XIX quedaron bastante impactados por la idea, insoslayable en el libro de Smith, de que la acción individual es mucho más eficaz que la coordinación colectiva para obtener el bienestar público. Desde luego, el contexto de la Francia dieciochesca no era el que Smith había imaginado para una situación semejante, además de ello la parcialidad con la que fue retomado su texto principal tuvo mucho que ver con que posteriormente se le identificara con el liberalismo económico más dogmático.

${ }^{277}$ Los pocos intentos de implementar esta visión de la sociedad han tenido resultados desastrosos, mismos que, en general, han venido acompañados de amplias resistencias sociales. En Francia, tanto los intentos de Turgot 
el monocultivo cerealero favoreció la expropiación del campesinado, ${ }^{278}$ con lo cual la liberación de las restricciones a la propiedad se presentó como el escenario perfecto para el ascenso de los grandes propietarios y la subordinación de los campesinos desposeídos.

Además, en el contexto francés, la redefinición de la propiedad como propiedad privada ilimitada le abría de lleno el terreno a prácticas de acaparamiento y especulación en el mercado de los bienes de subsistencia, tal como efectivamente ocurrió en 1792 durante la llamada Guerra de los cereales. En esas circunstancias, la libertad irrestricta en el manejo de las grandes propiedades no sólo no garantizaba el bienestar de toda la sociedad, sino que amenazaba la subsistencia misma de los trabajadores del campo y su independencia respecto a los grandes propietarios. ${ }^{279}$

La defensa de las regulaciones sociales al comercio de los bienes de subsistencia por parte del jacobinismo radical sólo puede entenderse en ese contexto; sin embargo, desde la perspectiva de Say, eran precisamente estas medidas las que amenazaban los fundamentos mismos del derecho de propiedad. Una vez que la propiedad irrestricta de los bienes materiales había sido identificada con las exigencias naturales del mercado, la reivindicación del derecho de propiedad no parecía obedecer a otra cosa sino a la objetividad más incuestionable.

A pesar de sus semejanzas superficiales, la concepción de la propiedad de Say se hallaba en unas coordenadas muy diferentes a las de John Locke. Mientras en el Segundo Ensayo sobre el gobierno civil el inglés afirmaba que:

en la década de 1770, como los del ala girondina de la Revolución, destinados a imponer la libertad total del comercio terminaron en sendas revueltas populares. Sólo el liberalismo posterior fue capaz de introducir el principio del libre comercio en un dispositivo de ideas y prácticas complejo que, sin embargo, nunca pudo ser implementado de una manera fiel a cómo había sido racionalizado. Por lo mismo, y a diferencia de Florence Gauthier, en este trabajo no asemejo inmediatamente el principio del libre comercio, surgido en primer lugar entre los fisiócratas y después retomado por Turgot, con el dispositivo liberal desarrollado con muchas dificultades medio siglo después.

${ }^{278}$ Cfr. Gauthier, Florence, "Soberanía, república, democracia y derechos son bienes comunes de todos los pueblos libres”. Consultado el 29/07/2015 en: http://www.sinpermiso.info/textos/soberana-repblicademocracia-y-derechos-son-bienes-comunes-de-todos-los-pueblos-libres

${ }^{279}$ La idea de que bastaba mayor libertad individual para enfrentar los problemas sociales fue igualmente utilizada con el fin de justificar la famosa ley de Le Chapelier, la cual prohibía las corporaciones de trabajadores de oficio y desarmaba cualquier forma de protección ante sus patrones (Soboul, Albert, Revolución Francesa, Tecnos, Madrid, 1983, p. 125). Ciertamente, las relaciones que tenían lugar en el interior del mundo corporativo distaban mucho de garantizar la libertad y la igualdad a la que aspiraba la Revolución, sin embargo, la eliminación de las corporaciones volvía a los trabajadores aún más dependientes de los patrones y menos capaces de organizarse contra las injusticias. Todo ello en una época donde, como ha analizado con detalle Robert Castel, la única protección de los trabajadores era su adscripción gremial (Castel, Robert, El ascenso de la incertidumbre, Fondo de Cultura Económica, México, 2010, p. 61-64). 
[...] for it would be a direct contradiction, for any one to enter into society with others for the securing and regulating of property; and yet to suppose his land, whose property is to be regulated by the laws of the society, should be exempt from the jurisdiction pf that government, to which he himself, the proprietor of the land, is a subject. By the same act therefore, whereby any one unites his persons, which was before free, to any common-wealth, by the same he unites his possessions, which were before free, to it also; and they become, both of them, person and possession, subject to the government and dominion of that common-wealth, as long as it hath a being. ${ }^{280}$

Por su parte, Jean Baptiste Say sostenía que no sólo se viola el derecho de propiedad “apoderándose de los productos que saca el hombre de sus tierras, de sus capitales o de su industria”:

[...] sino también sujetándole en el libre uso de estos mismos medios de producción; porque el derecho de propiedad [...] es el derecho de usar, y aun de abusar. ${ }^{281}$

Sin duda, entre estas dos afirmaciones había una distancia considerable. Como vimos, en el espacio del saber en el que Locke se encontraba aún no se levantaba el muro que dividía el ámbito de lo público de los mecanismos anónimos del mercado, sólo después de que el derecho de propiedad fuera problematizado como una condición necesaria para el funcionamiento de un mercado autorregulado, las más diversas formas de gestión social de la propiedad -con las cuales había convivido la humanidad desde hace siglos- comenzaron a ser interpretadas como intervenciones ilegítimas del gobierno sobre una esfera que le era “naturalmente” ajena.

Tan sólo a finales del siglo XVIII, en las entrañas del dispositivo liberal emergente, una formulación semejante comenzaba a tener sentido. Como ocurría con los fisiócratas, la esfera de la circulación de bienes daba paso a una realidad que operaba en el registro de la “verdad”, sin embargo, a diferencia de aquellos, su coherencia interna no dependía de un orden físico, sino de un conjunto de reglas emanadas de la libre interacción de los individuos una vez que la propiedad privada ilimitada era garantizada. Así, las regulaciones sociales en materia económica eran interpretadas, a la vez, como una intervención en los mecanismos

\footnotetext{
280 Véase: Infra, p.86.

${ }^{281}$ Véase: Infra.p.121.
} 
naturales del mercado y como una violación tanto de los derechos de propiedad, como de la propia libertad de los individuos.

\subsection{Pobres laboriosos}

En una carta escrita a William Smith en 1795, el historiador irlandés, Edmund Burke, escribía lo siguiente:

¿Qué es el Jacobinismo? [...] los Jacobinos han decidido destruir todas las estructuras de las viejas sociedades del mundo para regenerarlas a su manera. Para conseguir un ejército para ese fin, en todas partes reclutan a los pobres, mostrándoles como cebo, los despojos de los ricos. ${ }^{282}$

Desde su perspectiva, el éxito de los jacobinos estaba vinculado a la divulgación de una idea falsa. Esta idea falsa consistía en presentar la pobreza como el resultado de un acto de despojo ejercido por unos cuantos privilegiados sobre la mayoría de los habitantes de una comunidad. Sin embargo, al igual que Towsend y Malthus, Burke consideraba que la pobreza no era otra cosa sino una consecuencia necesaria de la escasez de recursos:

Los trabajadores sólo son pobres porque son numerosos. Las cifras implican pobreza, dentro de su naturaleza. En una distribución equitativa, una multitud nunca recibiría mucho. Aquella clase de dependientes que denominamos ricos son tan escasos que si se les elimina a todos y se distribuyera lo que ellos consumen en un año, no alcanzaría para una ración de pan y queso para todos los que trabajan. ${ }^{283}$

Por ello, en sus Pensamientos y detalles sobre la escasez, Burke se oponía a quienes, para solucionar el problema de la pobreza, intentaban promover una rebelón de los pobres. Esta estrategia, pensaba el irlandés, no sólo resultaba ilegitima, sino que iba en contra de los propios intereses de los más desfavorecidos:

Cuando los pobres se rebelan para destruir a los ricos actúan en forma tan desacertada para sus propios intereses como si incendiaran molinos y botaran el maíz al agua para abaratar el pan. ${ }^{284}$

\footnotetext{
${ }^{282}$ Fontaine, Arturo, “Selección de escritos de Edmund Burke”, en: Estudios Públicos, N9, Chile, 1993.

${ }^{283}$ Ibid.

${ }^{284}$ Ibid.
} 
Los ejemplos elegidos por Burke no eran arbitrarios. Al incendiar los molinos o al botar el maíz al agua, ¿qué intentaban hacer los pobres sino controlar el precio de los productos? ¿Y, acaso, esta acción no resultaba tanto más imprudente cuanto el mercado era el único capaz de decidir los precios de los mismo? En efecto, a pesar de su conservadurismo político, Burke compartía con los economistas de la época el asombro ante el aparente equilibrio natural del consumo y la producción:

El equilibrio entre el consumo y la producción -decía Burke- da lugar al precio. El mercado decide ese precio, y es el único que puede hacerlo. El mercado es el encuentro y acuerdo entre el consumidor y el productor, cuando cada uno de ellos descubre las carencias del otro. Nadie, en mi opinión, ha observado reflexivamente el mercado sin sentirse asombrado por la verdad, la corrección, la celeridad, y la equidad general con que se establece el equilibrio entre las carencias. $^{285}$

Así, como lo había hecho Malthus y como posteriormente lo haría Say, Burke apelaba al equilibrio natural del mercado para rechazar cualquier tipo de regulación social por parte del gobierno. Cuando, en momentos de escasez, el gobierno intervenía para evitar el aumento de los precios, la demanda tendía a aumentar por encima de la oferta poniendo en riesgo todo el proceso productivo:

Quienes desean la destrucción de ese equilibrio y preferirían una regulación arbitraria por decreto, sin que la escasez de producción se vea compensada por un aumento de precio, dejan caer literalmente su hacha sobre las raíces de la propia producción. ${ }^{286}$

De este razonamiento, Burke sacaba una conclusión absolutamente relevante: si toda regulación en el ámbito del mercado ponía en riesgo el equilibrio de la producción, la intervención del gobierno para ayudar a la manutención de los pobres también debía ser interpretada como una amenaza para ese equilibrio. Ahora bien, aunque esta afirmación era presentada por Burke como una consecuencia de las exigencias naturales del mercado, sólo era formulable bajo una condición previa, a saber: que el trabajo fuera concebido como una mercancía:

\footnotetext{
${ }^{285}$ Citado en Davidson, Neil...op.cit. p. 128.

${ }^{286}$ Citado en: Fontaine...op.cit..
} 
El trabajo -afirmaba el irlandés- es una mercancía como cualquier otra, que sube y baja de acuerdo a la demanda. Esto está en la naturaleza misma de las cosas, pero esa naturaleza misma se ha hecho cargo de sus necesidades. ${ }^{287}$

Sólo de esta manera, la crítica hacia la intervención del gobierno en el mercado de bienes ${ }^{288}$ podía hacerse extensiva a las medidas de asistencia destinadas a los pobres. Si los intentos de aumentar o disminuir los precios de las mercancías a través de regulaciones artificiales interferían en el libre equilibrio de la producción y el consumo, las diversas formas de asistencia a los más necesitados -estipuladas por las leyes de pobres- impedían la estabilidad en los precios de esa mercancía particular llamada trabajo.

Esto era así porque los aportes del Estado destinados a la subsistencia de los más desfavorecidos los llevaba a no aceptar los ínfimos precios impuestos en el mercado de trabajo. En esta circunstancia, pensaba Burke, el equilibrio natural entre la producción y el consumo se veía constantemente amenazado. Sin embargo, este no era el único problema. El irlandés consideraba que, al mismo tiempo que la asistencia distorsionaba el equilibrio del mercado, amenazaba el sagrado principio de la propiedad. Así, además de ser un riesgo económico, la intervención del Estado era presentada como una verdadera amenaza política.

Y es que, para garantizar que el precio del trabajo permitiera solventar la subsistencia de los hombres, sólo había dos posibilidades: obligar a los compradores a pagar un precio mayor al asignado por el mercado para comprar esa mercancía llamada trabajo; o instaurar medidas de asistencia que, en última instancia, eran costeadas por un aumento en los impuestos de los compradores. En ambos casos, se trataba de transferir injustamente la propiedad que unos habían adquirido legítimamente en el mercado para mantener al resto de los individuos. Así, desde la perspectiva de Burke, estas medidas violaban el derecho que todos los hombres tenían a hacer uso de su propiedad de manera libre, sin interferencia de ningún tercero.

De ahí que la posición de Burke fuera radical en esta materia. A sus ojos, no importaba que el precio del trabajo asignado por el mercado fuera insuficiente para garantizar la

\footnotetext{
287 Ibid.

${ }^{288}$ En sus "Pensamientos y Detalles sobre la Escasez”, el oriundo de Irlanda aseguraba que la interferencia del gobierno en el comercio de alimentos era sumamente peligrosa porque aumentaba los precios del mercado: “De todas las cosas -decía Burke- una intervención indiscreta en el comercio de alimentos, es muy peligrosa, y peor en la época en la que los hombres están más dispuestos a esto; esto es, en una época de escasez" (Citado en Himmelfare...op.cit. pp. 83-84).
} 
subsistencia de los seres humanos, en tanto mercancías, ellos dependían de ese equilibrio de las carencias establecido por la coordinación de la producción y el consumo. El riesgo que se corría al intentar determinar artificialmente los precios del mercado, incluido el del trabajo, era tan grande que resultaba preferible no intervenir en sus mecanismos, incluso si esto significaba condenar a grandes sectores de la población a vivir en la carencia:

Si un hombre no alcanza a vivir y mantener su familia con el producto de su trabajo, ¿no debería la autoridad intervenir para alzarlo? [...] Partamos, como ya dije, de la premisa de que el trabajo es una mercancía, un artículo de comercio. Si estamos en lo cierto, el trabajo deberá estar sometido a las leyes y principios del comercio y no a otros que pueden ser ajenos a aquellas leyes y principios. Cuando una mercancía es llevada al mercado, su precio lo fija la necesidad del comprador y no la del vendedor. La extrema necesidad del vendedor tiende más bien (por la naturaleza de las cosas que no podemos controlar) a resultados totalmente opuestos. Si esa mercancía abunda en el mercado, bajará su precio. Si escasea, su precio subirá. Desde este punto de vista, la subsistencia del hombre que ofrece su trabajo no es el problema. El problema es, ¿¿cuál es el valor de su trabajo para el comprador? Pero si interviene la autoridad y obliga al comprador a pagar un precio, ¿̇a qué equivaldría? [...] ¿no equivaldría a dividir arbitrariamente su propiedad entre todos? ${ }^{289}$

Este modo de plantear las cosas suponía una inversión total de la alternativa planteada por el pensamiento jacobino. En efecto, mientras que para los revolucionarios radicales el trabajador era, ante todo, un ser humano que debía tener garantizada su subsistencia para poder ejercer sus derechos, para Burke el trabajo era primordialmente una mercancía que debía sujetarse a la asignación de los precios impuesta por el equilibrio de las necesidades: una nueva forma de problematizar el trabajo comenzaba a abrirse las puertas en el pensamiento europeo.

Ahora bien, únicamente cuando el trabajo comenzó a ser problematizado como una mercancía, aquello que en la lógica del Antiguo Régimen era una obligación paternalista del Estado y en la lógica del republicanismo radical se concebía como un derecho (el derecho a la existencia), terminó por transformarse, al mismo tiempo, en una amenaza económica contra la racionalidad natural del mercado y en una violación política del derecho de propiedad.

${ }^{289}$ Ibid. 
Ante lo cual, Burke concluía que sólo la “jurisprudencia de la piedad” podía hacerse cargo de la pobreza. ${ }^{290}$ No obstante, eso que Burke denominaba como "jurisprudencia de la piedad” no tenía competencia legítima sobre todos los desfavorecidos, sino que debía limitarse a aquellos que no podían valerse por sí mismos (not-able bodies), mientras que aquellos que mantenían intacta su capacidad de trabajar se veían obligados a buscar a toda costa la recompensa de su esfuerzo en el mercado.

El razonamiento del irlandés era el siguiente: quienes tenían alguna incapacidad para trabajar podían aspirar legítimamente a alguna forma de asistencia porque carecían de todo producto para vender en el mercado. No obstante, quienes mantenían intacta dicha capacidad se convertían inmediatamente en propietarios de una mercancía susceptible de ser intercambiada en el mercado. ${ }^{291}$ Por lo mismo, resultaba enteramente ilegítimo afirmar que quienes podían ejercer sus labores cotidianamente pertenecían a la misma categoría que aquellos que estaban impedidos para hacerlo. Unos eran auténticos desposeídos, mientras que los otros eran propietarios de una mercancía tan valiosa como las otras: su propio trabajo.

Una cosa, por tanto, era la verdadera pobreza y otra muy distinta la falta de disposición para insertarse en los mecanismos del mercado. De ahí que, para Burke, la expresión “pobres laboriosos” fuera un auténtico sinsentido:

Nada podría ser más bajo y más vil que ese lenguaje político que habla de "los pobres laboriosos" [...] Una necesidad no se alivia por otra necesidad. Sólo hay que recomendar paciencia, trabajo, sobriedad, frugalidad, y religión. Todo lo demás es engaño. ${ }^{292}$

Casi cuatro décadas después de que Edmund Burke escribiera sus Pensamientos y detalles sobre la escasez, los encargados del Informe para la Reforma de las Leyes de Pobres, establecieron una distinción semejante entre trabajadores pobres e indigentes. En el prefacio de dicho informe se afirmaba que cualquier reforma a la legislación isabelina debía iniciar

\footnotetext{
${ }^{290}$ Más adelante regresaremos sobre este punto -crucial en el dispositivo liberal-, ahora, sin embargo, nos interesa centrarnos en las consecuencias que el irlandés obtenía de esta afirmación

${ }^{291}$ De hecho, Burke distinguía tajantemente entre "trabajadores” y “pobres”, Desde su perspectiva, no se podía ser, al mismo tiempo, pobre y trabajador, la amalgama en la que años después Marx descubriría la consistencia misma del capitalismo industrial no existía para Burke. En su vocabulario el concepto "pobres laboriosos" era un verdadero oxímoron.

292 Ibid.
} 
por distinguir entre estos dos tipos de individuos para determinar quiénes estaban dentro del alcance de legislación y quiénes debían estar sujetos a las exigencias del mercado. ${ }^{293}$

Publicada después de amplios debates en 1834, la Nueva Ley de Pobres limitaba los apoyos gubernamentales a los “indigentes”. Sin embargo, esta categoría no era del todo transparente. Por tanto, se volvía necesario hacer una distinción aún más precisa entre los indigentes impotentes -o incapaces de trabajar (not able bodies)- y los indigentes sanos. De ellos, sólo los primeros podían acceder legítimamente a la asistencia pública, si los indigentes sanos aspiraban a algún tipo de alivio (relief) debían inscribirse en los reformatorios o workhouses. Aunque, en Inglaterra las casas de trabajo eran herederas de una larga historia, la Nueva Ley de Pobres les otorgaba un papel singular que sólo era posible en un tiempo en el que el trabajo comenzaba a ser pensado en unas nuevas coordenadas.

Establecidas en 1670 mediante un decreto gubernamental, las work-houses eran, al mismo tiempo, instancias para enfrentar la miseria e instrumentos del Estado para mantener el orden público. ${ }^{294}$ Esa doble función las llevaba a albergar, al mismo tiempo, a una masa de individuos aparentemente heterogénea: pequeños delincuentes, vagabundos, enfermos, miserables, pobres, locos, etc. Dado que las work-houses eran financiadas a través de un impuesto estatal y a través de los aportes de la caridad, no perseguían fines de lucro, más bien aspiraban a mantener el orden público y a moralizar a los individuos mediante las virtudes del trabajo. Como en el imaginario de la época el ocio se emparentaba con el vicio, el trabajo debía ayudar a reincorporar a esta masa de seres inmorales e improductivos al orden social. Así, si en alguna medida las work-houses tenían un objetivo económico éste se encontraba estrechamente vinculado a un proyecto de moralización y mantenimiento del orden público.

Ciertamente estos elementos no desaparecerán del todo hacia el siglo XIX, sin embargo, la Nueva Ley de Pobres le asignará una nueva finalidad a estas instituciones. Como

\footnotetext{
${ }^{293}$ Citado en: Himmelfare,...op.cit.p.188.

${ }^{294}$ Aunque desde 1575 un acta prescribía la construcción de houses of correction destinadas al alivio de los pobres, su desarrollo será incierto. Sólo un siglo después las work-houses se instalan con éxito, primero en Inglaterra y después en buena parte de Europa. Al respecto, Foucault hace un interesante análisis en el que muestra como las instituciones del encierro de la "época clásica" daban cuenta de un cambio de "sensibilidad social”. La pobreza, por tanto, dejaba de significar una prueba que apelaba a la virtud de quienes llevaban a cabo actos de caridad, para convertirse en una muestra del desorden de una sociedad y de su culpabilidad. Entonces el encierro adquiere una nueva significación. El trabajo es, al mismo tiempo, una forma de combatir el ocio y de enfrentar el vicio, de moralizar al hombre. Cfr, Foucault, Michel, Historia de la locura en la época clásica I, FCE, México, 2006, p.86ss.
} 
hemos visto, la legislación estipulaba que la única forma en que los individuos “aptos para el trabajo” (able-bodies) podían recibir una ayuda para su manutención era incorporándose a las casas de trabajo, sin embargo, la Nueva Ley de Pobres añadía dos elementos: en primer lugar afirmaba que las condiciones de vida en estas instituciones debían ser "menos aceptables” que aquellas que caracterizaban a "los trabajadores más desfavorecidos”; y, en segundo lugar, señalaba que se debía exigir una cantidad de trabajo mayor al que se les exigía a los asalariados. De esta forma, las casas de trabajo eran pensadas menos como un instrumento de exclusión social y más como incentivo para incorporar a los indigentes al mercado laboral. En efecto, si las condiciones de vida en estas instituciones eran peores que aquellas que podía tener el trabajador más desfavorecido, a los indigentes sanos debía resultarles preferible la insertarse en el mercado. Así, aunque las work-houses implicaban la intervención activa del gobierno, ésta sólo tenía sentido en cuanto promovía una distinción más clara entre quienes, por su incapacidad, debían sestar sujetos a la asistencia y quienes, por el contrario, debían someterse a la regulación del mercado. En realidad, el liberalismo decimonónico nunca se planteó como ideal abolir el Estado en favor del mercado, sino hacer funcionar a aquél en unas coordenadas novedosas.

Aunque es verdad que los partidarios del laissez faire más radicales, entre los que entonces se encontraba Malthus y los malthusianos, exigían la abolición total de la Leyes de Pobres Isabelinas, ${ }^{295}$ no deja de ser cierto $^{296}$ que la división en la que se sostenía toda la

\footnotetext{
295 Entre otros motivos, la renuencia de los sectores agrícolas y la oposición de los gestores del sistema de asistencia evitaron la abolición total de las Leyes de Pobres.

${ }^{296}$ Uno de los redactores más influyentes del Informe sobre las leyes de pobres, mismo que dio lugar a la Reforma, fue Nassau William Senior. Como economista Senior consideraba que el trabajo era una mercancía más en el engranaje de un mercado autorregulado. Desde su perspectiva, el crecimiento económico dependía del aumento de la renta del capital, así, al interferir con el desarrollo natural del proceso de acumulación, la instauración de impuestos destinados a salvaguardar la existencia de los pobres amenazaba el crecimiento. Este argumento no era nada novedoso, desde los famosos Principios de Economía Política y Tribiutación, David Ricardo lo había desarrollado apelando al "principio evidente” de la libre concurrencia y al "orden natural” de la sociedad: "La tendencia clara y directa de las leyes de pobres está en oposición directa con estos principios evidentes (principios de la libre concurrencia del mercado) [...]mientras estén en vigor, está en el orden natural de las cosas que los fondos destinados al sostenimiento de los pobres vayan aumentando progresivamente hasta que hayan absorbido todas las rentas netas del país [...] La tendencia perniciosa de estas leyes no es ya un misterio, desde que ha sido hábilmente desarrollada por la hábil pluma de Mr. Malthus; y todos los amigos de los pobres deben desear ardientemente su abolición.[...]El principio de la gravitación no es más cierto que la tendencia que tienen estas leyes a convertir la riqueza y la fuerza en miseria y debilidad, a apartar el esfuerzo del trabajo” (Ricardo, David, Principios de Economía Política y Tributación, FCE, México, 1993,pp. 108-111). Ahora bien, aunque Senior era un partidario teórico del laissez faire, en la práctica no recomendó la abolición total de las leyes de pobres sino su reforma debido a las circunstancias políticas particulares. Esto, sin embargo, no contradice el hecho de que, aunque con alcances más limitados de aquellos a los que aspiraban los partidarios
} 
Reforma sólo era posible cuando el trabajo había sido concebido como un producto mercantil sometido a las leyes naturales de un mecanismo autorregulado. Sólo cuando esto sucedió, el criterio que determinaba el acceso a la asistencia pudo sostenerse en una distinción entre quienes tenían la capacidad para insertarse en el mercado y quienes no la tenían. Mientras los trabajadores fueron concebidos como "algo más" que un producto mercantil (sea como súbditos a los que un Estado paternal debía mantener, sea como sujetos de un derecho a la existencia producto de los aportes de su trabajo a la riqueza social), las intervenciones del gobierno no podían ser sometidas a restricciones definidas en torno al eje del mercado. Sin embargo, una vez que el trabajo comenzó a ser problematizado en las coordenadas de ese equilibrio autorregulado de las carencias, la propia acción del gobierno pudo ser definida en los términos dispuestos por esta nueva cartografía. ${ }^{297}$ Ciertamente, la Nueva Ley de Pobres no materializaba enteramente el sueño liberal, sin embargo, sí evidenciaba que una nueva forma de concebir el trabajo, la pobreza y las funciones activas del Estado había irrumpido en el pensamiento del siglo XIX.

Ahora bien, esta nueva forma de concebir las relaciones entre el Estado y la pobreza no sólo se postulaba como una especie de reformulación en los mecanismos de la administración estatal, sino como la condición de posibilidad para la irrupción de una nueva era en el mundo laboral, una era donde lo que primaría no sería ya el sometimiento y la dependencia a los poderes estatales, sino la libertad. Veamos.

\subsection{Libertad de trabajo}

.En la década de 1770, como Inspector de Finanzas de Luis XVI, Anne Robert Turgot presentó seis decretos para reformar la política económica de Francia. ${ }^{298}$ Dos de esos decretos afectaban especialmente al mundo del trabajo ya que establecían la abolición de un par de instituciones que habían jugado un importante papel el Antiguo Régimen: las corvées royales

más radicales del libre mercado, la Nueva Ley de Pobres estaba fundada sobre una distinción que reflejaba toda una nueva forma de problematizar el trabajo en la Europa del siglo XIX.

${ }^{297}$ Más que reducir al Estado al mínimo, el liberalismo funcionaba redefiniendo sus márgenes legítimos de acción en torno a la comprensión del mercado.

${ }^{298} \mathrm{Al}$ respecto remitimos al lector a la introducción biográfica del quinto volumen de las Obras completas de Turgot escrita por Gustav Schelle (Schelle, Gustav, Oeuvres de Turgot et documents le concernant, verlag de detley auverman KG, París, 1973. p.1ss. 
y las jurandes. ${ }^{299}$ En el primer caso, se buscaba acabar con una modalidad particular del trabajo forzado que había sido instaurada a mediados del siglo XVIII y era utilizada para el mantenimiento de obras públicas. ${ }^{300}$ En el segundo, Turgot pretendía poner fin a un complejo sistema de regulaciones extremadamente rígidas destinadas a la protección selectiva de trabajadores agremiados. ${ }^{301}$

Como ha mostrado Robert Castel en La Metamorfosis de la cuestión social, los dos siglos previos a la Revolución francesa estuvieron marcados por un doble movimiento alrededor de las poblaciones vulnerables. Mientras la llamada “policía de los pobres” tenía el objetivo de acabar con la mendicidad y el vagabundeo a través de la instauración del trabajo forzado, ${ }^{302}$ las corporaciones de oficios se presentaban como espacios de privilegio, en los cuales un conjunto de trabajadores adquiría reconocimiento y protección gracias a su adscripción en una forma de organización excluyente y autoritaria. ${ }^{303}$

Así, en los albores de la Revolución, el mundo del trabajo se levantaba sobre una doble asimetría: sea que la libertad de los individuos sufriera una violación por cuanto se les incorporaba al trabajo forzado; sea que su adscripción a una corporación les permitiera gozar de un conjunto de beneficios extraordinarios. Por tanto, no era ninguna casualidad que las medidas de Turgot fueran concebidas por los sectores “ilustrados” como parte de un programa destinado a “modernizar” el anquilosado régimen francés acabando con esas perniciosas distinciones en el mundo del trabajo.

Sin embargo, Turgot no sólo luchaba contra los privilegios estamentales y en favor de la igualdad jurídica, sino que lo hacía empuñando la bandera de la libertad:

Todas las personas de cualquier calidad y condición tendrán libertad de ejercer, en nuestro reino, la especie de comercio y profesión de artes y oficios que les plazca, y hasta ejercer varias; para lo cual eliminamos y suprimimos [...] todas las corporaciones y comunidades de

\footnotetext{
${ }^{299}$ Cfr, Castel, Robert, El ascenso...op.cit.p.61ss.

${ }^{300} \mathrm{Al}$ respecto el lector pude remitirse al reciente texto de Anne Conchon en los Cahiers d'histoire titulado "Le travail entre labeur et valeur: la corvée royale au XVIIIe siècle” consultado en: https://chrhc.revues.org/1973

${ }^{301}$ Para un análisis detallado de la función de las corporaciones en los siglos XVII y XVIII véase: Castel, Robert., La metamorfosis de la cuestión social. Una crónica del salariado. Paidos, Buenos Aires, 1977, p. 109ss.

302 Así, por ejemplo, el Abad de Saint-Pierre afirmaba: "En tanto que la abundancia procede siempre del trabajo y la miseria de la ociosidad, vuestra principal ocupación debe ser encontrar los medios de encerrar a los pobres y darles una ocupación para ganarse la vida Citado, en: Castel, Robert, El ascenso...,p.60.

${ }^{303}$ Castel, Robert,, El ascenso de...,op.cit.p.62.
} 
mercaderes y artesanos, así como los maestrazgos y jurandos (jurandes), y anulamos todos los privilegios, estatutos y reglamentos otorgados a dichas corporaciones. ${ }^{304}$

¿Acaso la igualdad y la libertad no eran los dos pilares del proyecto ilustrado? En ese sentido, el edicto de Turgot parecía del todo consecuente con las aspiraciones del mundo moderno. Sin embargo, el francés vinculaba rápidamente este llamado a la libertad con dos derechos sumamente peculiares. Por un lado, el derecho de los trabajadores a vender libremente la única propiedad que poseían, y, por el otro, el derecho de los empresarios a elegir libremente a sus empleados en función de las exigencias de la libre competencia:

Les debemos sobre todo protección a la clase de hombres que, sin más propiedad que su trabajo $(\mathrm{c} / \mathrm{n})$, tienen tanto más la necesidad y el derecho de emplear en toda su amplitud los únicos recursos que le permiten subsistir(c/n).

Todas las clases de ciudadanos se ven privadas del derecho de elegir a los obreros que querían emplear, y de la ventaja que les procuraría la competencia, en cuanto al bajo precio y a la perfección del trabajo. ${ }^{305}$

Así, frente a la asimetría del régimen laboral pre-moderno, la "libertad de trabajo" pretendía inaugurar un nuevo ordenamiento social. Como nunca antes, el trabajo era presentado como una actividad fundada en la reciprocidad de derechos y no en el dominio de unos sobre otros: por un lado, se encontraba el derecho de los desposeídos a vender libremente su trabajo y, por el otro, el derecho de los empresarios a obtener ese trabajo en el mercado en función de los precios determinados por la libre competencia.

Aunque las propuestas de Turgot fueron rápidamente desautorizadas por el Parlamento en el periodo de Luis XVI, marcaban la pauta que adoptaría el pensamiento liberal en los siguientes años. El 14 de junio de 1791, en plena etapa girondina, la Asamblea Nacional abolió las corporaciones argumentando que ningún “interés intermediario de la cosa pública” podía sustituir las relaciones entre el interés individual y el interés público. ${ }^{306}$ Según Isaac Le Chapelier, promotor de la legislación, "las convenciones libres de individuo a

\footnotetext{
${ }^{304}$ Lastra, José Manuel, “Las corporaciones de oficio y la libertad de asociación en Francia”, en: Revista de la Facultad de Derecho, UNAM, Número 223-224, Enero-Abril Año 1999. p.229.

${ }^{305}$ Citado en: Castel, Robert, La metamorfosis,...op.cit.p.149.

${ }^{306}$ Cfr, Lastra,...op.cit.p.230.
} 
individuo” eran las únicas que debían organizar los intercambios comerciales, incluido, desde luego, el intercambio de la capacidad de trabajar: ${ }^{307}$

Ya no hay corporaciones en el Estado; sólo existe el interés particular de cada individuo y el interés general. A nadie le está permitido inspirar a los ciudadanos un interés intermedio, separarlos de la cosa pública con un espíritu de corporación [...]. Hay que volver al principio de que fijar la jornada para cada obrero es algo que corresponde a las convenciones libres de individuo a individuo; a continuación, al obrero le corresponde mantener la convención a la que ha llegado con quien lo ocupa ${ }^{308}$

Unos cuantos años después, oponiéndose a las tesis desarrolladas por Sismondi en sus Nuevos principios de economía política, Jean Baptiste Say asumía de lleno esta nueva comprensión como parte de su teoría económica. Sismondi defendía que los dueños del capital debían hacerse cargo de la penosa situación de los trabajadores ya que eran precisamente ellos quienes se beneficiaban de los bajos salarios; ${ }^{309}$ para lo cual, el economista suizo proponía que el Estado debía obligar a los terratenientes y a los dueños de manufacturas a mantener a los obreros del campo y el taller. Sin embargo, desde la perspectiva de Say, este tipo de medidas representaban una verdadera amenaza contra la propiedad:

Equivaldría a renunciar a todo lo concerniente a la propiedad el que se gravara a una parte de la sociedad con el mantenimiento de otra clase, y que se le obligara a pagar una mano de obra cuando ningún producto puede resarcirla $[\ldots]^{310}$

En efecto, si el trabajo era una propiedad que se intercambiaba libremente con los empresarios, la regulación social de la riqueza era concebida como una violación a las condiciones “enteramente voluntarias” de esa transacción. En realidad, los obreros llevaban a cabo un contrato mercantil con los empresarios idéntico a cualquier otro: el trabajador se encontraba con el empresario para negociar libremente el intercambio de eso que Say llamaba

\footnotetext{
307 Y en 1804 los Códigos Napoleónicos incorporaran una forma particular de contrato destinada a la renta (louage) del trabajo (ouvrage) en su artículo 1779 del Libro tres, dedicado, sintomáticamente, a las formas de adquisición de la propiedad.

${ }^{308}$ Citado en : Castel, Robet, La Metamorfósis...op.cit.p.

${ }^{309}$ Según Sismondi esto era así porque eran precisamente ellos los que se beneficiaban de los salarios bajos. No obstante, Say refutaba esta consideración ya que, desde su perspectiva, los verdaderos beneficiados con la disminución del precio del trabajo eran los consumidores, pues, las mercancías tendían a bajar en la medida en que bajaba el precio de los salarios.

310 Say, Jean Baptiste, Tratado...op.cit.p.334.
} 
“la propiedad industrial del hombre”. ${ }^{311}$ Sin embargo, si, como proponía Sismondi, el Estado intentaba regular la distribución de la riqueza en favor de los trabajadores, limitaba el derecho de los empleadores a comprar el trabajo en condiciones de entera libertad.

Los bajos salarios, en caso de existir, debían ser atribuidos a las condiciones de esa negociación mercantil en el marco de las dinámicas naturales del mercado y no, como pensaba Sismondi, a un beneficio ilegitimo por parte de los patrones. Hacia 1830, Nassau W. Senior, uno de los principales responsables del Informe sobre las leyes de pobres, desarrollaba este mismo argumento en su cátedra de Oxford:

En el estado natural de la relación entre el capitalista y el trabajador, cuando la cantidad de salarios que se pague, y de trabajo que se haga, sean los temas de abierta negociación; cuando el trabajador sepa el valor justo que debe obtener por sus servicios para su patrón, él debe resentir cualquier caída en el precio de su trabajo [...], pero no es posible quejarse de ello como injusticia.[...] La conexión entre él y su patrón tiene la virtud de una asociación voluntaria, en la cual cada sector está consciente del beneficio, y cada uno siente que su propio bienestar depende, hasta cierto punto, del bienestar del otro. ${ }^{312}$

Si la relación contractual entre obrero y patrón era el resultado de una asociación libre, el trabajador no debía sentir como una injusticia la caída en los precios de esa propiedad que él ponía en venta de forma voluntaria. No sólo porque se trataba de un contrato acordado libremente, sino porque, como cualquier otra transacción mercantil, la definición del precio de la propiedad en venta respondía a la naturaleza del mercado y no a alguna voluntad arbitraria. $^{313}$

Pero, ¿cómo es que el mercado determinaba el precio de esa mercancía peculiar llamada trabajo? En este punto tanto Say como Senior se adscribían a la teoría de David Ricardo. A pesar de que en sus Principio de economía política y tributación el inglés había

311 “C’est violer la propriété industrielle d’un homme que de lui interdire l'usage de ses talents et de ses facultés, si ce n'est dans le cas où ils attentent aux droits d'un autre homme” (Say, Jean Baptiste, Collection...op.cit. p.134.).

312 Senior, Nassau, William, "Causas y soluciones de los disturbios presentes" en Textos Selectos de Grandes Economistas accesible libremente en www.eumed.net/textos/

${ }^{313}$ Esta concepción contrastaba con la aceptación del propio Smith de que la relación entre obrero y patrón se sustentaba generalmente en un contrato desigual. 
interpretado el trabajo como fuente del valor, ${ }^{314}$ en el capítulo 5 de mismo texto se refería al precio de la mano de obra de la siguiente manera:

El precio del mercado de la mano de obra es el precio que realmente se paga por ella, debido al juego natural de la proporción que existe entre la oferta y la demanda; la mano de obra es costosa cuando escasea, y barata cuando abunda. Por más que el precio de mercado de la mano de obra se desvíe de su precio natural tiende, al igual que los bienes, a conformarse con él. ${ }^{315}$

Ricardo definía los precios de las mercancías en términos de las fluctuaciones de la oferta y la demanda referidas a eso que Smith llamaba precio natural. ${ }^{316}$ Como ocurría con cualquier mercancía, el precio natural del trabajo estaba conformado por el costo necesario para solventar los factores que permitían su producción. No obstante, lo que debía producirse en este caso era el trabajo de un ser humano, de ahí que su precio natural estuviera determinado por aquello que resultaba necesario para reproducir la existencia de los hombres y la de su descendencia. En su Tratado de Economía Política, Jean Baptiste Say retomaba esta misma concepción según la cual los precios de la mano de obra estaban ceñidos a los costos de subsistencia:

Ya que los trabajos simples y burdos pueden ser ejecutados por cualquier hombre, a condición de que este vivo y tenga salud, la condición de vivir es la única requerida para que dichos trabajos sean puestos en circulación. Por eso el sueldo de esas labores casi no se eleva en cada país por encima de lo que es rigurosamente necesario para subsistir [...] Desde el momento en que basta con subsistir para cumplir con una labor, y este trabajo basta para subvenir a esta subsistencia, el hombre capaz de semejante trabajo no tarda en existir.

Sin embargo, aquí hay que hacer una observación. El hombre no nace con la estatura y la fuerza suficientes. Para llevar a cabo aun el trabajo más fácil. Esa capacidad que sólo se adquiere a los 15 o 20 años, más o menos, puede ser considerada como un capital que no se formó más que por la acumulación anual y sucesivo de los montos consagrados a criarlo. ¿Quién acumulo dichos montos? Suelen ser los padres del obrero, personas de la profesión que seguirá o de una análoga. Por consiguiente, es necesario que en esa profesión los obreros

\footnotetext{
314 “Que el trabajo es realmente el fundamento del valor de cambio de todas las cosas, con excepción de aquellas que no pueden incrementarse por la labor humana, es una doctrina sumamente importante dentro de la economía política” (Ricardo, David, Principios de economía política y Tributación, FCE, México, 1959, p.14-15). Ciertamente Ricardo comenzaba criticando a Smith por las confusiones generadas en torno a la definición del valor, sin embargo, no tardaba en repetir la misma operación. En efecto, en la Sección uno del Capítulo 1 de los Principios de economía política y tributación, Ricardo defendía que el valor debe ser determinado exclusivamente por la cantidad necesaria de trabajo para la producción de una mercancía y no por el valor de los cereales o la variación del precio del salario, tal como Smith terminaba sugiriendo

315 Ricardo, David, Principios ...op.cit. p.72

316 Cfr. Supra p. Sobre la manera en que Ricardo retoma la teoría de Smith al momento de analizar la “distribución de valor” Véase: Dobb, Maurice, Las teorías...op.cit.p.99ss y Bidet, Jacques Qué faire du Capital?, PUF, París, 1990, p 15ss.
} 
ganen un sueldo un poco superior a una simple existencia; es decir, que ganen con qué mantenerse y con qué cría a sus hijos. ${ }^{317}$

Así definido, el precio natural del trabajo fluctuaba en relación a la oferta y la demanda para determinar su precio de mercado, no obstante, Ricardo agregaba que, a pesar de dichas fluctuaciones este último tendía naturalmente a conformarse con aquél. Aquí había un irmportante desplazamiento respecto a la teoría de Smith. Mientras este último aspiraba a un estado progresivo en el que el aumento de la demanda de trabajo llevara a un incremento constante del salario, Ricardo afirmaba que el desarrollo del mercado hacia que este último inevitablemente se adecuara a su precio natural. En medio de esta divergencia no se encontraba otra cosa sino las leyes de la población de Malthus.

En efecto, siguiendo al británico, Ricardo pensaba que un aumento de los precios de la mano de obra tendería a hacer crecer la población y, con ella, la oferta de trabajo. Al haber más mano de obra que aquella que el mercado requería, su precio sería presionado a la baja hasta adecuarse finalmente a su precio natural. ${ }^{318}$ Ahora bien, si la propia naturaleza del mercado tendía a establecer el precio de la mano de obra en conformidad con su precio natural, resultaba aún más problemático quererlo modificar de manera artificial mediante el decreto de un aumento en su precio efectivo. En esto, Ricardo coincidía con Malhus cuando este último afirmaba:

No hay nadie que desee con más fervor que yo el aumento del precio efectivo del trabajo; pero la tentativa de conseguirlo obligando a subir el precio nominal [...] tiene que ser rechazada por toda persona como algo pueril e ineficaz. Cuando se deja al precio del trabajo alcanzar su novel natural, resulta un importante barómetro político, que expresa la relación entre la oferta de provisiones y la demanda de ellas. ${ }^{319}$

Say retomaba estos argumentos en su crítica a Sismondi y en su defensa irrestricta de la libertad de mercado. Desde su perspectiva, si el Estado obligaba a los empresarios a mantener a los obreros, los hacía pagar la mano de obra por encima de su precio mercantil

\footnotetext{
${ }^{317}$ Say, Jean Baptiste, Tratado...op.cit.p. 329. Cuando, en El Capital, Marx realice su Crítica a la economía política, retomará ambos supuestos, para mostrar el impasse al que inevitablemente lleva tanto la consideración de que el valor del trabajo se define por la cantidad necesaria para la subsistencia del trabajador, como por las interacciones de la oferta y la demanda. (Cfr, Marx, Karl...op. cit.p.277ss).

${ }^{318}$ Cfr, Dobb, Maurce, Teorías...op.cit.pp.105-106.

${ }^{319}$ Malthus, ,„,op.cit.pp.327-328.
} 
que, tarde o temprano, tendería a conformarse con el costo de subsistencia. Esta especie de condena a una clase en su conjunto no era, sin embargo, el resultado de ninguna injusticia, sino la consecuencia necesaria de los propios mecanismos de un mercado que reconocía la libertad de todos los individuos.

En tanto que las relaciones laborales eran concebidas como el resultado de contratos individuales libres entre partes jurídicamente iguales en función de precios determinados de forma natural, la intervención de toda entidad artificial estaba enteramente prohibida ya que distorsionaba las tendencias naturales de la población y el mercado. ${ }^{320}$ Sin embargo, además de la intervención del Estado, había otro elemento que amenazaba el equilibrio de los precios, a saber: la asociación de los trabajadores. En efecto, cuando los obreros se unían entre ellos para exigir un mejor salario, ¿no amenazaban la tendencia natural del mercado haciendo que el trabajo se vendiera por encima de su precio natural?, ¿no violentaban los contratos libres entre individuos imponiendo sobre el patrón una fuerza ilegítima?

No era casual que en su artículo cuatro, la Ley le Chapelier estableciera una pena económica y hasta un año de privación de los derechos cívicos a aquellos que intentaran formar cualquier coalición de trabajadores. En Francia, esta prohibición durará más de ocho décadas hasta que, durante la III República, fuera instaurada la llamada Ley Waldeck Rousseau que legalizaba los sindicatos. De igual forma, el Informe sobre las Leyes de Pobres en Inglaterra, en parte redactado por el propio Senior, proponía penas para cualquier intento de asociación laboral e incluso el pago de indemnizaciones por parte del gobierno a los patrones afectados por las huelgas de los trabajadores.

De ahí esa gran paradoja que acompañará al pensamiento liberal durante prácticamente todo el siglo XIX: al mismo tiempo que se erigía como el máximo defensor de la libertad individual, apelaba a la fuerza del Estado ${ }^{321}$ para disuadir cualquier intento de asociación entre los trabajadores. Paradoja sí, mas no contradicción. En la medida en que el trabajo era problematizado como una propiedad intercambiable en condiciones de igualdad

\footnotetext{
${ }^{320}$ Un equilibrio que, como hemos visto, estaba plenamente ligado a las leyes de la población. Say retomaba el argumento de Ricardo según el cual, un aumento en los salarios de la clase trabajadora repercutiría en un crecimiento de la población, a lo cual le seguiría un desequilibrio entre la oferta y la demanda de trabajo. En efecto, en dichas circunstancias habría más trabajadores de los requeridos y, por lo mismo, el salario sería presionado a la baja. Así, la tendencia natural de las cosas haría que el precio del trabajo se circunscribiera al costo de la subsistencia.

${ }^{321}$ En 1803 se aprueba una ley que prohíbe las coaliciones de patrones y obreros y el derecho de huelga, mientras que en el código penal de 1810 se establecen penas punitivas cárcel para sus transgresores.
} 
jurídica en virtud de los precios determinados por el mercado, la asociación de cualquiera de las partes involucradas era concebida como una transgresión a los términos contractuales y a las leyes del mercado.

Sin embargo, la imposibilidad de asociación por parte de los trabajadores no sólo tenía efectos sobre sus libertades civiles, sino que impedía cualquier tipo de resistencia ante las terribles condiciones que se vivían en el taller o en la fábrica. En buena medida, la novedad del dispositivo liberal se localiza en haber lograr presentar como resultado de la libertad y la igualdad, un conjunto de relaciones de dependencia en el interior mundo del trabajo que se fundaban, precisamente, en la restricción de su libertad de asociación.

\section{Técnicas de gobierno sobre los trabajadores: entre el control de los tiempos y la gestión de los cuerpos}

Imaginémonos, dice Foucault en la penúltima clase del curso de 1973, una sociedad de trescientos a cuatrocientas personas en las cuales el empleo del tiempo sería el siguiente: "levantarse a las 5 horas con cincuenta minutos para el aseo, desayuno; taller de 6h10 de la mañana a $20 \mathrm{~h} 15$ de la noche, con una hora para la comida; cenar y acostarse a las $21 \mathrm{~h}$ ”. ${ }^{322}$ Este cuadro en el que hombres y mujeres se dedican por entero a trabajar, en el que la comida, el aseo, incluso la hora de dormir, han sido estipuladas con rigor antes de cualquier decisión personal, corresponde al reglamento de una fábrica de tejidos de seda en l'Ain, Francia, hacia el año de 1840. Así, entre textiles y máquinas, la vida se confunde con el empleo y la sociedad con el centro de trabajo. Al menos esa es la impresión de un personaje como Reybaud quien, en la década de 1860, describe de esta manera una fábrica de prendas de lana cerca de Villeneuvette: "La comunidad -señala- está toda encerrada en la fábrica. Ahí la vida civil y la vida industrial son confundidas”. ${ }^{323}$

Unos años antes, en 1845, Engels había escrito La situación de la clase obrera en Inglaterra, en cuyas páginas narraba las penosas condiciones de trabajo del nuevo proletariado, muy particularmente aquellas que se vivían en las fábricas de Manchester. En uno de los pasajes que Marx retomará más de 20 años después, el autor de La familia, la propiedad privada y el Estado señalaba:

\footnotetext{
${ }^{322}$ Foucault, Michel, La Société punitive, Gallimard, Pais, 2013, p.207

323 Ibid.p.208.
} 
El obrero debe estar en la fábrica a las 5.30 de la mañana; si llega un par de minutos tarde, se lo castiga; si se presenta 10 minutos después de la hora, no se lo deja entrar hasta después del desayuno y pierde entonces la cuarta parte del jornal. Tiene que comer, beber y dormir a la coz de mando. La despótica campana lo saca de la cama y lo hace terminar su desayuno y su almuerzo. ¿Y qué ocurre en la fábrica misma? Aquí el fabricante es el legislador absoluto. Promulga los reglamentos fabriles que le placen, modifica y amplía su código según se le antoje y aunque incluya en él las cosas más descabelladas. ${ }^{324}$

En realidad, la descripción del inglés no exageraba las cosas ni un ápice. Hacia mediados del siglo XIX el poder del patrón en las fábricas inglesas era una extensión del poder del pater familias en el dominio privado-familiar. Poco importaba que las sociedades modernas hubieran decretado la emancipación de todos los hombres en la esfera civil: al entrar en el centro de trabajo, la única voluntad que debía ser obedecida era la voluntad del patrón, aun cuando esto supusiera terribles efectos sobre la propia integridad de las personas.

Así, por ejemplo, en un mitin realizado en la alcaldía de Nottingham el mes de enero de 1860, el juez de ese condado presentaba una imagen semejante a la descrita por Engels, refiriéndose, sin embargo, a una realidad más impactante:

A las 2, a las 3, a las 4 de la mañana se arranca de las sucias camas a niños de 9 a 10 años y se los obliga a trabajar por la mera subsistencia hasta las 10, las 11 o las 12 de la noche mientras sus miembros se consumen, su complexión se encanija, se les embotan los rasgos faciales y su condición humana se hunde por completo en un topor pétreo, extremandamente horrible de contemplar ${ }^{325}$

Tanto en la fábrica de l’Ain, como en la descripción de Engels o en la escena de Nottongham, asistimos a una forma de dirigir las conductas de los sujetos donde el control minucioso de los tiempos resultaba esencial. Sin duda, los trabajadores agrícolas del Antiguo Régimen vivían apremiados por los tiempos de las cosechas o los plazos, muchas veces arbitrarios, que sus superiores establecían; sin embargo, la consistencia de esa temporalidad era muy distinta a la que se vivirá en los talleres y las fábricas del siglo XIX. En esos centros de trabajo cerrados -de los cuales Émile Zola describía en Germinal cómo diariamente se “tragaban a los hombres”-, imperaba una administración tan escrupulosa del tiempo que era capaz de planear todas las horas e incluso todos los minutos del día. Así, por ejemplo, en uno

\footnotetext{
${ }^{324}$ Engels, F..citado en Marx, Karl, El Capital. Tomo.I.Vol..2...op.cit.p.519

${ }^{325}$ Citado en: Marx, Karl, El Capital. Tomo I.Vol.1...op.cit. p. 293.
} 
de los Reportes de los Inspectores fabriles fechado el 30 de abril de 1858 se narra cómo, instaurada la jornada de 12 horas, los patrones buscaban la forma de aprovechar cada minuto de tiempo en la fábrica, aun cuando esto implicara transgredir toda legalidad:

El fabricante tramposo hace que el trabajo comience un cuarto de hora (a veces más, a veces menos) antes de las 6 de la mañana y lo finaliza un cuarto de hora ( a veces más, a veces menos) antes de las 6 de la tarde. De la media hora permitida nominalmente para el desayuno retacea 5 minutos y otros tantos al final, y 10 minutos al principio y otros 10 al final de la hora otorgada nominalmente para el almuerzo. Los sábados hace trabajar un cuarto de hora (a veces más, a veces menos) después de las dos de la tarde. ${ }^{326}$

Pero esta especie de devoción por el cálculo de los tiempos no sólo afectaba la actividad laboral en el interior del centro de trabajo, sino que era capaz de extender sus tentáculos a todas a las demás esferas de la vida. Si, como decía Reybaud, la vida industrial y la vida civil se confundían, era sólo porque esta última se volvía casi inexistente. Los escasos momentos de descanso o de ocio, estaban determinados por la gestión de los tiempos que tenía lugar en la esfera laboral. En un informe sobre el trabajo infantil de 1865, el comisionado White señalaba:

Durante el periodo laborable de la semana, 6 horas son el periodo ininterrumpido más largo de descanso, y de esto hay que reducir el tiempo para ir a la fábrica y volver de ella, lavarse, vestirse, comer, todo lo cual insume tiempo. Queda así, en verdad, un tiempo brevísimo para el descanso, y nada para jugar y tomar aire fresco, salvo que sea a expensas del sueño, tan indispensable para niños que ejecutan un trabajo fatigoso y en una atmósfera tan caldeada ${ }^{327}$

Dos años antes, la Comisión de Empleo para Niños había publicado su primer informe sobre el trabajo infantil en el que, entre muchos otros, recogía los testimonios de J. Murray, un niño de doce años que trabajaba en el hilado del algodón:

Entro a las 6 de la mañana -afirmaba el infante-. A veces a las 4. Anoche trabaje toda la noche, hasta las 8 de esta mañana. Desde anoche no me meto en la cama. Hubo otros ocho o nueve muchachos que trabajaron toda la noche. Todos menos unos volvieron esta mañana. ${ }^{328}$

Los ejemplos son casi infinitos: niños trabajando dobles jornadas en fábrica distintas para burlar las inspecciones; hombres obligados a trabajar en sus horas de comida para

\footnotetext{
326 Ibid.p.289.

${ }^{327}$ Citado en: Ibid.p.318

${ }^{328}$ Citado en: Ibid.p.294.
} 
aprovechar cada minuto; mujeres trabajando días enteros sin descanso alguno y un muy largo etcétera, eran el pan de cada día de este naciente mundo industrial. En todos los casos se trataba del tiempo, de aminorarlo hasta el cansancio, exprimirlo a más no poder, estrujarlo de todas las formas posibles según unas normas y unas reglas que eran gestionadas y administradas por otro.

En Vigilar y Castigar, Michel Foucault había mostró que esta gestión minuciosa del tiempo no era exclusiva de la fábrica, sino que, desde el siglo XVIII, había comenzado a funcionar en instancias como la escuela, la milicia y, más recientemente, la cárcel moderna. ${ }^{329}$ Sin embargo, tanto en la milicia como la cárcel este mecanismo de control estaba vinculado a fines extremadamente precisos. ${ }^{330}$ En el primer caso, la gestión del tiempo era un instrumento necesario para organizar a una multitud dispersa con el fin de actuar de manera sincronizada; mientras que en la prisión moderna, formaba parte de un complejo mecanismo en el que su administración, vinculada a la privación de la libertad, supuestamente terminaría por moralizar a los delincuentes impactando directamente en la corrección de su conducta:

En la prisión, el gobierno puede disponer de la libertad de la persona y del tiempo del detenido; entonces se concibe el poder de la educación que, no sólo en un día sino en la sucesión de los días y hasta de los años, puede regular para el hombre el tiempo de vigilia y de sueño, de actividad y de reposo, la cantidad y al duración de las comidas [...] el tiempo de la oración, el uso de la palabra y, por así decirlo, hasta el del pensamiento, esa educación que, en los simples y breves trayectos del reflectorio al taller, del taller a la celda, regula los movimientos del cuerpo e incluso, en los momentos de reposo, determina los empleos del tiempo, esa educación, en una palabra, que entra en posesión del hombre entero, de todas las facultades físicas y morales que hay en él y del tiempo en el que él mismo está inserto. ${ }^{331}$

${ }^{329}$ Hacia el siglo XIX, la vinculación entre la milicia y la fábrica era frecuente. el propio Raybaund comparaba la fábrica de Villeneuvette con un “régimen militar” y, durante el II Imperio, un poeta de Lille podía escribir versos como estos: "Soy un soldado, un soldado de la industria/Como tú, yo tengo mi bandera./ Mi trabajo ha enriquecida a la Patria” Citado en Hobswan, Eric, La era del capital 1848-1875, Crítica, Barcelona, 2003, p.226.

${ }_{330} \mathrm{Al}$ respecto véase la interesante crítica que Stéphane Legrand en su artículo "El marxismo olvidado de Foucault” en donde plantea que el análisis de las disciplinas que Foucault realiza en Vigilar y castigar parece yuxtaponer un conjunto de características similares en distintas instituciones que, a falta de un análisis de las causas que explican esas disciplinas en cada institución, el francés termina por unificar en el concepto ciertamente problemático de una "sociedad disciplinaria” Lemke, T; Legran, S; Marx y Foucault, Nueva Visión, Buenos Aires, 2006,p.21ss.

${ }^{331}$ Foucault, Michel, Vigilar y castigar, siglo XXI, México, p.271-272. 
Durante mucho tiempo la idea de que la inserción al mundo laboral promovía una vida que moralizaba a los individuos también acechó el imaginario de la nueva industria. No obstante, aunque el trabajo industrial en general y la fábrica en particular no fueron inmunes a esta creencia, ${ }^{332}$ conviene no confundir las cosas. Si los dueños de las fábricas apelaban a las virtudes moralizadoras que el trabajo aportaba a la clase obrera, era sólo de forma secundaria. En realidad, el aprovechamiento casi obsesivo de los tiempos estaba enteramente vinculado a otra finalidad: incrementar la productividad de los seres humanos para obtener un mayor rendimiento del capital. Esto no sólo resultaba evidente para los patrones y los obreros, sino también para los inspectores fabriles, tal como queda de manifiesto en un Reporte fechado el 31 de octubre de 1861:

Debe recordarse que para el fabricante es de máxima importancia que su maquinaria este ininterrumpidamente en movimiento. [...] Cada detención de un minuto no sólo significa una pérdida de fuerza motriz, sino de producción. De ahí que los capataces, interesados en la cantidad de artículos producidos, acucien a los obreros a que mantengan la máquina en movimiento ${ }^{333}$

Ahora bien, como fundamentalmente se trataba de la productividad, la exigencia de aprovechar el tiempo in extremis se encontraba estrechamente vinculada con otra igualmente necesaria: la gestión de los cuerpos. Con la introducción de la máquina en las fábricas y la sustitución de las viejas herramientas de trabajo, esta última exigencia adquirirá plena relevancia. Y es que, en tanto más acoplados estuvieran los obreros a la nueva maquinaria, más tiempo podría aprovecharse y más beneficios podrían obtenerse. Así, el movimiento del cuerpo debía adaptarse al movimiento de la gran maquinaria para aprovechar mejor los esfuerzos del obrero. El resultado que este “minúsculo” cambio generaba en la productividad

332 Todavía a principios del siglo XX Antonio Gramsci se sentía asombrado por los métodos de trabajo implementados por Henry Ford ya que, además de mejorar la producción, ayudaban a disciplinar a los trabajadores, una condición necesaria para construir una sociedad alternativa: "Parece posible responder que el método de Ford es racional; es decir, que debería generalizarse; pero que para ello es necesario un largo proceso durante el cual deben producirse cambios en las condiciones sociales, en las formas de vida y en los hábitos de los individuos ”. Una de las cosas que más le interesaba al filósofo italiano era el efecto del trabajo disciplinado en la vida sexual de los hombres, pues, si bien pudiera parecer que al mantener una disciplina estricta en la fábrica se "mecaniza la función sexual” de los trabajadores "en realidad estamos tratando del crecimiento de una nueva forma de unión sexual, despojada del color llamativo y deslumbrante del oropel romántico típico del pequeño burgués y del holgazán bohemio. La exaltación de la pasión no puede reconciliarse con los gestos cronometrados de los movimientos productivos conectados con automatismo plenamente perfeccionado”. Gramsci, A. “Americanism and Fordism”, citado en: Wollen, Peter, El asalto a la nevera, Akal. Madrid, 2006, p.45-46.

${ }^{333}$ Marx, Karl, El Capital. Tomo I. Vol.2...op.cit. p.509. 
sorprendía a los propios creadores de las máquinas. En muy poco tiempo el trabajo que otrora realizaban dos obreros podía ser realizado por uno siempre y cuando hiciera de su cuerpo una extensión de la máquina. Así, en una carta escrita en 1852 por el ingeniero civil James Nasmyth se podía leer:

La moderna máquina de vapor, con la misma cantidad de caballos de fuerza nominales, funciona con mayor potencia que antes debido a los perfeccionamientos introducidos en su construcción [...] Por eso, aunque proporcionalmente a lso caballos de fuerza nominales se emplea el mismo número de operarios que antes, se utilizan menos brazos en proporción a la maquinaria de trabajo ${ }^{334}$

Pero el proceso por el que se introdujo la maquinaría al centro de trabajo no sólo llevaba a los obreros a adaptar sus cuerpos al funcionamiento y a los ritmos de esos nuevos gigantes metálicos, sino que traía consigo otra pérdida acaso más importante: la del control sobre sus instrumentos de trabajo. En efecto, con el desarrollo de la máquina el trabajador dejaba de ser dueño del proceso productivo para convertirse en una especie de engranaje al servicio de la producción. En ese sentido, como señalaba Marx, la situación del trabajador industrial no sólo contrastaba con la del trabajador agrícola, sino con la del artesanado y el trabajador el manufacturero:

En la manufactura y el artesanado el trabajador se sirve de la herramienta; en la fábrica sirve a la máquina. Allí parte de él el movimiento el movimiento del medio de trabajo; aquí es él quien tiene que seguir el movimiento de éste. En la manufactura los obreros son miembros de un mecanismo vivo, En la fábrica existe un mecanismo inanimado independiente de ellos, al que son incorporados como apéndices vivientes. ${ }^{335}$

No obstante, la gestión de los tiempos, la adaptación del cuerpo a las exigencias de la nueva maquinaria y la pérdida de control sobre las herramientas de trabajo, no eran las únicas formas de sujeción a la que estaban sometidos los obreros en el taller y en la fábrica. De manera análoga a lo que ocurría en el ejército o la cárcel, el trabajo industrial debía estar anclado en un sistema complejo de vigilancia capaz de asegurar su acción disciplinada. Como sucedía con el guardia en la prisión o el oficial en la milicia, el capataz era el encargado de

\footnotetext{
${ }^{334}$ Citado en: Marx, Karl, El Capital. Tomo I. Vol.2...op.cit. p.506

335 Ibid.p.515.
} 
vigilar la acción cotidiana de los trabajadores. No era casual que, para hablar del origen del trabajo de supervisión, Marx echara mano de una analogía en la que relacionaba el papel del capataz en el régimen fabril con las funciones del oficial en la milicia:

La subordinación técnica del obrero a la marcha uniforme del medio de trabajo y la composición peculiar del cuerpo de trabajo, integrados por individuos de uno u otro sexo y pertenecientes a distintos niveles de edad, crean una disciplina cuartelaría que se desenvuelve hasta constituir un régimen fabril pleno y que desarrolla cabalmente el trabajo de supervisión [...] y, por tanto, a la vez, la división de los obreros entre soldados rasos de la industria y suboficiales militares ${ }^{336}$

Con todo, el poder del capataz era limitado; en realidad, su capacidad de gobernar a los otros dependía de la voluntad del patrón. Era él quien, como afirmaba Marx en el Manifiesto, le abría la puerta a una nueva forma de “despotismo”. ${ }^{337}$ La frase del alamán no era una simple ocurrencia. En teoría con la Revolución de 1789 el yugo paternal de un gobierno todopoderoso había sido suprimido de la esfera civil, sin embargo, ocurría que en el mundo de la fábrica el capataz fungía como el representante de un nuevo poder absoluto: el poder de los patrones. Durante su estancia en el lugar de trabajo, los obreros estaban sometidos, como los súbditos al déspota, a una voluntad ajena que no podía ser cuestionada. Zolá ilustraba bastante bien el tipo de relación existente entre el patrón y los trabajadores, e, inclusive, entre el patrón y los capataces, en un célebre pasaje de su novela Germinal:

-¡Obedezcan sin replicar [dijo el patrón]

Maheu, a pesar de la cólera que poco a poco iba adueñándose, dijo aún con relativa calma: -Si nos pagaran lo suficiente, apuntalaríamos mejor.

[El patrón] se encogió de hombros sin contestar. Después de bajar del corte, terminó diciendo desde abajo:

-Todavía les queda una hora, pónganse todos al trabajo [...]

Los mineros acogieron estas palabras con un sordo gruñido. Tan sólo los contenía la fuerza de la disciplina; esa disciplina militar que hacía que desde el último peón al capataz mayor se doblegaran al [patrón]. ${ }^{338}$

\footnotetext{
${ }^{336}$ Marx, Karl, El Capital...p.517. La analogía entre la milicia y la fábrica servía muy bien para mostrar que ésta última operaba mediante un sistema jerarquizado donde la gran mayoría de los participantes estaba sujeta a formas de dependencia prácticamente ilimitadas, sin embargo, hay que insistir en que esto no demostraba una comunidad de objetivos entre ambas instituciones. En realidad, la finalidad del capataz era sumamente precisa, a saber: se trataba de lograr una coordinación casi perfecta entre la fuerza humana y el movimiento de la máquina para aumentar la productividad de los sujetos.

${ }^{337}$ Marx, Karl, El Manifiesto...op.cit. p.163.

${ }^{338}$ Zola, Émile, Germinal, Gernika, México, 2011, p.51
} 
Así, las necesidades productivas del "régimen fabril”, orillaban al trabajador a una forma de dependencia extrema; una dependencia tal que, de la niñez a la muerte, casi todo el tiempo de su vida estaba sometido a las exigencias de una voluntad ajena encarnada en una especie de gigante metálico. Las consecuencias que una vida como esta debía producir en los cuerpos de los trabajadores son fáciles de sospechar: enfermedades, malformaciones, envejecimiento prematuro y, finalmente, la muerte:

Las deformaciones de la columna vertebral -señalaba el Dr. Loudon después de largos años de atender a los trabajadores fabriles- son muy frecuentes entre los obreros. Algunas de ellas, como consecuencia de exceso de trabajo físico, otras como consecuencia de un trabajo prolongado sobre una constitución originariamente débil o debilitada por una mala alimentación. Los estropeados parecían ser más frecuentes que estas enfermedades; las rodillas estaban torcidas hacia adentro, los tendones de los tobillos muy frecuentemente aflojados y distendidos y los huesos largos de las piernas, torcidos. Eran sobre todo los extremos de esos huesos largos los que se hallaban deformados e hipertrofiados, y esos pacientes provenían de fábricas donde con frecuencia se trabajaba prolongadamente. ${ }^{339}$

Y si la muerte no ponía fin a una vida de entera dependencia en el interior del centro de trabajo, no por ello la espada de Damocles dejaba de pender sobre sus cabezas. Cuando el cuerpo se hacía viejo, cuando las extremidades ya no daban más de sí después de años de ardua labor, cuando un inesperado accidente le impedía seguir trabajando o cuando una repentina enfermedad lo invadía, el trabajador estaba destinado a la miseria y al vagabundeo. ${ }^{340}$

Faltarán aún algunas décadas para que, retomando el lenguaje del derecho y vinculando sus necesidades a las obligaciones del Estado, los trabajadores logren tejer redes de seguridad y protección social que les brinden un mínimo de certidumbre, sin embargo, en el seno mismo del siglo XIX, ser trabajador en la fábrica o en el taller implicaba estar condenado a una vida sujeta al poder patronal y a la dependencia sin más esperanza que alargar la propia subsistencia lo más posible:

Nous travaillons -escribía en 1833, Grignon, un obrero de taller- 14 et 18 heures par jour, dans l'altitude la plus pénible; notre corps se déforme et se casse; nos membres s'engourdissent et perdent leur agilité, leur vigueur ; notre santé se ruine, et nous ne quittons

${ }^{339}$ Citado en: Engels, Friedrich. La situación de la clase obrera en Inglaterra, Buenos Aires, Editorial Futuro, 1965, p. 165.

${ }^{340}$ Cfr. Hobswan, Éric, La Era del Capital...op,cit. pp.230ss. 
l'atelier que pour entrer à l'hôpital [...] travailler, toujours travailler, toujours produire sans jouir de rien, sans posséder seulement le nécessaire! Notre salaire, insuffisant, déjà s pour le célibataire, ne peut nourrir une famille ; des aliments grossier et malsains, des vêtements incommodes, des guenilles, c'est toutes ce qu'il peut nous procurer. Aussi le moindre accident qui vient occasionner une dépense imprévue ou suspendre notre travail, menace bientôt notre existence. ${ }^{341}$

\section{Dependientes libres: la paradoja liberal}

¿Cómo era posible, entonces, que la situación de extrema dependencia en la que vivían los trabajadores fuera compatible con un concepto como el de libertad, por más moderno que éste se reivindicara? Quizás fueron Marx y Engels quienes, antes que nadie, sacaron a la luz, la relación intrínseca entre el funcionamiento de los discursos vinculados al liberalismo y las técnicas de poder que tenían lugar en el interior de la fábrica. Desde luego que antes de ellos los propios obreros daban testimonio de sus sufrimientos cotidianos, pero tanto Engels -en la Situación de la clase obrera en Inglaterra- y con mayor rigor Marx -en el El Capital- fueron capaces de evidenciar la relación entre esos testimonios y las necesidades internas al funcionamiento de los saberes que daban coherencia al liberalismo.

Desde mediados de la década de 1840, Engels expresaba con toda claridad las cosas al analizar las condiciones de los trabajadores ingleses:

¿Y qué ocurre en la fábrica misma? Aquí el fabricante es el legislador absoluto. Promulga los reglamentos fabriles que le placen; modifica y amplía su código según se le antoje, y aunque incluye en él las cosas más descabelladas, los Tribunales dicen al obrero: Como has concertado voluntariamente este contrato, ahora estas obligado a cumplirlo. ${ }^{342}$

Como vimos, en el interior del dispositivo liberal, la relación entre un obrero y un patrón era considerada como una transacción equivalente a la que tenía lugar entre dos comerciantes movidos exclusivamente por su interés personal. Así, la venta de esa nueva mercancía llamada trabajo se presentaba como un momento más de las dinámicas inherentes al mercado. Así, las relaciones laborales de extrema dependencia podían presentarse como la consecuencia ineludible de aceptar la libertad en el ámbito mercantil: dado que los trabajadores asalariados habían sido presentados como propietarios de una mercancía, tenían

\footnotetext{
${ }^{341}$ Citado en: Faure...op.cit. p.56-57.

${ }^{342}$ Citado en Marx, Karl, El Capital...op.cit..p.265.
} 
derecho a negociar su precio libremente atendiendo a las condiciones estipuladas por el mercado. 343

Precisamente por ello, siempre que el contrato de compraventa hubiera sido realizado conforme a la ley, la utilización que los empresarios hacían de esa mercancía en el centro de trabajo no era más que una extensión del acuerdo libremente pactado con anterioridad. Así, ni la gestión del tiempo, ni la vigilancia perpetua, ni la sumisión a la máquina, eran entendidas como formas de dependencia contrarias a los ideales de la modernidad: puesto que habían sido aceptadas libremente al momento de consentir las condiciones de un contrato de compraventa mercantil eran una extensión de ese acuerdo voluntario.

El empresario, por su parte, podía argumentar que, tal y como ocurría con todo contrato, el comprador de una mercancía era libre de usarla de la manera que deseara una vez finalizada dicha transacción. En El Capital, Marx señalaba que ese era precisamente el argumento de los empresarios para justificar las penosas condiciones de los obreros. Así, remitiendo a "la ley del intercambio mercantil” planteada por los economistas podía afirmarse que en el mercado se intercambiaban mercancías con un valor equivalente en condiciones de plena libertad. Una vez realizado este intercambio, el uso de las mismas también debía ser entendido como una expresión de la libertad para consumir la mercancía comprada de forma enteramente voluntaria:

El capitalista -dice Marx- se remite a la ley del intercambio mercantl. Al igual que cualquier otro comprador, procura extraer la mayor utilidad posible del valor de uso que tiene su mercancía [...] cuando procura prolongar lo más posible la jornada laboral y convertir, si puede, una jornada laboral en dos, reafirma su derecho en tanto comprador. ${ }^{344}$

Ahora bien, si el trabajo era vendido en condiciones de libertad e igualdad mercantil, ¿no resultaba ilógico establecer restricciones al uso de esa mercancía? Para buena parte de los pensadores liberales, las legislaciones fabriles que se intentaban implantar en la época implicaban una violación a la libertad de obreros y patrones. ${ }^{345}$ De la misma manera que el establecimiento de impuestos o la limitación de aquello que podía venderse en el mercado

\footnotetext{
${ }^{343}$ Marx fue absolutamente consciente de ello. En una nota al pie de la Sección Segunda de El Capital afirma: "Lo que caracteriza, pues, a la época capitalista, es que la fuerza de trabajo reviste para el obrero mismo la forma de una mercancía que le pertenece, y su trabajo la forma de trabajo asalariado” (Ibid.p.207).

344 Marx, Karl, El Capital Tomo I. Vol1 ...op.cit. pp.281-282.

${ }^{345}$ Cfr. Ibid.p.335ss.
} 
era interpretado como una violación a la propiedad, el establecimiento de reglas en el interior del centro de trabajo impuestas por el Estado era presentado como una amenaza a la libertad para hacer uso de una propiedad que se había adquirido en el marco de un contrato plenamente legítimo.

Así, por ejemplo, en un informe escrito el 12 de mayo de 1862 Lord Howard de Walden, plenipotenciario inglés en Bruselas, narraba cómo fue que durante años los empresarios bloquearon el intento de poner restricciones al trabajo infantil esgrimiendo el argumento de que ese tipo de prácticas violaban el principio de la libertad de trabajo:

El señor Rogier, el ministro, me explicó que ni una ley general ni ningunas regulaciones locales limitan el trabajo infantil; que el gobierno, durante los últimos tres años, tuvo en cada período de sesiones la idea de proponer a las cámaras una ley sobre el punto, pero que siempre encontró un obstáculo insuperable en la celosa repugnancia por toda ley que contradijera el principio de una perfecta libertad del trabajo. ${ }^{346}$

Pero se ve hasta qué punto esta peculiar comprensión de las cosas se sostenía en el hecho de haber problematizado el trabajo como una mercancía más sujeta a la libertad de intercambio. En ese contexto, el Estado debía garantizar las condiciones para hacer posibles contratos en el ámbito civil, pero no debía intervenir en el uso que los seres humanos hacían de su propiedad pues eso implicaba violar la libertad de los individuos y poner el riesgo las dinámicas naturales del mercado. Sólo de esta manera se comprende que los reglamentos fabriles que comprimían el tiempo de los trabajadores hasta excesos insospechados, que establecían una vigilancia perpetua de su labor y que supeditaban su existencia al ritmo de las máquinas pudiera ser complementaria con un discurso de libertad e igualdad; sólo así era posible que el dispositivo liberal se presentara como el horizonte de racionalidad al que aspiraba la modernidad.

Ahora bien, si en el marco del discurso liberal se impedía que los obreros se organizarán entre sí o que se establecieran leyes al interior de la fábrica que los protegieran como integrantes de un gremio o una clase, no era porque el liberalismo decimonónico partiera de una posición en la cual los impulsos del individuo se valoraran por encima de los impulsos colectivos. En realidad, se trataba menos de restringir cualquier mecanismo de acción social que de trazar la línea que distinguía los ámbitos en los cuales su ejercicio

${ }^{346}$ Ibid. 
resultaba benéfico para la sociedad y aquellos en los que no podía sino resultar perjudicial. De ahí, como veremos, esa distinción tan cara al pensamiento liberal entre el espacio que el correspondía al derecho y el lugar que debía asignársele a la beneficencia.

\subsection{Beneficencia y derecho al trabajo}

Aunque el dispositivo liberal del siglo XIX sólo pudo operar cuando el trabajo fue problematizado sobre el fondo del mercado, su objetivo fundamental no era mercatilizar todas las relaciones sociales, ni instar a los sujetos a asumir su propia identidad en términos empresariales. ${ }^{347}$ En realidad, la emergencia del mercado no venía a sustituir al Estado como la institución encargada de procesar los conflictos sociales, tampoco tenía la función de suplantar los mecanismos del derecho para establecer el imperio de los intereses privados y, mucho menos, proclamaba una visión atomizada de los seres humanos en tanto sujetos reducidos a un “individualismo posesivo”. Por extraño que parezca, en el seno mismo del proyecto liberal abundaban los llamados a la solidaridad, a la virtud, al desinterés y al más alto compromiso con el prójimo, así como una férrea defensa de la necesidad del Estado y las instituciones de derecho.

Lo que en realidad ocurría es que el mercado ayudaba a delimitar los espacios de acción legitima por parte del Estado a partir de un criterio natural y verdadero. Como hemos visto, el dispositivo liberal funcionaba de tal manera que, al denunciar la "falsedad” de ciertas medidas económicas, también evidenciaba su injusticia. Así, además de ser criticable por vulnerar los preceptos de la “ciencia” económica, la intervención del Estado en el mercado era indeseable porque corrompía los propios fundamentos de la organización política.

En este sentido, la legislación del Estado era un instrumento a la vez ilegitimo e ineficaz para el combate contra la pobreza. Ilegítimo porque amenazaba la libertad de los individuos expresada en el intercambio voluntario de propiedades mercantiles; ineficaz debido a que esa interferencia distorsionaba el equilibrio natural de los precios. La cuestión, entonces, pasaba por saber cómo hacerse cargo de este problema a través de un mecanismo que no atentara contra la libertad, pero que tampoco distorsionara el funcionamiento de las leyes del mercado. Ante ello sólo parecía existir una respuesta posible: la beneficencia

\footnotetext{
${ }^{347}$ Características que sí pertenecen a lo que nosotros llamamos dispositivo neoliberal del trabajo.
} 
privada. En efecto, si la legislación jurídica implicaba una coacción externa que siempre amenazaba la libertad, en cambio, la caridad provenía de los impulsos más profundos de cada ser humano.

Esta división resultaba fundamental para la coherencia interna del dispositivo liberal. Ya en 1839, el barón de Gérando escribía en La bienfasance pubblique que habría que distinguía entre dos tipos de derechos: unos que implicaban coerción del Estado y otros cuya obligación debía pertenecer al fuero interno de cada individuo. Como cabía esperar, la asistencia a los pobres formaba parte del segundo grupo, mientras que la salvaguarda de la libertad (moderna) y la propiedad (privada ilimitada) formaba parte del primero. Así, aunque los más desfavorecidos podían reclamar su derecho a una vida mejor, este último no podía tener obligatoriedad jurídica alguna. En realidad, como afirmaba el barón, el derecho de asistencia a los pobres no eran:

[...]de la misma naturaleza que el derecho a ver respetada la propia vida, la libertad personal, los bienes propios o el honor personal; sin ser menos sagrado, es, sin embargo, menos positivo, menos riguroso, menos absoluto. No se trata del derecho de petición, de exigir una prestación, de ejercitar una acción o de ver concedida esta o aquella ventaja: se trata de una esperanza legítima, de una recomendación poderosa, de una solicitud digna de la máxima atención. No es la reivindicación de una deuda; es la justa expectativa de un servicio.

Así, mientras que, por un lado, se encontraban las obligaciones jurídicas cuya esencia era positiva, rigurosa y absoluta; por el otro, se encontraban las obligaciones morales, igualmente sagradas, pero sin vinculación jurídica. Esta perspectiva también era compartida por Adolphe Thiers, ministro en el gobierno de Luis Felipe y responsable décadas más tarde de la represión a la Comuna de París, para quien la ayuda a los más desfavorecidos era la virtud más bella, siempre y cuando fuera asumida como un compromiso moral y no como una obligación del Estado:

La bienfaisance est assurément la plus belle, la plus attachante des vertus. De même que l'individu ne saurait trop s'y livrer, l’État non plus ne saurait trop la pratiquer. ${ }^{348}$

\footnotetext{
${ }^{348}$ Citado en: Ewald, François, L'Etat providence, Grasset, Paris, 1986, p.55. Aquí cabe recordar la tesis de François Ewald en el primer capítulo de su libro L'Etat providence. Según una lectura habitual en el marxismo, las nefastas consecuencias del laissez faire habrían obligado a los liberales a acudir a una instancia como la caridad para atender las nefastas consecuencias provocadas por este modelo. Sin embargo, Ewald critica esta postura e intenta mostrar el carácter productivo y coherente de la teoría liberal. En realidad, su defensa de la caridad no era un correctivo ante el fracaso del laissez faire, sino una consecuencia lógica de la separación entre derecho y moral efectuada por ellos.
} 
Así, mientras que unos derechos debían ser vinculantes para el Estado, las obligaciones de corte moral debían ser procesadas fuera del mismo so riesgo de violar la libertad y la propiedad. ${ }^{349}$ Sin embargo, precisamente porque la asistencia no podía ser vinculante en términos jurídicos, se presentaba como el único instrumento efectivo para unir a las distintas clases sociales. En efecto, la caridad no establecía una obligación externa impuesta coactivamente por el Estado, sino que suponía un compromiso libremente asumido gracias a una convicción personal. Al verse obligados por el Estado a ceder una parte de su propiedad legítimamente adquirida, los propietarios no podían sino de forma negativa, en cambio, la beneficencia ayudaba a despertar sus impulsos más solidarios. Así, donde "los caprichos de la fortuna” habían dividido a las personas por la desigualdad de bienes, la caridad reestablecía la armonía social mediante la generosidad de unos hombres completamente libres:

Entre les classes diverses de la société -afirmaba el ministro orleanista M.T. Dûchatel-, partagée par les caprices de la fortune avec une inégalité au premier abord si révoltante, la charité est le plus puissant médiateur ; elle rétablit l’harmonie, unit les riches et les pauvres, et change une odieuse supériorité en tutelle de protection et généreux appui. ${ }^{350}$

Y es que, para el dispositivo liberal, la beneficencia no ocupaba un lugar subordinado, tampoco funcionaba como una especie de compensación secundaría ante los posibles excesos del mercado. En realidad, los autores liberales del siglo XIX no imaginaban una comunidad donde todos los vínculos sociales fueran reducidos a la forma de los intercambios comerciales, más bien hacían descansar todo un proyecto de organización social sobre la distinción entre obligaciones morales y obligaciones jurídicas. De hecho, la oposición del liberalismo a los partidarios de la República democrática y social de 1848 -la llamada

\footnotetext{
${ }^{349}$ De hecho, la famosa división entre libertades positivas y libertades negativas de Isaiah Berlin, no es más que una reelaboración del argumento liberal que separaba estos dos tipos de obligación. En ambos casos, se trataba de impedir que el órgano jurídico político interviniera activamente en un terreno que supuestamente funcionaba mejor dejándolo al amparo de sus propios mecanismos internos. Sólo que mientras el liberalismo del siglo XIX vinculaba esta distinción, de forma más o menos explícita, a la existencia de una entidad natural como el mercado -al que se atribuía también el resguardo de la libertad y la propiedad-, Berlin presentaba su discurso como el resultado de una aparente fundamentación normativa.

${ }^{350}$ Citado en: Ewald...op,cit,p.58. Aquí vale la pena observar que, mientras el proyecto republicano fraternal apelaba al derecho para garantizar la igualdad jurídica de los hombres, y, con ello, acabar con la tutela que colocaba a la gran mayoría de los trabajadores en una condición de "minoría de edad”; el proyecto liberal apelaba a la caridad para reunir a las clases en relaciones de armonía fundadas en el tutelaje de unos sobre otros.
} 
Republica fraternal- no se explicaba tanto porque éstos defendieran la subordinación del individuo a la colectividad, sino por el hecho de que intentaban "restablecer la armonía" de la sociedad mediante los instrumentos coactivos del derecho.

Así, en un discurso titulado “Justice et Fraternité”, el economista liberal, Fréderic Bastiat, afirmaba:

Nous avons pour adversaires [...] les communistes, les fouriéristes, les owénistes, Gabet [sic.], L. Blanc, Proudhon, P. Leroux et bien d'autres [...] Je crois que ce qui nous sépare radicalement, c'est ceci : L'Economie politique conclut à ne demander A LA LOI que la Justice Universelle. Le socialisme, dans ses branches diverses, et par des applications dont le nombre est naturellement indéfini, demande de plus A LA LOI la réalisation du dogme de la Fraternité. ${ }^{351}$

Según el francés, el error que los “socialistas” habían mantenido desde los tiempos de Rousseau consistía en afirmar que todos los ámbitos del orden social podían ser sometidos a la “Ley”, incluyendo, desde luego, el “dogma de la fraternidad”. Ahora bien, como hemos visto, para los socialistas la “faternidad” tenía menos que ver con el deseo de imponer jurídicamente un sentimiento de solidaridad entre los hombres que con el intento de establecer restricciones al "imperio de la competencia ilimitada” mediante instrumentos jurídicos con el fin de hacer frente a la situación de miseria y explotación en que vivían las clases trabajadoras. En realidad, Bastiat tenía plena consciencia de que el centro del problema se localizaba en los límites de las atribuciones del derecho en su relación con la cuestión social:

La fraternité, en définitive, consiste à faire un sacrifice par autrui, à travailler pour autrui, Quand elle est libre, spontanée, volontaire, je la conçois, et j'y applaudis. J'admire d'autant plus le sacrifice qu'il est plus entier. Mais quand on pose au sein d'une société ce principe, que la fraternité sera imposée par la loi, c'est-à-diré, en bon français, que la répartition des fruits du travail sera faite législativement $(\mathrm{c} / \mathrm{n})[\ldots]$ une société peut exister ? ${ }^{352}$

Ahora bien, esta última afirmación no era una simple valoración personal de Bastiat, sino una conclusión que podía respaldarse “au nom de la sciencia”. En efecto, como afirmaba el francés, la “escuela de los economistas” no se oponía a la inclusión de la fraternidad en la "ley” porque estuviera a favor de una sociedad construida sobre las bases de "los intereses

\footnotetext{
${ }^{351}$ Bastiat, Fréderic, Euvres economiques, PUF, París, 1983,p. 110.

352 Ibid. p.114.
} 
privados”, ${ }^{353}$ sino porque la “ciencia económica” había demostrado la "falsedad” de esa doctrina. En realidad, si los autoproclamados liberales se oponían a establecer mecanismos jurídicos para mejorar las condiciones de vida de los más desfavorecidos, no era porque éstos fueran ajenos a los sentimientos de solidaridad entre los seres humanos, sino porque la ciencia mostraba la infertilidad de esta posición:

Nous aussi nous désirons voir les individus, les familles, les nations s'associer, s'entraider, s'entre secourir [...]. Nous aussi nous sentons battre notre cœur el couler nos larmes au récit des actions généreuses, soit quelques brillent dans la vie des simples citoyens, soit qu'elles rapprochent et confondent les classes diverses [...] nous combattons [a les socialistes] parce que nous tenons leurs idées pour fausses. ${ }^{354}$

Y en oposición a los “dogmas” fraternales, el conocimiento de la economía mostraba que la única forma de asistir a los más desfavorecidos pasaba, según Bastiat, por la multiplicación de los capitales. Como Smith, ${ }^{355}$ el economista francés pensaba que, gracias al libre mercado, los precios de los bienes de consumo tenderían a la baja, con lo cual la vida sería más barata y los salarios ascenderían por encima de lo requerido para satisfacer las necesidades. De este modo, el laissez faire se presentaba como el único "régimen de justicia verdadero", 356 un régimen tanto más exacto y eficaz, cuanto no se intentaba imponer políticamente mediante los instrumentos de la “Ley”.

Así, mientras el republicanismo social intentaba mostrar que "el imperio de la competencia ilimitada” generaba una situación de extrema injusticia para los obreros, la ciencia económica, según Bastiat, demostraba que ese imperio era el único régimen de justicia al que podían aspirar las clases trabajadoras. Refiriéndose a la libre competencia afirmaba:

[...] le résultat nécessaire de ce régime de justice exacte, et par conséquent de liberté et de sécurité, c'est de relever les classes souffrantes $[\ldots]^{357}$

\footnotetext{
353 Ibid.p.112.

354 Ibid.p.112.

355 Sólo que en un contexto en el cual Bastiat ya había sido testigo de las terribles consecuencias de la industrialización capitalista.

${ }^{356}$ Ibid.p.117.

357 Ibid.p.117.
} 
Alexis de Tocqueville recurrirá a una consideración semejante para rechazar la incorporación del derecho al trabajo en la constitución francesa de 1848. En su famoso discurso “contra el derecho al trabajo”, pronunciado en agosto de ese mismo año, quien fuera diputado de la II República en el momento de la represión de junio, ${ }^{358}$ reprochaba a la Comisión de Luxemburgo ${ }^{359}$ el haber confundido el papel de las obligaciones jurídicas con aquél que le correspondía a la caridad:

[...] la Commission se borne à imposer à la société le devoir de venir en aide, soit par le travail, soit par le secours proprement dit et dans les mesures de ses ressources, à toutes les misères; [...] l’État [...] a voulu accroître, consacrer, régulariser la charité publique. ${ }^{360}$

Sin embargo, al transgredir la línea que dividía las obligaciones jurídicas de las obligaciones morales no sólo peligraban instituciones como la propiedad privada y la libertad de los individuos, también se veía amenazado el funcionamiento del orden natural del mercado. Así, en su célebre discurso, Tocqueville se centraba en los dos escenarios económicos que la aprobación del derecho al trabajo podría traer consigo. En el primero de ellos, el Estado se vería obligado a ser un actor industrial para poder garantizar el trabajo de todos los ciudadanos, sin embargo, al hacerlo, terminaría por eliminar toda competencia convirtiéndose en “el propietario único de todas las cosas”:

[...] l'État entreprendra de donner à tous les travailleurs qui se présenteront à lui l'emploi qui leur manque, et alors il est entraîné peu à peu à se faire industriel ; et comme il est l'entrepreneur d'industrie qu'on rencontre partout, le seul qui ne puisse refuser le travail, et celui qui d'ordinaire impose la moindre tâche, il est invinciblement conduit à se faire le 'principal, et bientôt, en quelque sorte, l'unique entrepreneur de l'industrie. Une fois arrivé là, l'impôt n'est plus le moyen de faire fonctionner la machine du gouvernement, mais le grand moyen d'alimenter l'industrie. Accumulant ainsi dans ses mains tous les capitaux des particuliers, l'Etat devient enfin le propriétaire unique de toutes choses. ${ }^{361}$ '

La otra opción, igualmente execrable para Tocqueville, consistía en lo siguiente: en lugar de volverse un actor industrial, el Estado tendría que reglamentar el trabajo por encima

\footnotetext{
${ }^{358}$ En sus Souvenirs Tocqueville recordaba las jornadas de junio de 1848 como una confrontación lamentable pero "necesaria”, producto de las "falsas teorías" socialistas que enseñaban a los pobres una errada concepción del derecho según la cual "la desigualdad era moralmente condenable”. Cfr. Tocqueville, Alexis: Lettres choises. Souvenirs, Gallimard, Paris, 2003, p. 862ss.

359 Sobre la Comisión de Luxemburgo véase: Supra.pp.30ss.

360 Tocqueville, Alexis de, Contre le droit au travail, les belles lettres, Paris, 2015. p.36.

361 Ibid.p.37.
} 
de los imperativos de la competencia, sustituyendo así la capacidad del mercado para organizar el trabajo en función de las exigencias de la oferta y la demanda:

Si, au contraire, l’Etat veut échapper à la nécessité fatale dont je viens de parler, s'il veut, non plus par lui-même et par ses propres ressources, donne du travail à tous les ouvriers qui se présentent mais veiller à ce qu'ils en trouvent toujours chez il les particuliers, il est entraîné fatalement à tenter cette réglementation de l'industrie qu'adoptait, si je ne me trompe, dans son système, l'honorable préopinant. Il est obligé de faire en sorte qu'il n'y ait pas de chômage ; cela le mène forcément à distribuer les travailleurs de maniéré à ce qu'ils ne se fassent pas concurrence $(c / n)$, à régler les salaires, tantôt à modérer la production, tantôt à l'accélérer, en un mot, à le faire le grand et unique organisateur du travail. ${ }^{362}$

En el fondo, si la transgresión del límite entre las obligaciones jurídicas y las obligaciones morales resultaba denunciable, era porque amenazaba la naturaleza misma del orden económico. En efecto, la incorporación de un derecho al trabajo terminaría impidiendo que la demanda laboral se regulara a sí mismo por el único mecanismo efectivo: la competencia. En la misma línea de Bastiat, Tocqueville consideraba que la inserción de las demandas sociales al ámbito del derecho era lo que volvía tan peligrosos a los republicanos sociales. De ahí que la verdadera disyuntiva que el derecho al trabajo le presentaba a los miembros de la Asamblea no era otra sino la de definir si la Revolución de febrero había sido una Revolución socialista, en un sentido muy parecido al que Bastiat le daba a esta palabra:

On le dit, on le répète ; combien de fois, derrière les barricades de juin, n'ai-je point entendu sortir ce cri : vive la république démocratique et sociale ? [...] Nous avons besoin de savoir si la révolution de Février est une révolution socialiste. ${ }^{363}$

Ahora bien, además de considerar que el núcleo del socialismo consistía en supeditar el mercado a la "Ley”, Tocqueville identificaba un conjunto de características vinculadas a estas "falsas doctrinas”. El socialismo, afirmaba, estaba fundado sobre un ataque directo a los principios evidentes de la propiedad individual, ${ }^{364}$ pero también sobre “un prófond mepris pour l'individu pris en lui-même, à l'état d’homme”, ${ }^{365}$ una tentativa “variada, continua,

\footnotetext{
362 Ibid.p.37-38.

363 Tocqueville, Alexis, Contre...op.cit. p.39

${ }^{364}$ Un tipo de propiedad que, según Tocqueville, había existido desde los inicios de la humanidad hasta que el primer socialista dijo que "la propiedad es el origen de todos los males de este mundo". Como en el caso de Bastiat, Tocqueville aludía a Rousseau para localizar en él los inicios del socialismo.

365 Tocqueville, Alexis, Contre...op.cit. p.41.
} 
incesante”, por "mutilar” la libertad humana. En contraste, el mercado servía como un instrumento que ayudaba a garantizar la propiedad y a aumentar la libertad individual.

No obstante, la característica que más irritaba a Tocqueville del “socialismo” era su llamado constante a las pasiones materiales del hombre”, su insistencia excesiva por inclinaciones mundanas que, desde su perspectiva, no estaban a la altura de una verdadera Revolución:

Est-ce, [le droit au travail] comme on l'a prétendu tant de fois, la continuation, le complément légitime, le perfectionnement, de la révolution française ? est-ce, comme on l'a dit tant de fois, le complément, le développement naturel de la démocratie ? Non, messieurs ćest ni l'un ni l'autre ; rapellez-vous messieurs, la révolution française ; remontez à cette origine terrible et glorieuse de notre histoire moderne [...] Est-ce don en parlant [...] aux sentiments matériels, aux besoins matériels de l'homme, que la révolution française a fait les grandes choses qui l'ont illustré dans le monde ? Croyez-vous donc que c'est en parlant de salaire, de bien-être, de consommation illimitée, de satisfaction sans bornes des besoins physiques [...] Non, messieurs, non ; c'est en parlant de choses plus hautes et plus belles [...] c'est en parlant de vertu, de générosité, de désintéressément, de gloire, qu'elle a fait ces grandes choses ${ }^{366}$

Así, mientras los republicanos sociales interpretaban el derecho al trabajo como una herramienta para enfrentar la desigualdad social, Tocqueville consideraba que su imposición provocaría "une nouvelle formule de la servitude”: ${ }^{367}$ la de la "sociedad civil” al "Estado”. ${ }^{368}$ Ahora bien, si los ideales modernos se habían sostenido en la lucha contra todas las formas de dependencia vinculadas al Ancién Régime, el autor de La democracia en América podía establecer una línea de continuidad entre la negativa al derecho al trabajo y los ideales de la modernidad.

De ahí que, como la mayoría de la Asamblea, considerara que la inocultable miseria de Francia sólo podía ser eliminada mediante la asistencia” ${ }^{369}$ y a través de una constante modernización del ámbito económico. Así, en clara oposición a lo defendido por los partidarios de la República social, Tocqueville afirmaba que el verdadero logro de la Revolución francesa no pasaba por la construcción de un “poder social” capaz de reglamentar la esfera del trabajo, sino por la “inserción de la caridad en la política”:

\footnotetext{
366 Ibid.

367 Ibid.

368 Al respecto Tocqueville se valía de una metáfora peculiar: el problema no consistía en que el Estado fuera el director de la sociedad (directeur de la société), sino en que intentara ser el preceptor de cada hombre. (Cfr, Ibid.p.41.)

${ }^{369}$ De hecho, así fue como se incorporó a la constitución, una vez que se eliminó el derecho al trabajo se colocó, tal como defendía Tocqueville, el derecho a la asistencia. (Proudhon,...op.cit.p.191ss).
} 
Enfin, la révolution française a eu, la désir, et c'est ce desir qui la rendue non-seulement sacrée, mais sante aux yeux des peuples, elle a eu le désir d'introduire la charité dans la politique $\left[\ldots . .{ }^{370}\right.$

No existía ninguna contradicción en el hecho de que, por un lado, Tocqueville rechazara la intervención del gobierno en el mundo del trabajo, mientras que, por el otro, exigiera airadamente su responsabilidad para hacerse cargo de los más desfavorecidos mediante la implementación de instituciones dedicadas a la caridad. En el fondo, la participación del Estado era enteramente deseable siempre y cuando no amenazara con ocupar el lugar que la naturaleza había asignado a las dinámicas del mercado.

Más que defender un “Estado mínimo”, las tesis del autor de El Antiguo Régimen y la Revolución operaban sobre la distinción, establecida exitosamente apenas en el siglo XIX, entre las atribuciones políticas del gobierno y las necesidades objetivas del mercado. De ahí que, en el mismo discurso en el que Tocqueville arremetía contra el derecho al trabajo, propusiera la implementación de un “derecho de caridad”. Sin en el caso de un derecho de caridad la acción directa del Estado en favor de los más necesitados resultaba legítima, esto se debía a que dicha intervención, a diferencia del derecho al trabajo, sí respetaba el “orden natural” que la economía política había descubierto:

Il n'y a rien [dans le droit de la charité] qui donne aux travailleurs un droit sur l'État, il n'y a rien là qui force l'État à se mettre à la place de l'économie [...] il n'y a rien là qui autorise l'État à entremettre au milieu des industries, à leur imposer ses règlements [...] il n'y a là que du christianisme appliqué à la politique. ${ }^{371}$

Como señalaba Tocqueville, ahí no había intervención del Estado en la economía, sino cristianismo aplicado a la política. El discurso de Tocqueville evidenciaba las coordenadas de un nuevo horizonte político constituido gracias a la emergencia del liberalismo. En estricto sentido, el debate de la época no tenía lugar entre quienes pensaban que el mercado era capaz de arreglar todos los conflictos sociales y quienes pensaban que este debía ser suprimido en favor de un proyecto comunitario plenamente armónico, sino entre quienes estaban a favor de procesar los conflictos inherentes a las necesidades

\footnotetext{
${ }^{370}$ Ibid.p.56.

${ }^{371}$ Ibid.p.57
} 
materiales por la vía de las obligaciones jurídicas y quienes, por el contrario, optaban por el camino de las motivaciones morales. Aunque esta división parecía ser el resultado de una valoración estrictamente "filosófica”, ${ }^{372}$ en realidad, su condición de posibilidad era la construcción de esa rejilla de inteligibilidad llamada mercado. Sólo en tanto que este último fue problematizado como una instancia natural cuyo desenvolvimiento garantizaba el libre uso de la propiedad (privada ilimitada), Tocqueville pudo articular de forma coherente un discurso en el cual el procesamiento de las necesidades materiales por la vía de las obligaciones jurídica (derecho al trabajo) implicaba, al mismo tiempo, una tragedia económica y una amenaza política. ${ }^{373}$

Aunque en más de una ocasión sean presentados como los defensores del “liberalismo político”, si gente Constant, Guizot, Thiers o el propio Tocqueville se opusieron fervientemente a cualquier forma de organización laboral y al derecho al trabajo en nombre del libre uso de la propiedad (privada-ilimitada) fue precisamente porque antes habían adoptado una serie de convicciones de corte “económico”. Dado que para ellos el trabajo era una mercancía sujeta a las reglas del mercado, la organización de los trabajadores o la intervención del Estado destinada a garantizar un derecho al trabajo, implicaba, al mismo tiempo, una distorsión en la naturaleza de las cosas y una violación a la propiedad de las personas y a la libertad de los individuos. No importaba, sin embargo, que la preservación de esas libertades tuviera como correlato la perpetuación de unas relaciones de poder y dependencia que difícilmente hoy podríamos identificar, aunque sea de una manera remota, con el concepto de libertad.

Cuando en 1893 el ex-miembro de la Ligue pour la Liberté des Échanges y ferviente opositor a las alternativas “socialistas” durante la Revolución de 1848, Gustave de Molinari, escribía Les bourses de travail mantenía las líneas básicas de ese discurso económico-político que aquí hemos llamado dispositivo liberal. Rememorando la década de 1840, el francés

\footnotetext{
${ }^{372}$ En el sentido de que se presentaba como el resultado de un análisis de los fundamentos de la naturaleza de la sociedad.

${ }^{373}$ Ciertamente el francés se distinguía de otros autores más radicales afirmando que la caridad podía ser administrada por el Estado y no sólo por el sector privado, sin embargo, su planteamiento era enteramente coherente con las apuestas políticas que el dispositivo liberal había logrado presentar coherentemente como el horizonte de legitimidad y racionalidad propiamente moderno.
} 
denunciaba a quienes habían calumniado las bondades del "reino de la libertad ilimitada” afirmando que éste era lesivo para las clases trabajadoras:

Parmi les reproches que l'on a adressé à l'école économique dont nous avons l'honneur de soutenir et de propager les doctrines, le plus grave, c'est le reproche d'insensibilité à l'égard des classes laborieuses. On a prétendu même que l'application des doctrines de cette école. Serait funeste à la masse des travailleurs ; on a prétendu qu'il y a dans la liberté nous ne savons quel germe fatal d'inégalité et de privilège ; on a prétendu que si le règne de la liberté illimitée arrivait un jour, ce jour serait marqué par l'asservissement de la classe qui vit du travail de son intelligence et de ses bras, à celle qui vit du produit de ses termes ou de ses capitaux accumulés ; on a prétendu, pour tout dire, que ce noble règne de la liberté ne bourrait manquer d'engendrer une odieuse oppression ou une épouvantable anarchie. ${ }^{374}$

Así, como su defensa de la libertad de mercado se fundaba en una disciplina “científica” capaz de hablar en nombre de la "verdad”, Molinari podía rechazar alternativas de corte más bien social denominándolas “falaces” o “utópicas”. ${ }^{375}$ Como Malthus, Say, Tocqueville, Guizot o Bastiat, Molinari desacreditaba los “tristes sophismes” de los “adversaires de l'école libérale” en nombre de la ciencia. Inclusive si las denuncias de los propios trabajadores contradecían sus promesas, esta ciencia mostraba que la libertad de trabajo y la libertad industrial eran las únicas alternativas racionales para acabar con el sufrimiento de los más desfavorecidos y, al mismo tiempo, para garantizar la “igualdad y el orden” de la sociedad:

...les souffrances des classes laborieuses proviennent non point, comme ils pensent, de la liberté du travail, de la libre concurrence, mais des entraves de toute natures apportés à cette liberté féconde ; nous leur avons prouvé que la liberté n'engendre ni l'inégalité ni l'anarchie, mais qu'elle amène à sa suite, comme des conséquences inévitables, l'égalité et l’ordre. ${ }^{376}$

Como otros fragmentos que hemos citado, el texto de Molinar es revelador. Más allá de las teorías filosóficas fraguadas con posterioridad, las palabras de los autores de la época muestran que la especificidad del dispositivo liberal dependía de la conformación de un saber capaz de articular de manera coherente un discurso “verdadero” en el ámbito económico con

\footnotetext{
${ }^{374}$ Molinari, Gustave, Las bourses de travail, Gullaumin, Paris, 1893, p. 389.

${ }^{375}$ En el seminario de 1979 Michel Foucault comprende muy bien que la gubernamentalidad liberal se encuentra estrechamente vinculada a la emergencia de este espacio de veridicción que la economía política aísla. Sin él, el liberalismo del siglo XIX carecería de un apoyo en el ámbito del saber para legitimar sus objetivos y su peculiar forma de intervenir políticamente (Foucault, Michel, El nacimiento...op.cit. p. 28ss).

${ }^{376}$ Molinari...op.cit. p.391.
} 
las aspiraciones políticas de libertad, igualdad y propiedad que habían adquirido legitimidad en el seno de la modernidad. Sólo mediante esta articulación las terribles consecuencias de la incorporación del trabajo en las dinámicas de la competencia ilimitada, podían justificarse, a la vez, como el resultado de las exigencias naturales del mercado y como condiciones indispensables para el cumplimiento de las aspiraciones políticas modernas de libertad e igualdad.

En efecto, el liberalismo del siglo XIX no hubiera sido posible sin la apelación constante a una disciplina científica que veía en el mercado una entidad naturalmente regulada cuya consistencia interna dependía de la homologación del trabajo con los otros bienes mercantiles. Gracias a la aparición de este espacio conceptual resultaba posible distinguir entre un ámbito susceptible de regulaciones sociales a través de acciones “artificiales” y otro que obedecía a unas dinámicas naturales incompatibles con esa acción; pero también, gracias a ese espacio, se volvía plausible la incorporación de una segunda separación en el interior del dispositivo liberal, a saber: aquella que distinguía las obligaciones “jurídicas” de las “obligaciones morales”. En otras palabras: sólo porque la actividad laboral era interpretada como una mercancía más en el mecanismo natural del mercado se abría, por un lado, la posibilidad de desautorizar todo intento de regulación social a través de acciones jurídicas; mientras que, por el otro, se instaba a atender las consecuencias socialmente negativas que imponía el mercado apelando a una esfera como la caridad, puesto que su intervención no amenazaba el mecanismo natural de los precios.

Ahora bien, la afirmación de que el liberalismo decimonónico se sostenía en la separación entre el ámbito económico y las instituciones del Estado no resulta nada novedosa, ${ }^{377}$ sin embargo, es fundamental comprender que esa división no suponía cualquier

\footnotetext{
377 En su Filosofía del derecho Hegel había dado cuenta de este fenómeno con toda claridad. Con el concepto de "sociedad civil” Hegel se refería a esa “forma de sociabilidad” específicamente moderna en la cual las interacciones individuales se universalizaban gracias a la mediación de eso que los economistas clásicos llamaban mercado. Como éstos, el alemán constataba que la división social del trabajo favorecía el desarrollo de las necesidades y la sofisticación de los medios para satisfacerlas con lo cual los hombres se veían empujados a tejer vínculos de interdependencia cada vez más estrechos en un espacio ajeno al de la polis. Así, de forma semejante a Smith, el alemán mostraba que la generalización de este proceso daba pie a un mecanismo involuntario donde las relaciones reciprocas de los hombres se coordinaban en función de los intereses particulares. Sin embargo, la exposición de Hegel no dejaba lugar a dudas de que ese mecanismo sólo era posible sobre el fondo de un sistema normativo. Tanto la legitimidad de la propiedad de los individuos sobre aquello que intercambian, como la obligatoriedad de los acuerdos de esas transacciones a través de una figura contractual y la previsión de la violación de los mismos mediante la figura de la pena, eran condiciones jurídicas que el mercado presuponía para su propio funcionamiento. Así, lo que Hegel llamaba “derecho abstracto” era
} 
concepción del mercado. En efecto, tanto la reducción del sentido de la propiedad al de propiedad-privada-ilimitada, como la identificación de la facultad de trabajar con una mercancía determinada por el equilibrio natural de los precios, eran piezas sin las cuales esta concepción no habría podido operar con coherencia. Sin duda, los pensadores de los siglos XVI y XVII sabían que los bienes se intercambiaban en un espacio comercial atendiendo a regularidades más o menos precisas; no obstante, la idea de que el mercado funcionaba como un mecanismo natural que regulaba la interdependencia de todas las actividades

una precondición necesaria para el desarrollo de la "sociedad civil”. En todo caso, si la "sociedad civil” no se reducía a ese mecanismo autoregulado de intereses particulares, sus protagonistas no podían ser caracterizados como meros sujetos de necesidades, sino como personas jurídicas. En efecto, el funcionamiento del "sistema de las necesidades" estaba fundada en el reconocimiento jurídico de sus actores. De ahí que existiera una relación simétrica entre ampliación de ese sistema y la universalización del derecho: "La concepción de sociedad civil pertenece por otra parte al mundo moderno, que es el primero que hace justicia a todas las determinaciones de la idea”. (Hegel, G.W.F. Principios de la filosofía del derecho, Edhasa, Barcelona, 1999,p. 303). Hegel comprende como pocos que en el seno mismo de la modernidad yace una paradoja: es el reconocimiento de la individualidad en sus fines egoístas la que permite la universalización del derecho: "el fin egoísta [...] funda un sistema de dependencia multilateral por el cual la subsistencia, el bienestar y la existencia jurídica del particular se entrelazan con la subsistencia, el bienestar y el derecho de todos” (Hegel, 1999: 306). Ahora bien, si Hegel comprende bien que el mercado es concomitante al proceso de universalización de la personalidad jurídica, también entiende las limitaciones de ese proceso. En efecto, si la personalidad jurídica se universaliza gracias a los mecanismos de este sistema sólo lo hace considerando a los hombres como individuos propietarios que, mediante contratos, intercambian sus bienes para la satisfacción de sus necesidades egoístas. Por ello, a la constatación de que la "sociedad civil" es la antesala de la universalidad de la persona jurídica, añade que ese espacio de sociabilidad, circunscrito al mero interés personal, está atravesado de contradicciones que lo vuelven insuficiente para una realización plena de la libertad. La aparición de una masa de trabajadores dependientes y miserables es presentada por Hegel como la limitación principal de la "sociedad civil". A diferencia de Malthus o Ricardo, el alemán no explica la pobreza como una consecuencia inevitable de la evolución correlativa de la población y el mercado, sino, por el contrario, como una contradicción interna de esa sociedad civil abandonada enteramente a su propia dinámica. De esta forma, Hegel retrata con claridad el doble rostro de la sociedad civil: por un lado la modernidad ha desarrollado un espacio donde el individuo, además de realizarse como persona jurídica, hace progresar la industria y contribuye al desarrollo de la riqueza nacional; pero, por el otro, esa misma sociedad civil, volcada a la satisfacción del interés particular, explica la aparición de grandes masas de individuos pauperizados, entre las cuales la clase ligada al trabajo industrial llama especialmente la atención: "Cuando la sociedad civil funciona sin trabas, se produce dentro de ella el progreso de la población y de la industria. Con la universalización de la conexión entre los hombres, a causa de sus necesidades, y del modo en que se preparan y producen los medios para satisfacerlas, se acrecienta la acumulación de riqueza, pues de esta doble universalidad se extrae la máxima ganancia. Pero, por otro lado, se acrecienta también la singularización y limitación del trabajo particular, y con ello la dependencia y miseria de la clase ligada a este trabajo [...]la caída de una gran masa por debajo de un cierto nivel de subsistencia [...]lleva al surgimiento de una plebe que por su parte proporciona la mayor facilidad para que se concentren en pocas manos riquezas desproporcionadas” (Ibid.p. 359). En oposición a las posturas calificadas por el propio Hegel como liberales, el autor de la Fenomenología del espíritu aseguraba que estas contradicciones, inherentes al desarrollo de las sociedades modernas, no podían ser resueltas a través de los mecanismos internos de la sociedad civil. Sólo la mediación de instituciones públicas, cuyo funcionamiento no se limitaba a la satisfacción de los intereses individuales, podía superar las contradicciones impuestas por la propia dinámica de la modernidad. Así, la policía, las corporaciones, la burocracia, el parlamento y, finalmente, una monarquía sujeta a una constitución, se presentaban como instancias de mediación que permitían reconciliar los fines individuales de la "sociedad civil" con los objetivos políticos del Estado. 
económicas, ${ }^{378}$ incluyendo, desde luego, los intercambio de una propiedad mercantil como la facultad de trabajar, sólo fue problematizable a finales del siglo XVIII y durante todo el siglo XIX. ${ }^{379}$ Sin esta forma de problematización la articulación interna del dispositivo liberal -con la división entre las obligaciones jurídicas y las obligaciones morales, y la separación entre las actividades legítimas del Estado y aquellas que le estaban vedadas-, no podría haber sido planteada de forma coherente.

Quizás, a posteriori, el pensamiento político haya podido aislar un conjunto de rasgos característicos de las llamadas democracias liberales en los autores del siglo XIX. Sin embargo, la defensa de la libertad (moderna), la igualdad jurídica (sin fraternidad) y la propiedad (privada ilimitada), tan características del llamado liberalismo político, solamente pudieron ser pensadas en un discurso coherente cuando esa entidad natural y autorregulada llamada mercado fue concebida en el pensamiento moderno. Todavía más, el dispositivo liberal sólo pudo formularse cuando, en el espacio del saber, el mercado logró constituirse equiparando la dinámica interna de la esfera de la circulación de bienes y capitales, con la esfera, absolutamente novedosa, de la compra venta de trabajo.

\footnotetext{
${ }^{378}$ Sobre este punto en particular puede consultarse el interesante libro de Claude Roche Le connaissance et la loi dans la pensée économique libérale. El autor argumenta con detalle que el problema del mercado en el pensamiento liberal sólo fue posible cuando éste se concibió como la instancia donde se relacionaban todas las actividades económicas de una nación. Antes de ello se sabía con claridad que había espacios comerciales, pero no se habían aislado la ley que mostraba la interdependencia de esos espacios entre sí (Roche, Claude Le connaissance et la loi dans la pensée économique libérale, L'Harmattan, Paris, 1993).

${ }^{379}$ En general el marxismo no tuvo problemas en mostrar cómo la concepción liberal del mercado ocultaba que su propia condición de posibilidad era la mercantilización de la fuerza de trabajo -con todas las consecuencias que esto suponía-; sin embargo, algunos sectores de esta corriente tendieron a interpretar esta ausencia como la evidencia del carácter ideológico de una disciplina que debía ser contrarrestada mediante un discurso verdaderamente científico. (Cfr, Poulantzas, Nicos: Estado, poder y socialismo, Siglo XXI, México, 1979, p. 24.). Aunque esta perspectiva se sostenía en un diagnóstico correcto, impedía ver que el liberalismo no sólo era el reverso "falaz" de una ciencia verdadera (el materialismo histórico), sino un dispositivo en el que, de forma coherente, se vinculaban saberes con pretensiones de verdad y prácticas de poder que adquirían su legitimadas en esos saberes. A nuestro entender, si la justificación de esas formas de gobierno se sostenía en la articulación de un discurso en el que la naturaleza del mercado se emparentaba con las exigencias políticas de la modernidad, éstas últimas no debían ser interpretadas como recursos ideológicos que encubrían la dominación de clase, sino como piezas cuyo sentido dependía de la posición que ocupaban en el interior de un dispositivo. Sin duda, la primera de estas opciones favoreció toda una jerga de tópicos "marxistas" que han llegado hasta nuestros días. Así, para ciertos sectores de la izquierda más radical, entre la modernidad y el capitalismo no existiría ninguna diferencia; las aspiraciones de libertad, igualdad y propiedad serían reivindicaciones de clase; los mecanismos republicanos no serían más que ilusiones reformistas y el lenguaje jurídico un instrumento burgués. Aunque el pensamiento de Marx debe comprenderse en su oposición directa con el liberalismo decimonónico, como ha mostrado Carlos Fernández Liria y Luis Alegre Zahonero no es en estos tópicos donde encontraremos la fertilidad política de su trabajo.
} 


\section{Capítulo 3}

\section{Del trabajo como algo más que una mercancía al hombre-empresa}

Hacia finales del siglo XIX el dispositivo liberal comenzó a ser cuestionado a partir de varios frentes. Sin duda, el más importante de todos ellos era el encabezado por los propios trabajadores, quienes veían como se degradaba su existencia diariamente en las fábricas y los talleres. El crecimiento del movimiento obrero en países como Inglaterra, Francia o Alemania fue uno de los factores determinantes para que, poco a poco, emergiera una nueva forma de problematizar las relaciones que tenían lugar en el mundo laboral. Entre otras cosas, en Francia el miedo a que una política represiva atizara el fuego de una nueva rebelión, ${ }^{380}$ llevó al gobierno de la Tercera República a legalizar la asociación sindical. Así, en 1884, se derogó la famosa Ley Le Chapelier que, como vimos, impedía la asociación de trabajadores, para ser sustituida por una ley conocida como Waldeck Rousseau en cuyo artículo segundo se afirmaba:

Les syndicats ou associations professionnelles, même de plus de vingt personnes exerçant la même profession, des métiers similaires, ou des professions connexes concourant à l'établissement de produits déterminés, pourront se constituer librement sans l'autorisation du Gouvernement.

La legalización de los sindicatos implicaba un claro desplazamiento respecto al liberalismo más ortodoxo. Como hemos visto, los economistas consideraban a la organización obrera como una amenaza para la dinámica del mercado ya que terminaba por modificar los precios de esa mercancía llamada trabajo, con lo cual todo el mecanismo de autorregulación entre la producción y el consumo se veía afectado. Desde su perspectiva, la asociación concertada de los obreros les otorgaba una capacidad de negociación sobre el precio de los salarios tan disruptiva para el mercado que sus efectos podían compararse con aquellos que producían los monopolios sobre el precio natural de las cosas. De ahí que, como vimos, las luchas por la legalización de los derechos de asociación iniciadas en la década de

${ }^{380}$ Cfr. Palmer...op.cit. p.330. 
1830 no sólo fueran constantemente reprimidas sino combatidas en el terreno de las ideas por el discurso liberal.

No obstante, hacia 1880 las condiciones de Francia habían cambiado de forma importante. La guerra franco-prusiana terminó por sepultar el imperio de Napoleón III y el intento, en 1871, de establecer una Asamblea para normalizar la situación política finalizó con la revuelta de los "communards". Como había ocurrido en 1879 y en 1848, las reivindicaciones de los parisinos vinculaban la retórica republicana con la exigencia de mecanismos destinados a mejorar la situación de las clases trabajadoras. ${ }^{381}$ Aunque la Comuna de París fue duramente reprimida en pocos meses, su presencia marcó los derroteros de una Tercera República que intentó evitar a toda costa el desbordamiento violento de unas clases populares descontentas. De ahí que muy pronto, las dos demandas principales que habían articulado a los sectores de izquierda desde 1848 fueran incorporadas en la nueva República, a saber: el sufragio universal masculino y la legalización de la asociación de trabajadores. Es verdad que sólo fue tardíamente cuando el sindicalismo francés logró consolidarse como una fuerza política capaz de ejercer presión sobre las instituciones republicanas, sin embargo, su legalización mostraba hasta qué punto las coordenadas del tablero político comenzaban a desplazarse.

En todo caso, la experiencia francesa no era la única y mucho menos la más importante. Quince años antes -en 1869- el derecho de asociación había sido conquistado por los trabajadores de Alemania del Norte. ${ }^{382}$ Desde entonces, los obreros emprendieron un arduo trabajo de organización que derivó en la construcción de los dos primeros partidos de trabajadores en Europa: la Asociación Alemana de Trabajadores y el Partido Social Demócrata de Trabajadores (SPD). A pesar de que este último fue prohibido en 1878, su influencia no dejó de crecer durante las últimas dos décadas del siglo XIX. Gracias a una estrategia de "organización y formación de funcionarios obreros”, el SPD pudo presionar institucionalmente para obtener "concesiones de índole político-social” que mejoraron las condiciones de vida de los trabajadores, al tiempo que aumentaban su capacidad de maniobra. ${ }^{383}$

\footnotetext{
${ }^{381}$ Cfr. Ibid.p.331ss.

${ }^{382}$ Cfr., Abendroth, Wolfgang, Historia del movimiento obrero Europeo, Editorial Estelar, Barcelona, 1970, p.49ss.

${ }^{383}$ Ibid. 50
} 
Fue a raíz de las luchas contra la pretensión de eliminar el derecho de asociación por parte de los patrones de Hamburgo que se fundó la Comisión general de los sindicatos libres de Alemania, una organización centralizada que aglutinaba las luchas sindicales otrora desarticuladas. A partir de su nacimiento en 1890, el número de afiliados a los sindicatos socialdemócratas no dejó de aumentar: de 300 mil integrantes a principios de la última década del siglo XIX pasó a más de 2 millones en $1913 .{ }^{384}$ Alrededor de estos sindicatos se establecieron cooperativas, círculos culturales y clubs deportivos, al mismo tiempo, el Partido garantizaba asesoría jurídica para los obreros, promoción y distribución de periódicos, libros y revistas, cajas de ahorro, servicios funerarios, etc. ${ }^{385}$

El principal mecanismo para mejorar la situación de los trabajadores consistía en el establecimiento de "contratos tarifarios" definidos entre el sindicato y los empresarios. No obstante, cuando los trabajadores se enfrentaban a la negativa de estos últimos para modificar las condiciones de la negociación, no dudaron en utilizar de forma exitosa la huelga como un instrumento de presión. Gracias a la efectividad de esta medida, el sindicalismo alemán se convirtió muy pronto "en el ideal del movimiento obrero en los demás estados europeos”. 386

En cualquier caso, tanto en Alemania como en los distintos países en los que comenzó a crecer el sindicalismo, el instrumento de la huelga resultaba fundamental. No obstante, éste sólo era sostenible si las asociaciones de trabajadores contaban con "cajas de ahorro" también conocidas como "cajas de resistencia sindical”- a las que podían acudir para solventar la manutención de los trabajadores en los periodos de huelga. En efecto, enfrentar el aguijón de la falta de trabajo, ese que el "imperio de la competencia ilimitada" utilizaba para obligar a los individuos a aceptar sueldos de miseria, sólo era una opción viable cuando se contaba con recursos suficientes para poder subsistir en ausencia de un salario, recursos que sólo los sindicatos podían proveer.

En el fondo, la construcción de mecanismos como las “cajas de resistencia sindical” o la huelga requerían formas de organización necesariamente colectivas que eran enteramente

\footnotetext{
${ }^{384}$ Domènech, Antoni, El eclipse...op.cit.p.149.

385 Ibid.

${ }^{386}$ Abendroth, Wolfgang...op.cit..p.52. Es verdad que en los años del movimiento cartista los trabajadores ingleses habían sido la vanguardia de la lucha obrera y que hacia la década de 1880 hicieron suya la estrategia sindical, sin embargo, las restricciones de calificación laboral y de género heredadas de las jerarquías gremiales hicieron que las Trade Unions fueran menos inclusivas y, por los mismo, su crecimiento fuera menos acelerado. (Cfr,; , Domènech, Antoni, El eclipse...op.cit.p.153).
} 
antagónicas a la idea del empleo, como el resultado de un contrato entre particulares, que el liberalismo se había forjado durante buena parte del siglo XIX. ${ }^{387}$ Es claro que la asociación sindical servía como un instrumento de negociación de los trabajadores para obtener mejoras salariales, pero también promovía una red de protecciones sociales colectivas en el marco de un proyecto identitario común. Sin duda, en ambos casos el trabajo terminaba siendo concebido como “algo más que una mercancía”.

En el primer caso, la negociación colectiva implicaba que la definición de los contratos salariales no se limitaba a considerar "el precio del trabajo en el mercado”, sino que también debía considerar un conjunto de condiciones no mercantiles entre las cuales la mejora de las condiciones de vida de los trabajadores ocupaba un lugar de primer orden, pero también, y sobre todo, la capacidad organizativa de los mismos, sus estrategias de presión, sus métodos de resistencia, etc. En el segundo caso, la aceptación de que tanto los patrones como el propio Estado debían promover protecciones ante los múltiples riegos del centro de trabajo, evidenciaba que el trabajo asalariado no podía seguir siendo reducido a un mero contrato entre individuos libres en función de las prescripciones del mercado, sino que debía ser considerado como una relación social que traspasaba cualquier tipo de acuerdo entre particulares.

Ahora bien, la aparición misma de estos planteamientos en el seno del movimiento obrero era correlativa a un conjunto de desplazamientos que habían tenido lugar en el espacio del saber. Al menos desde la década de 1860 la coherencia interna del dispositivo liberal comenzó a ser impugnada desde distintos discursos. Aunque las críticas a los presupuestos del liberalismo provinieron de múltiples lugares y obedecieron a diferentes objetivos, aquí nos limitaremos a destacar las más representativas. Por un lado, la crítica de la economía política desarrollada por Marx mostraba que la compra de la mercancía trabajo no era la expresión de una transacción mercantil realizada en condiciones de libertad e igualdad, sino un proceso peculiar de apropiación de valor que perpetuaba formas de dominación y dependencia. Por su parte, la intervención de Durkheim en el dominio de la incipiente

\footnotetext{
387 De manera que la visión colectivista del movimiento obrero no se asentaba tanto en una especie de jerarquización a priori donde la libertad positiva se valorara más que la libertad negativa, sino a una urgencia de la realidad práctica. En realidad, la diferencia entre el liberalismo y el socialismo tenían menos que ver con la confrontación de dos visiones del mundo distintas que con estrategias de poder y resistencia contrapuestas en el marco de un contexto extremadamente singular.
} 
sociología ayudó a salir de la definición restrictiva del Estado establecida por el liberalismo para comenzar a otorgarle un papel activo en la esfera de lo social. De hecho, fue en ese contexto que la noción misma de derechos sociales comenzó a cobrar importancia con el fin de proveer una visión de la sociedad distinta tanto de la perspectiva liberal, en la cual los sujetos se adherían a lo social mediante contratos meramente individuales, como a algunos proyectos de corte anarquista o comunista, que apelaban al desmantelamiento de las instituciones estatales.

Así, cuando después de la Segunda Guerra Mundial la socialdemocracia europea, por una parte, logró generalizar la idea de que el trabajo debía ser comprendido, ante todo, como una actividad que permitía el acceso a los derechos sociales y el keynesianismo, por la otra,, propagó la convicción de que el Estado debía participar en la economía con el fin de garantizar el pleno empleo, retomaban la inercia de ese desplazamiento del dispositivo liberal iniciado a finales del siglo XIX. Esto, sin embargo, no implica que la perspectiva de Marx no tuviera enormes diferencias respecto a la de Keynes o que las reflexiones de Durkheim fueran el germen de la socialdemocracia europea, sino que, en ambos casos, aunque de maneras muy distintas, las apuestas que daban coherencia al liberalismo decimonónico habían sido desactivadas a través de un marco analítico que resultaba incompatible con aquellas.

Sin embargo, no pasará mucho tiempo para que las apuestas centrales del dispositivo liberal reaparezcan en el centro mismo de nuestro horizonte político. Desde la década de 1940 las líneas fundamentales que permitían el funcionamiento, más o menos coherente, del dispositivo liberal volverán a entretejerse en una realidad distinta, marcada por la tragedia de los totalitarismos y el ascenso del Estado Benefactor. Sólo que ahora el mercado no sólo será entendido como una esfera independiente del Estado, atravesada por una regularidad autónoma, sino como la matriz misma de un nuevo proyecto de reorganización social. Y el trabajador, ese sujeto sobre el que se articulaba todo el dispositivo liberal, no sólo será interpelado en tanto poseedor de una mercancía como las otras, sino como propietario de un activo enteramente peculiar, un activo sobre el cual puede y debe invertirse constantemente para obtener los mejores rendimientos, no sólo económicos sino también vitales. De esta forma, el neoliberalismo abrirá la era de la sociedad-mercado y del hombre-empresa. Veamos. 


\subsection{Desplazamientos del dispositivo liberal}

\section{Marx: El Capital como impugnación al dispositivo liberal}

Aunque el trabajo de Marx suele estar sujeto a múltiples niveles de análisis, El Capital puede ser leído como un intento de desactivar la relación entre saber y poder en la que se sostenía el discurso liberal decimonónico. En efecto, si el liberalismo podía reivindicarse a sí mismo como aquél horizonte de racionalidad en el que, gracias al libre desarrollo del mercado, podían realizarse los ideales modernos de libertad, igualdad y propiedad, era sólo porque ese planteamiento dejaba fuera todo un horizonte de problemas que la teoría de Marx, en cambio, sí permitía poner de relieve. Las lecturas más economicistas de El Capital suelen interpretar su contenido como una crítica peculiar a los fundamentos de la economía clásica, una crítica que, al mismo tiempo, permitiría avanzar hacia una refundación científica de esa disciplina. No obstante, al desvelar las insuficiencias del núcleo teórico que movilizaba a la economía política clásica -y, con ella, a los que el alemán llamaba economistas vulgares-, Marx también impugnaba aquel discurso que vinculaba el cumplimiento de los objetivos políticos de la modernidad con el funcionamiento del mercado

Contra las teorías de la economía clásica dominantes en la época y de las convicciones liberales que sólo eran posibles gracias a ellas, los análisis de Marx publicados en las décadas de 1860 y 1870 pretendían mostrar que la actividad laboral sólo podía ser reducida al papel de una mercancía partiendo de una confusión conceptual entre la noción de trabajo y la de fuerza de trabajo. Dicha confusión permitía que, en el interior de un complejo proceso económico-político, sustentado en la apropiación del plustrabajo por parte de toda una clase social, los ingentes beneficios del capital y las perniciosas condiciones de vida de los obreros, pudieran ser presentadas como el resultado de una lógica racional coherente con la libertad, la igualdad y la utilidad.

En efecto, en el El Capital Marx operaba un desplazamiento fundamental respecto a la economía política clásica. Aunque los análisis de Smith y Ricardo habían recurrido a la categoría de trabajo para dar cuenta de la fuente del valor, ambos autores terminaban desvinculando esa afirmación general de las consecuencias que debería traer consigo al momento de repensar el papel del salario en las sociedades modernas. Y es que, para ellos, el salario seguía siendo explicado en función de las fluctuaciones en el mercado como si se 
tratara de una mercancía semejante a cualquier otra. ${ }^{388}$ Será precisamente frente a esta concepción que el planteamiento mismo de Marx operará una verdadera revolución teórica. ${ }^{389}$

De hecho, el alemán será el único que, en ese contexto, logrará distinguir teóricamente entre el papel del trabajo en general, el papel del trabajo como productor de valor y,

${ }^{388}$ Es verdad que Smith había definido el valor de las mercancías por la "cantidad de trabajo que ella permite comprar", sin embargo, de inmediato relacionaba este valor con dos aspectos cualitativos inherentes al trabajo: la cualificación y la pena. Así, la diferencia en la calidad de los trabajos o el grado de "pena" invertido en ellos se conectaba inmediatamente con la variación en el precio del salario: "Si una clase de trabajo es más penosa que otra será también natural que se haga una cierta asignación a ese superior esfuerzo, y el producto de una hora de trabajo, en un caso, se cambiará frecuentemente por el producto de dos horas en otro". Smith, op.cit...p.47). Del mismo modo si una especie de trabajo requiere un grado extraordinario de destreza e ingenio, la estimación que los hombres hagan de sus aptitudes, dará al producto un valor superior al que corresponde al trabajo en él empleado. Al plantear las cosas de esta manera, el impacto de las diferencias cualitativas del trabajo respecto al valor de las mercancías terminaba resolviéndose en el terreno de las diferencias de salario sancionadas en el mercado por los mecanismos de la competencia. Esto implicaba que el análisis de los precios no podía sino presuponer, en todo momento, que el trabajo se encontraba afectado por el salario. En Las palabras y las cosas Foucault da cuenta de ello con claridad: "En el análisis de Adam Smith, el trabajo debe su privilegio al poder que se le había reconocido de establecer una medida constante entre los valores de las cosas; permitía equiparar en el cambio objetos necesarios cuyo peso y medida, por otra parte habían estado expuestos al cambio o sometidos a una relatividad esencial. Pero sólo pudo asumir tal papel al precio de una condición: era necesario suponer que la cantidad de trabajo indispensable para producir una cosa fuera igual a la cantidad de trabajo que esta cosa, a su vez, podía comprar en el proceso de cambio. Ahora bien, ¿cómo justificar esta identidad, cómo fundarla a no ser mediante una asimilación, admitida en la sombra más que aclarada, entre el trabajo como actividad de producción y el trabajo como mercancía que se puede vender y comprar?” Foucault, Michel, Las palabras...op.cit.p.248. Ciertamente Ricardo comenzaba criticando a Smith por las confusiones generadas en torno a la definición del valor, sin embargo, no tardaba en repetir la misma operación. En efecto, en la Sección uno del Capítulo 1 de los Principios de economía política y tributación, Ricardo defendía que el valor debe ser determinado exclusivamente por la cantidad necesaria de trabajo para la producción de una mercancía y no por el valor de los cereales o la variación del precio del salario, tal como Smith terminaba sugiriendo No obstante, cuando, en la Sección II, el inglés se preguntaba por el papel que juegan las diferencias cualitativas en la definición del valor señalaba lo siguiente: "La valuación de las distintas calidades de trabajo se ajusta rápidamente en el mercado para los fines prácticos y depende mucho de la destreza comparativa del trabajador así como del trabajo realizado. Una vez establecida esta escala, está sujeta a pocas variaciones. Si el trabajo diario de un joyero es más valioso que la labor diaria e un obrero común, ha sido ajustado desde hace mucho tiempo, y se la sitúa en su debida posición en la escala del valor”. De manera que Ricardo volvía a solucionar el problema de las diferencias cualitativas de trabajo remitiendo al equilibrio que el mercado generaba a largo plazo. Así, aunque el trabajo era entendido por él como medida del valor, ésta se hallaba en estrecha relación con la sanción de los mecanismos de la competencia. Semejante elección teórica condicionará el desarrollo posterior de la obra, a tal punto que en el Capítulo 5 de los Principios..., el inglés termina considerando el precio del trabajo en los términos de las fluctuaciones del salario en el mercado a partir de una base natural establecida por el costo de la subsistencia, tal como ocurriría con cualquier otra mercancía: "El precio del mercado de la mano de obra es el precio que realmente se paga por ella, debido al juego natural de la proporción que existe entre la oferta y la demanda; la mano de obra es costosa cuando escasea, y barata cuando abunda. Por más que el precio de mercado de la mano de obra se desvíe de su precio natural [equivalente al precio necesario que permite subsistir a los trabajadores] tiende, al igual que los bienes, a conformarse con él” (Ricardo...op.cit. p.72).

${ }^{389}$ Aunque en otros elementos su posición sea más controvertida Althusser tiene toda la razón al momento de calificar la ruptura de Marx respecto a la economía política clásica como una revolución teórica. Cfr. Althusser, Louis, Para leer el capital...op.cit. pp.87ss. 
finalmente, su función como parte de esa configuración más específica llamada salario. De ahí que, en primera instancia, el trabajo no remita a las fluctuaciones del mercado, sino a una actividad humana que adquirirá formas determinadas en función de las dinámicas sociales en las que se encuentre inscrito. Es eso lo que Marx intenta enfatizar tanto en el inicio de los Gründisse $e^{390}$ como en el capítulo V de El Capital donde establece la célebre distinción entre proceso de trabajo y proceso de valorización. ${ }^{391}$

En la Sección I de El Capital Marx intenta analizar el valor en términos teóricos como la racionalidad subyacente a las transacciones que tienen lugar en una sociedad de mercado, una sociedad donde la producción no tiene como finalidad el autoconsumo sino la incorporación a un proceso de intercambio generalizado. En ese marco analítico, el valor es definido en función del tiempo de trabajo socialmente necesario para generar una mercancía, no obstante, Marx deja bastante claro que en este momento del análisis la categoría de salario todavía permanece ausente, ${ }^{392} \mathrm{y}$, con ella, la especificidad del modo de producción capitalista.

En realidad, esta definición del valor debe ser entendida como si fuera anterior, en sentido lógico, ${ }^{393}$ a la determinación de los precios en el mercado capitalista. Una vez que la lógica mercantil aquí descrita sea estudiada en relación a la novedad que produce la existencia del salario, el análisis sufrirá serias modificaciones. De hecho, como hemos sugerido, en la exposición del primer apartado Marx parece referirse a una sociedad de mercado generalizado, donde los individuos intercambian libremente propiedades que son resultado de trabajos individuales e independientes. Es en ese escenario teórico donde supuestamente las mercancías deben intercambiarse en función del tiempo de trabajo socialmente necesario.

\footnotetext{
${ }^{390}$ Marx, Karl, Elementos Fundamentales para la Crítica de la Economía (Grundrisse) 1857-1858), SXXI, México, 2007,p.5ss.

${ }^{391}$ Marx, Karl, El Capital...op.cit.p.179ss. No obstante, las diferencias en las implicaciones que tiene el trabajo en la lógica mercantil y aquellas que tiene en la dinámica más específica del capitalismo serán resueltas de forma confusa por el autor abonando a largos debates teóricos.

${ }^{392}$ Ibid.p.55.

${ }^{393}$ Esto no se debe entender en los términos de la discusión clásica del marxismo, la cual tendía a dilucidar si existía una diferencia entre valor y el precio y si había una forma de lograr una reducción que mostrara cómo es que éste se define finalmente por aquél, sino en el sentido de que Marx expone en este momento una categoría más abstracta que responde a una elaboración conceptual lógicamente anterior a la definición de los precios en el mercado capitalista.
} 
Aunque Marx no logra aislar esta lógica mercantil plenamente para una exposición ordenada de manera satisfactoria en términos lógicos, ${ }^{394}$ sí hace explicito que la imposición del tiempo de trabajo necesario como "ley natural” supone la existencia de trabajos privados ejercidos independientemente en el marco de la división social del trabajo: ${ }^{395}$

Se requiere una producción de mercancías desarrollada de manera plena antes que brote, a partir de la experiencia misma, la comprensión científica de que los trabajos privados ejercidos independientemente los unos de los otros pero sujetos a una interdependencia multilateral en cuanto ramas de la división social del trabajo que se originan naturalmenteson reducidos en todo momento a su medida de proporción social porque en las relaciones de intercambio entre sus productos, fortuitas y siempre fluctuantes, el tiempo de trabajo socialmente necesario para la producción de los mismos se impone de modo irresistible como ley natural reguladora ${ }^{396}$

De tal suerte que la primera sección presenta un marco analítico donde la acción de múltiples productores independientes, intercambiando las propiedades resultantes de su trabajo, genera una regularidad -la del valor, entendido como tiempo de trabajo socialmente necesario- que se impone como si se tratara de una ley natural. Marx corona el análisis de esta sección mostrando que la generalización del mercado tiende a producir una mercancía peculiar que sirve como equivalente general: el dinero. Es este universo peculiar el que se encuentra dominado por eso que el alemán denomina “fetichismo de la mercancía”, esto es: por la apariencia de que los productores que intercambian su trabajo son en realidad cosas que se intercambian entre sí según un orden autónomo:

Si las mercancías pudieran hablar lo harían de esta manera: Puede ser que a los hombres les interese nuestro valor de uso. No nos incumbe en cuanto cosas. Lo que nos concierne en cuanto cosas en nuestro valor. Nuestro propio movimiento como cosas mercantiles lo demuestra. Únicamente nos vinculamos entre nosotras como valores de cambio. ${ }^{397}$

Si se observa con atención, este esquema es prácticamente idéntico a la imagen que el liberalismo se hacía del mercado: un espacio autorregulado que, mediante mecanismos naturales autónomos, asegura la equivalencia de los intercambios y, con ella, la igualdad de

\footnotetext{
${ }^{394} \mathrm{Al}$ respecto remito al lector al trabajo de Jacques Bidet: Bidet, Jacques, Refundación del marxismo. Explicación y reconstrucción de El Capital, LOM, Santiago de Chile, 2007.pp.66ss.

${ }^{395} \mathrm{Al}$ menos no lo hace hasta el Libro III, cuando ya se habla explícitamente del mercado capitalista.

${ }^{396}$ Ibid

${ }^{397}$ Marx, Ibid,p.101.
} 
sujetos considerados como propietarios libres. Ahora bien, todo el trabajo de Marx consistirá en mostrar que esa instancia autorregulada donde, supuestamente, individuos propietarios intercambian su trabajo en condiciones de igualdad, se disuelve por completo en el momento en que se analiza la verdadera especificidad del capitalismo. De ahí que, en la segunda sección del libro, el alemán caracterice irónicamente la representación de este espacio mercantil como el de un Edén de los derechos humanos en el que se cumplen las aspiraciones de libertad, igualdad y propiedad. Sin embargo, este paraíso liberal tendrá poco que ver con el mundo capitalista realmente existente:

La esfera de la circulación o del intercambio de mercancías, dentro de cuyos límites se efectúa la compra y le venta de la fuerza de trabajo, era, en realidad, un verdadero Edén de los derechos humanos. Lo que allí imperaba era la libertad, la igualdad, la propiedad y Bentham. ¡Libertad!, porque el comprador y el vendedor de una mercancía, por ejemplo, la fuerza de trabajo, sólo están determinados por su libre voluntad. Celebran su contrato de personas libres, jurídicamente iguales. El contrato es el resultado final en que sus voluntades confluyen en una voluntad colectiva común. ¡Igualdad!, porque sólo se relacionan entre sí en cuanto poseedores de mercancías e intercambian equivalente por equivalente. ¡Propiedad! Porque cada uno dispone sólo de lo suyo. ${ }^{398}$

Si el liberalismo fracasa en su explicación de la modernidad es en gran medida porque mantiene la comprensión del mundo mercantil provista teóricamente por la economía clásica, aun cuando, en los hechos, el mercado se encuentre atravesado por una variante que modifica totalmente el funcionamiento de sus mecanismos, a saber: la mercantilización de la fuerza de trabajo. Como los economistas y los autores liberales del siglo XIX comparten el supuesto de que el trabajo es una mercancía más cuyos procesos de intercambio se inscriben naturalmente en la dinámica del mercado son incapaces de analizar los efectos que el proceso de mercantilización del trabajo produce en la lógica mercantil. Marx, en cambio, tratará de mostrar que en realidad la emergencia de una mercancía como la fuerza de trabajo es el resultado de un proceso histórico de apropiación que modifica profundamente el funcionamiento del mercado tal como lo imaginaban los economistas de la época y, con ellos, los autores liberales.

En cierto sentido, Marx pretende mostrar que en un escenario donde el trabajo fuera una simple mercancía entre las otras, los beneficios del capital serían inexplicables porque la propia dinámica mercantil, atravesada por el aguijón de la competencia, obligaría a

\footnotetext{
${ }^{398}$ Ibid.p.214
} 
intercambiar equivalentes por equivalentes. De estas transacciones entre equivalentes nunca podría deducirse un aumento de valor como aquel que caracteriza la existencia misma del capital. Este impasse recorre toda la economía clásica y es imposible de solucionar desde el momento en que el trabajo es reducido al papel de una mercancía entre las otras.

En lugar de analizar las cosas de esta manera Marx afrontará el problema de la fuente de los beneficios del capital en términos del consumo de fuerza de trabajo en la esfera de la producción. ${ }^{399}$ No obstante, para ello será preciso que establezca una distinción entre la mercancía salario definida en función de su precio en el mercado y la capacidad productiva de la fuerza de trabajo. A partir de la segunda sección de El Capital la estructura mercantil va a ser analizada tomando en cuenta las transformaciones que genera la mercantilización del trabajo. Es importante tener claro que sólo a partir de esa sección Marx mostrará la especificidad del capitalismo respecto al esquema teórico de una sociedad puramente mercantil. En estricto sentido, esta sección define la forma en que la acumulación de dinero, presente en múltiples sociedades, es capaz de transformarse en acumulación de capital, exclusiva de la sociedad capitalista.

De entrada, el alemán distingue la circulación mercantil que funciona mediante la “conversión de mercancía en dinero y la reconversión del dinero en mercancía” (M-D-M) del modo de circulación capitalista cuyo movimiento es inverso: “conversión de dinero en mercancía y reconversión de mercancía en dinero” (D-M-D). Como afirma Marx, el dinero que en su movimiento se ajusta a ese último tipo de circulación, "se transforma en capital, deviene capital y es ya conforme a su determinación capital”. ${ }^{400}$ Sin embargo, este ciclo carecería de sentido si no hay un incremento en la cantidad de dinero puesto en marcha al inicio, por lo que D-M-D debe ser capaz de convertirse en D-M-D', donde D’ significa dinero incrementado. De manera que, formalmente, el capital no es otra cosa que el constante transitar de D a D’ a través de la compra de mercancías. ${ }^{401}$

\footnotetext{
399 De hecho, la llamada teoría del valor trabajo tiene toda su relevancia en este nivel teórico y no, como generalmente piensan los economistas, en su capacidad para definir los precios de equilibrio en el mercado. Dicho problema sólo se resolverá en el Libro III remitiendo a los costos de producción y a las dinámicas de competencia -tanto entre distintos ramos de la producción, como interior de cada ramo- una vez que se han asumido las consecuencias de la incorporación del trabajo como mercancía.

${ }^{400}$ Ibid,p.180

${ }^{401}$ De ahí que el impulso principal del capital no consista en adquirir objetos cualitativamente distintos, sino, en obtener una diferencia cuantitativa: "el proceso D-M-D no debe su contenido a ninguna diferencia cualitativa entre sus extremos, pues uno y otro son dinero, sino solamente a su diferencia cuantitativa. A la postre se sustrae a la circulación más dinero del que en un principio se arrojó a ella” (Marx, 2006: 184). En
} 


\section{Marx ilustra la abismal diferencia existente entre el ciclo M-D-M y ciclo-D-M-D'}

mostrando la profunda divergencia entre el capitalista y el "atesorador”. Lo que distingue a uno de otro no es la superioridad en el inconfesable deseo de enriquecimiento, ni la posesión de una ambición más sofisticada por parte de uno de ellos, sino el proceso del que son participes. Mientras el atesorador sustrae su riqueza de la circulación para mantenerla segura, el capitalista obtiene plusvalía por el hecho de relanzarla constantemente a la circulación:

Nunca, pues, debe considerarse el valor de uso como fin directo del capitalista. Tampoco la ganancia aislada, sino el movimiento infatigable de la obtención de ganancias. Este afán absoluto de enriquecimiento, esta apasionada cacería en pos del valor de cambio es comúna a capitalista y atesorador, pero mientras que el atesorador no es más que el capitalista insensato, el capitalista es el atesorador racional. La incesante ampliación del valor, a la que el atesorador persigue cuando procura salvar de la circulación al dinero, la alcanza el capitalista, más sagaz, lanzándolo a la circulación, una y otra vez ${ }^{402}$

cierto sentido, aquello que fundamentalmente se produce en el modo de producción capitalista no es éste o aquél tipo de mercancía sino plusvalorEn la forma de circulación mercantil -esto es en la forma que Marx sintetiza en el modelo M-D-M- los sujetos intercambian mercancías a cambio de dinero, el cual les sirve como medio de cambio para obtener una mercancía distinta a la que vendieron. Así, como puede observarse, el esquema M-D-M, sólo es posible cuando en los dos extremos del ciclo tenemos mercancías divergentes cualitativamente o, lo que es lo mismo, mercancías con valores de uso distintos. En cambio, en el ciclo D-MD' los portadores de dinero concurren en el mercado para comprar una mercancía, pero la compra de esa mercancía únicamente tiene sentido si es utilizada para obtener un incremento en el valor de cambio; es decir, para obtener plusvalor. Este punto resulta de suma importancia para la comprensión del análisis de Marx, en la medida en que el objetivo del capitalismo no consiste en generar valores de uso, sino en aumentar el plusvalor, el trabajo estará destinado a servir a las necesidades de acumulación capitalista y no a lasnecesidades sociales. Como señalan Jacques Bidet y Gérard Duménil, el trabajo en el sistema capitalista: "tiene por objeto la plusvalía, es decir, una riqueza abstracta indefinidamente acumulada, cualesquiera que sean sus consecuencias sobre los hombres, la cultura y la naturaleza” (Bidet, Jacques; Duménil, Gerard. Altermarxismo, El Viejo Topo, 2007, p.53).

402 Marx, 2006: 187. Así, se entiende con mayor claridad la fuerza de la crítica dirigida por Marx a la economía política clásica. Los economistas ingleses eran incapaces de comprender a cabalidad el funcionamiento del orden económico porque, como hemos visto, la clave que le da sentido a la sociedad capitalista es la existencia del plusvalor y, aunque es verdad que éste se hace presente en no es ahí donde termina por explicarse. Marx considera que la economía política clásica estaba destinada a fracasar una y otra vez en sus intentos de dar cuenta del orden económico si sólo se atenía a aquello que empíricamente se les presenta en el ámbito del mercado. Y esto es así porque justamente el fundamento de la sociedad capitalista no se encuentra en ese lugar. Desde Steuart la economía política había comprendido que el beneficio no podía explicarse como el producto del aumento de precios en el mercado; sin embargo, esta crítica no trajo consigo una problematización sobre origen del plusvalor. Por el contrario, la imposibilidad de deducir el incremento de valor del comercio llevó a los economistas a suponer que el valor de las mercancías es producto, a la vez, de la la renta de la tierra, del trabajo y del capital; pero al hacerlo se enfrentaban al problema de explicar cómo se asignaba la parte correspondiente del valor a cada elemento. En este sentido Althusser afirmaba que Marx inauguraba una ciencia, ya que el propio procedimiento de la economía política clásica hacia imposible que el plusvalor apareciera como objeto de estudio, mientras que Marx habilitará el aparato conceptual que vuelve posible su análisis (Althusser,Balibar, Para leer El Capital, SXXI, México, 2007, p.197). 
A primera vista el capital se presenta como un proceso en el que el dinero logra incrementar su valor por el simple hecho de ser "lanzado” a la circulación “una y otra vez”. Sin embargo es necesario explicar teóricamente este aumento de valor, lo cual implica no suponer una cualidad oculta del propio dinero capaz de dar cuenta de su incremento. ${ }^{403}$ En el apartado 2 de la segunda sección titulado "Compra y venta de la fuerza de trabajo" se hace patente que el plusvalor depende de la existencia de una mercancía específica llamada fuerza de trabajo. ${ }^{404}$ Una vez evidenciada la insuficiencia de todas las otras vías explicativas destinadas a dar cuenta del incremento dinerario (el paso de D a D’), la única opción posible es que el plusvalor dependa de la existencia de una mercancía que posea la extraña característica de generar más valor al momento de ser consumida que aquél que poseía al ser comprada:

[...] nuestro poseedor de dinero tendría que ser tan afortunado como para descubrir dentro de la esfera de la circulación, en el mercado, una mercancía cuyo valor de uso poseyera la peculiar propiedad de ser fuente de valor cuyo consumo efectivo mismo, pues, fuera objetivación de trabajo y por tanto creación de valor. Y el poseedor de dinero encuentra en el mercado esa mercancía específica: la capacidad de trabajo o fuerza de trabajo. ${ }^{405}$

\footnotetext{
403 De ahí la importancia teórica de que, en la primera sección, Marx definiera el dinero como equivalente general y no como una mercancía especial con propiedades intrínsecas capaces de explicar por sí mismas el aumento de dinero. La cuestión se vuelve más compleja porque Marx se empeña en desarrollar su argumentación sin transgredir la premisa de la economía política clásica según la cual en un mercado cuyo funcionamiento fuera adecuado las cosas se venderían y comprarían a su valor o, lo que es lo mismos, que en todo momento se intercambiaría equivalente por equivalente. Aquí Marx se enfrenta de lleno al problema del plusvalor. La economía política clásica había logrado eludirlo una y otra vez asumiendo que el beneficio era un resultado natural del adelanto de dinero, pero, como hemos dicho, Marx se niega a suponer que la apelación a las “cualidades ocultas" del mismo puede ser una respuesta satisfactoria. Además, el alemán se esfuerza en mostrar que incluso cuando el capital comercial y el capital usurero funcionan respondiendo al proceso D-MD' ninguno de los dos termina por explicar el origen lógico del plusvalor. En efecto, a pesar de que en los hechos podemos observar que individuos obtienen un incremento de valor comprando barato y vendiendo caro, es imposible suponer que en un mercado generalizado pudiera sostenerse enteramente de esa manera. Marx explica que en un sistema cuyo funcionamiento se sostuviera en semejante situación, aquél que vendiera las cosas sobre su valor, perdería lo ganado en el momento en que pasara a ser comprador ya que, también, tendría que comprar las mercancías por encima de su valor. Así, Marx hace patente que el análisis teórico nos obliga a asumir que el plusvalor no puede atribuirse al intercambio comercial de no equivalentes: "La transformación de dinero en capital ha de desarrollarse sobe la base de las leyes inmanentes del intercambio de mercancías, de tal modo que el intercambio de equivalentes sirva como punto de partida. Nuestro poseedor de dinero, que existe sólo como oruga de capitalista, tiene que comprar las mercancías a su valor, venderlas a su valor y, sin embargo, obtener al término del proceso más valor del que arrojó” (Marx, 2006:202).

404 En tanto que, desde un comienzo, Marx se ha negado a partir del supuesto de que el trabajo es inmediatamente definido en términos de trabajo asalariado, esta respuesta no lleva, necesariamente, al análisis de las condiciones sociales que hacen posible la aparición de la mercancía fuerza de trabajo. Sin embargo, Marx atiende este problema en un espacio teórico posterior, pues dicha pregunta no puede ser contestada desde el interior de la estructura capitalista, pues es, de hecho, su condición de posibilidad histórica.
}

${ }^{405}$ Marx, 2006:203 
Según Marx, la aparición del plusvalor sólo puede explicarse porque la fuerza de trabajo se compra a su precio en el mercado y no en relación con el valor que genera en la producción. Así Marx asume la definición del precio del salario establecida por los economistas liberales según la cual éste se establece en relación con el costo de los bienes necesarios para reproducir su subsistencia. No obstante, en El Capital muestra que en una jornada laboral dicha mercancía produce más valor del que le es remunerado por su salario. Ésta es, quizás, la tesis más conocida de Marx, sin embargo, suele pasarse por alto que su formulación supone una forma de problematización específica incompatible con el abordaje de la economía precedente. En efecto, en la compra de la fuerza de trabajo operan dos planos de realidad que la economía clásica no podía distinguir y que, finalmente, terminaba confundiendo: por un lado, la definición del salario en los términos sancionados por el mercado (costos de producción determinados relativamente por los mecanismos de la competencia), y, por el otro, los efectos del consumo de la fuerza de trabajo en la esfera de la producción, una vez que el trabajador se ve obligado a asistir al mercado a vender su única propiedad.

Aquí aparecen las consecuencias reales de haber comenzado por la llamada teoría del valor trabajo. De Smith a Say, la comprensión inmediata del trabajo como mercancía obligaba a confundir el precio asignado por el mercado en términos de salario con el consumo de la fuerza de trabajo. Sólo distinguiendo entre la sanción de los mecanismos mercantiles y el gasto de trabajo en la producción, es posible mostrar que la producción de la fuerza de trabajo no es equivalente al precio del salario. ${ }^{406}$ Sin embargo, es imposible llegar a esta conclusión mediante la peculiar forma de problematización que adopta la economía política clásica al identificar desde un inicio el trabajo con la mercancía fuerza de trabajo.

A partir de ahí el desarrollo de Marx es consistente con esa elección teórica. En la sección III, el alemán muestra que el valor de la mercancía - entendido como gasto de trabajo bajo condiciones sociales específicas y no como el precio en el mercado- se descompone en capital constante (c) -medios de producción-, capital variable (v) -salario- y plusvalía (pl) -

\footnotetext{
${ }^{406}$ Pero no sólo en el sentido "contable” de que el precio de la fuerza de trabajo en el mercado es menor al su valor en la producción, sino en el sentido de que no se encuentran en el mismo registro teórico. El precio de la fuerza de trabajo determina la asignación que el mercado hace de una mercancía según los mecanismos de la concurrencia y el costo de producción - en este caso de subsistencia-. En cambio, lo que el análisis del valor muestra es que toda mercancía es, en última instancia, el resultado de un consumo específico de trabajo en condiciones socialmente reguladas.
} 
sobre trabajo, o el excedente de trabajo respecto al salario-. Ahora bien, la relación $\mathrm{pl} / \mathrm{c}+\mathrm{v}$ constituye la "tasa de beneficios" del capital, mientras que la relación $\mathrm{pl} / \mathrm{v}$ la "tasa de explotación”. Al crecimiento de la tasa de explotación a través de la prolongación de la jornada de trabajo Marx lo denomina "plusvalía absoluta”.

Por su parte, la “plusvalía relativa” expresa la tendencia del capital a producir mercancía en un tiempo de trabajo menor. Esta tendencia se explica porque en cada ramo de la producción, los capitalistas se encuentran en competencia constante con otros capitalistas por lo que necesariamente deben aumentar su productividad para bajar el valor de las mercancías. De esta forma, Marx explica por qué el capital produce una revolución técnica permanente en la cual el aumento de plusvalor es correlativo a la disminución del valor de esa mercancía específica llamada salario. Esta tendencia del capital profundiza una división estructural que Marx identifica en términos de clases sociales, dicha división hace que los poseedores de medios de producción sistemáticamente obtengan sus beneficios apropiándose del trabajo de aquellos que se ven obligados a vender en el mercado su fuerza de trabajo.

De esta manera, Marx parte de la esfera mercantil que caracterizaba a la sección 1 para mostrar que, en circunstancias capitalistas, el funcionamiento del mercado se desarrolla bajo el fondo de la reproducción constante de una estructura de clase. Cuando, en el Libro III, el alemán vuelva a analizar la estructura mercantil lo hará asumiendo todas las implicaciones que trae consigo la apropiación del sobre trabajo por parte de una clase, apropiación que es el producto de la mercantilización de la fuerza de trabajo. Así, la Sección I del Libro 3 señala explícitamente este paso del análisis de las relaciones de clase al estudio del capitalismo tal como es percibido por los individuos. Marx intenta mostrar que entre los distintos ramos de la producción se establece una media de la tasa de beneficio debido a los mecanismos de la competencia. Dado que los capitalistas dirigirán su inversión a los ramos donde se genere más plusvalor, las mercancías que allí se venden tenderán a bajar su precio. Con lo cual, su precio no se define en función del tiempo de trabajo socialmente necesario, como se señala en la Sección I, sino a un precio que se acerca tendencialmente al precio de producción. Así, los precios de las mercancías se definen en torno a una tasa media de beneficios que, debido a los mecanismos de la competencia entre las ramas de la producción, tiende a bajar constantemente. 
En cualquier caso, Marx muestra que estos movimientos por los que se decide el precio en el mercado y la tasa de beneficios, operan siempre sobre el fondo una tasa de explotación que no es el resultad natural de los mecanismos del mercado, sino la consecuencia de incorporar al mercado el trabajo como una mercancía. Dicha incorporación, a su vez, es el resultado de procesos históricos vinculados a relaciones de poder, violencia y desposesión. Así, la narrativa del liberalismo es neutralizada en el lugar mismo que le otorgaba toda su coherencia: al mostrar que el mercado capitalista no era un mecanismo natural de distribución de los recursos en condiciones de igualdad e independencia, como imaginaban los economistas, sino un sistema que reproducía relaciones de clase producto de la venta, siempre desigual, de una mercancía artificial, Marx desautoriza la pretensión liberal de hallar en ese mercado el hilo de Ariadna que llevaría necesariamente a los parajes de la modernidad política, entendida como el espacio de realización de la libertad, la igualdad y la propiedad.

Aunque las múltiples interpretaciones de El Capital produjeron corrientes diversas e incluso confrontadas entre sí, la demostración sistemática de que la definición del salario no era el resultado de la naturaleza del mercado, sino de la organización específica de una sociedad de clases le permitió a buena parte del movimiento obrero justificar la legitimidad de sus luchas. Ahora, no sólo se trataba de pedir aumentos de salario en función de la caridad de los patrones o de su propia humanidad, tampoco se trataba de apelar a una instancia jurídica siempre sospechosa de violar la naturaleza del mercado, sino de mostrar que eran ellos quienes producían aquello que el propio mecanismo del capitalismo les arrebataba sistemáticamente.

\section{Durkheim en la Tercera República: solidaridad orgánica y técnica aseguradora}

Aunque en una corriente distinta a la abierta por Marx, la llamada escuela de "economía social” vinculada a los análisis de la emergente sociología, logró ganar terreno frente a la concepción liberal del trabajo durante la Tercera República francesa apelando al concepto de solidaridad y a un procedimiento denominado técnica aseguradora -el cual había sido aplicado con cierto éxito en la Alemania de Bismarck-. Mientras que para el liberalismo las relaciones laborales podían interpretarse como una mera ampliación de los contratos individuales en la esfera civil, la “economía social” se empeñaba en mostrar que la actividad 
laboral era parte de un conjunto de relaciones concernientes al Estado en tanto responsable de la normalidad del cuerpo social. ${ }^{407}$

A finales de ese mismo siglo Émile Durkheim daba cuenta de esta nueva consideración del Estado, en sus estudios sociológicos. En ellos el Estado aparecía como una institución vinculada a la evolución de las sociedades modernas cuya acción era consustancial a las dinámicas que tenían lugar en la esfera social. En la División del trabajo social, publicada en 1893 cuando la Tercera República ya contaba con dos décadas de existencia, Durkheim refutaba la idea de matriz contractual según la cual los ordenamientos sociales podían ser entendidos como el resultado de un acuerdo entre voluntades particulares ${ }^{408}$ e intentaba explicar las dinámicas de integración social echando mano de un concepto distinto: la solidaridad.

No obstante, el sociólogo francés distinguía entre una "solidaridad mecánica", característica de la antigüedad, donde la consciencia individual dependía de la colectividad y una "solidaridad orgánica", resultado de la división social del trabajo, donde la especialización de la actividad individual en la esfera laboral generaba lazos complejos que permitían el desarrollo de identidades plurales.

Según Durkheim, mientras que en la "solidaridad mecánica" primaba el "derecho represivo”, en la "solidaridad orgánica” lo hacía el “derecho cooperativo”. Esto era así porque, en las sociedades con una división del trabajo más desarrollada, los objetivos de los contratos entre individuos suponían la coordinación de funciones más complejas y diversas. Así, más que romper los lazos sociales generando una atomización individualista, la división del trabajo expresaba una forma de solidaridad más sofisticada y necesariamente más cooperativa pues debía integrar a individuos con identidades cada vez más heterogéneas en un mismo orden social.

Ahora bien, ocurría que en este tipo de sociedades las reglamentaciones jurídicas ocupaban un lugar preponderante. En un dialogo crítico con Spencer, Durkheim mostraba que el desarrollo de la división del trabajo no sólo le abría la puerta a la individualidad de los sujetos, sino que también generaba un aumento proporcional de los reglamentos del Estado

\footnotetext{
${ }^{407}$ Cfr. Donzelot, Jacques, La invención...op.cit. p.92ss.

408 "No solamente no hay sociedades que tengan origen tal, sino que ni siquiera las hay que puedan mostar en su estructura presente la menor señal de una organización contractual” Durkheim, Émile, La División del trabajo social, Cap.7
} 
que ayudaban a procesar las diferencias entre esos individuos. De ahí que esta participación estatal no significara necesariamente una restricción a la libertad individual, sino todo lo contrario: cuanto más compleja es una sociedad la cooperación de todos sus participantes implica una reglamentación mayor para coordinar actividades cada vez más diversas. De esta forma la "solidaridad orgánica” que caracteriza a sociedades con una división del trabajo desarrollada, se encontraba vinculada a un desarrollo de las atribuciones jurídicas de las instituciones. En ese sentido, las reglamentaciones que el Estado era encargado de tutelar debían ser concebidas como instancias necesarias para la integración de los individuos en sociedades complejas.

Sin embargo, Durkheim también era consciente de que la división del trabajo generaba formas patológicas que amenazaban la solidaridad, ${ }^{409}$ entre las cuales destacaban las crisis comerciales e industriales y el antagonismo entre capital y trabajo:

Un primer caso de este género [de anomias de la división del trabajo] lo proporcionan las crisis industriales o comerciales, con las quiebras que son otras tantas rupturas de la solidaridad orgánica; son testimonio, en efecto, de que, en ciertas partes del organismo, ciertas funciones no se ajustan unas a otras [...].

El antagonismo entre el trabajo y el capital es otro ejemplo más evidente del mismo problema. A medida que las funciones industriales se especializan, lejos de aumentar la solidaridad, la lucha se hace más viva. ${ }^{410}$

El sociólogo francés concordaba con los liberales en que la economía demostraba cómo los propios mecanismos del mercado eran capaces de reestablecer los equilibrios entre la producción y el consumo por sí mismos; sin embargo, añadía que esto ocurría después de perturbaciones prolongadas cuyos efectos ponían en riesgo la integración social. ${ }^{411}$ De igual forma, la división del trabajo generaba una especialización que derivaba en una separación cada vez más evidente entre los obreros y los patrones. Durkheim hacía notar que estas circunstancias iban acompañadas de una ausencia de reglamentaciones en el ámbito comercial y de un vacío jurídico inherente a los vínculos entre capital y trabajo:

Es verdad que los economistas demuestran que esta armonía se restablece por sí sola cuando ello es necesario, gracias a la elevación o a la baja de los precios que, según las necesidades,

\footnotetext{
${ }^{409}$ Cfr, Durkheim...ibid. Libro 3, Cap.1

410 Ibid.Cap.7

411 Ibid.
} 
estimula o contiene la producción. Pero, en todo caso, no se llega a restablecer sino después de alteraciones de equilibrio y de perturbaciones más o menos prolongadas. Por otra parte, esas perturbaciones son, naturalmente, tanto más frecuentes cuanto más especializadas son las funciones, pues, cuanto más compleja es una organización, más se hace sentir la necesidad de una amplia reglamentación.

Las relaciones del capital y del trabajo hasta ahora han permanecido en el mismo estado de indeterminación jurídica. El contrato de arrendamiento de servicios ocupa en nuestros códigos un espacio bien pequeño, sobre todo cuando se piensa en la diversidad y en la complejidad de las relaciones que está llamado a regular. Por lo demás, no es necesario insistir en una laguna que todos los pueblos actualmente reconocen y se esfuerzan en rellenar ${ }^{412}$

Esto, sin embargo, no llevaba a Durkheim a proponer una intervención del Estado para sustituir el papel que el mercado realizaba de forma deficiente -propuesta que, como vimos, el liberalismo acostumbraba atribuir a los socialistas-, sino que se limitaba a señalar que las patologías de la división social podían ser enfrentadas mediante formas de "solidaridad” modernas. Unas formas peculiares, pues, a diferencia del pasado, ya no se sustentaban en la conformación de identidades colectivas a través de un derecho de corte represivo, sino en la coordinación de los individuos a través de reglamentaciones jurídicas más bien cooperativas. Reglamentaciones que, en cualquier caso, sólo servían para atenuar la insoslayable conflictividad que el reconocimiento de identidades diversas producía, mas no para acabar con los efectos positivos de la división social del trabajo y, con ella, de los mecanismos de la competencia mercantil:

No cabe duda que, por precisa que sea una reglamentación, dejará siempre espacio libre para multitud de tiranteces. Pero no es ni necesario, ni incluso posible, que la vida social se deslice sin luchas. El papel de la solidaridad no es suprimir la concurrencia, sino moderarla. ${ }^{413}$

No obstante, la eficacia de todo este entramado únicamente podía ser sostenida a costa de mantener una ambigüedad teórica esencial en su concepción del trabajo. Al asumir como premisa de la ciencia económica que la actividad laboral era reductible a una simple mercancía, el problema cuantitativo de su precio en el mercado terminaba cualquier otra consideración sobre su carácter social.

Para los miembros de la Tercera República francesa el concepto de "solidaridad" otorgaba una vía de salida a los encarnizados debates entre liberales y socialistas. Atendiendo

\footnotetext{
412 Ibid.

413 Ibid.
} 
a esta noción, el Estado podía ser percibido como una instancia cuya labor consistía en restituir los lazos de integración ahí donde la división social del trabajo tenía un efecto anómico. Con lo cual, la separación, estrictamente liberal, entre un espacio político-civil susceptible de la participación del Estado y una esfera social sujeta a las dinámicas del mercado -o, en su defecto, a las de la caridad-, quedaba seriamente comprometida.

No obstante, la noción de un Estado garante de la solidaridad también se distanciaba de posiciones más radicales como las de los anarquistas y los socialistas -o, al menos, de la representación que se tenía de ellos en la época-. ${ }^{414}$ Mientras los primeros pugnaban por la eliminación del Estado, los segundos eran acusado de llamar a su conquista para extender sus funciones de forma ilimitada, hasta el punto de negar el espacio que la división del trabajo le había reservado a los mecanismos naturales del mercado. En un escenario semejante afirmaban sus críticos- sólo podían existir dos consecuencias: o el caos que advendría por la falta de un orden institucional o el despotismo de un Estado omnipotente que restringiría la libertad mercantil.

En cambio, al concebir al Estado desde el enfoque de la solidaridad, los partidarios de la III República podían asumir los efectos de la división social del trabajo como consecuencias necesarias de la evolución social, y, al mismo tiempo, enfrentar las patologías que emanaban de ese proceso. Así, la función del Estado no consistiría en tomar el lugar del mercado, sino en atenuar sus efectos negativos mediante la incorporación de reglamentaciones en el ámbito social. Sin embargo, faltaba saber si esta visión del Estado como instancia de restitución de la solidaridad podía ser aplicada en la práctica cotidiana, o si, como había ocurrido en 1848 con el concepto de fraternidad, terminar por disolverse ante la evidencia de la "lucha de clases".

Fue en torno al problema de los accidentes laborales que se encontró la respuesta a esta pregunta. En efecto, si desde la concepción liberal podía defenderse con cierto éxito que las relaciones contractuales tenían lugar entre individuos libres responsables de sí mismos, resultaba más difícil sostener que las consecuencias de un accidente ocurrido en la esfera laboral debían ser asumidas exclusivamente por el trabajador. ${ }^{415}$ Pero tampoco parecía

\footnotetext{
${ }^{414}$ Cfr, Donzelot, Jacques, La Invención...p.

${ }^{415}$ El tema de los accidentes laborales no era menor, representaba una de las principales preocupaciones de los trabajadores y uno de los motivos de conflicto más habituales. Y es que, la situación de vulnerabilidad en la que se encontraban los trabajadores fabriles en el siglo XIX era verdaderamente impactante. Por ejemplo, en
} 
recomendable dejar caer toda la carga de un accidente en la figura del patrón, ya que el pago de un accinte grave podía llevarlo a una situación económica tan comprometida que incluso llegaría a amenazar la estabilidad de un centro de trabajo del que otros obreros también dependían. No obstante, si se partía del concepto de solidaridad, podía asumirse que el trabajo era parte de un proceso global cuyo desarrollo era vital para el mantenimiento adecuado de la sociedad. De ahí se derivaba que, todo aquello que pusiera en riesgo la normalidad de sius procesos debía ser asumido como una responsabilidad social. ${ }^{416}$

Así, de la perspectiva que buscaba descargar los costos de los accidentes en una de las partes se pasaba a otro enfoque donde se asumía la existencia de riesgos inherentes a la esfera laboral. Ante esos riesgos no había que buscar a quien culpar sino cómo asegurar a los distintos actores de un proceso complejo, cuyos miembros, además, se hallaban constantemente amenazados. ${ }^{417}$ Ya en el gobierno de Bismarck se había ensayado una medida para hacer frente a estos problemas emulando los sistemas de seguros concernientes a los riesgos de las transacciones comerciales: el nombre de esta medida era "técnica aseguradora” y su implementación en el mundo del trabajo consistía en que “cada una de las partes hacia una especie de sacrificio previo a cambio de seguridad ante los problemas que pudieran surgir de un riesgo, el accidente”. ${ }^{418}$

Ahora bien, si el Estado era entendido como la instancia responsable de restituir los vínculos de solidaridad también debía tomar partido en este “sacrificio previo” aportando, junto con el obrero y el patrón, una cantidad de dinero para financiar y gestionar las instituciones de aseguramiento. Sin embargo, este "sacrificio" era recompensado con creces pues en el largo plazo prevenía al cuerpo social de situaciones anómicas y patológicas. Así,

uno de los reportes de los inspectores de fábricas ingleses con fecha del 31 de agosto de 1861 podía leerse lo siguiente: "Ruedas, cilindros, husos y lanzaderas son impulsados ahora con un potencial mayor y creciente; los dedos deben atrapar con más rapidez y seguridad la hebra rota porque si se los pone con vacilación o descuido se los sacrifica...Gran cantidad de accidentes se deben al ahínco de los obreros por ejecutar rápidamente su trabajo. Debe recordarse que para el fabricante es de máxima importancia que su maquinaria esté ininterrumpidamente en movimiento, esto es, produciendo hilado y tejido. Cada detención de un minuto no sólo significa una pérdida de fuerza motriz, sino de producción. De ahí que los capataces interesados en la cantidad de los artículos, acucien a los obreros para que mantengan la maquinaria en movimiento, y esto no es menos importante para los obreros a quienes se les paga por peso o por pieza" (Citado en Marx, Karl, El Capital...op.cit.p..

${ }^{416}$ Sobre la importancia del concepto de responsabilidad en la construcción del Estado Benefactor, véase Ewald, Francois,...op.cit.p. 55ss

${ }^{417}$ Donzelot, Jacques, La invención...op.cit.p.96.

${ }^{418}$ Ibid 
la conexión entre la teoría de la solidaridad y la técnica aseguradora permitía trasladarnos a una comprensión del trabajo ajena al imaginario liberal: ahí donde el liberalismo asumía que la relación obrero patronal era el resultado de un contrato jurídico entre individuos libres y propietarios, la perspectiva sociológica incluía esta relación en el funcionamiento de la totalidad social, de manera que la responsabilidad debía compartirse entre los miembros involucrados y el Estado como garante de la solidaridad.

Desde luego que esta perspectiva no podía parecer satisfactoria a los ojos de quienes apostaban por una revolución social, la cual estaba destinada a cortar de raíz el conflicto entre capital y trabajo, sin embargo, es posible comprender hasta qué punto implicaba un distanciamiento respecto a los presupuestos fundamentales que hacían funcionar al dispositivo liberal. Ciertamente, los individuos carentes de medios de producción permanecían subordinados a esa estructura que los obligaba a vender su fuerza de trabajo en el mercado, no obstante, el trabajo pasaba a ser “algo más” que una simple mercancía sujeta a la determinación de los precios en el mercado: ahora era concebida como parte esencial de una totalidad social cuyo funcionamiento adecuado debía ser protegido ante los riesgos que constantemente la acechaban.

Aunque de forma tardía este sistema de protecciones terminará por asociarse al lenguaje de los derechos y las garantías. En realidad, los primeros ensayos de esta amalgama no tendrán lugar en Europa occidental sino en Rusia y México como resultado de experiencias revolucionarias, en ambas experiencias el Estado adquirirá la obligación constitucional de asumir un conjunto de derechos sociales como su responsabilidad con resultados ciertamente ambiguos. ${ }^{419}$ Será la experiencia de la Segunda Guerra Mundial la que servirá de acicate para que los Estados europeos se comprometan por fin a implementar protecciones sociales en el marco de lo que se ha dado en llamar un Estado socialconstitucional.

De esta forma, la relación enteramente mercantil entre trabajador y patrón que dominaba la lógica liberal, no sólo será sustituida por un sistema de protección capaz de

\footnotetext{
${ }^{419}$ Aunque la constitución de la República de Weimar en 1919 y más tardíamente la Constitución de la República Española en 1931, plantearon objetivos semejantes, se trataba de proyectos demasiado fugaces que terminaron por dar paso a experiencias totalitarias bien conocidas Cfr. Pisarello, Gerardo, "El Estado social como Estado Constitucional: mejores garantías, más democracia”, en: Abramovich, V; Añon, M.J et.al (coomp.), Derechos sociales. Instrucciones de uso, Fontamara, México, 2006, p.26).
} 
asegurar a los trabajadores, sino que lo hará en términos de garantías jurídicas. Dichas garantías le otorgarán un estatuto a los trabajadores asalariados que los vincula con la condición de ciudadanos en tanto poseedores de derechos. Así, en unos cuantas décadas, la situación que imperó en el siglo XIX terminaba por invertirse completamente: si el dispositivo liberal funcionó negando la intervención jurídica en la esfera social, el funcionamiento de los Estados sociales europeos dependerá de su capacidad para vincular el mundo del trabajo al mundo de los derechos y las garantías, derechos y garantías que, a su vez, permitían el acceso a una ciudadanía plena. ${ }^{420}$

Si para el liberalismo no era evidente la contradicción existente entre sus pretensiones de libertad e igualdad y la ausencia de propiedad de un sector mayoritario de la sociedad, era sólo porque, como vimos, los obreros eran concebidos como propietarios de esa mercancía peculiar que era su fuerza de trabajo. Contra esta pretensión, cuya aparente evidencia sin embargo había permitido que el dispositivo liberal operara coherentemente, la noción de derechos sociales implicaba un cambio fundamental. En realidad, era precisamente porque los obreros se encontraban en una relación desigual con el empleador, reconocida en su ausencia de propiedad, que el Estado debía contribuir a hacer del trabajo un mecanismo de acceso al cumplimiento de las expectativas que antes eran exclusivas de los propietarios: salud, seguridad, vivienda, etc. ${ }^{421}$

Así, el reconocimiento de la situación de desigualdad y desventaja del trabajador respecto al patrón, llevó a implementar mecanismos construidos y respaldados socialmente que el mercado era incapaz de ofrecer. ${ }^{422}$ Tanto la llamada técnica aseguradora, como la comprensión solidaria del Estado y finalmente la noción misma de los derechos sociales, suponían una comprensión del trabajo que escapaba de la definición restrictiva en la que el liberalismo lo había circunscrito durante la mayor parte del siglo XIX. De esta forma, el trabajo había dejado se ser una mercancía más para convertirse en una relación que afectaba a todo el orden social y de la que su representante institucional -el Estado- debía responsabilizarse; una relación, finalmente, atravesada por derechos y garantías. que permitía el acceso a una ciudadanía plena.

\footnotetext{
${ }^{420}$ Cfr. Castel, Robert, La inseguridad social. ¿Qué es estar protegida?, Manantial, Buenos Aires $2015, p .42$. 421 Ibid.

422 Cfr. Castel, Robert, El ascenso....op.cit.p.35ss.
} 


\section{Keynes y el Estado interventor}

Ahora bien, el ascenso de los derechos sociales hubiera sido imposible sin la convicción de que el Estado podía y debía intervenir en el mercado sin que esto implicara una violación de las leyes constitutivas del ámbito económico. Fue sólo después de la crisis de 1929 y de la II Guerra Mundial que la convicción propiamente liberal según la cual el Estado no debía intervenir en el proceso económico comenzó a disolverse y, en buena medida, las ideas de John Maynard Keynes -ideas que, sin embargo, eran deudoras del ambiente intelectual de su época- fueron fundamentales para ello. En cualquier caso fue la Gran Depresión de 1929 la que sirvió de parteaguas para efectuar un importante desplazamiento respecto a los dogmas del pensamiento económico liberal.

En su Historia General del Siglo XX, el historiador italiano Giuliano Procacci señala que el desplome de la bolsa iniciado el 23 de octubre de 1929 provocó una depresión económica que, “con tiempos distintos y distinta intensidad, afectó a todos los países del planeta". ${ }^{423}$ Se trataba de una crisis de alcance global y cuyas consecuencias económicas y políticas no tenían precedente. Sin embargo, los efectos más inmediatos se vivieron en los Estados Unidos, una economía que había crecido de forma acelerada durante la década de 1920 debido a la demanda de bienes y servicios e de las naciones afectadas en la Primera Guerra Mundial. Una vez que estas naciones entraron en un proceso de recuperación se registró una sobreoferta en el sector agrícola y en el sector de materias primas que provocó una pequeña recesión hacia el año de $1927^{424}$ cuyos efectos terminarían por evidenciar una crisis estructural apenas un par de años después. ${ }^{425}$

Hacia 1932 el ingreso nacional en Estados Unidos había descendido a menos de la mitad del que existía en 1929 y se calcula que de 12 a 14 millones de personas se encontraban desempleadas. ${ }^{426}$ De igual forma, el nivel de consumo decayó debido a las pérdidas sufridas

\footnotetext{
${ }^{423}$ Procacci, Giuliano, Historia General del siglo XX, Crítica, Barcelona, 2005, p.155.

${ }^{424}$ Cfr, Cárdenas, Enrique, El largo curso de la economía mexicana, FCE, México, 2015, pp.404-405.

${ }^{425}$ La caída de la bolsa de 1929 mostró que la bonanza financiera de los Estados Unidos llegaba a su fin y, con ella, esos años de prosperidad que a través del cine de Hollywood habían cautivado al mundo y que Scott Fitzgerald había registrado en novelas como El gran Gatsby. Sobre la fascinación que el cine norteamericano había provocado en el mundo en esos años, véase: Wollen, Peter, El asalto a la nevera. Reflexiones sobre la cultura del siglo XX, Akal, Madrid, 2006, p..41ss.

${ }^{426}$ Cfr, Palmer, R \& Colton, J, Historia Contemporánea, Akal, Madrid, 1971, p. 552.
} 
por millones de ahorradores y la producción disminuyó drásticamente. Uno de los casos más relevantes fue el de la industria automotriz, emblema del auge económico norteamericano, cuya producción paso de 440.000 autos en agosto de 1929 a 92.500 en diciembre de ese mismo año.

Como suele suceder en estos casos, la crisis económica de Estados Unidos vino acompañada de un acelerado proceso de descomposición social evidenciado por el rápido aumento en las cifras de crimen y violencia. ${ }^{427}$ Con todo, el presidente Hoover se negaba a implementar medidas de intervención estatal a gran escala para hacer frente a la crisis. ${ }^{428}$ Es verdad que, finalmente, su administración tuvo que conceder ayuda financiera a bancos y ferrocarriles, estableciendo facilidades de crédito, al tiempo que liberaba las hipotecas de algunos granjeros y pequeños propietarios, ${ }^{429}$ sin embargo, las convicciones en materia de política económica vinculadas al dogmatismo dominante en ese momento le impidieron ir más allá. Para algunos especialistas, como Robert Skidelsky, la explicación de la gran depresión en términos exclusivamente monetaristas y no como un fallo en el mantenimiento de la demanda agregada, ${ }^{430}$ condicionó la acción del gobierno e impidió una salida más rápida de la crisis. ${ }^{431}$

Antes de la crisis del 29 Keynes ya se mostraba crítico ante las principales convicciones del pensamiento económico liberal, pero sobre todo ante los presupuestos filosófico-políticos en los que esta posición se sostenía. Así en un texto de 1926 caracterizaba, con evidente ironía, los supuestos de lo que él denominaba el principio de laissez faire:

\footnotetext{
${ }^{427}$ Sin mucho éxito, el entonces presidente Herbert Hoover intentó mitigar semejante problema mediante la creación de la Comisión Wickersham Los albores de los años 30 eran los tiempos de Al Capone y el subrepticio crecimiento de los gangsters, una época representada en el cine norteamericano con películas Scarface, esa obra magistral de Howar Hawk ambientada en las calles de Chicago donde, inevitablemente, la pobreza se mezclaba con la violencia. Al respecto véase: Rodenberg Hans-Peter, "El cine de gangsters y la depresión: Sacarface", en: Faulstich, Werner; Korte, Helmut (coomp.), Cien años de cine, 1925-1944, SXXI, México, 1995,p.155ss

${ }^{428}$ Cfr, Palmer...op.cit.p.553.

${ }^{429}$ Ibid.

${ }^{430}$ Cfr., Skidelsky, Robert, El regreso de Keynes, Crítica, Barcelona, 2009, p. 86ss.

${ }^{431}$ Uno de los principales detonadores de la crisis de 1929 fue el plan económico que se llevó a cabo en la Conferencia Monetaria Internacional de Génova, en 1922. Entre otras cosas dicho plan buscaba restaurar el patrón oro, impulsar la creación de bancos centrales independientes, imponer una férrea disciplina fiscal y condicionar la asistencia a los países marginales con el fin de equilibrar los mercados nacionales e internacionales. No obstante, la Gran Depresión obligaría a preguntarse si las principales convicciones del pensamiento económico seguían teniendo validez en un contexto tan adverso.
} 
[este principio] supone que por la acción de las leyes naturales los individuos que persiguen sus propios intereses con conocimiento de causa, en condiciones de libertad, tienden siempre a promover el interés general [...]. A la doctrina filosófica de que el gobierno no tiene derecho a intervenir, y a la doctrina divina de que no tiene necesidad de intervenir, se añade una prueba científica de que su interferencia es inconveniente [...]. El filósofo político podía retirarse en favor del hombre de negocios, porque el último podía alcanzar el sumum bonum sólo por perseguir su propio beneficio privado. ${ }^{432}$

Como pocos, Keynes captaba a la perfección que el liberalismo funcionaba como un dispositivo que se apoyaba en enunciados científicos y no como una simple teoría económica. Así, denunciaba la forma en que, tanto la idea de que la persecución de los fines individuales promovía el interés general como la doctrina "filosófica” que negaba al Estado el derecho a intervenir, entraban en relación mediante el asidero aparentemente "científico” que estas convicciones hallaban en ciertos enunciados de la disciplina económica. El interés de Keynes consistía en mostrar que esta articulación era insostenible dese el punto de vista de la doctrina económica. El fracaso de los intentos de salir de la crisis del 29 mediante políticas procíclicas en las cuales se privilegiaba el ahorro sobre la inversión pública, terminó por confirmar las intuiciones que Keynes había venido desarrollando desde la década de 1920. Así, en 1932, en el auge de la crisis económica, el economista inglés escribía:

Antiguamente no se consideraba adecuado que el Estado se endeudara para llevar a cabo otros gastos que no fueran los propios de la guerra, por lo que con frecuencia había que esperar a una guerra para poner fin a una depresión importante. Espero que en el futuro no mantengamos esa actitud financiera purista y que estemos dispuestos a gastar en empresas pacíficas lo que las máximas financieras del pasado sólo nos permitían gastar en la devastación de la guerra. ${ }^{433}$

Esta defensa del gasto público como vía para salir de la depresión se oponía directamente a la convicción de que, en el largo plazo, el mercado sería capaz de recuperar el equilibrio sin la necesidad de un agente externo que distorsionaría su funcionamiento. Keynes criticaba las medidas que buscaban disminuir la oferta y reducir los salarios para elevar los precios y reducir los costos, ya que, desde su perspectiva, eran incapaces de generar

\footnotetext{
${ }^{432}$ Citado en: Kicillof, Axel, Fundamentos de la Teoría General, Eudeba, Buenos Aires, 2007.

${ }^{433}$ Citado en: Novelo..op.cit.p.46.
} 
efectos visibles en un contexto de reducción del consumo presente o del consumo futuro expresado en términos de una imposibilidad de pagar los créditos. ${ }^{434}$

Como defenderá años después en su Teoría General, Keynes considera que si bien la inversión es el motor de la economía ésta no se incentiva propiamente por el bajo precio del dinero -como pensaba el pensamiento neoclásico- sino por el incremento de la demanda efectiva y agregada. ${ }^{435}$ De ahí que ninguna medida que quisiera reactivar la economía sería posible sin que se estableciera un ambiente proclive para el incremento del consumo y precisamente esto era lo que impedían las medidas procíclicas al obligar a los Estados a contraer el gasto público.

En buena medida, la política económica implementada a través del New Deal era deudora de las ideas que Keynes condensaría en la Teoría General. Cuando asumió el poder, Roosevelt echó a andar un potente proyecto de inversión pública financiando a los estados para la construcción de viviendas, carreteras y escuelas; de igual forma llevó a cabo un programa de obras federales y un programa de ayuda a granjeros, pequeños propietarios de casas y a gente de la industria. ${ }^{436}$ A contrapelo de lo que proponía el pensamiento económico ortodoxo el New Deal funcionó mediante una financiación por medio de déficit que, sin embargo, no culminó en una catástrofe económica sino en una exitosa vía de salida a la crisis económica iniciada en 1929.

La intervención de matriz keynesiana en el saber económica aunada al éxito del New Deal parecían poner fin a la hegemonía del dispositivo liberal. Durante las décadas siguientes, la articulación de un conjunto de saberes y prácticas que pretendían mostrar cómo el libre funcionamiento de las leyes naturales del mercado establecía las condiciones para el advenimiento de un crecimiento económico sostenido fundado en la libertad, la propiedad y la igualdad, fue sustituida por la convicción de que sólo mediante fuertes regulaciones e intervenciones del Estado, el mercado podía lograr estabilizar el desarrollo de sociedades en pleno crecimiento industrial. En este viraje, como vimos, el trabajo adquirió un papel fundamental: lejos de ser reducido al carácter de mercancía fue reconectado con la esfera

\footnotetext{
${ }^{434}$ Cfr. Solis, Leopoldo, La herencia intelectual de John Maynard Keynes, El Colegio Nacional, México, 1987, p. 58ss

${ }^{435}$ Cfr, Keynes, John Maynard, Teoría general de la ocupación, el interés y el dinero, FCE, México, 2014, p.54ss

${ }^{436}$ Cfr. Palmer...op.cit.p.553.
} 
jurídico política a través del lenguaje de los derechos sociales. Así, en un periodo de ascenso del capital vinculado con el aumento del consumo y la transferencia de valor de los países del Tercer Mundo, los Estados Nación europeos fueron capaces de construir un discurso en el que, no sin contratiempos, el trabajo pudo ser concebido como "algo más" que una mercancía, a saber: como una actividad que, además de proveer los recursos necesarios para sufragar las necesidades, garantizaba la ciudadanía en tanto soporte de derechos y permitía un conjunto de protecciones sociales absolutamente novedosas en la historia de la humanidad.

\section{2.- De cómo el siglo XX recuperó el dispositivo liberal}

Al final de El Antiguo Régimen y la Revolución, Tocqueville escribió un capítulo titulado “Cómo los franceses quisieron Reformas antes de querer libertades". En dicho texto, el filósofo hacía explícita una de las razones que, desde su perspectiva, explicaban el relativo fracaso de la Revolución francesa:

Es digno de ser destacado el hecho de que, entre todas las ideas y todos los sentimientos que prepararon el camino a la Revolución, la idea y el amor a la libertad pública propiamente dicha fueran los últimos en presentarse y los primeros en desaparecer. ${ }^{437}$

En efecto, si la Revolución francesa no había logrado hacer florecer una sociedad tan admirable como aquella que comenzaba a surgir en los Estados Unidos, se debía a que el amor por la libertad no había arraigado en el corazón de los revolucionarios franceses. Y es que, a diferencia de lo que había ocurrido en Inglaterra durante los siglos XVII y XVIII, estos últimos se sintieron menos atraídos por las dulces mieles de la libertad que por un deseo tan profundo de reinventar la sociedad que terminó produciendo unas consecuencias enteramente perniciosas.

El autor de La democracia en América creía encontrar el origen de esta desafortunada preferencia en los economistas franceses anteriores a la Revolución, quienes, embelesados con proyectos de reformas sociales y administrativas, ignoraron la importancia de las libertades políticas. Así, a pesar de haber sido partidarios del laissez faire, autores como

${ }^{437}$ Tocqueville, Alexis, El Antiguo Régimen y la Revolución, Alianza, Madrid, 2004, p. 191. 
Quesnay, Mercier de la Rivière o el propio Turgot, seguían siendo presos de una visión de la sociedad en la que el Estado mantenía un poder casi absoluto sobre sus súbditos.

Es verdad que esta caracterización de los fisiócratas no se alejaba mucho de la realidad, ${ }^{438}$ sin embargo, Tocqueville deseaba establecer una línea de continuidad entre ellos y las corrientes más nefastas de la Revolución de 1789, corrientes cuya influencia llegaría hasta ese año deplorable para Francia que fue 1848. Desde su perspectiva, el ala jacobina de la Revolución habría heredado de los economistas su desprecio por las libertades públicas y su afán por reformar la sociedad desde las instituciones del Estado. Antes de emancipar a los hombres para que lograran tomar sus propias decisiones en materia política, el Estado quería asegurar la igualdad de todos los seres humanos, incluso si para lograrlo requería violar los derechos más sagrados de los hombres. Según Tocqueville, el gran error que se le podía atribuir a los revolucionarios franceses era transparente: al priorizar el valor de la igualdad sobre la libertad habían sacado de cauce un acontecimiento político que en su origen no podía sino ser elogiado.

En la introducción del primer tomo de El Antiguo Régimen y la Revolución, Tocqueville prefiguraba la temática de los volúmenes que debían dar continuidad a su proyecto. Aunque finalmente nunca vieron la luz, estaba previsto que abordaran las causas que llevaron a la Revolución de 1789 a su estrepitoso fracaso:

[En los volúmenes siguientes] -aclaraba Tocqueville en la Introducción de la primera entregacomenzaré recorriendo esa primera época de 1789, en la que el amor a la igualdad y el amor a la libertad, se reparten su corazón; esa época en la que no sólo quieren fundar instituciones democráticas, sino instituciones libres; cuando no sólo anhelan destruir privilegios, sino reconocer y consagrar derechos [...] Siguiendo rápidamente el curso de esa revolución, trataré de exponer los acontecimientos, errores y desengaños que indujeron a esos mismos franceses a abandonar su primer objetivo y a desear sólo ser siervos iguales del amo del mundo olvidándose de la libertad. ${ }^{439}$

Tocqueville no sólo establecía una dicotomía entre un sector deseoso de “igualdad” radical y otro más inclinado hacia la "libertad”, sino que distinguía entre unas instituciones democráticas, por un lado, y unas instituciones libres, por el otro. A la soberanía popular defendida en su momento por Robespierre, la denominaba "sufragio de electores que no

\footnotetext{
438 Véase Infra,pp.96ss.

${ }^{439}$ Ibid.p.27
} 
pueden ilustrarse” y a la eliminación del sufragio censitario impuesta por el gobierno jacobino la caracterizaba como "el asentamiento de asambleas mudas y sojuzgadas". ${ }^{440}$ De esta forma, resultaba más o menos sencillo establecer una oposición simétrica entre unos revolucionarios radicales que encontrarían en el concepto de soberanía popular un pretexto para defender sus deseos de igualdad extrema y unos revolucionarios prudentes a los que se debían las conquistas más "preciosas y nobles” de 1789, a saber: "la libertad de pensar, de hablar y de escribir".

Sin embargo, el error de los jacobinos no era más que una simple extensión de la posición defendida por los economistas franceses unas décadas atrás. Cuando Turgot o Quesnay señalaron que el Estado no debía limitarse a gobernar la nación, sino que debía "moldearla”, en realidad, estaban colocando, tal como argumentaba Tocqueville, las bases de una nueva forma de tiranía, una tiranía que amenazaban la libertad de los hombres intentando imponer una sociedad igualitaria organizada enteramente por el Estado. Este sistema de gobierno, absolutamente pernicioso, no podía caracterizarse de otra manera más que como un "despotismo democrático”:

Esta forma particular de tiranía que se llama despotismo democrático, de la que la Edad Media no tenía idea, le es familiar a los economistas. No más jerarquías en la sociedad ni separación de clases, ni rangos fijos; sino un pueblo compuesto por individuos casi semejantes y enteramente iguales, esa masa confusa reconocida como el único soberano legítimo, pero cuidadosamente privada de todas las facultades que pudieran permitirle dirigir o incluso vigilar por sí misma su gobierno. ${ }^{441}$

¿Acaso no fueron los sans culottes los culpables de explotar esa idea según la cual las masas debían ser tratadas como la nobleza y la aristocracia?, ¿acaso no fueron los jacobinos quienes, para satisfacer estas exigencias igualitarias, dejaron atrás todos los instrumentos políticos necesarios para controlar a sus líderes? Tocqueville pensaba que sí. Sin embargo, este despotismo democrático no sólo había sido retomado por los jacobinos, sino que había llegado hasta el momento mismo en el que el francés escribía. Desde su perspectiva, los socialismos nacientes en la década de 1830 y aún vigentes hacía 1850, no eran sino una

\footnotetext{
${ }^{440}$ Ibid.

${ }^{441}$ Ibid.p.196.
} 
versión refinada de aquellas ideas fraguadas por los economistas franceses del siglo XVIII, aunque sin duda más peligrosa:

Se suele creer que las teorías destructivas con el nombre de socialismo son de origen reciente. Es un error, tales teorías son contemporáneas de los primeros economistas. Mientras éstos empleaban el gobierno omnipotente con el que soñaban cambiar la forma de la sociedad, los otros se apoderaban con la imaginación del mismo poder para destruir sus cimientos. ${ }^{442}$

De Quesnay a Louis Blanc, pasando por Robespierre o Saint Just, sólo había diferencias de matices: muy en el fondo, todos compartían el anhelo de una sociedad dirigida plenamente por el Estado. De esta forma, los distintos conflictos que habían tenido lugar en Francia desde finales del siglo XVIII podían ser vinculados gracias a una sencilla narrativa, una narrativa cuyo hilo conductor era el de una tensión entre la igualdad y la libertad. Sin duda, las diferentes circunstancias en las que se enmarcaba cada uno de estos conflictos debían ser tomadas en cuenta, sin embargo, en el fondo, era esta dicotomía la que explicaba el reparto de los papeles en las turbulencias del siglo XIX. Así, desde el jacobinismo revolucionario de 1789 hasta los defensores de la República social en 1848, pasando por los distintos movimientos asociacionistas en la década de 1830, se trataba de unos personajes que, llevando hasta el extremo sus demandas igualitarias, habían puesto en riesgo el más sagrado de los ideales modernos: el de la libertad.

Importaba poco que las distintas facciones revolucionarias hubieran apelado a la igualdad como una condición necesaria para poder ejercer la libertad política; importaba poco que para los revolucionarios de 1848 la idea de democracia supusiera la ampliación de los derechos políticos de todos y no sólo de una minoría; importaba poco que la exigencia de un derecho a la existencia, primero, y un derecho al trabajo, posteriormente, sólo fuera explicable en el marco de las relaciones de dependencia que vivían las y los trabajadores. Para Tocqueville, de lo que se trataba en todos esos casos, era de imponer una visión de la sociedad donde la igualdad tenía primacía sobre la libertad. Al plantear las cosas de esta manera, las motivaciones específicas de esos movimientos, las formas de articulación de sus demandas, la complejidad de sus discursos y la realidad material que los condicionaba, parecía reducirse a una disputa entre “ideales normativos” divergentes.

\footnotetext{
${ }^{442}$ Ibid.p.197.
} 
Por lo mismo, Tocqueville asumía que aquellos que se oponían a estas "teorías destructivas” -entre los cuales él ocupaba un importantísimo lugar- lo hacían, sobre todo, para resguardar las libertades públicas amenazadas por los socialistas. Esas libertades, sin embargo, no eran explicadas en el marco de las apuestas políticas a las que estaban vinculadas, ni en relación con los saberes que les daban coherencia, mucho menos con las prácticas de poder y dependencia a las que daban lugar... simplemente eran la representación de los valores más nobles y preciosos a los que la modernidad había dado lugar.

Sin ser consciente de ello, Tocqueville establecía las coordenadas de un tipo de narrativa que mostrará toda su fertilidad en el siglo XX. Además de establecer largas y cómodas continuidades, esta narrativa reducía la especificidad de las luchas sociales a una jerarquización divergente de los ideales políticos. De esta forma, la complejidad de las luchas políticas quedaba subsumida en una narrativa definida por antagonismos normativos simplificados. Algunos de los defensores más fervorosos del liberalismo en la primera mitad del siglo XX, así como algunos de los opositores más furibundos de las perspectivas socialistas no dejaran de sacar provecho de una explicación como ésta, ciertamente reduccionista pero efectiva.

Más de cien años después de la aparición de El Antiguo Régimen y la Revolución, Hannah Arendt ${ }^{443}$ intentará explicar el fracaso de la Revolución Francesa en unos términos muy parecidos a los de Tocqueville. Sólo que, para ella, el hundimiento de la Revolución no será el resultado del papel asignado a la igualdad, sino una consecuencia de haber priorizado la felicidad del pueblo y el deseo de atender sus exigencias materiales, por encima de la libertad humana:

No fue la conspiración de reyes y tiranos, sino la conspiración, mucho más poderosa, de la necesidad y la pobreza, la que distrajo los esfuerzos de los revolucionarios y evitó que "sonase la hora de la historia”. Mientras tanto, la Revolución había cambiado de dirección; ya no apuntaba a la libertad; su objetivo se había convertido en felicidad del pueblo. ${ }^{444}$

En efecto, en Sobre la Revolución Arendt recuperará la idea de Tocqueville según la cual una especie de "olvido de la libertad" fue el causante de los tropiezos revolucionarios,

443 De corte más bien republicano, aunque no de un republicanismo plebeyo o popular, sino más bien aristocrático, como ha señalado muy bien el propio Axel Honneth.

${ }^{444}$ Arendt, Hannah, Sobre la Revolución, Alianza, Madrid, 1998, p.80. 
sólo que, a diferencia del francés, la autora de La condición humana no buscará establecer una continuidad entre los economistas franceses y los socialistas de 1848, sino entre el gobierno jacobino de 1793 y la obra Marx, vinculando a este último con el destino de todas las revoluciones sociales del siglo XX:

La transformación de los Derechos del Hombre en derechos de los sans-culottes fue el momento crítico no sólo de la Revolución francesa, sino de todas las revoluciones que iban a seguirla. Esto se debe, en no escasa medida, al hecho de que Carlos Marx, el teórico más importante de todas las revoluciones, se interesó mucho más por la historia que por la política, $\mathrm{y}$, en consecuencia, desdeño casi por completo las intenciones que en principio animan al hombre de las revoluciones, la fundación de la libertad[...] En otras palabras, hubo de transcurrir casi medio siglo para que la transformación de los derechos del Hombre en derechos de los sans-culottes, la abdicación de la libertad ante el imperio de la necesidad, hallase su teórico. ${ }^{445}$

¿Acaso Marx no era el autor que había dado el cuerpo teórico más acabado a esta especie de prioridad de la carencia sobre la libertad?, ¿no era él quien, llamando a los pobres a cumplir las leyes necesarias de la historia mediante una revolución social, había llevado hasta el lugar de una teoría científica esta abdicación de la libertad? En realidad, las cosas estaban muy lejos de ser así; sin embargo, esta narrativa permitía que Arendt ofreciera una explicación coherente de los conflictos modernos en términos “filosóficos": cuando la necesidad de la historia o la resolución de las carencias materiales se superponen a los ideales de la libertad, esta última se halla destinada a perecer. Así, cualquier proyecto político contemporáneo que aspirara a tener legitimidad debía recuperar el valor de la libertad sobre las secuelas dejadas por "los derechos de los sans culottes” y la “teoría” revolucionaria de Marx.

Al final del capítulo titilado “La cuestión social”, Arendt intentaba mostrar que esta épica de la pobreza -la idea según la cual la resolución de las carencias de los desfavorecidos era el objeto fundamental de las luchas emancipatorias- explicaba que tanto en la Revolución de $1789^{446}$ como en todas las revoluciones posteriores la reivindicación de la libertad se hubiera vuelto secundaria. La autora de La condición humana intentaba mostrar que el cauce institucional y libertario que tomaron los movimientos revolucionarios en Norteamérica se

\footnotetext{
445 Ibid.p.81

${ }^{446}$ Cfr. Ibid.pp.147ss
} 
diferenciaba del cauce de la Revolución francesa precisamente por no haber sucumbido ante la seductora idea de que la lucha política contra las carencias representaba la expresión objetiva de la historia:

La necesidad en movimiento, la "tupida y enrome cadena que ciñe y amarra a la raza humana” y que "puede hacerse remontar hasta el origen del mundo”, brilló por su ausencia en la serie de experiencias de la Revolución y de la sociedad igualitaria de América [...] Pero lo cierto es que tras la creencia de Robespierre en la irresistibilidad de la violencia y tras la creencia de Hegel en la irresistibilidad de la necesidad [...] se alzaba la imagen de las calles de Paris durante la Revolución, la visión de los pobres que se movían a oleadas por las calles. ${ }^{447}$

La filosofía de Marx vendría a coronar este conjunto de ideas que, desde la Revolución, habían propagado la ilusoria idea una especie de necesidad en el devenir político de la historia. Al pensar que la pobreza podía combatirse políticamente -cosa que, según Arendt, resultaba falsa- de Robespierre a Marx se había terminado por dejar entrar una especie de determinismo político por la puerta trasera, un determinismo contraria a cualquier concepción verdaderamente relevante de la política entendida como el escenario de la libertad más plena:

[...] se ha debido únicamente a la tecnología y no al nacimiento de las ideas políticas modernas, la negación de la antigua y terrible verdad de que sólo la violencia y el gobierno sobre otros hombres podía liberar a unos cuantos. Hoy estamos en condiciones de afirmar que nada era tan inadecuado como intentar liberar a la humanidad de la pobreza por medios políticos (c/n); nada podía ser más inútil y peligroso [...] El resultado fue que la necesidad invadió el campo de la política, el único campo donde los hombres pueden ser auténticamente libres. ${ }^{448}$

Ahora bien, aunque las estrategias de Tocqueville y Arendt eran semejantes, sus rivales no eran ni remotamente los mismos. Entre la experiencia del francés y la experiencia de la filósofa alemana, había una realidad que no sólo había mostrado la ineficacia de un Estado activo, sino sus más execrables consecuencias. ¿No habían sido las promesas de poner fin al hambre y la pobreza, de garantizar la igualdad a toda costa, de asumir las leyes de la historia en ese camino de inobjetable necesidad, las que habían traído consigo regímenes totalitarios que anulaban toda forma de libertad? Sin duda estas eran algunas de las causas, sin embargo, como lo hizo Tocqueville en su momento, Arendt operaba a través de una

\footnotetext{
${ }^{447}$ Ibid.p.150.

${ }^{448}$ Ibid.151.
} 
proyección invertida: pintaba con el color de los totalitarismos toda la historia del siglo XIX, colocando tanto en Robespierre, como en los sans-culottes y, finalmente, en Marx, las semillas del stalinismo posterior.

Con todo, esta recuperación de la dicotomía entre libertad y necesidad, estaba montada sobre una concepción republicana donde la deliberación pública ocupaba un lugar fundamental. A través de una idealización de la Grecia Antigua, la autora de Eichmann en Jerusalén buscaba oponer la libertad, entendida sobre todo como acción política en el dominio de la esfera pública, a los determinismos que restringían dicha libertad en nombre de leyes objetivas o de la primacía de la esfera privada. De ahí que, aunque en muchos momentos elitista y aristocrática, su recuperación de la libertad no redundara en una reivindicación de las virtudes del mercado sobre las amenazas del Estado. Si es verdad que Arendt retomaba, en lo esencial, el modelo explicativo de Tocqueville oponiendo la libertad a unos proyectos igualitarios concebidos como expresiones de un determinismo histórico que había que desterrar, también lo es que ella desconfiaba por igual de las soluciones economicistas que veían en el mercado el modelo más cercano a las exigencias de un proyecto libertario.

\section{Hayek: un nuevo liberalismo}

No ocurrió así con otros opositores al socialismo que, siguiendo las líneas esbozadas por la narrativa de Tocqueville, intentaron reivindicar la primacía de la libertad sobre la igualdad o las necesidades materiales. En 1944, Friedrich Hayek publicó su famoso libro Caminos de servidumbre, una obra que lo llevaría a ser nombrado presidente de la Sociedad Mont Pèlerín y a granjearse el respeto de buena parte de los autores liberales de la época. Hayek planteaba su propia obra como un intento de recuperar la tradición liberal que, desde su perspectiva, se encontraba agonizando en la Europa de mediados del siglo XX. Para el economista austriaco los culpables de esa agonía eran fácilmente identificables: las políticas de planificación estatal y el marxismo en cualquiera de sus versiones, incluida la socialdemocracia.

De hecho, once años atrás de la publicación de Caminos de servidumbre Hayek había intentado mostrar que el emergente nacional socialismo alemán no era otra cosa sino la expresión de las ideas de corte marxista que desde hace años habían inundado el panorama alemán: 
La persecución de marxistas y de demócratas en general tiende a ocultar el hecho fundamental de que el nacional-socialismo es un verdadero movimiento socialista, cuyas ideas directrices son el fruto último de las tendencias antiliberales que han encontrado un terreno firme en Alemania... ${ }^{449}$

El desarrollo posterior del nazismo será interpretado por Hayek como una confirmación de los peligros inherentes a las ideas socialistas y un llamado urgente a recuperar la tradición liberal. Como hiciera Tocqueville un siglo atrás, la narrativa del austriaco partirá de una visión dicotómica en la cual el “olvido de la libertad” jugará un papel fundamental. Sin embargo, en su caso, será la pérdida de las “ideas esenciales” de la civilización europea encarnadas en la libertad económica, la que terminará por explicar el ascenso de los totalitarismos:

El punto decisivo, que las gentes apenas han reconocido todavía, no es ya la magnitud de los cambios ocurridos durante la última generación, sino el hecho de significar una alteración completa en el rumbo de nuestras ideas y nuestro orden social. Al menos durante los veinticinco años anteriores a la transformación del espectro del totalitarismo en una amenaza real, hemos estado alejándonos progresivamente de las ideas esenciales sobre las que se fundó la civilización europea. Que este movimiento, en el que entramos con tan grandes esperanzas y ambiciones, nos haya abocado al horror totalitario, ha sido un choque tan profundo para nuestra generación, que todavía rehúsa relacionar los dos hechos. Sin embargo, esta evolución no hace más que confirmar los avisos de los padres de la filosofía liberal que todavía profesamos. Hemos abandonado progresivamente aquella libertad en materia económica sin la cual jamás existió en el pasado libertad personal ni política. Aunque algunos de los mayores pensadores políticos del siglo XIX, como De Tocqueville y Lord Acton, nos advirtieron que socialismo significa esclavitud, hemos marchado constantemente en la dirección del socialismo. Y ahora, cuando vemos surgir ante nuestros ojos una nueva forma de esclavitud, hemos olvidado tan completamente la advertencia, que rara vez se nos ocurre relacionar las dos cosas. ${ }^{450}$

Allí donde Tocqueville había habilitado la oposición entre libertad e igualdad, Hayek hará aparecer una distinción tajante entre la “libertad espontánea”, ejemplificada por el funcionamiento del mercado, y la racionalización planificadora, vinculada a la intervención del Estado. Como los economistas del siglo XIX el austriaco señalará los peligros inherentes a la intervención del Estado en la economía, sólo que planteará esta amenaza como la de una

\footnotetext{
449 Citado en: Audier, Serge, Néo-liberalisme(s), une archéoogie intelectuelle, Bernard Grasset, Paris, 2012, p.216. La traducción es mía.

${ }^{450}$ Hayek, Friedrich, Caminos de servidumbre, Unión Editorial, Madrid, 2008. p.56.
} 
“racionalización” organizada desde el “Estado” en contra de la acción libre y espontánea de los individuos. De ahí que su defensa del mercado tuviera menos que ver con la creencia neoclásica de un equilibrio perfecto, que con lo que él denominaba "beneficios de la libertad”. ${ }^{451}$

En realidad, para Hayek, antes que otra cosa, el mercado era un sistema de información constituido espontáneamente por una multiplicidad de actores sociales. Intervenir en él no sólo significaba alterar la naturaleza de la economía, sino tratar de definir las decisiones libres que la gente tomaba al incorporarse en su dinámica. En el fondo, eso era lo que más le incomodaba, una vez que el Estado decidía la oferta de tal o cual producto terminaba decidiendo sobre sus gustos y, finalmente, sobre su libertad:

En una economía dirigida, donde la autoridad vigila los fines pretendidos, es seguro que ésta usaría sus poderes para fomentar algunos fines y para evitar la realización de otros. No nuestra propia opinión acerca de lo que nos debe agradar o desagradar, sino la de alguna otra persona, determinaría lo que hiciésemos. Y como la autoridad tendría poder para frustrar todos los esfuerzos encaminados a eludir su guía, casi con tanta eficacia intervendría en lo que consumimos como si directamente nos ordenase la forma de gastar nuestros ingresos. La voluntad oficial conformaría y «guiaría» nuestras vidas diarias. ${ }^{452}$

Esto no era la peor, la planificación estatal no sólo definiría nuestras elecciones en el consumo, sino también en la producción, con lo cual la asignación de los trabajos estaría controlada por el Estado llevando hasta el extremo la pérdida de nuestra individualidad:

No seremos ya libres para conducirnos racional y eficientemente tan sólo donde y cuando nos parezca oportuno, tendremos que ajustarnos todos a las normas que la autoridad planificadora deberá fijar para simplificar su tarea. Para poder desempeñar esta inmensa tarea tendrá que reducir la diversidad de las capacidades e inclinaciones humanas a unas cuantas categorías de unidades fácilmente intercambiables y deliberadamente despreciará las diferencias personales menores. ${ }^{453}$

Sin embargo, el hecho de que el mercado fuera interpretado como sistema de información producido por la actividad de todos sus participantes también quería decir que era imposible que un solo sujeto pudiera planificar conscientemente ese cúmulo de

\footnotetext{
${ }^{451}$ Lessnof, Michael...op.cit. p.174.

452 Hayek, ...op.cit. p.107.

453 Ibid.109
} 
información sin imponerse arbitrariamente sobre todos los individuos. Así, resultaba sencillo mostrar que cualquier intento de planificación en el mecanismo espontáneo del mercado terminaba por convertirse en un sistema dictatorial:

La mayoría de los planificadores que han considerado en serio los aspectos prácticos de su tarea apenas dudan que una economía dirigida tiene que marchar por líneas más o menos dictatoriales. Una consecuencia de las ideas que fundamentan la planificación central, demasiado evidente para no contar con el asentimiento general, es que el complejo sistema de actividades entrecruzadas, si va a ser dirigido en verdad conscientemente, tiene que serlo por un solo estado mayor de técnicos, y que la responsabilidad y el poder últimos tienen que estar en manos de un general en jefe, cuyas acciones no puedan estorbarse por procedimientos democráticos. ${ }^{454}$

Por lo mismo, Hayek concluía que dirigir la economía requería que el Estado interviniera a tal punto en las actividades de los individuos que no podía dejar espacio a la deliberación democrática. Así, con todas sus limitaciones, los sistemas regulados por la "libre espontaneidad" de los individuos eran totalmente preferibles a la "racionalización económica”, una “racionalización” que no podía sino negar la democracia y la libertad.

A diferencia de lo que ocurría con Tocqueville, cuyos adversarios eran los incipientes movimientos asociacionistas o un republicanismo social más bien desdibujado, Hayek hacia frente a realidades mucho más potentes y, desde su perspectiva, mucho más amenazantes: las políticas del New Deal implementadas por el Estado Norteamericano después de la crisis del 29, las teorías keynesianas que los Estados Nación comenzaban a aplicar en aras de garantizar el pleno empleo, la fuerza de poderosos sindicatos organizados desde principios de siglo y, sobre todo, la amenaza siempre latente del comunismo Soviético. Todos estos elementos eran interpretados por él como la expresión de la decadencia de nuestro tiempo, una decadencia tanto más peligrosa cuanto ponía en riesgo la libertad individual.

Así, frente a estas propuestas que ponían en riesgo la diversidad de los gustos y apelaban a la univocidad de una planificación centralizada, el mercado se presentaba como el ejemplo más palmario de la libertad, como el espacio donde las elecciones personales tenían pleno valor. Por ello, no resultaba inexplicable que el mercado y la democracia terminaran emparentándose en un mismo modelo educativo, ¿acaso el mejor sistema político no sería aquél en el que los individuos pudieran elegir libremente las opciones existentes?,

454 Ibid.p.101. 
¿acaso el funcionamiento del mercado, como un sistema organizado gracias a la actividad libre de los actores más diversos y ajeno a toda coacción, no debía servir como modelo para la organización de una sociedad democrática?, ¿acaso la aspiración de un régimen democracia no o consistía precisamente en garantizar la libertad y el respeto a la diversidad de los gustos y los deseos?, ¿no sería deseable que la sociedad tomara en su conjunto la forma misma del mercado? De hecho, esta posibilidad no dejará de rondar la cabeza de los autores que, ante el crecimiento de un Estado planificador, buscarán a toda costa recuperar el liberalismo perdido.

Es verdad que en la obra de Hayek pueden reconocerse sin dificultad algunas de las claves del dispositivo liberal del siglo XIX: la idea de que el mercado debía organizarse al margen de cualquier injerencia del Estado, la asunción de que la interferencia en la oferta de productos implicaba una amenaza contra la libertad de los actores mercantiles, la conexión entre un proyecto fundado en la libertad de mercado y unos ideales políticos que se asumían como la expresión de los anhelos de libertad modernos; sin embargo, los autores del siglo XIX nunca cruzaron el umbral que en la obra de Hayek había comenzado a abrirse como signo de los tiempos venideros. Al presentar al mercado como un sistema cuyo funcionamiento operaba en sí mismo de forma “democrática”, éste empezará a convertirse en el modelo organizativo al que deben aspirar todas las esferas sociales. ${ }^{455}$

$\mathrm{Y}$ es que de distintas maneras, tanto en su vertiente alemana como en su vertiente norteamericana, el neoliberalismo se caracterizará por hacer de los mecanismos del mercado criterios de verdad capaces de justificar la dirección de todos los ámbitos de la sociedad. ${ }^{456}$ A través de las publicaciones de gente como Walter Eucken, Franz Böhm, Müller Armack, Wilhelm Röpke, Rüstow, el propio Hayek y Von Mises en la revista Ordo, la reivindicación de un nuevo liberalismo adquirirá una influencia considerable en la reconstrucción económica y política de la Alemania de posguerra. A diferencia de la Escuela de Fráncfort,

\footnotetext{
${ }^{455}$ Cfr. Escalante, Fernando, Historia mínima del neoliberalismo, El Colegio de México, México, 2015.pp.33ss. Sólo en las coordenadas abiertas por este desplazamiento surgido en la década de 1940, era posible entender que varios años después un economista canadiense como Jean- Luc Migué pudiera siquiera plantear lo siguiente: "Una de las grandes contribuciones recientes del análisis económico ha consistido en aplicar íntegramente al sector doméstico el marco analítico reservado por tradición a la empresa y el consumidor. Al hacer de la pareja una unidad de producción en el mismo concepto que la empresa clásica, se descubre que sus fundamentos analíticos, son, de hecho, idénticos a los de ésta. ${ }^{455}$ El homo economicus se fusionaba a hora con el hombreempresa.

${ }^{456}$ Cfr, Castro Gómez, Santiago, Historia de..., op. cit. p.202ss.
} 
la llamada Escuela de Friburgo no se planteará el objetivo de criticar la irracionalidad inherente a las contradicciones del sistema capitalista, ni proponer un nuevo esquema de racionalidad social; por el contrario, la finalidad de su trabajo consistía en redefinir el Estado a partir de la racionalidad económica pues, desde su perspectiva, la instauración del nazismo en Alemania no fue el resultado lógico del desarrollo capitalista y de una economía liberalizada, sino el efecto de una liberalización insuficiente. A diferencia del liberalismo decimonónico, para los Ordo-liberales el mercado no sólo tiene que limitar al Estado, sino que debe ayudar a construirlo. En efecto, el Estado debe reformarse a partir de la economía de mercado. De esta forma, no sólo se tratará de contrarrestar los efectos negativos del poder estatal oponiéndole la libertad de mercado, sino de producir acciones gubernamentales directas a través de intervenciones reguladoras y ordenadoras -como las llama Eucken- para implementar esa libertad. ${ }^{457}$

Por su parte la corriente neoliberal que surgirá en la Escuela de Chicago comandada por Milton Friedman, también se opondrá a aquellas corrientes que, para ellos, representan la amenaza de nuevas formas de totalitarismo; a saber, las políticas del New Deal, la economía planificada, el socialismo soviético y las ideas keynesianas. Sin embargo, su objetivo no será ya el de limitar la ilegítima intervención del poder soberano sobre el espacio que "narturalmente" le corresponde al mercado, ni reconstruir el Estado a partir de este último, sino implantar un nuevo modelo de gobierno a todos los ámbitos de la realidad; se tratará, pues, de incorporar el modelo empresa a todos los sectores sociales, incluso a aquellos que, hasta entonces, no se hallaban incluidos en la lógica del mercado. En el fondo, su finalidad no será otra sino hacer del gobierno una actividad que se desarrollará bajo los criterios del modelo empresarial a través de su intervención en todos los ámbitos de realidad. En palabras de Michel Foucault:

El neoliberalismo norteamericano pretende ampliar la racionalidad del mercado, los esquemas de análisis que dicha racionalidad presenta, y los criterios de decisión que ésta

\footnotetext{
457 Thomas Lemke resume bien este punto en su ensayo "Birth of Biopolitic": "Whereas in the eighteenth century the problem liberals addressed was how to limit an extant state and establish economic liberty within it, in Germany after 1945 the problem was the opposite: how to create a state that did not yet exist on the basis of a non-state domain of economic libertyLemke, Thomas, Economy and Society, Volume 30, Number 2, May 2001: 190-207.
} 
implica, a ámbitos no exclusiva ni predominantemente económicos: la familia y la natalidad, pero también la delincuencia y la política penal. ${ }^{458}$

Así, si el liberalismo del siglo XIX había pensado al mercado como un límite para las atribuciones del Estado, el neoliberalismo norteamericano del siglo XX lo convertirá en el dominio que, a través del modelo empresa, define los parámetros de la nueva organización social y de la nueva subjetividad que se le exige a los individuos. Sin embargo, como puede sospecharse, la pretensión de implantar el modelo empresa a todos los sectores de la sociedad requerirá que tanto la concepción del hombre, como la de la misma sociedad sean redefinidas. En ese sentido, el neoliberalismo norteamericano no se limitará a ser una corriente económica, sino que abrirá el camino para una visión sociológica y antropológica renovadas del ser humano, tal como lo señala Thomas Lemke:

Whereas the Ordo-liberals in West Germany pursued the idea of governing society in the name of the economy, the US neo-liberals attempt to re-define the social sphere as a form of the economic domain. The model of rational-economic action serves as a principle for justifying and limiting governmental action, in which context government itself becomes a sort of enterprise whose task it is to universalize competition and invent market-shaped systems of action for individuals, groups and institutions” This strategic operation relies on a prior epistemological shift which systematically and comprehensively expands the object addressed by the economy. Here, the economy is no longer one social domain among others with its own intrinsic rationality, laws and instruments. Instead, the area covered by the economy embraces the entirety of human action to the extent that this is characterized by the allocation of scant resources for competing goals. The neoliberals are interested in ascertaining what reasoning it is which persuades individuals to allocate their scant means to one goal rather than to another. The focus is therefore no longer on reconstructing a (mechanical) logic, but on analyzing a form of human action governed by a specific, unique (economic) rationality. From this angle, the economic is not a firmly outlined and delineated area of human existence, but essentially includes all forms of human actions and behavior

Será en ese nuevo espacio del saber, donde converge la economía, la sociología y la antropología, que los nuevos discursos sobre el trabajo encontrarán un campo fértil. ${ }^{459}$ Ahí, en esta rehabilitación del liberalismo decimonónico, el trabajo volverá a aparecer como una actividad enteramente circunscrita a su carácter mercantil, sólo que ahora toda una serie de saberes novedosos, imposibles de pensar en el siglo XIX, la rodearán para cercarla desde todos los flancos posibles. Los discursos del managment, del coaching, del

\footnotetext{
${ }^{458}$.Cfr, Foucault, Michel, El Nacimiento de la biopolítica, en: Foucault, Michel, Obras..., op. cit. p. 870.

${ }^{459}$ Para un resumen de éste tema, véase: Castro Gómez, Santiago, Historia de la gubernamentalidad. Razón de Estado, Liberalismo y Neoliberalismo en Michel Foucault, Siglo del Hombre Editores, Bogotá, 2010, p. 178ss.
} 
emprendedurismo, del capital humano, ${ }^{460}$ cimentaran las bases de una especie de antropología empresarial ${ }^{461}$ en la cual el trabajador deberá reconocerse. De esta forma, un nuevo dispositivo, con sus propios saberes, sus propias estrategias y sus propias formas de gobierno, comenzará a consolidarse alrededor del mundo del trabajo.

${ }^{460}$ La teoría del "capital humano" surgida en la década de 1970. Los integrantes de la economía del desarrollo se valieron de este concepto para dar cuenta de la diferencia de productividad entre distintos grupos de trabajadores en función de su capacitación. Así, el capital humano caracterizaba un factor cualitativo que explica el mejor rendimiento laboral de los sectores con mayor formación. A partir de esta definición técnica, el término fue utilizado para mostrar la relación directa entre el salario y la formación personal, de donde se deduce que la causa de los bajos ingresos obedece a un déficit de inversión en el factor capital humano. Esta afirmación, más o menos cierta en circunstancias muy específicas, ha terminado por generalizarse para sostener que el capitalismo avanza hacia sociedades integradas por trabajadores muy bien calificados con generosos salarios producto de su eficiencia productiva. Este concepto trajo consigo un reacomodo epistemológico en el marco de las posturas vinculadas al neoliberalismo. Para la teoría del "capital humano" el hombre es un empresario de sí mismo capaz de invertir en su propia capacitación, con ello puede diferenciar y potenciar la calidad de su trabajo haciéndose más competitivo hasta alcanzar un salario compatible con su nivel de productividad. Los neoliberales norteamericanos creen que el trabajo indiferenciado que caracterizó al capitalismo del siglo XIX y de la primera mitad del XX, no es inherente a la dinámica del capital; es, por el contrario, la consecuencia obligada de no haber generado una teoría que concibiera al hombre como un agente capaz de modificarse a sí mismo para hacerse más productivo y valioso en el mercado.

${ }^{461}$ (Lemke,...op.cit.) 


\section{Anexo: Cuestiones de método}

Michel Foucault llamó genealogía a aquel procedimiento analítico que pretendía dar cuenta de las condiciones, a la vez discursivas y prácticas, que hacen posible la aparición de un problema para el pensamiento en un momento dado y bajo circunstancias específicas. En particular, el francés mostró con solvencia que la aparición de ciertos focos de experiencia cuya dinámica interna está atravesada por prácticas de gobierno, no puede ser estudiada en la clave de una racionalización progresiva y teleológica. ${ }^{462}$ De ahí que, desde su perspectiva, la comprensión de ciertas experiencias particulares requería tomar en cuenta las condiciones que hacen posible tanto su emergencia en el horizonte del pensamiento, como la coherencia interna de su funcionamiento. Así, con el término de dispositivo, Foucault hizo referencia al conjunto de discursos y prácticas racionalmente vinculados que le otorgan coherencia a un foco de experiencia singular donde tienen lugar prácticas de gobierno sobre algunos sujetos. Sin embargo, este proyecto teórico suponía un conjunto de apuestas filosóficas extremadamente precisas.

Fuertemente influenciado por los trabajos de Georges Canguilhem, Foucault se situó en aquellas coordenadas intelectuales en las cuales la epistemología terminaba por cruzarse con la historia. En efecto, como historiador de los conceptos, Canguilhem había tratado de mostrar las escansiones existentes en el interior de la historia de las ciencias para desautorizar un modelo analítico que daba soporte a ciertas concepciones filosóficas. Según este modelo, la historia de las ciencias podía leerse como el desarrollo de una racionalidad creciente y uniforme cuyo progreso era el resultado de paulatinas conquistas por parte del conocimiento. ${ }^{463}$ Frente a ello, el autor de Lo normal y lo patológico, buscaba mostrar la historia de las reglas que permiten que un concepto adquiriera sentido en el interior de un

\footnotetext{
462 "La arqueología -afirma Foucault- no trata de volver a encontrar la transición continua e insensible qe une, en suave declive, los discursos con aquello que los precede, los rodea o los sigue. No acecha el momento en el que, a partir de lo que no eran todavía, se han convertido en lo que son; ni tampoco el momento en que, desenlazando la solidez de su figura, van a perder poco a poco su identidad. Su problema es, por el contrario, definir los discursos en su especificidad; mostrar en qué el juego de reglas que ponen es irreductible a cualquier otro” Foucault, Michel, La arqueología del saber, Siglo XXI, México, 2007., p.234.

${ }^{463}$ En La arqueología del saber Foucault se refiere a Canguilhem de la siguiente manera: "Desplazamientos y transformaciones de los conceptos: los análisis de G.Canguilhem pueden servir de modelos. Mientras que la historia de un concepto no es, en todo y por todo, la de su acendramiento progresivo, de su racionalidad sin cesar creciente, de su gradiente de abstracción, sino la de sus diversos campos de constitución y de validez, la de sus reglas sucesivas de uso, de los medios teóricos múltiples donde su elaboración se ha realizado y acabado". Ibid, p.7.
} 
discurso científico luego de constantes modificaciones, reacomodos, correcciones y recomposiciones tanto de sus objetos, como de sus problemas. ${ }^{464}$

Sin embargo, a Foucault no le interesaba tanto analizar la forma en que se constituye la regularidad interna de una ciencia, como investigar aquello que le da sentido y coherencia a un conjunto de prácticas discusivas capaces de "formar grupos de objetos, conjuntos de enunciaciones, juegos de conceptos, series de elecciones teóricas”465. Así, de la misma manera que Canguilhem había refutado los supuestos teleológicos de los historiadores de las ciencias, Foucault intentaba mostrar las inconsistencias metodológicas de aquellos pensadores que intentaban poner en una relación de continuidad prácticas discursivas tan disímiles como, por ejemplo, aquellas que le otorgaban sentido a la Historia Natural y aquellas que le brindaban coherencia a la Biología, ${ }^{466} \mathrm{o}$, entre aquellas que se aglutinaban en la experiencia clásica de la locura y las que habían permitido la emergencia de la psiquiatría moderna.

Ahora bien, aunque el francés pretendía mostrar las discontinuidades existentes entre una práctica discursiva y otra evidenciando que sus conceptos, sus elecciones teóricas y la coherencia interna de sus objetos respondían a horizontes de problemas divergentes, su objetivo no consistía en distinguir aquellas prácticas legítimamente adscritas al registro de la ciencia de aquellas que pertenecían a un espacio no científico al que se podía calificar de ideológico. Ciertamente una distinción así era posible, pero no terminaba por dar cuenta de la singularidad de los objetos que Foucault quería analizar. De ahí que, en sus estudios sobre la mirada médica o la formación de las ciencias humanas, el filósofo francés utilizara el concepto de "saber" para establecer un espacio de análisis que no se limitaba a la distinción entre lo "científico" y lo "no científico". En el curso de 1981 titulado Du Gouvernement des vivants Foucault explicará claramente en qué consistió este desplazamiento:

La notion de savoir avait pour fonction, justement, de mettre hors champ l'opposition du scientifique et du non-scientifique, la question de l'illusion et de la réalite, la question du vrai et du faux. Non pas pour dire que ces oppositions n'avaient en tout état de cause ni sens ni valeur. -ce n'est pas ce que je voulais dire. Je voulais dire simplement qu'il s'agissait, avec le savoir, de poser le problème en termes de pratiques constitutives de domaines d'objets et

\footnotetext{
${ }^{464}$ Cfr, Canguilhem, Georges, Ideología y racionalidad en la historia delas ciencias de la vida, Amorrortu, Buenos Aires, 2005, pp.15ss.

${ }^{465}$ Foucault, Michel, La arqueología...,op.cit. p.305.

${ }^{466}$ Cfr, Foucault, Michel, Las palabras y las cosas, Siglo XXI, México
} 
de concepts à l'intérieur desquels les oppositions du scientifique et du non-scientifique, du vrai et du faux, de la réalité et d'illusion pouvaient prendre leurs effets. ${ }^{467}$

En realidad, Foucault intentaba tomar distancia del circulo althusseriano que entonces dominaba el panorama intelectual francés. Durante la década de los 1960 Louis Althusser había rehabilitado el concepto de ruptura epistemológica de Gastón Bachelard en el contexto de las disputas sobre la obra de Marx. ${ }^{468}$ De forma semejante a lo que Bachelard intentaba mostrar en el terreno de la historia de las ciencias, donde los conocimientos del sentido común son incompatibles a los descubrimientos científicos, Althusser buscaba evidenciar la distancia insalvable que existe entre a actividad científica desarrollada por Marx en El Capital y el carácter ideológico de sus escritos de juventud. Así, el autor de Pour Marx parecía sostener que era posible distinguir con relativa claridad cuándo un discurso dejaba de ser ideológico y se volvía científico. De esta manera, lo que Althusser denominaba práctica científica parecía ser interpretada como una actividad excluyente y de naturaleza distinta a la práctica ideológica. ${ }^{469}$

Sin negar por completo la distinción entre ciencia e ideología, Foucault intentaba habilitar una batería conceptual destinada a analizar un objeto distinto a aquel que Althusser había definido con el concepto de ideología. No se trataba ya de investigar las posibles rupturas entre lo científico y lo no científico, sino de comprender la conformación del espacio que permitía la emergencia misma de aquellos discursos sobre los que operaba esta

\footnotetext{
${ }^{467}$ Foucault, Michel, Du Gouvernement des vivants, Gallimard, Paris, 2012, p.13.

${ }^{468}$ Sobre las semejanzas y las diferencias en el uso del concepto de "corte epistemológico" entre Bachelard y Althusser véase: Balibar, Étienne, Escritos por Althusser, Nueva Visión, Buenos Aires, 2004.pp 9-49.

${ }^{469}$ A Foucault, en cambio, le parece que esta distinción excluyente entre ideología y ciencia resulta problemática pues nos obliga a encontrar el origen de esta diferencia, ya sea en el grado de adecuación a una estructura ideal que determinara a priori la forma de la ciencia, en la adecuada inadecuada utilización técnica de un discurso o, finalmente, en la propia conciencia de los sujetos. Hacia el final de La arqueología del saber Foucault trataba de mostrar que la diferencia entre lo que es o no ciencia siempre tenía lugar en el interior de una práctica discursiva común y no en una conciencia abstracta ajena al horizonte discursivo: "El sojuzgar de la ideología sobre el discurso científico y el funcionamiento ideológico de las ciencias no se articula al nivel de su estructura ideal (incluso si puede traducirse en él de una manera más o menos visible), ni al nivel de su utilización técnica en una sociedad (aunque pueda efectuarse), ni al nivel de la conciencia de los sujetos que la construyen, se articulan allí donde la ciencia se perfila con el saber. Si la cuestión de la ideología puede ser planteada a la ciencia, es en la medida que ésta, sin identificarse con el saber 'pero sin borrarlo ni excluirlo, se localiza en él [...] en la medida en que la ciencia se encuentra su lugar en una regularidad discursiva y en que, por ella, se despliega y funciona en todo un campo de prácticas discursivas o no. En suma la cuestión de la ideología planteada a la ciencia no es la cuestión de las situaciones o de las prácticas que releja de una manera más o menos consciente; no es tan poco la cuestión de su utilización eventual o de todos los malos usos que de ella se pueden hacer; es al cuestión de su existencia como práctica discursiva y de su funcionamiento entre otras prácticas” .Foucault, Michel, La arqueología...op.cit.pp.311-312.
} 
separación. La noción de saber, por tanto, daba cuenta de las condiciones de posibilidad de un conjunto coherente de enunciaciones sobre las cuales podían surgir distintos discursos, entre los cuales el discurso científico era una posibilidad.

Así, lo que el francés denominó arqueología del saber intentaba mostrar que las condiciones de posibilidad de ciertas enunciaciones con pretensión científicas particularmente en ciencias cuyo objeto era el hombre- no podían ser analizadas simplemente como el resultado de una racionalización progresiva; pero también, evidenciaba que las condiciones de posibilidad de dichas enunciaciones no sólo podían remitirse a las reglas internas de los discursos científicos sino a un espacio que las excedía, y, hasta cierto punto, explicaba la coherencia interna de sus problemas y sus objetos de estudio: "las ciencias señalaba Foucault- aparecen en el elemento de una formación discursiva y sobre un fondo de saber". 470

En retrospectiva, y despojado ya de todo ornamento estilístico, el énfasis que Foucault le otorgó a nociones como la de discontinuidad y saber, debe entenderse como una modesta precaución metodológica, un esfuerzo para enfrentar todo posible anacronismo y ahuyentar las confusiones más elementales. Como en su momento lo hiciera Canguilhem, Foucault trataba de luchar contra la perniciosa costumbre de abordar problemas existentes en focos de experiencia muy precisos desde coordenadas que no les correspondían. Pero también intentaba mostrar que los discursos de las ciencias siempre emergen en el marco de un conjunto de prácticas discursivas coherentes que pueden ser analizadas de forma rigurosa. No creemos equivocarnos si afirmamos que, por encima del énfasis circunstancial que Foucault colocó en otros tópicos, estas apuestas teóricas sostienen esa perspectiva epistemológica a la que Foucault denominó arqueología.

Ahora bien, la perspectiva arqueológica encontró su propia limitación en el concepto de saber. No tanto por su infertilidad, sino por su insuficiencia. En efecto, la emergencia de ciertos focos de experiencia no terminaba de ser comprendida si únicamente se apelaba a la formación de los discursos. De ahí que, desde los años 70’s, Foucault vinculará el análisis de las prácticas discursivas con el de ciertas tecnologías de poder. Su objetivo, era mostrar que la consistencia interna de ciertos discursos con pretensión de verdad no podía localizarse de forma exclusiva en el terreno del saber, sino que debía ser analizada en su relación con

${ }^{470}$ Ibid,p.308. 
prácticas de poder. Sin embargo, no se trataba de señalar que el poder era el sustrato último de cualquier fenómeno, sino de analizar experiencias muy concretas en las cuales la consistencia interna de los discursos sólo podía ser comprendida si se ponía en relación con prácticas que no necesariamente respondían a las reglas internas de una forma de saber.

Así, más que la noción de poder, la función asignada previamente a la noción de saber debía ser sustituida por una categoría capaz de dar cuenta de la articulación existente entre prácticas discursivas y mecanismos de poder. Una articulación que, a pesar de la heterogeneidad de sus elementos, mantenía una coherencia susceptible de análisis. La noción de dispositivo, utilizada por Foucault a mediados de la década de 1970, vino a cumplir este objetivo, tal como lo señalaba Foucault en una entrevista de 1977:

[...] ce que je voudrais repérer dans le dispositif, c'est justement la nature du lien qui peut exister entre [...] éléments hétérogènes. Ainsi, tel discours peut apparaître tantôt comme programme d'une institution, tantôt au contraire comme un élément qui permet de justifier et de masquer une pratique qui, elle, reste muette, ou fonctionner comme réinterprétation seconde de cette pratique, lui donner accès à un champ nouveau de rationalité. Bref, entre ces éléments, discursif ou non, il y a comme un jeu, des changements de position, des modifications de fonctions, qui peuvent, eux aussi, être très différents. ${ }^{471}$

Ahora bien, si la categoría de saber permitía tomar distancia de la separación entre ideología y ciencia en el plano epistemológico, el concepto de dispositivo servía para superar una insuficiencia política propia de la perspectiva althusseriana. En efecto, una vez que señalaba la distinción entre ideología y ciencia, el autor de Pour Marx avanzaba hacia una teoría social rudimentaria en la cual la existencia de un conjunto de ideas y prácticas articuladas de forma más o menos unificada por la clase dominante, configuraba el horizonte cotidiano de los sujetos en diferentes épocas de la historia. Así, con el concepto de "ideología dominante”, Althusser intentaba mostrar que las clases “poseedoras del poder” operaban mediante la unificación de un conjunto de ideas que encarnaban en el sentido común de los sujetos dominados a tal grado que éstos terminaban por aceptar su propia condición de sumisión:

Nous savons que cette idéologie dominante a pour fonction de permettre à la classe sociale qui a pris le pouvoir de l’Etat et qui exerce sa dictature, de devenir « dirigeante », c'est a dire de gagner la libre

\footnotetext{
${ }^{471}$ Foucault, Michel, Dits et écrits, Vol. II, Gallimard, Paris, 2001, p.266.
} 
consentement ( consensus) de ses exploites et domines en leur présentant une idéologie qui prévienne leur révolte et se les soumette volontairement. ${ }^{472}$

Ciertamente, la noción de ideología daba cuenta de una realidad social existente, sin embargo, al menos por dos razones, resultaba insuficiente para definir aquello que Foucault deseaba analizar. En primer lugar, como ya hemos visto, el presupuesto de una separación excluyente entre ideología y ciencia impedía el desarrollo de herramientas conceptuales capaces de mostrar que ciertos discursos de verdad pueden operar coherentemente al interior de sistemas de poder. El segundo motivo era más simple, la generalidad del concepto de ideología dominante resultaba demasiado amplia para estudiar realidades sumamente complejas y precisas como las que Foucault intentaba analizar:

[...] sous le mot « dominante » la notion d'idéologie dominante faisait l'impasse sur tous les mécanismes réels d'assujettissemment et elle se défaussait en quelque sorte de la carte, elle le repassait à une autre main, en disant : après tout, aux historiens de savoir comment et pourquoi certains dans une société dominent les autres. ${ }^{473}$

En cambio, la noción de dispositivo de saber-poder abría un campo de análisis imposible de asimilar por una categoría como la de ideología, bastante recurrente en los círculos marxistas. No se trataba, sin embargo, de negar la utilidad de ésta última de la misma sino de mostrar sus limitaciones y las posibilidades que se abrían al desarrollar un estudio minucioso de las formas de articulación entre discursos con pretensión de verdad y prácticas no discursivas en el marco de experiencias atravesadas por relaciones de poder.

Así el desplazamiento foucaultiano lo llevaba de una visión arqueológica centrada en las prácticas discursivas a una perspectiva genealógica enfocada en los dispositivos de saberpoder. Sin embargo, este último elemento -el poder- no dejó de generar confusiones a lo largo de la obra del francés. Sólo en 1978 el profesor del Collège de France logró delimitar con cierta claridad a qué se refería cuando utilizaba esa categoría:

[Le Pouvoir] n'est pas en lui-même une violence qui saurait parfois se cacher, ou un consentement qui, implicitement, se reconduirait. Il est un ensemble d'actions sur des actions possibles: Il opère sur le champ de possibilité où vient s’inscrire le comportement de sujets agissants: il incite, il induit, il détourne, il facilite ou rend plus difficile, il élargit ou il limite, il rend plus o moins probable; à la limite il contraint ou empêche absolument; mais il est bien

\footnotetext{
472 Althusser, Louis, Initiation à la philosophie pour les non-philosophes, P.U.F. Paris, 2014, p.329.

${ }^{473}$ Foucault, Michel, Du Gouvernemet...op.cit. p.13.
} 
toujours une manière d'agir sur un ou sur des sujets agissants [...] Le mode de relation propre au pouvoir ne serait donc pas à chercher du côté de la violence et de la lutte, ni du côté du contrat et du lien volontaire (qui ne peuvent en être tout au plus que des instruments): mais du côté de ce mode d'action singulier -ni guerrerier ni juridique qui est le gouvernement. ${ }^{474}$

En realidad, con la definición del poder en términos de gobierno, Foucault realizaba varias apuestas teóricas: en primer lugar, intentaba mostrar que las acciones que estructuran otras acciones no son exclusivas de un solo sujeto social, ya sea el soberano, el parlamento o la burguesía, sino que son el producto de la interacción de distintos sujetos en el marco de relaciones sociales precisas; también, deseaba señalar que el poder no se puede intercambiar como si fuera una sustancia, pues depende del ejercicio de una actividad más que de la posesión de cosas o cualidades; además, al concebir el poder como una acción sobre otras acciones, el francés buscaba escapar de una visión meramente negativa o coercitiva del mismo para mostrar que las acciones que se ejercen sobre los otros efectivamente pueden tomar la forma de la prohibición o la censura, pero también de la seducción o la inducción, pueden incitar ciertos actos, construir realidades, promover y delinear las estructuras de acción de los otros, producir discursos o apoyarse en ellos para orientar ciertas conductas, etc.

Esta particular definición del poder le permitía a Foucault dejar claro que, en tanto análisis de los dispositivos de saber-poder, el trabajo genealógico no debía entenderse como una especie de coartada para negar cualquier fundamento normativo, sino como una herramienta precisa para estudiar las condiciones que hacen posible aquellas experiencias específicas donde no sólo se requiere el uso de la fuerza, sino un conjunto de elementos entrelazados y referidos a saberes coherentes para estructurar la acción de unos sujetos con el fin de conducirla hacia ciertos fines. ${ }^{475}$ En otras palabras, un análisis genealógico implica

\footnotetext{
${ }^{474}$ Foucault, Michel, Dits...op.cit. p.1055. Tres elementos llaman la atención en esta definición. En primer lugar, Foucault señala explícitamente que el poder no debe abordarse ni por el lado de la violencia (en términos bélicos), ni por el lado del acuerdo (en términos contractuales). Llama la atención, en segundo lugar, que para definir un concepto tan importante en su obra, el francés recurra a una noción hasta ese momento inexplorada por él, nos referimos, por supuesto, a la noción de gobierno. Por último, resulta curioso que Foucault defina el poder como "una forma de actuar sobre la acción” de otros sujetos. Estos tres elementos son indisociables y constituyen las bases de un reacomodo conceptual y metodológico de altas repercusiones en el trabajo foucaultiano. Un reacomodo por medio del cual Foucault se desplaza de la forma, un tanto vaga, en la utilizó la noción de poder en la primera mitad de la década de 1970 y a la cual continuamente se hace referencia cuando se critica al francés.

${ }^{475}$ De ahí que resulten enteramente erróneas las críticas a Foucault según las cuales su noción del poder inhibiría cualquier espacio para la aparición de la razón. Se ve con claridad que la definición de poder como gobierno está lejos de apelar a una fuerza irracional que determina el desarrollo de las relaciones sociales
} 
un estudios de las “prácticas”" 476 discursivas y no discursivas que, en el marco de un proyecto racionalmente establecido, logran construir un sistema relativamente coherente destinado a producir efectos en la conducta de los hombres. ${ }^{477}$

independientemente de los sujetos (Cfr. Couzens, Hoy, et.al; Foucault, Nueva Visión, Buenos Aires, 1988, p. 71ss.); todo lo contrario, las relaciones de poder son el producto directo de la actividad humana y esa actividad siempre está mediada por la razón. Así, queda claro que, para el francés, el poder no es independiente de la razón y la razón no es independiente del poder.

${ }^{476}$ La racionalidad inmanente a la conducción de ciertos actores sociales no puede localizarse en alguna estructura fundamenta del sujeto, de ahí que se gané muy poco partiendo de la conciencia humana o explorando los recónditos intersticios de su psique, resulta mucho más fértil tomar como objeto de análisis las prácticas, como señala Foucault: "De esto se sigue un tercer principio de método: el de dirigirse como dominio de análisis a las prácticas, y abordar el estudio por el sesgo de lo que se hace.” (Foucault, Michel, Obras...p. 1002).

477 Como afirma Fréderic Gros, la noción de gobierno permite que Foucault le otorgue un estatuto activo tanto a los saberes como a los sujetos. En ese sentido, los estudios de Foucault no serían tanto estudios sobre el poder como análisis sobre la: "[...] articulación entre formas de saber, relaciones de poder y procesos de subjetivación, que son planos distintos. Se establece un gobierno sobre sujetos y con la ayuda de saberes". (Gros, Fréderic, Foucault, Amorrortu, Buenos Aires, 2007, p. 111). 


\section{Bibliografía}

Abendroth, Wolfgang, Historia del movimiento obrero en Europeo, Editorial Estelar, Barcelona, 1970

Alegre, Luis; Fernández, Carlos, El orden de El Capital, Akal, Madrid, 2010.

Althusser, Louis, Initiation à la philosophie pour les non-philosophes, P.U.F. Paris, 2014.

Arendt, Hannah, Sobre la Revolución, Alianza, Madrid, 2006.

Arrighi, Giovanni, Adam Smith en Pekin, Akal, Madrid, 2007. , El largo siglo XX, Akal, Madrid, 2012

Audier, Serge, Néo-liberalisme(s), une archéoogie intelectuelle, Bernard Grasset, Paris, 2012

Balibar, Étienne, Escritos por Althusser, Nueva Visión, Buenos Aires, 2004.

Bastiat, Fréderic, Euvres économiques, PUF, Paris, 1983.

Blanc, Louis, Organisation du travail, Au Bureau de la Société de l'industrie fraternelle, París, 1847.

Blanqui, Louis Auguste, Euvres I. Des origines à la Révolution de 1848, Presses Universitaires de Nancy, 1993, p.253.

Bertomeu, María Julia, et.al. (comp.) Republicanismo y democracia, Miño y Dávila editores, Buenos Aires 2004.

Bidet, Jacques, Theoríe de la modenité, PUF, Paris, 1990.

, Explication et reconstruction du capital., PUF, Paris, 2001.

, Bidet, Jacques, Le neo-libéralisme. Un autre grand récit, Les Praires

Ordinaires, Paris, 2016.

Boltansky, Luc; Ève Chiapello, El nuevo espíritu del capitalismo, Akal, Madrid, 2002.

Boron, Atilio, La filosofía política: De Hobbes a Marx, CLACSO, Buenos Aires, 2000.

Bouloiseau, Marc, La República jacobina. 10 de agosto 1792-9 de termidor año II, Ariel, Barcelona, 1980.

Butler, Judith, El género en disputa, Paidos, Barcelona, 2007.

Canguilhem, Georges, Ideología y racionalidad en la historia de las ciencias de la vida, Amorrortu, Buenos Aires, 2005.

Lo normal y lo patológico, SXXI, México, 1978.

Cárdenas, Enrique, El largo curso de la economía mexicana, FCE, México, 2015.

Castel, Robert, El ascenso de la incertidumbre, Fondo de Cultura Económica, México, 2010. 
, La metamorfosis de la cuestión social. Una crónica del salariado. Paidos,

Barcelona, 1997.

, La inseguridad social. ¿Qué es estar protegido?, Manantial, Buenos Aires,

2015.

Castro Gómez, Santiago, Historia de la gubernamentalidad. Razón de Estado, Liberalismo

y Neoliberalismo en Michel Foucault, Siglo del Hombre Editores, Bogotá, 2010

Conchon, Anne, “Le travail entre labeur et valeur: la corvée royale au XVIIIe siècle”, en:

Cahiers d'histoire, consultado el 21/02/2016 en: https://chrhc.revues.org/1973

Constant, Benjamin, Écrits politiques, Gallimard, Paris, 1997.

, Principes de politique, Chez Alexis Eymeri, Paris, 1815

Cordera, Rolando; Ramírez, Kuri; Ziccardi, Alicia, (coomp.), Pobreza, desigualdad y exclusión social en la ciudad del siglo XXI, Siglo XXI, México, 2012.

Couzens, David, (comp.), Foucault, Nueva visión, Buenos Aires, 1988.

Davidson, Arnold, La aparición de la sexualidad, Alpha Decay, Barcelona, 2004.

Davidson, Neil, Transformar el mundo, Ediciones Pasado y Presente, Barcelona, 2013.

Dobb, Maurice, Las teorías del plusvalor de Smith a Marshal, Siglo XXI, México, 2004.

Domènech, Antoni, El eclipse de la fraternidad, Crítica, Barcelona, 2004.

Donzelot, Jacques, La invención de lo social, Nueva visión, Buenos Aires, 2007.

Engels, Friedrich. La situación de la clase obrera en Inglaterra, Buenos Aires, Editorial

Futuro, 1965.

Escalante, Fernando, Historia mínima del neoliberalismo, El Colegio de México, México, 2015.

Ewald, François, L'Etat providence, Grasset, Paris, 1986,

Faulstich, Werner; Korte, Helmut (coomp.), Cien años de cine, 1925-1944, SXXI, México, 1995.

Faure, Alain et Rancière, Jacques, La parole ouvrière, La fabrique, Paris, 2009.

Fontaine, Arturo, “Selección de escritos de Edmund Burke”, en: Estudios Públicos, N9, Chile, 1993.

Foucault, Michel, Dit et écrits II. 1976-1988, Gallimard, Paris, 2001.

, Du Gouvernement des vivants, Gallimard, Paris, 2012.

, Historia de la locura en la época clásica I, FCE, México, 2006. 
, La arqueología del saber, SXXI, México, 2007.

, Las palabras y las cosas, SXXI, México, 2007.

, La Société punitive, Gallimard, Pris, 2013.

, Obras esenciales, Paidós, Barcelona, 2010.

, Vigilar y castigar, Siglo XXI, México,2009.

Fukuyama, Francis, El fin de la historia y el último hombre, Planeta, Madrid, 1992.

Gauthier, Florence, Triomphe et mort de la Révolution des droits de l'homme et du citoyen, Syllepse, Paris, 2009.

, “Soberanía, república, democracia y derechos son bienes comunes de todos los hombres libres” Consultado el: 29/07/2015 en:

Gonzáles, Jesús, “Libertad, igualdad, fraternidad en el socialismo jacobino” en: Anuario de Filosofía del Derecho, Madrid, 1989.

Greblo, Edoardo, Democracia, Nueva Visión, Buenos Aires 2002.

Gros, Fréderic, Foucault, Amorrortu, Buenos Aires, 2007.

Harsin, Jill, Barricades. The War of the streets in Revolutionary Paris, 1830-1848, Palgrave, Nueva York, 2002.

Harvey, David, Breve historia del neoliberalismo, Akal, Madrid, 2010.

, La condición de la posmodernidad, Amorrortu, Buenos Aires, 2004. , París, capital de la modernidad, Akal, Madrid, 2008.

Hegel, G.W.F. Principios de la filosofía del derecho, Edhasa, Barcelona, 1999.

Himmelfharb, Gertrude, La idea de la pobreza. Inglaterra en la época de la Revolución Industrial, FCE, México, 1989

Hobswan, Eric, La era del capital 1848-1875, Crítica, Barcelona, 2003. , La era de la Revolución 1789-1848, Crítica, Barcelona, 2003. , Los ecos de la marsellesa, Crítica, Barcelona, 1992.

Honneth, Axel, Lucha por el reconocimiento. Por una gramática moral de los conflictos sociales, Crítica, Barcelona,1997

Jordan, David. P., Robespierre. El primer revolucionario, Javier Vergara Editor, Buenos Aires, 1986.

Kant, Immanuel, En defensa de la Ilustración, Alba Editores, Barcelona, 1999. 
Keynes, John Maynard, Teoría general de la ocupación, el interés y el dinero, FCE, México, 2014.

Kicillof, Axel, Fundamentos de la Teoría General, Eudeba, Buenos Aires, 2007.

Lastra, José Manuel, “Las corporaciones de oficio y la libertad de asociación en Francia”, en: Revista de la Facultad de Derecho, UNAM, Número 223-224 Enero-Abril Año 1999.

Lemke, Thomas, Economy and Society, Volume 30, Number 2, May 2001. , et al, Marx y Foucault, Nueva Visión, Buenos Aires, 2006.

Leroux, Pierre, Aux philosophes, aux artistes, aux politiques. Trois discourses et autres textes, Éditions Payons \& Rivages, 1994.

Lessnof, Michael, La filosofía política del siglo XX, Akal, Madrid, 2011.

Lis, Catherine, Soly, Hugo, Pobreza y capitalismo en la Europa preindustrial (1350-1850), Akal. Madrid, 1982.

Locke, John, Segundo Tratado sobre el Gobierno Civil, Alianza, Madrid, 2004.

Losurdo, Doménico, Contrahistoria de liberalismo, El Viejo Topo, s/l, 2005.

Macpherson, C.B., La théorie politique de l'individualisme possessif. De Hobbes à Locke.

Gallimard, Paris, 2004

Malthus, T.R, Ensayo sobre el principio de la población, FCE, México,1986.

Marx, Karl, El Capital. Tomo I. Volúmen 1, Siglo XXI, México, 2013. , El Capital. Tomo I. Volúmen 2, Siglo XXI, México, 2013. , El Capital. Tomo I. Volúmen 3, Siglo XXI, México, 2013. , Teorías de la plusvalía II, FCE, México, 1980.

Marx, Karl; Engels, Friedrich, El manifiesto comunista, Fondo de Cultura Económica, México, 2007. , Los grandes fundamentos II, Fondo de Cultura Económica,

México, 1988. , Las Revoluciones de 1848, Fondo de Cultura Económica,

México, 1988. , Obras Escogidas I, Editorial Progreso, Moscú, 1977.

Mendez, Victor, El filósofo y el mercader. Filosofía, derecho y economía en la obra de Adam Smith, FCE, México, 2004. 
Molinari, Gustave, Las bourses de travail, Gullaumin, Paris, 1893.

Montesquieu, De l'esprit des lois, La Pléiade, Paris, 1951.

Morton. A.L.; Tate, George, Historia del movimiento obrero inglés, Editorial Fundamentos, Madrid, 1971.

Muniesa, Bernat, Libertad, liberalismo, democracia, El Viejo Topo, s/l, 2008.

Novelo, Federico, De Keynes a Keynes. La crisis económica global en perspectiva histórica, UAM, México, 2011.

Nozcik, Robert, Anarquía, Estado y utopía, FCE, México 1991.

Olivan, Irene, La Revolución Francesa (1789-1799), Editorial Síntesis, Madrid 1997.

Ovejero, Félix, Incluso un pueblo de demonios: democracia, liberalismo, republicanismo, Ed. Katz, Madrid, 2008.

Palmer, R \& Colton, J, Historia contemporánea, Akal, Madrid, 1971.

Peillon, Vincent, Pierre Leroux et le socialisme Républicain, Le bord de l'eau, Bordeux, 2003.

Piore, Sable \& Sabel, Charles, The Seconde Industrial Divide, Basic Books, New York,1984

Plamenatz, John, The Revolutionary Movement in France, 181-71, Lonmans, 1952.

Polanyi, Karl, La gran transformación, Juan Pablo Editor, México, 1975.

Pouthas, Carles; Guirald, Pierre; et al. Democracia, reacción, capitalismo (1848-1860), Akal, Madrid, 1993.

Poulantzas, Nicos: Estado, poder y socialismo, Siglo XXI, México, 1979.

Quesnay, François, Euvres complétés. Vol II. Institut National D’Études Démographiques, Paris, 1950

Procacci, Giuliano, Historia General del siglo XX, Crítica, Barcelona, 2005.

Ramos, Gorostiza, “Joseph Towsend y la cuestión de los pobres en la España Ilustrada” en: Hispanic enlightenment, Vol. 36, $\mathrm{N}^{\circ} 1,2013$

Rawls, Jhon, A Theory of justice, Oxford Univ. Press, Oxford, 1971.

Reyes Heroles, Jesús, El liberalismo mexicano I. Fondo de Cultura Económica, México, 2007.

Rémond, René, Les droites en France, Aubier Montaigne, 1982.

Renault, Mathieu, L'Amerique de John Locke. L'Expansion Coloniale de la Philosophie Européenne, Paris, Editions Amsterdam, 2014. 
Ricardo, David, Principios de economía política y Tributación

Robespierre, Maximilien, Discours sur la religión, la République , l'esclavage, Éditions de l'aube, s/l, 2013.

_, Euvres complètes, Paris, PUF/ Société des études robespierristes,

1950, vol VI.

, Euvres. Tome IX, Phénix Éditions, Paris, 2000.

, Por la felicidad y por la libertad. Discursos, El Viejo Topo, s/a,

$\mathrm{s} / \mathrm{l}$.

Roche, Claude, Le connaissance et la loi dans la pensée économique libérale, L'Harmattan, Paris, 1993

Roll, Eric, Historia de las doctrinas económicas, FCE, México, 1987.

Rosanvallon, Pierre, El capitalismo utópico, Nueva Visión, Buenos Aires, 2006,

Saint-Simon, Claude, Catecismo político de los industriales, Aguilar, México, 1964.

Salazar, Luis, Para pensar la política, UAM, México, 2004.

Sassen, Saskia, Territorio, autoridad y derechos: de los ensamblajes medievales a los ensamblajes globales, Katz, Madrid, 2010.

Say, Jean Baptiste, Tratado de Economía Política de economía política, Fondo de Cultura Económica, México, 2001.

, Say, Jean Baptiste, Collection de Principaux Economistes,

Osnabrück, s/l,1966.

Schelle, Gustav, Oeuvres de Turgot et documents le concernant, verlag de detley auverman

KG, París, 1973.

Senior, Nassau, William, "Causas y soluciones de los disturbios presentes" en Textos Selectos

de Grandes Economistas accesible libremente en www.eumed.net/textos/

Senneth, Richard, La corrosión de carácter, Anagrama, Barcelona, 2010.

Sewell, William, Trabajo y revolución en Francia. El lenguaje del movimiento obrero en

Francia desde el Antiguo Régimen hasta 1848, Taurus, Madrid, 1992.

Sieyès, Emmanuel, Escritos y discursos de la Revolución, Centro de Estudios Políticos y

Constitucionales, Madrid, 2007.

Skidelsky, Robert, El regreso de Keynes, Crítica, Barcelona, 2009. 
Smith, Adam. Investigación acerca de la naturaleza y causas de la riqueza de las naciones, FCE, México, 2006.

Soboul, Albert, Revolución Francesa, Tecnos, Madrid, 1983.

Solis, Leopoldo, La herencia intelectual de John Maynard Keynes, El Colegio Nacional, México, 1987.

Thompson, E.P. La formación de la clase obrera. Tomo I. Crítica, Barcelona, 1989.

Tocqueville, Alexis, El Antiguo Régimen y la Revolución, Alianza, Madrid, , Contre le droit au travail, les belles lettres, Paris, 2015. , Lettres choisies. Souvenirs, Gallimard, París, 2003

Tully, James, An aprroach to political philosophy: Locke in contexts, Cambridge University Press, Great Britain, 1993

Vigier, Philippe, La Seconde République, PUF, Paris, 2001

Várnagy, Tomás, “El pensamiento político de Jhon Locke y el surgimiento del liberalismo”, en: Boron, Agilio, La filosofía política: De Hobbes a Marx, CLACSO, Buenos Aires, 2000. Wallerstein, Immanuel, El moderno sistema mundial IV. El triunfo del liberaismo centrista 1789-1914 Alianza, México, 2014.

Wollen, Peter, El asalto a la nevera, Akal, Madrid, 2006.

Zola, Émile, Germinal, Gernika, México, 2011. 
POBRES LABORIOSOS. UNA GENEALOGIA DEL TRABAJO EN EL DISPOSITIVO LIBERAI

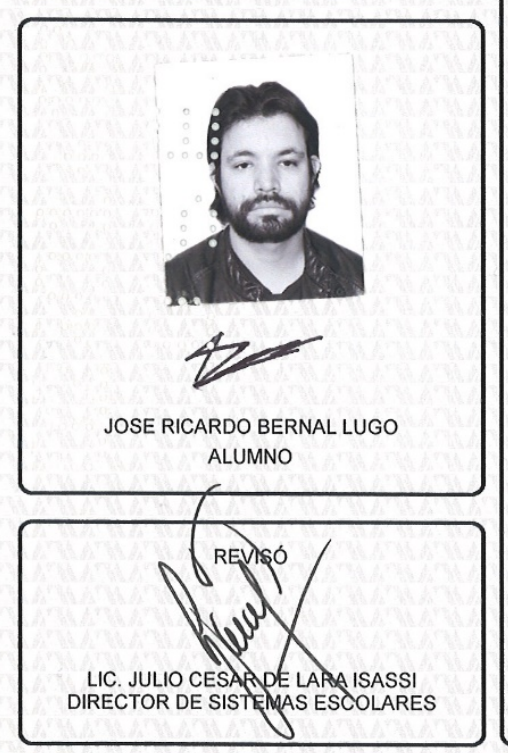

Bajo la Presidencia del primero y con carácter de Secretario el último, se reunieron a la presentación de la Disertación Pública cuya denominación aparece al margen, para la obtención del grado de:

DOCTOR EN HUMANIDADES (FILOSOFIA)

DE: JOSE RICARDO BERNAL LUGO

y de acuerdo con el artículo 78 fracción IV del Reglamento de Estudios Superiores de la Universidad Autónoma Metropolitana, los miembros del jurado resolvieron:

\section{APROBAR}

Acto continuo, el presidente del jurado comunicó al interesado el resultado de la evaluación y, en caso aprobatorio, le fue tomada la protesta.
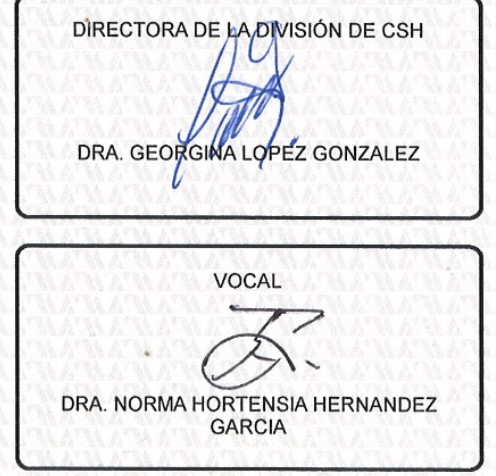

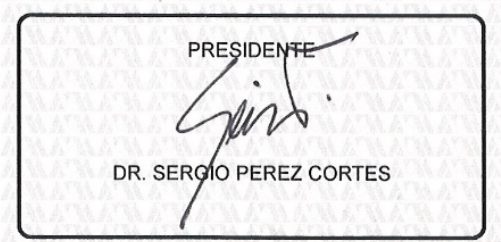

SECRETARIO

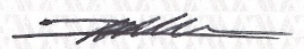

DR. DONOVAN ADRIAN HERNANDEZ CASTELLANOS 